UNIVERSIDADE DE SÃO PAULO

FACULDADE DE FILOSOFIA LETRAS E CIÊNCIAS HUMANAS

DEPARTAMENTO DE LETRAS CLÁSSICAS E VERNÁCULAS

\title{
A argumentação no Exame Nacional do Ensino Médio/2004: \\ percursos discursivos seguidos por jovens em processo de formação
}

Isabel Cristina Michelan de Azevedo

Tese apresentada à Faculdade de Filosofia, Letras e Ciências Humanas da Universidade de São Paulo, Departamento de Letras Clássicas e Vernáculas, Área de Filologia e Língua Portuguesa, para obtenção do título de Doutor em Letras.

Área de concentração: Estudos do Discurso em Língua Portuguesa - Retórica e Argumentação

Orientador: $\operatorname{Prof}^{\mathrm{a}} \mathrm{Dr}^{\mathrm{a}}$ Lineide do Lago Salvador Mosca

ANÁLISES DE TEXTOS

v.2

São Paulo

2009 


\section{APRESENTAÇÃO}

Se tratarmos as pessoas como elas devem ser, nós as ajudamos a se tornarem o que elas são capazes de ser.

Goethe

Ao tomarmos o texto como um artefato linguístico e como produto/processo sociocultural, propomo-nos a conciliar uma abordagem mais formalista, que lida com os elementos constitutivos dos textos, enquanto artefatos e construtos, com uma abordagem sociointeracionista do fenômeno linguístico, que enfatiza as condições de produção, os modos de distribuição das informações e a interdependência do eu em relação ao outro por meio dos textos construídos.

Acompanhar o movimento contínuo de contextualização/recontextualização dos textos é uma maneira de mapear os processos de elaboração do pensamento e dos discursos e, ao mesmo tempo, de observar os mecanismos de circulação das produções verbais.

Enquanto fenômeno linguístico estruturado e orientado para o estabelecimento de relações de sentido, o texto conjuga diferentes elementos, exigindo, dessa forma, um olhar específico do pesquisador para as características formais empregadas (ou não), e também um olhar mais amplo voltado para a variedade de interações sociais estabelecidas entre os interlocutores (concretos ou distantes) do discurso.

Assim sendo, o texto se configura como um sistema de atividades e de operações, cuja estrutura revela um número aberto de variáveis e um repertório fechado de regras, socialmente aceitas (embora nem sempre de acordo com a língua padrão), direcionado a intencionalidades específicas. 
Essa perspectiva alinha-se ao conceito de textualidade, elaborado por Beaugrande e Dressler (1981), que o definem como princípio organizacional e comunicativo do texto, ao mesmo tempo em que destaca a constituição do texto como um acontecimento discursivo.

Segundo esses autores, a textualidade é composta por sete fatores - coesão, coerência, intencionalidade, informatividade, aceitabilidade, situacionalidade e intertextualidade - que permitem identificar as condições para uma ação linguística, cognitiva e social na qual eles operam como modos de conectividade em níveis diversos, mas inter-relacionados.

Já a noção de acontecimento discursivo está associada ao momento em que as posições dos sujeitos se configuram seja pela aceitação de uma formação discursiva ou pelo confronto de ordens diferentes do discurso.

Nos textos que passaremos a analisar, de acordo com as orientações de Charolles, buscaremos evidenciar como a análise, segundo a linguística textual, pode favorecer a compreensão das estratégias de defesa de ideias próprias de textos argumentativos e se os mecanismos enunciativos selecionados contribuem efetivamente para a persuasão do leitor em relação aos pontos de vista apresentados.

Como a escrita é concebida aqui como o produto de toda uma série de componentes, identificar a maneira como eles se organizam, recombinam, articulam, estabelecem sentidos e significados permitirá perceber o quanto favorecem a composição das justificativas, a tomada de defesa, a formulação de hipóteses e a apresentação de uma síntese pessoal final.

Esperamos, com isso, mostrar que a aprendizagem da argumentação escrita pode conduzir os alunos a uma leitura e produção textual mais qualificada, pois serão capazes de reconhecer o valor da escolha e a disposição dos argumentos, da adaptação do discurso ao interlocutor e da aplicação de diferentes recursos argumentativos em prol da persuasão do outro. 


\section{Redações}

\section{4-6}

Os meios comunicativos tem por direito o uso da liberdade de expressão, mas a manutenção e o bom uso são essenciais para não ocorrer abuso, deve haver concientização e respeito dos valores sociais, pois estão em jogo, a moral e a ética da população.

As formas de liberdade chegam na maioria das vezes a desrespeitar o que também é de direito do povo, ocorre então, um abuso ocasionado do uso indevido da liberdade.

As pessoas que assistem, observam atentamente as notícias geradas, mortes, acusações, estupros, violência generalizada, o que alimenta os valores televisivos de busca a mostrar o que o povo quer ver. Sem perceber estão tirando a liberdade de outros, não consultam as famílias, pessoas ligadas aos fatos, apenas mostram, e fazem algo normal, visto por todos mais sem grandes espantos.

A questão principal é o bom-senso por parte dos envolvidos, é claro que a criação de um órgão não-governamental, neutro e imparcial, é imprescindível para reestruturar e manter a ordem do sistema comunicativo, isso os tornaria não tão abusivos e quem sabe até melhores.

O certo é que a reestruturação levaria a uma utilização sem abusos, sem ferir a moralidade social, com os meios de comunicação controlados contra possíveis abusos a população recebe seu direito de liberdade com maior efetividade.

\section{ANÁLISE}

Tendo como base os pressupostos teóricos determinados para a realização da análise da produção textual foi possível verificar, primeiramente, que o restrito conhecimento de mundo do autor interferiu de forma marcante na elaboração do texto, visto que a dificuldade argumentativa associada à desorganização de ideias culminou na construção de parágrafos desconexos que expõem pensamentos contraditórios, corroborando a falta de coesão e coerência do texto.

Uma análise superficial do texto revela problemas como o uso restrito de elementos de coesão textual, grande repetição de vocábulos devido à pobreza vocabular, pouco conhecimento do tema abordado e dificuldades em relação à estruturação do texto escrito.

O posicionamento ideológico do autor apresenta incoerências argumentativas, principalmente quando generaliza afirmações que posteriormente são refutadas no decorrer do 
processo dissertativo, ocasionando dificuldades interpretativas para o leitor apreender o real sentido do texto.

O uso da expressão "meios comunicativos", no primeiro parágrafo, é generalizante demais por abarcar uma quantidade muito grande de processos comunicativos, como a fala, a escrita e as linguagens não-verbais, quando o autor queria referir-se apenas aos meios de comunicação de massa como a televisão e o jornal.

O redator não deixou muito claro o quis dizer com o termo "manutenção" (como fazer a manutenção da liberdade?), afinal não há exemplos ou esclarecimento posterior, o que nos remete a uma falha com relação à metarregra número 1 (repetição), já que ele não retoma as ideias explícitas.

Logo em seguida, é mencionado o "bom uso" dos meios de comunicação, mas o que seria esse bom uso? Também não encontramos exemplos.

Ainda no primeiro parágrafo, apontamos uma falha com relação à coesão sequencial de que fala Koch, pois não há conectivo entre as orações: “[...] são essenciais para não ocorrer abuso" e "deve haver conscientização [...]". No entanto, verifica-se, também, o uso correto desse recurso com os conectivos "mas" e "pois" no mesmo parágrafo.

É importante verificar que o segundo parágrafo não progride em termos argumentativos, haja vista a reiteração de conceitos já mencionados que nada acrescentam de novo. Neste caso, o uso da repetição com objetivo de retomar e fazer a manutenção da mesma sequência temática parece ter empobrecido o texto. Também neste momento, temos a repetição de unidades do léxico (abuso, uso, respeito, desrespeito, liberdade) com o propósito de enfatizar a sua opinião a respeito do assunto, mas esse objetivo também não foi alcançado devido à falta de argumentos, bem como clareza sobre o mote. No entanto, no mesmo parágrafo temos um bom exemplo de substituição lexical por sinônimo (população/povo).

Os exemplos das notícias do terceiro parágrafo poderiam servir de aposto, a fim de deixarem o texto mais claro, mas o uso indevido da pontuação não permitiu que isso ocorresse, ocasionando ambiguidade e até mesmo falta de clareza ao trecho. Após citar os exemplos, o autor menciona que estes "alimentam os valores televisivos". Quais seriam os valores televisivos? Não há exemplos concretos.

No trecho "[...] o que o povo quer ver", percebemos uma certa generalização que pode causar problemas com relação à aceitabilidade do texto pelo leitor (aceitabilidade de Beaugrande e Dressler).

Encontramos também problemas relacionados à metarregra número 3 (nãocontradição) no terceiro parágrafo. Quando o aluno expõe: “estão tirando a liberdade [...] não 
consultam [...]" e posteriormente menciona: "fazem algo normal". Tirar a liberdade, não consultar as famílias é algo normal? Há uma total contradição em relação ao que havia exposto antes.

Outra questão é levantada no quarto parágrafo. Poderia um órgão não-governamental reestruturar, ditar leis e regras a serem seguidas, efetivamente, pelo sistema comunicativo? Este parágrafo revela o pouco conhecimento do autor sobre o sistema governamental brasileiro e as regras que orientam a liberdade de imprensa no país.

No último parágrafo, também notamos uma grave contradição, ferindo, claramente, a coerência do texto. Quando menciona: “com os meios controlados [...]" e depois "a população recebe seu direito de liberdade". Como pode haver liberdade de acesso à informação se esta será controlada? Talvez se possa até compreender o objetivo do autor se lermos atentamente a passagem, mas notamos que a escolha indevida de vocábulos interfere no entendimento do texto.

Em suma, o autor repete as mesmas ideias em praticamente todo o texto e apesar de tentar propor uma alternativa para o problema, não o faz com propriedade. Pela leitura podemos inferir que não há um conhecimento de mundo suficiente para o aluno produzir um texto argumentativo de qualidade sobre o tema proposto.

O texto apresenta em toda a sua extensão lacunas textuais, que mesmo complementadas pela ação interpretativa do leitor, dificultam o entendimento do texto. Revelam-se, pois, problemas com relação ao domínio de habilidades de leitura e escrita por parte do autor, além do pouco domínio da estrutura do texto escrito.

\section{5-4}

Com as pessoas sabem que existe uma lei que proteger elas do abuso do meio de comunicação e qualquer informação que ela tinha dado aos meios a comunicação elas deveriam conhecer os direitos.

E com o conhecimento das pessoas as empresa de comunicação ficariam menos poderosa quando qualquer pessoa fosse reclama que o meio de comunicação tinham colocado informação a mais.

E também gostaria que os meios de comunicação coloca-se informação verdadeira para as pessoas que existem e escutam o que eles falam. 


\begin{abstract}
ANÁLISE
De maneira global, percebemos de imediato que o produtor desta redação não consegue expressar satisfatoriamente suas ideias, e desta forma ocorre uma precária articulação e organização.

O texto nos impressiona antes mesmo de uma análise mais aprofundada, tendo em vista que há uma extrema dificuldade do aluno em utilizar aceitavelmente a modalidade escrita da língua portuguesa.

Os desvios em nível formal, especialmente aos que se referem à ortografia e pontuação são graves. Além disso, são nítidos os problemas no aspecto lógico-semântico.

Não há articulação entre o texto e o tema proposto. Desta forma, fica clara a infração à metarregra de relação (MR4).

O hábito da oralidade é constante e não há uma preocupação por parte do autor com a revisão do texto, pois percebemos que ele começa e não termina as ideias, bem como as palavras.

Encontramos também a repetição lexical de "meios de comunicação", não como forma de reiteração de ideias, mas como falta delas.

No primeiro parágrafo, notamos a repetição tripla do pronome pessoal "ela(s)", pronominalização característica da metarregra 1 que foi pouco efetiva, já que acabou por deixar o texto ainda mais confuso. Apesar de os referentes terem sido expressos, a falta de conexões entre as ideias possibilitou essa confusão.

Embora seja um texto em que predomine a incoerência e a falta de organicidade, devemos citar o exemplo do último parágrafo, o qual fere a terceira metarregra. Como menciona Costa Val, há uma contradição externa no momento em que o produtor menciona: "gostaria que os meios de comunicação coloca-se informação verdadeira para as pessoas que existem e escutam o que eles falam", ferindo um princípio lógico e, por que não, contradizendo o mundo real. Como poderiam os meios de comunicação transmitir informações a pessoas que não existem?

Em síntese, o texto apresenta sérios problemas de coerência que, segundo as metarregras de Charolles, repercutem na estruturação deficiente do conteúdo. O mote da proposta não é desenvolvido com consciência e serenidade.
\end{abstract}




\section{1-6}

\section{Como garantir a liberdade de informação e evitar abusos nos meios de comunicação?}

\section{Informação para um futuro melhor}

A liberdade de informação hoje, é uma coisa que deve ser levada muito a séria, principalmente no Brasil. Onde os índices de violência, desemprego e analfabetismo são assustadores. E a mídia, de uma certa forma não contribui para que as pessoas edifiquem suas mentes em coisas boas e agradáveis.

Quando ligamos nossos aparelhos de rádio e televisão, podemos notar que a maioria das informações repassadas aos ouvintes e telespectadores não são de grandes utilidades. E o que precisamos, hoje é de informações e notícias que nos preparem para um futuro mais organizado.

Assim sendo, para estes e outros problemas que enfrentamos não só no Brasil, mas em outros países. Os governos deveriam adotar propostas que se encaixassem às propostas lançadas pela mídia, para que não haja mais esses "abusos" que vemos todo santo dia em nossos lares. É que a mídia de forma geral, não pense somente no lucro que vão receber com programas de rádio e televisão "baratos", mas que pensem em repassar ao público notícias de grande importância para a formação e o caráter de cada ouvinte e telespectador.

\section{ANÁLISE}

No primeiro parágrafo, notamos o uso inadequado da pontuação. Poderíamos até citar neste caso o uso correto da substituição gramatical (Brasil retomado pelo advérbio onde), se a pontuação não a tivesse prejudicado.

Percebemos uma tentativa de uso de um vocabulário mais elaborado, no entanto, o produtor peca por não ter uma real clareza do significado do vocábulo: "a mídia, de uma certa forma não contribui para que as pessoas edifiquem suas mentes em coisas boas e agradáveis" (grifo nosso).

Além disso, nota-se que em vários momentos o autor não tem lucidez sobre o que escreve, por exemplo, quando diz: "o que precisamos, hoje é de informações e notícias que 
nos preparem para um futuro mais organizado" (grifo nosso) ${ }^{1}$. O que seria um futuro mais organizado?

No segundo parágrafo, o autor menciona que: "o que precisamos, hoje é de informações e notícias que nos preparem", mas somente a mudança de notícias veiculadas pelos meios de comunicação possibilita ou prepara para um futuro diferente? Vemos também nesse momento um tipo de generalização. Não há progressão.

Notamos que no terceiro parágrafo o aluno faz a tentativa de relacionar os fatos ao que já havia expressado (MR1) através da pronominalização (este), apesar de o referente se encontrar, de certa forma, distante. Apesar disso, não há progressão e conexão das ideias (MR2-MR4).

A pontuação inadequada interfere nos aspectos da textualidade, embora entendamos o que o aluno pretendeu dizer.

Mais uma vez, a falta de conhecimento do assunto culminou nas repetições lexicais MR1 (unidades da gramática: verbo repassar; e unidades lexicais: substantivos - ouvintes, telespectador e notícias) que não atingiram o objetivo da continuidade e sim foram empregados por mera falta de ideias.

Na conclusão, a proposta que o autor faz é sem fundamento (poderia exemplificar que tipo de propostas). As ideias são bastante simplistas.

\section{4-0}

\section{Como garantir a liberdade de informação e evitar abusos nos meios de comunicação?}

\section{Respeito}

Acima de tudo na vida esta o respeito. Todos temos o direito de dizer o que pensamos e o que sabemos, mas para levarmos o que sabemos para o meio que comunicação temos que saber ser a informação tem realmente algo de verdade, não passa apenas de um boato que começou sem nenhuma finalidade. Saber se a pessoa autoriza a informação a ser divulgada, é excensial para que não haja abuso.

\footnotetext{
${ }^{1}$ Todos os grifos subsequentes são nossos.
} 
Muitos falam, divulgam, criticam, se nem ao menos saber se é verdade, invadem privacidade sem nem ao menos pedir licença, sem se importar se pessoas irão perder o respeito do próximo, sem dar o direito para que possam se defender.

Todos queremos ficar bem informados, com boas noticias ou até mesmo com más noticias mas que sejam verdadeiras.

Porém todos na vida queremos respeito, mas temos que saber que antes de receber demos que da-lo, assim gostariamos de receber noticia com respeito de ambas as partes.

\begin{abstract}
ANÁLISE
Esse texto não apresenta, necessariamente, problemas para decodificação. Apesar de não seguir a estrutura dissertativa, o aluno expõe sua opinião a respeito dos abusos considerados mais importantes para ele. No entanto, não encontramos em nenhum momento uma proposta ou solução para o problema proposto.

Falta à redação uma introdução clara ao tema.

Encontramos, no segundo parágrafo, um paralelismo que parece enfatizar as ideias do primeiro. Além disso, esse recurso argumentativo estabelece certa harmonia ao texto, articulando-o e direcionando o leitor ao seu objetivo: "sem nem ao menos pedir licença, sem se importar se pessoas irão perder o respeito do próximo, sem dar o direito para que possam se defender".

O segundo parágrafo é praticamente igual ao primeiro, sendo que muitas informações são repetidas, por mera falta de ideias, configurando uma infração à MR2, tendo em vista que não há progressão no parágrafo.

Em suma, o texto apresenta muitas lacunas textuais, que mesmo complementadas pela ação interpretativa do leitor, dificultam o entendimento do texto. Revelam-se problemas com relação ao domínio de habilidades de leitura e escrita por parte do autor, além do pouco domínio da estrutura do texto escrito.
\end{abstract}




\section{0-2}

Nos proprios programas de televisão nos sofremos abusos, vendo e olvindo o que se falam, que voi estupro filha que filho matou pai e viceversa, os reporte ganhão para passar isso para nós, menten contan a verdade não sabemos, eles memos contem muitas violências para obter noticias.

Como garantir a liberdade, não dando informações erradas, nunca aconteceu nada comigo que eu pudesse esclarecer agora não eu vejo que varios artistas são pegos de surpresa com noticias que sai sobre eles, eu sei que os jornalistas precisam ganhar seu sustento mais contando mentiga com o nome dos outros. Porque não um trabalho honesto. Muitos casos que aparecem em são paulo entre policia e ladrão que não sabemos se é verdade eu é só uma armação eu sei que acontece mais todo dia, olha que macapá e violento mais eu não vejo tantas brigas será porque lá e maior dever ser mais e isso ou cada um com suas maneiras de dar informações para nois sejam mentiras ou verdade.

\section{ANÁLISE}

Fica claro nesse texto que o conhecimento de mundo do autor é bastante restrito. Os desvios à norma são gravíssimos, acrescidos à total falta de capacidade de concatenação das ideias.

Iniciamos, no primeiro parágrafo, com o comentário: "Nos proprios programas de televisão nos sofremos abusos, vendo e olvindo o que se falam, que voi estupro filha que filho matou pai e viceversa" De que forma sofremos abuso ao nos depararmos com tais notícias?

A infração à MR3 fica clara nas últimas orações do primeiro parágrafo: "eles memos contem muitas violências para obter noticias". É bem provável que o autor tenha querido dizer alguma outra informação, mas tornou seu texto bastante confuso ao colocar suas opiniões, afinal, os repórteres são violentos ou contam fatos violentos?

Quando o autor menciona "para obter notícias", não fica claro se é para o repórter ter o que divulgar ou outra ideia. Para ele, "não dar informações erradas é suficiente para garantir a liberdade" e isso mostra de maneira clara o seu não entendimento sobre o tema.

No segundo parágrafo, a pontuação inadequada confunde o leitor no sentido de não se saber se é uma pergunta ou uma afirmação que faz. Além disso, o gênero em questão não permite que o autor relate ou mencione acontecimentos de sua vida pessoal. Ele nem sequer 
tem conhecimento sobre a estrutura dissertativo-argumentativa. Faz indagações e as responde a si mesmo: "deve ser".

O produtor não assume um ponto de vista e nem mesmo consegue desenvolver um texto minimamente compreensível. Verificamos, no texto referido, infrações a todas as metarregras de Charolles.

\section{6-9}

\section{Como garantir a liberdade de informação e evitar abusos nos meios de comunicação?}

Atualmente o mundo está sofrendo várias transformações por meio da globalização, que por sua vez, trouxe várias consequências como o desemprego estrutural. As informações nas últimas décadas cresceram em um ritmo muito acelerado e a tendência é crescer cada vez mais.

Podemos nos comunicar com o mundo sem sair de casa - através da internet. Ela nos traz muitos benefícios. Mas há os malefícios que nem sempre podemos evitar, e também por outros meios de comunicação. Um exemplo são as empresas de telemarketing que oferece seus produtos sem saber das necessidades ou dificuldades de quem está no outro lado da linha.

Não podemos conter o avanço das informações mas garantiremos a liberdade de informação a partir do momento que estaremos aptos à dignidade de nossos direitos, contribuindo com nossa parte, para construção de uma sociedade mais justa.

Evitaremos os abusos negativos dos meios de comunicação a partir do momento de nos mobilizar-mos a conte-los. Desse modo, estaremos transformando a história de nosso país e a nossa própria história.

\section{ANÁLISE}

Apesar do uso adequado do recurso da substituição (internet/meios de comunicação), houve muita informação entre os correspondentes. Desta forma, o interlocutor deve estar bastante atento para perceber o que foi dito. 
Macroestruturalmente, podemos dizer que o texto apresenta coerência, mas se formos pensar na sequência temática, percebemos que se fala bastante do avanço e da globalização e muito pouco sobre o abuso dos meios de comunicação e a garantia da liberdade.

Há uma boa articulação entre as ideias e partes do texto (MR4). No segundo parágrafo, o autor tenta colocar, mesmo que insatisfatoriamente, os benefícios e malefícios da internet, mostrando ter um conhecimento mínimo da estrutura do gênero.

A progressão, também a partir do segundo parágrafo, encontra-se bem trabalhada, já que retoma adequadamente o que foi mencionado no primeiro, através, por exemplo, da pronominalização (internet - ela). Além disso, apresenta exemplo, o que demonstra uma sequenciação do pensamento.

No terceiro e quarto parágrafos, notamos uma tentativa de solução para o problema abordado. No entanto, esta não fica muito clara para o leitor quando menciona: "mas garantiremos a liberdade de informação a partir do momento que estaremos aptos à dignidade de nossos direitos".

Assim sendo, verificamos que o texto tem um padrão de coerência razoável, mas peca ao abordar o tema de maneira superficial e também pelos desvios apresentados.

\section{7-4}

Muitas pessoas gostam de assistir, lê, vê qualquer coisa, por que não sabem qual a imformação necessária que está sendo discutida no mundo.

Se todos conhecerem os seus direitos, ninguém falaria da privacidade das pessoas, eles iriam se defender.

Ter um programa de TV que falasse sobre os princípais direitos das pessoas hulmides, com certeza nós teríamos imformações boas, necessárias e com mais liberdade a ser discutida.

Quando você recebe ou dar uma informação que é verdadeira, você irá ver que os abusos de comunicação irão diminuir, além disso não devemos dar ouvidos à qualquer coisa que falam por ai.

Sabe o que fazer para as pessoas não falarem qualquer coisa que só vai servir para elas?

- Dá audiência a um programa de TV que só mostra besteira (coisas que não irão servir no nosso futuro).

- Comprar livros que contam uma história de romance ou fictícia. 
- Comprar revista que falam sobre a vida de famosos, das pessoas que morreram, quem está com quem, etc...

Sem tudo isso teremos informações necessárias e liberdade de expressar nossas idéias.

\begin{abstract}
ANÁLISE
De maneira global, podemos dizer que nem mesmo há, por parte do autor, o real entendimento da proposta/tema.

Logo no primeiro parágrafo, encontramos uma falha no que diz respeito à MR3. Quando inicia dizendo: "Muitas pessoas gostam de assistir, lê, vê qualquer coisa, por que não sabem qual a imformação necessária que está sendo discutida no mundo", o síndeto utilizado não estabelece relação com o que foi dito antes.

O uso de modos e tempos verbais distintos acaba por deixar o texto bastante confuso no terceiro parágrafo, tornando-o desarmônico, afastando cada vez mais o leitor do texto.

No quarto parágrafo, encontramos, também, muitas incoerências em relação aos tempos verbais. De início, pensa-se que o fato já acontece (“Quando você recebe ou dar uma informação que é verdadeira [...]”), mas, posteriormente, notamos que se trata de uma "sugestão futura" para a resolução do problema ("você irá ver que os abusos de comunicação irão diminuir $[\ldots] ")$.

Em seguida, encontramos a falha mais grave do texto (MR3). O autor insere uma pergunta para o leitor, mas responde de maneira contraditória ao que deveria ter respondido. Há uma desarticulação total de seu pensamento: "Sabe o que fazer para as pessoas não falarem qualquer coisa que só vai servir para elas?" "Dá audiência a um programa de TV que só mostra besteira (coisas que não irão servir no nosso futuro)".

No entanto, no final, o autor deixa claro que aqueles tópicos (suas respostas às perguntas) são maléficos no seu ponto de vista, sendo contraditório mais uma vez. Esse é um tipo de texto que não convence, já que não consegue convencer nem o próprio autor sobre o assunto que aborda.
\end{abstract}

\title{
0126082-0
}

Hoje em dia existe muitos programas sençacionalistas que prejudicam a imagem das pessoas, porque muitas vezes, não sabem ao certo o que de fato ocorre. Chegam invadindo 
casa, indagando, questionando e até mesmo causando. Isso ocorre muitas vezes pela falta de respeito entre a sociedade, pois muitos não aceitam que esses repoteres publiquem algo sobre as suas vidas, mas a sociedade exigi isso, querem saber o que ocorre no mundo para tomarem cuidado com tais situações.

A midia, muitas vezes, não se importam com que os outros pensam, eles simplesmente querem fazer o seu trabalho, e com isso acabam gerando conflito na sociedade. A sociedade em si, acaba gerando também muita polemica pela falta de argumentos ou até mesmo pelo preconceito para com o trabalho, pois muitas vezes é preciso ser chato para se poder conseguir tal reportagem, e é ai que eles acabam pecando.

Para que de fato não ocorra tantas confusões, era necessário criar leis para a midia ter "livre árbitrio" para fazer suas entrevistas, pesquisas, sendo elas de uma forma culta, formal. A midia teria que marcar dia, hora, local para fazer o seu trabalho, sem ter que sair invadindo casas cortiços ou coisas do gênero, deixando assim o respeito fluir mas e melhor entre as pessoas.

A sociedade em si, exige respeito, mas também exigi informação, por isso é que existe uma grande rivalidade entre ambas, o que falta é o diálogo, o respeito, pois só assim é garantido a informação para a sociedad, mas sem desrespeito também.

\section{ANÁLISE}

São nítidos no texto acima os graves desvios à norma.

No primeiro parágrafo, encontramos um problema relacionado à coerência do texto. Apesar do uso satisfatório do paralelismo com vias à ênfase nos pontos negativos sobre o tema, o autor não o conclui, isentando o verbo de seu devido complemento: "Chegam invadindo casa, indagando, questionando e até mesmo causando"; o que acaba por prejudicar o entendimento do texto. Além disso, o excesso de pronominalização dificultou o estabelecimento de coerência no parágrafo.

Quando o autor insere o pronome "esses" para se referir a "repórteres", logo o leitor procura onde poderia ter sido citado anteriormente, mas o substantivo ainda não havia sido mencionado.

Logo em seguida, o pronome possessivo "sua" confunde-nos, pois sem uma leitura atenta, pode-se atribuir o termo tanto aos repórteres quanto à sociedade. 
Apesar de encontrarmos um bom exemplo do uso da MR1 no momento em que substitui "sociedade" pelo pronome indefinido "muitos", o produtor peca ao fazer mau uso dos pronomes subsequentes.

No primeiro parágrafo, basicamente, o produtor diz faltar respeito da sociedade. No segundo, ele já menciona que a culpa dos conflitos é da mídia e a sociedade é a geradora de polêmica. No terceiro parágrafo, conclui dizendo que a solução seria "a mídia fazer suas entrevistas de maneira mais formal". Desta forma, percebemos que não há conexão alguma no eixo temático.

O último parágrafo, apesar de ser iniciado de maneira satisfatória, também peca pela falta de coerência interna e demasiada repetição de ideias. Quando o produtor menciona "rivalidade entre ambas" não temos o outro referente no parágrafo. Além disso, os vocábulos "respeito/desrespeito" foram bastante utilizados, mas sem fundamentação.

\section{3-9}

\section{Como garantir a liberdade de informação e evitar abusos nos meios de comunicação?}

Sendo a maioria das impresas de jornalismo de setores privados, cuja qualquer decisão é desígnios de seu donos e idealizadores, torna-se difícil respeitar e privar a imagem das pessoas.

Nas quais muitas vezes são submetidos a constrangimento, vergonha e desmoralização perante a sociedade, que são telespectadores de programas sensacionalistas que usam a mídia como forma de adquirir informações e muitas vezes invadir casas ou barracos de populações carentes sem ter respeito pelos que ali habitam.

Tendo os programas de televisão o dever de emitir informações e fazer alertas a sociedade com um todo, os jornalistas chegam filmando, a fim de conseguirem uma boa matéria, que traga audiência aos seus programas e jornais que idependem de censura.

Estes programas são serviços públicos, amparados pela Constituição Federal com específicos privilégios. Mas que tidos como abuso, seus idealizadore podem sofrer uma idenização por violarem a moral e por danos morais.

\section{ANÁLISE}


Percebemos nesta produção que apesar dos desvios, ela inicia-se de maneira satisfatória e com progressividade. No entanto, temos a impressão de que o autor não se posiciona e não argumenta a respeito do tema. Temos uma "conclusão" que não finaliza e muito menos mostra um ponto de vista. É como se fosse um texto informativo e não argumentativo.

Fazendo a análise por parágrafos, notamos que logo no início do segundo, há uma infração à MR1 e MR2, pois não é sabido o referente, afinal, quem são submetidos?: "Nas quais muitas vezes são submetidos a constrangimento, vergonha e desmoralização perante a sociedade [...]". Obviamente, percebemos (se olharmos de maneira mais atenta) que se trata do substantivo "pessoas" do parágrafo anterior, mas a confusão é causada devido ao mau uso de conectivos entre os parágrafos (o que nos leva à infração da MR4), bem como à flexão de gênero inadequada da palavra "submetidos", a qual deveria ser "submetidas".

Mais uma vez, no segundo parágrafo, a falta de coerência ocorre pela ausência de organização das ideias do produtor: "Nas quais muitas vezes são submetidos a constrangimento, vergonha e desmoralização perante a sociedade, que são telespectadores de programas sensacionalistas que usam a mídia como forma de adquirir informações [...]”

O terceiro parágrafo é bem estruturado com conjunções adequadas. No entanto, no último, encontramos uma grave infração à MR3. No primeiro parágrafo, o autor menciona que a maioria das empresas de jornalismo são privadas; e no último, que são serviços públicos. Assim, este contradiz totalmente aquele.

Em suma, o autor não insere o real objetivo do texto, que é dizer como garantir a liberdade de informação e evitar abusos nos meios de comunicação e, além disso, infringe todas as metarregras.

\section{0-2}

Acredito que a imprensa deva ser regulada, ou melhor, fiscalizada por uma instituição a ser criada dentro das determinações e anseios populares, estando acima de expeculações empresariais e políticas.

Sendo assim proponho, não a censura, mas o respeito dos órgãos de informação de massa aos direitos instituídos.

E visto que os meios de comunicação possuem longo alcance em todo o território brasileiro a conjuntura política facultativa deverá de imediato ortogar a independência. 


\begin{abstract}
ANÁLISE
Logo de início, percebemos o caráter não impessoal da redação, o que não é aceito por essa modalidade escrita dissertativo-argumentativa.

O produtor inicia seu texto mencionando o que deveria ser mudado, não colocando o que de fato ocorre, os pontos negativos ou positivos. Vemos, nesse momento, uma infração à MR4 com relação ao eixo temático.

Apesar de o texto ser compreensível e, de certo modo, apresentar coesão, notamos falta de coerência macroestrutural. Não há progressão e nem mesmo estruturação de ideias adequadas ao real objetivo do texto.

Faltam pontos de vista mais elaborados e aprofundamento do tema.
\end{abstract}

\title{
0126120-7
}

\section{O Povo consiente}

O Brasil esta em ano de política, por isso o leitor tem que analizar bem o candidato que vai votar, o passado político deles é exencial para o cidadão pesquir. Principalmente aqueles deputados que so fazem promesas, e não comprem.

Sempre nessas épocas recebemos vizitas de candidatos pedindo votos, geralmente eles fazem promesas: dizem que vão asfaltar as ruas, saneamento basico. Tudo isso é para eles terem o poder nas mãos.

Mas o eleitor acredita naquele candidato naquele candidato que tem ideias de melhorar a sua cidade ou o seu bairro pelomenos, vota nele e nem sabe a vida política. O que o cidadão deve fazer é testar em quem ele pretende votar, guando o candidato ganhar e fazer tudo aquilo que promete o eleitor quem que votar nele de novo ou caso contrario não ganha mas o seu credito.

Por tanto devemos analizar bem em quem vai ser os nossos representantes.

\section{ANÁLISE}


O primeiro aspecto que deve ser mencionado sobre a redação é que há uma total desarticulação entre o tema proposto e o texto, configurando uma fuga total ao mote da proposta.

Os desvios em nível formal, especialmente no tocante à ortografia, à acentuação gráfica e à pontuação são graves. Percebemos que a falta de uma revisão mais criteriosa também contribuiu para a incoerência do texto, tendo em vista que o autor inicia algumas palavras e não as termina.

Em se tratando das metarregras (embora a temática desenvolvida seja outra), devemos dizer, primeiramente, que a repetição de palavras e termos configura infrações à MR1, haja vista que não são utilizadas com o propósito de manter uma sequência lógica do tema; são reiterações realizadas por descuido e falta de atenção: "Mas o eleitor acredita naquele candidato naquele candidato".

Infrações à MR4 também podem ser encontradas, pois faltam, em todo o texto, conectores entre as palavras, orações, períodos e ideias.

Não há progressão, principalmente, entre o primeiro e o segundo parágrafo, pois este é apenas uma repetição daquele.

Temos, pois, bons exemplos de reiteração, embora tenham sido utilizados de maneira inconsciente. No segundo parágrafo, o autor substitui gramaticalmente o termo "candidatos" pelo pronome "eles" e, também, fazendo a retomada por elipse no verbo "dizem": "Sempre nessas épocas recebemos vizitas de candidatos pedindo votos, geralmente eles fazem promesas: dizem que vão asfaltar as ruas, saneamento basico." Depois, conclui: "Tudo isso é para eles terem o poder nas mãos.", proporcionando uma certa progressão ao texto, já que retoma e acrescenta novos pensamentos.

No entanto, o contrário também ocorre, pois o emissor utiliza o mesmo recurso de maneira indevida. No trecho: "O Brasil esta em ano de política, por isso o leitor tem que analizar bem o candidato que vai votar, o passado político deles é exencial para o cidadão pesquir. Principalmente aqueles deputados que so fazem promesas, e não comprem.", o autor reitera o vocábulo "candidato" através dos demonstrativos "deles" e "aqueles". Se os pronomes não estivessem no plural, não haveria problema.

Em suma, o autor repete ideias, tem dificuldade em expô-las e argumenta de maneira ineficaz, corroborando a falta de coesão e coerência do texto. 


\section{3-9}

\section{Como garantir a liberdade de informação e evitar abusos nos meios de comunicação?}

Não samos mais o mesmo, desde que surgiu os meios de comunicação, pois estamos vivendo num mundo globalizado, dispeitados por aqueles que querem algo maior na vida. Em nossas casas vivemos colados com a informação, será que da mos ajuda para expressar nossas ideias.

Os meios de comunicação entram em nossas vidas sem pedir licença para entrar, os programas sencionalistas do rádio e os programas de televisão mostram o que querem, a qualquer horário do dia, não pensando na família, na sociedade em que se encontra, nossos irmãos em vez de assistirem jornais, esportes no horário da tarde e da noite estão assistindo guerras brigas de vizinhos, mortes, pois é essa a nossa realidade. Para que possamos ter um país digno devemos acabar com isso.

Não sabemos quando isso irá acabar, sabemos que existe uma esperança em nós brasileiros para que torne-se realidade. Temos que acabar com o abuso das informações que eles colocam no ar aquilo que não é a realidade.

\section{ANÁLISE}

De maneira global, podemos dizer que o texto apresenta várias incoerências microestruturais.

No primeiro parágrafo, o autor menciona que a partir da globalização, as pessoas não são mais as mesmas por cada um querer algo "maior" na vida. Temos aí uma infração à MR2, já que não há um prosseguimento do que foi dito, ficando obscuro para o leitor o que seria esse "algo maior".

A falta de reflexão sobre o uso do vocábulo adequado ocorre em seguida, quando o autor menciona que "Em nossas casas vivemos colados com a informação" e finalizando de maneira pouco clara: "será que da mos ajuda para expressar nossas idéias".

Também encontramos um problema com relação à aceitabilidade do texto pelo leitor no momento em que menciona que "os meios e comunicação entram em nossas vidas sem pedir licença". Como seria isso possível?

No final do segundo parágrafo, é dito que para termos um país mais digno, deveríamos acabar "com isso". O uso do pronome demonstrativo "isso", embora, provavelmente, não 
tenha sido esse o propósito, retoma "a nossa realidade". Desta forma, acabaríamos com a nossa realidade? Mesmo se o produtor tivesse dito "acabar com os programas, jornais, etc", poderíamos, no momento atual, fazer aceitação de tal proposta?, ou seja, não mostrar mais a realidade através dos meios de comunicação, inventando um novo mundo, fantasioso?

O problema mais grave se encontra no último parágrafo, em que visualizamos nitidamente a infração à MR3. O autor contradiz totalmente o parágrafo anterior ("pois é essa a nossa realidade"), já que neste menciona "que eles colocam no ar aquilo que não é a realidade".

\section{0-1}

\section{A Liberdade de se expressa}

A liberdade é uma coisa, que nós temos que ter, porque sem a liberdade e mesmo que nós estarmos preso a nós mesmo.

Sem a liberdade nós não podemos ser livre. E principalmente quando falamos da liberdade de ser informação, se nós não ficamos sabendo de tudo que está acontecendo, nós perdemos a noção do que está acontecendo, o que está passando, sem a liberdade de informação nos não sabemos absolutamente nada.

Já os abusos nós meios de comunicação hoje em dia é constante, principalmente quando falamos sobre o meio de rádio, televisão, telefones e outros.

Através da televisão muitas vezes virmos coisas absurdas, muitas mostram coisas que aumenta o número de violência, podendo mostrar coisas que trazem benefícios as pessoas não, só mostram para piorar.

No rádio ouvimos coisas mais absurdas do que a outra, é pessoas se discriminando as outras, ao invés de colocarem programas que falam de coisas boas, de uma educação melhor, não só se xingam um aos outros.

E ai que veremos os meios de comunicação são abusos, não so esses, muitos outros.

\section{ANÁLISE}

Esse texto apresenta problemas, primeiramente, em relação ao uso desequilibrado dos requisitos de repetição (MR1) e progressão (MR2). A repetição, utilizada por demonstrar a 
retomada e a manutenção da mesma sequência temática, fica empobrecida pelo uso automático das mesmas palavras, que, por sua vez, foram retiradas do tema.

Em apenas uma linha (a primeira), temos duas ocorrências da palavra "liberdade", sendo que esta poderia ter sido usada através de um dos mecanismos da textualidade. No parágrafo seguinte, ocorre a repetição do mesmo vocábulo.

No início do segundo parágrafo é gritante a expressão: "Sem a liberdade nós não podemos ser livre".

Percebemos que para o autor, o conceito de "liberdade de informação" se iguala ao ato de "informação" puro e simples. Não há uma distinção entre as duas expressões, o que acaba por evidenciar a falta de conhecimento de mundo do produtor.

Mais uma vez, no quarto parágrafo, a ausência de argumentação faz com que aconteça a repetição da palavra "coisa", que por sua vez, tem o significado bastante vago.

Em síntese, o texto apresenta demasiada repetição (MR1), não há progressão (MR2) e, com relação à MR4, parece-nos que o texto está dividido em duas partes (liberdade de expressão e abuso nos meios de comunicação). Não há conexão do eixo temático.

\section{1-4}

\section{Objetivo sério de informação}

A liberdade de expressão própria vem causando problemas e adequando casos, como expansão de notícias de conhecimento não tão bem favoráveis, produzindo assim argumentos de temas variados.

Ao objetivo de fatores ocorridos decorrentemente, identifica aos receptores o processo que envolve existência sobre o que acontece no país.

Trata-se de comunicação exercida por anunciantes ou fatos verídicos relacionando a vida de pessoas, adquirindo informações objetivas destes acontecimentos surge então informações desenvolvidas incondicionais sem responsabilidade.

Portanto, com essas informações a comunicação exerce a representação de programas, buscando de forma, responsável um trabalho sério, obtendo informações construtiva, havendo assim intelectualidade sobre o que informar. 
Globalmente, aparenta-nos que o produtor tentou utilizar uma linguagem formal, sem conhecê-la, ou seja, muitas vezes, ele não tinha consciência do valor semântico das palavras, causando uma enorme confusão em seu texto.

Primeiramente, não se sabe o que ele quis dizer com a expressão "liberdade de expressão própria" (talvez propriamente). Logo em seguida, ele menciona que essa "liberdade vem adequando casos", o que torna o texto ainda mais obscuro, já que o leitor não faz uma explicação a respeito. Ainda nesse mesmo parágrafo, fala "expansão de notícias [...]", mas favoráveis a que/quem? Em suma, não há uma compreensão efetiva de todo o primeiro parágrafo.

A mesma falta de clareza ocorre no segundo parágrafo.

No terceiro parágrafo, apesar de surpreendentemente ser compreensível, não faz relação com os parágrafos anteriores (MR4).

Encontramos no último parágrafo uma infração à MR3. Do pouco que se pôde entender do texto, verificamos uma contradição em relação ao parágrafo anterior, pois, primeiramente, o autor menciona que surgem informações. Depois pronuncia que "[...] com essas informações a comunicação exerce a representação de programas, buscando de forma, responsável um trabalho sério, obtendo informações construtiva, havendo assim intelectualidade sobre o que informar.".

Em suma, o texto apresenta infrações a todas as metarregras.

\section{0-0}

\section{Tema: Como garantir a liberdade de informação e evitar abusos nos meios de comunicação?}

Hoje são abusivas e perseptivas vermos quaisquer tipo de "abuso" em televisão aberta, a que leva principalmente a jovens praticarem hatos indeligüentes, ou as chantagens de melhor oferta persentual de mercado, levando o telespectador a epnase [impasse?], e que pode mos perceber que o povo não tem voz e as vezes não é passada a ele as imformações necessarias a ele para se alto informar através desses meios oferecidos mais subordinados pelos supremos (governantes), que não nas informação direta os assuntos que o povo tem direito como educação, infra-estrutura etc, já que representantes que o povo escolheu não fazem nada contra isso, alguém capaz de articular se fosse possível. Da uma cutucada para 
que ao mesmo se espertem e criem leis que deiam liberdade de seu povo informar e formar proposta assim determinada.

\begin{abstract}
ANÁLISE
Nota-se, de imediato, que o texto é bastante confuso. Essa confusão se torna ainda mais aparente ao percebermos que o produtor nem mesmo faz o uso da paragrafação. Além disso, outro aspecto que se destaca é o fato de o aluno usar apenas um ponto dentro de um parágrafo tão extenso (próximo do final). Por não explorar esse mecanismo de coesão, a redação assemelha-se ao conhecido recurso literário chamado "fluxo de consciência", mas a distinção é que, na redação, pouco se consegue entender.

No início, já nos deparamos com uma frase sem objetivo específico, tendo em vista que não fica claro para o leitor o que o produtor pretendeu dizer: "Hoje são abusivas e perseptivas vermos quaisquer tipo de "abuso" em televisão aberta [...]".

Em seguida, há uma sucessão de ideias não muito claras que não têm articulação alguma. Encontramos nesse texto todas as infrações às metarregras.

Não há, por parte do aluno, o conhecimento mínimo sobre a elaboração desse gênero, muito menos conhecimento de mundo suficiente para a produção do texto.
\end{abstract}

\title{
0126188-6
}

O abuso de poder e descumprimento das regras, vem ocasionando discursões e criações de leis que proíbam a invasão na vida das pessoas, fazendo com que se retirem o poder de autoridades das imprensas de jornalismo e comunicação.

A imprensa hoje em dia está violando regras que impôem sobre a sociedade, quebrando sigilos da vida pessoal da população, tudo para possuir maior credibilidade no ramo de comunicação. Mas nem sempre as pessoas concordam com esse abuso de poder, pois revelam o que se passa constantemente em sua vida e, se torna constrangedor vendo sua vida repassada a outros, más em forma de crítica sobre o que se passa em seu meio social.

Com isso a imprensa se propõem a debater os meios em que se pode atuar, mas com rígida investigação sobre o abuso de autoridade. A vida de cada pessoa depende de eu sigilo e de não contradições como a imprensa faz, por isso o seu meio de informação deveria englobar 
as situações em que reaumente há crítica sobre políticas, sobre as crises ambientais e culturais.

Más no entanto sabemos que a imprensa não deixaria de favorecer a dose que realmente interesse a si próprio, ficará sempre quebrando e fugindo de sua real profissão e incomodando a vida de pessoas que nada tem a ver com sua função.

\begin{abstract}
ANÁLISE
Através do primeiro parágrafo, podemos perceber, de imediato, a falta de conhecimento do produtor sobre o assunto. Há certa confusão perceptiva de conceitos, tais como: abuso de poder/abusos nos meios de comunicação. Além disso, não são esclarecidas para o leitor quais regras vêm sendo descumpridas.

Verificamos também a falta de reflexão do produtor, tendo em vista os textos da proposta de redação do ENEM, já que este "defende" exatamente o oposto do que nos é mostrado.

Notamos, no segundo parágrafo, uma reiteração em relação às regras mencionadas no parágrafo anterior, mas, mais uma vez, o autor não esclarece que regras são essas.

O primeiro período do terceiro parágrafo é bastante confuso e não fica claro ao leitor a intencionalidade do produtor.

Em conclusão, é um texto que apresenta diversas falhas no que se refere ao campo semântico, lexical e sintático. As incoerências internas prejudicam demasiadamente o texto.
\end{abstract}

\title{
0130000-8
}

\section{A imprensa fiscalizada}

Um canal mostra um assalto, o outro mostra um assassinato, enquanto um último faz uma visita para um presídio de segurança máxima para entrevistar um traficante. É isto que se vê na televisão brasileira, com o intuito de mostrar e não informar, vender e não educar. Mas como associar liberdade de expressão com direitos humanos?

A lei de liberdade de expressão foi um direito conquistado depois de muita luta contra a censura que retirava a voz da imprensa, deixando-a calada diante de grandes problemas sociais, além de fazer dela apenas uma propagandista do governo ditatorial. 
Mas com a conquista desse direito a imprensa começou a manipular a população com seus noticiários e programas e a abusar do seu poder, passando por cima de artigos da constituição federal brasileira que asseguram que a privacidade é inviolável, invadindo lares e vidas que anseiam por serem deixados em paz.

Além disso a televisão brasileira está deixando de fazer seu principal papel, que é educar e informar, para se tornar apenas uma forma de se ganhar dinheiro, mostrando programas absurdamente imorais e sem conteúdo intelectual e informativo.

Por isso a imprensa em geral deve ser duramente fiscalizada não pelo governo mas pela sociedade que tem o direito e o dever de criticá-la e puni-la não lhe dando a sua audiência para programações que achar moral e eticamente errados.

\section{ANÁLISE}

O texto acima é um exemplo do uso correto, na maior parte do tempo, dos requisitos de coerência. Facilmente sabemos o que o autor quer dizer, isto é, não há problemas com relação à decodificação textual.

A boa estruturação é resultado da articulação das ideias e partes do texto (MR4). Na introdução, verificamos que há um objetivo determinado pelo aluno: falar sobre a liberdade de expressão e os direitos humanos. O restante do texto, de maneira coerente, mantém-se metódico em relação ao plano estabelecido: o segundo parágrafo fala sobre a liberdade de expressão; o terceiro sobre a manipulação da imprensa; no quarto o produtor expõe sua opinião sobre a televisão atual; e no último dedica-se à conclusão.

A progressão (MR2) encontra-se bem trabalhada no segundo parágrafo, quando inicia informando que "A lei de liberdade de expressão foi um direito conquistado depois de muita luta [...]", retomando, adequadamente, a pergunta deixada ao leitor no primeiro parágrafo: "Mas como associar liberdade de expressão com direitos humanos?".

No quarto parágrafo, encontramos um bom exemplo da MR1, em que a palavra "imprensa" é substituída lexicalmente pelo hipônimo "televisão". Verificamos que essa metarregra é usada sem exagero, caracterizando a manutenção temática.

Temos, portanto, no que diz respeito à coerência, um texto quase incontestável, não fossem algumas falhas estruturais e a conclusão, a qual poderia ter tido mais conturbação. 


\section{5-6}

Nos dias atuais, a imprensa tem a liberdade de mostrar o que quer para o mundo, porém foi depois de muitas lutas que ela conseguiu ser "livre".

Existe uma diferença da imprensa de 1968, quando Vargas proibia a mídia de falar a verdade sobre política e da imprensa hoje onde se pode falar a verdade, mas é mais conveniente falar o que querem. Hoje as pessoas preferem assistir um programa onde um agride o outro ao invés de ver ou ouvir um bom jornal.

Muitas notícias que são um escândalo são várias vezes abafadas pela mídia as vezes por beneficio próprios e outras vezes porque há alguma vantagem com isso. Por isso algumas pessoas preferem assistir um programa onde fale da vida dos artistas ou que fale sobre algum problema que está acontecendo com uma família mais humilde.

É preciso mostrar a verdade para as pessoas e não só o que é conveniente para a mídia, pois assim as pessoas podem parar de assistir programas onde se fala da vida alheia.

\section{ANÁLISE}

Esse texto também não oferece dificuldades de decodificação, embora seja fraco com relação à argumentação.

No parágrafo introdutório, nos é apresentado apenas o tema sobre a liberdade de imprensa, não englobando os abusos dos meios de comunicação.

No segundo parágrafo, temos um bom exemplo da MR2, pois o autor retoma e insere novas informações sobre a imprensa.

Com relação à MR3, encontramos uma falha grave no terceiro parágrafo, já que este contradiz o segundo. Primeiramente, o autor menciona que "a imprensa hoje fala a verdade" e, posteriormente, ele diz "Muitas notícias que são um escândalo são várias vezes abafadas". Ainda nesse parágrafo, notamos que a falta de atenção ocasiona uma redundância no texto: “as vezes por beneficio próprios e outras vezes porque há alguma vantagem com isso.”. Não seria o mesmo?

Vemos que o produtor discursa sobre os programas exibidos na televisão e nada menciona sobre os abusos e a liberdade de informação. Não há uma conexão do último parágrafo aos anteriores. A falta de conhecimento de mundo do aluno ficou bastante evidente na redação. 


\section{6-1}

\section{Imprensa X privacidade}

A imprensa tem por objetivo levar informações a população sobre o que acontece e no cenário público, econômico, cultural e social, porém ela vêm há algum tempo se ultilizando do sensacionalismo para a obtenção de uma expressiva audiência, o que é incorreto.

O que ocorre são abusos por parte dos veículos de comunicação, como exposição de dramas vividos por famílias humildes, escandalos envolvendo celebridades ou políticos, violando as veses a intimidade dessas pessoas.

O que devemos fazer é lutarmos para garantir o direito de sabermos o que ocorre em nosso redor, mas que seja mostrado de forma séria, pois o produto jornalístico se trata de um serviço público. Deveria haver um maior icentivo a auto-regulação para as empresas de comunicação, pois depende deles o início da mudança, para a volta de valores como o respeito ao próximo.

\section{ANÁLISE}

O texto analisado é de fácil compreensão, apesar de apresentar várias falhas. Logo no início, o uso indevido do síndeto "e" ocasiona problemas com relação à interpretação textual, já que o período “[...] levar informações a população sobre o que acontece no cenário publico [...]" não tem sentido. Desta forma, o mais correto seria retirar a conjunção.

No mesmo parágrafo, verificamos um bom exemplo da MR1, em que percebemos a substituição gramatical do substantivo "imprensa" pelo pronome "ela". Outras reiterações por pronomes relativos também devem ser lembradas nesse texto, pois a este dão continuidade.

A seguir, no segundo parágrafo, encontramos uma progressão adequada quando nos são apresentados exemplos de abusos dos meios de comunicação.

O parágrafo também está bem articulado no que se refere às ideias inseridas no texto. O problema está na falta de seguimento adequado da proposta, pois pouco se fala sobre a garantia da liberdade de informação.

Além disso, apesar de o autor tentar propor uma solução para o problema, não nos mostra de que maneira poderíamos "lutar" para garantir o direito requerido. 


\section{2-0}

\section{Nova qualidade}

A liberdade de expressão e informação garantida na Constituição brasileira de 1988 só será possível quando os abusos dos meios de comunicação forem evitados, e um novo conceito de qualidade chegar ao conhecimento da imprensa.

Não faz muito tempo que a imprensa foi manipulada e censurada pelo governo da ditadura militar. Desde então, mesmo com o fim daquele governo, a mesma continua sendo moldada, desta vez para mostrar imagens sem fins informativos, com a finalidade de transmitir notícias que não possuem um resquício sequer de utilidade. Além disso, ainda mostra imagens de pessoas sofrendo, pessoas pobres, inaugurando o sensacionalismo nos meios de comunicação, o que praticamente aniquilou com o pouco de qualidade que existia na imprensa.

Para consertar toda esta confusão, a imprensa deveria deixar de ser uma massa de modelar para se tornar algo sólido, forte e concreto que transmita credibilidade. Para tanto, deve começar a fazer a qualidade de reaparecer, fazendo com que informações úteis sejam veiculadas.

Enfim, para que tenham um canal de informação com credibilidade para repassar qualidade, é necessário primeiro acabar com o sensacionalismo, para que passemos a ter programas de cunho informativo e produtivo.

\section{ANÁLISE}

Com relação aos termos de estruturação do texto dissertativo, o esquema textual de introdução, desenvolvimento e conclusão pode ser considerado adequado, embora apresente algumas falhas. Fica claro, na introdução, o assunto que será abordado. No entanto, o autor não deixa muito visível para o leitor a que qualidade se refere no fim do parágrafo.

No segundo parágrafo, o produtor consegue aquele equilíbrio desejado por Charolles entre MR1 e MR2. Temos a substituição lexical da palavra "imprensa" por "a mesma" e "meios de comunicação". Além disso, o aluno faz uma retomada por elipse, a fim de não causar uma repetição: “[...] ainda mostra imagens de pessoas sofrendo [...]”. A progressão é clara, embora a informatividade não seja tão elevada.

No terceiro parágrafo, o uso indevido de um conector causa incoerência à ideia exposta: “[...] fazer qualidade de reaparecer [...]". A preposição "de" não possibilita ao autor 
chegar ao seu real objetivo, que era dizer "[...] fazer a qualidade reaparecer, com informações úteis".

O último parágrafo se mostra conclusivo, embora não apresente concretividade. Falta ao texto um aprofundamento maior do tema.

\title{
0130053-9
}

\section{Informação e evolução}

Com o avanço tecnológico e científico as redes informacionais estão muito mais eficientes, fazendo com que diversos acontecimentos nacionais e mundiais cheguem ao domínio das pessoas com uma velocidade extraordinária, através da mídia, entretanto, acaba ocorrendo certos "abusos" por parte desta.

O foco principal da mídia é a informação rápida e coerente, com o objetivo de transmitir os fatos para o público alvo, às vezes, esta forte arma do século XXI ocasiona conseqüências não muito positivas, as quais acabam gerando diversos conflitos. Pode-se afirmar que a mídia é uma espécie de "máscara", ou seja, ela mostra a realidade porém de uma maneira diferenciada, um pouco mais dramática, abusando desta forma, de eu grande poder persuasivo.

Como não só a mídia, mas sim todos os meios de comunicação, possuem essa grande influencia no modo de vida das pessoas, estas deveriam usar suas fontes sem esse grande "exagero" e assim sendo tornar as informações mais dinâmicas.

Enfim, chega-se a conclusão que os meios de comunicação estão abusando definitivamente de seu poder, mas se houver uma redução nesse setor as redes informacionais se tornarão o caráter diferencial do homem, ou seja, a evolução.

\begin{abstract}
ANÁLISE
Uma leitura global revela que o texto apresenta uma desarticulação em relação ao tema proposto pelo ENEM, já que é enfatizada a questão do avanço tecnológico. A falta de conhecimento vocabular também é evidente quando o autor "inventa" a palavra "informacionais", ao invés de "de informação"

No primeiro parágrafo, encontramos o uso correto da MR1 quando o autor substitui a palavra "mídia" pelo pronome contraído "desta".
\end{abstract}


Não há progressão no segundo parágrafo, pois o autor não retoma “abusos", mencionados anteriormente e nem mesmo exemplifica as consequências negativas de que fala neste momento.

A ideia de que "todos os meios de comunicação possuem influência na vida das

pessoas" é, de certa forma, generalizante, pois depende muito do público-alvo de cada veículo.

O marcador de sequenciação "enfim" deixa claro a conclusão do texto. No entanto, esta não é suficiente. $\mathrm{O}$ autor não esclarece que tipo de redução poderia ser feita.

Desta forma, percebemos que falta ao aluno conhecimento de mundo necessário para produção de um texto argumentativo de qualidade.

\section{0-9}

\section{Meio de comunicação abuso contra os cidadãos}

Os meios de comunicação sempre foi usado para transmitir, ajudar e informar as pessoas, nem sempre é isso o que acontece pois diversas vezes as netrias [matéria] que são publicadas acaba tirando a privacidade das pessoas e nem sempre o que se fala é verdade, e isso prejudica a integridade da pessoa que está sendo acusada.

Diversas netrias [matéria] que são publicadas sobre uma determinada pessoa pode acabar com sua vida em todos os sentidos, pois ela passará a ser vista pelas outras pessoas de outro medo como um acusado de um crime, estrupo e outros, por isso a midia tem que ter muito cuidado quando expor um problema para a população.

A maior parte das netrias [matéria] que são passadas para os telespectadores nem sempre é verdade, isso deixa a população confusa e pode acusar uma pessoa sem que ela seja realmente o autor do crime. Isso acontece constantemente com as pessoas de baixa renda onde está localizada o maior indice de criminalidade.

Quando uma netrias [matéria] é exposta ao telespectador no mesmo momento ele tem sua posição sobre esse assunto, mas quando a netrias [matéria] passada é mentira a pessoa ou o grupo no qual está sendo acusado passará por vários constrangimentos podendo ter sua vida arruinada, pois será quase impossível essa pessoa arrunar um emprego e tr sua vida normal como antes.

Os meios de comunicação devia se preucupar mais com a integridade da pessoa que está sendo acusada, respeitando seus direitos e jamais invadir a prioridade do acusado. A 
fiscalização devia ser mais rígida contro os meios de comunicação para tentar coibir as falsas netrias [matéria] e que fosse passado apenas a verdade para o telespectador.

\section{ANÁLISE}

Através da análise, foi possível verificar que o restrito conhecimento de mundo do autor interferiu de forma marcante na elaboração do texto. A dificuldade argumentativa associada à repetição de ideias tornaram o texto pobre.

No início do primeiro parágrafo, falta ao verbo "transmitir" o seu complemento, o que gera questionamento por parte do leitor ao indagar "transmitir" o quê?

Os desvios à norma são diversos, no entanto, não chegam a interferir no entendimento do texto.

Em toda a produção, verificamos uma falha no que diz respeito à MR1, pois o autor repete diversas vezes o vocábulo "netrias [matérias]", o que tornou o texto cansativo.

Além da repetição lexical, temos também a repetição das mesmas ideias, já que o segundo, terceiro e quarto parágrafos falam basicamente o mesmo.

Verifica-se, pois, grande repetição devido à pobreza vocabular e ao pouco conhecimento do tema abordado.

\section{5-7}

\section{Onde há direitos, há deveres}

Os meios de comunicação tem indiscutivelmente função pública e deveria atender às necessidades das grandes massas, de certa forma, através dos programas sensacionalistas, as mesmas são "atendidas", mas por trás disso são os acionistas e grandes empresários que lucram investindo em lixo "informativo" que explora as mazelas da sociedade, não com o intuito de denunciá-las aos governos, mas sim de banalizá-las.

A falta de interesse por conteúdo educativo se prova com a divulgação dos baixissimos índices de audiência na "TV cultura", por exemplo, que é uma emissora que transmite aos seus telespectadores (poucos diga-se de passagem) cultura e linguagem regional curiosidades, desenhos animados, questões políticas, música e dança de forma inteligente.

Por essas e outras razões, deve sim haver uma fiscalização para os conteúdos televisivos, e na mídia em geral, mas não vista como uma forma de repressão e censuras, e sim como uma reciclagem do que nada acrescenta intelectualmente. Tendo em vista que 
acarretará um progresso educativo da informação, já que a mídia tem forte influência na vida das pessoas, e por conseqüência, mesmo que lentamente, o desenvolvimento social.

Onde há direitos, já deveres, com isso a imprensa da mesma forma que tem direito de divulgação, tem o dever de responsabilidade social, e aqueles que se sentem ameaçados, alegando repressão ao conteúdo do que divulga, é porque pode não estar cumprindo com seus deveres.

\section{ANÁLISE}

Falta à introdução clareza sobre o tema que será abordado, pois muitas informações são mencionadas. O que ocasiona também esse problema é a pontuação inadequada e a falta de conectivos, recursos da coesão e coerência do texto. Vemos uma grande falha relacionada à MR4 logo no início do primeiro parágrafo, em que não há conexão entre as orações: " $e$ deveria atender às necessidades das grandes massas," e "de certa forma, através dos programas sensacionalistas, as mesmas são 'atendidas' [...]”.

A partir do segundo parágrafo, percebemos que há uma melhora na articulação das ideias, apesar de não haver progressão, tendo em vista que a informação colocada não tem ligação com o parágrafo anterior.

No terceiro parágrafo, o autor expõe sua opinião a respeito dos abusos e menciona que deve haver fiscalização. No entanto, em um determinado momento, o autor, de maneira generalizante, pode causar uma inaceitabilidade por parte do leitor ao dizer que "[...] nada acrescenta intelectualmente", pois o aprendizado é algo muito subjetivo. No parágrafo conclusivo, a falta de substituição pode provocar confusão no leitor. Apesar de haver retomada por elipse (“da mesma forma que tem direito de divulgação, tem o dever de responsabilidade social [...]"), o vocábulo deveria ser retomado pelo menos mais uma vez. Temos, nesse parágrafo, duas retomadas por elipse e uma substituição gramatical ("seus”), o que pode ocasionar dúvida no leitor, interferindo na coerência do texto.

\section{3-9}

Em minha Opinião, eu não acho que os Repórter, Radialista, Jornalistas, abusam de nossa liberdade de informação e nem os meios de comunicações, acho que este é o Serviço deles procurar sempre manter a população informada dos acontecimentos que ocorrem no mundo, no nosso dia-a-dia, com a nossa humanidade. 
Ninguém é entrevistado por intimidação, fala quem quer, dizer o que quer e o que pensa, não é obrigado, já passou a época em que um ser humano é obrigado a fazer o que não quer, você só será entrevistado se aceitar a falar o que pensa e o que quer, poriso não acho que devemos Garantir a liberdade de informação e nem evitar abuso nos meios de comunicações, acho que deveríamos nos preocupar com assuntos que tenha mais prioridades no momento como a fome, a falta de água no mundo, a Guerra e outros assuntos que preocupa a população, a violência que aumenta cada dia mais e mais. Sei que posso estar errada, não o melhor não acho errado, essa é a minha maneira de pensar, não acho que nós deveríamos nos preocupar em o abuso nos meios de comunicação não agora.

\section{ANÁLISE}

De imediato, podemos notar que o autor nem mesmo tem conhecimento sobre a estrutura do gênero. $O$ uso da primeira pessoa do singular deixa evidente a falha no aprendizado do aluno. A falta de conhecimento de mundo interferiu, demasiadamente, na elaboração textual, e a ausência de argumentação culminou no "achismo" superficial tão evidenciado atualmente pelos alunos.

Não há um parágrafo introdutório. O segundo parágrafo principia com uma generalização: "Ninguém é entrevistado por intimidação". A seguir, há uma sequência de opiniões sem fundamento, evidenciando ainda mais a falta de conhecimento de mundo do aluno.

Em síntese, todas as metarregras de Charolles aparecem infracionadas. O texto apresenta muitos problemas de coerência que repercutem na estruturação deficiente do conteúdo. O tema da proposta não é desenvolvido com discernimento.

\section{2-5}

\section{Livre arbítrio moderado}

O que Hitler e Getúlio Vargas têm em comum? Ambos criaram organismos de censura à imprensa no século passado. Getúlio burlou o artigo $5^{\circ}$ da constituição federal brasileira, reprimindo a liberdade de expressão criando o órgão governamental DIP, que censurava qualquer tipo de oposição ao seu mandato. Esta medida de Vargas foi insensata e nunca seria aceitaa nos dias atuais para controlar o abuso da imprensa. 
Nesse início do século XXI, os meios de comunicação perderam de vista seu principal objetivo: informar as pessoas. A imprensa está levando para as casas das pessoas, programas sensacionalistas e de cunho imoral, programas dos quais "Ratinho" e "Domingo Legal" são exemplos.

Para solucionar os excessos cometidos pela imprensa, deve ser aplicado um poder moderador sobre ela. Deve-se então, formar uma bancada de bons e respeitados jornalistas, para que eles próprios avaliem que tipo de informação deve ser passada aos cidadãos, nunca alterando ou manipulando os fatos para se favorecerem.

\section{ANÁLISE}

Iniciamos a leitura com um título contraditório: como pode haver livre arbítrio moderado?

O texto analisado não apresenta dificuldades para decodificação, no entanto, peca com relação à estrutura do gênero.

O primeiro parágrafo fala, basicamente, de censura e abuso da imprensa. Já no segundo, o autor menciona a falta de qualidade dos programas televisivos. No entanto, os abusos nos meio de comunicação não estão, necessariamente, relacionados à falta de qualidade dos programas, o que nos mostra a falta de progressão do texto (MR2) e articulação (MR4).

No terceiro parágrafo, o autor retoma o tema inserido no parágrafo introdutório (o abuso da imprensa), substituído pela expressão "excessos cometidos pela imprensa", na tentativa de propor uma solução. No entanto, seu objetivo não é alcançado, tendo em vista a falta de eficiência de sua proposta.

Enfim, apesar de colocar informações relevantes a respeito do tema, o autor peca com a falta de argumentação, apenas expondo fatos e não os contestando.

\section{0-7}

\section{Mídia à toda população}

A mídia é o meio de comunicação que permite a todos a possibilidade de obterem uma melhor informação e estarem atualizados com acontecimentos nacionais e mundiais. 
Não só com o jornalismo, mas também com outros programas, ela nos proporciona momentos de diversão e alegria. Algumas matérias, chegam a nos deixar assustados e até indignados, como ocorreu na grande cidade de São Paulo, onde moradores de ruas foram mortos. E outras que abusam daqueles mais desfavorecidos da sociedade, para fazê-los de "cobaia" para cubrir faltas em suas programações.

Podemos observar também, que em muitos casos a mídia invade a privacidade de muitos famosos e investigam suas vidas. São eles, os famosos paparazzos, que ganham a vida correndo atrás de notícias sobre o mundo dos famosos.

Contudo, a mídia precisa respeitar o direito de privacidade e dar a todos que a procura o mesmo direito, acesso e liberdade de expressão.

\section{ANÁLISE}

Com relação à estrutura dissertativa e argumentativa, podemos dizer que o autor não as domina. A introdução não traz o tema principal que deveria ser abordado, apenas faz uma tentativa de explicar o que é a mídia. Apesar disso, o segundo parágrafo retoma o primeiro e nele encontramos um exemplo do uso correto da MR1, quando o produtor faz a substituição gramatical do vocábulo "mídia" pelo pronome "ela".

Embora o grau de informatividade seja baixo, outros exemplos adequados da MR1 e MR2 são encontrados, como a substituição da expressão "algumas matérias" por "outras" e "daquelas mais desfavorecidos da sociedade" pelo pronome oblíquo "los".

O terceiro parágrafo também se constitui um exemplo do que o autor considera abusos. Na conclusão, espera-se um posicionamento a respeito do tema proposto, mas isso não acontece, já que o produtor deixa uma mesma incógnita a respeito do mote: de que maneira a mídia pode respeitar o direito de privacidade e ainda possuir liberdade de expressão?

\section{4-0}

\section{Como garantir a liberdade de informação e evitar abusos no meio de comunicação}

A informação sobre os fatos que acontecem, ou seja, nós obtemos todos os dias, sejam elas pelo anúncio no rádio, televisão, ou outros meios de comunicação é muito importante 
para nós, e também termos ciência no dia-dia sobre o que está acontecendo no mundo aí fora e nos prevenirmos dessas brutalidades que está só aumentando mais e mais.

No meio da comunicação está cada vez mais complicado de viver, tendo em vista a falta de expressão das demais pessoas com as outras, que só pensam em sí próprio que as vezes só precisa de um pouco de liberdade e um auxilio para conseguir se estabilizar na vida.

\section{ANÁLISE}

Falta à redação uma introdução clara ao tema. O conhecimento de mundo do autor é bastante restrito, o que dificulta o desenvolvimento do texto.

A produção é rica em problemas relacionados à MR4 e fatores pragmáticos relativos à informatividade. Todo o primeiro parágrafo pode ser questionado no que se refere à articulação lógica das ideias. Verifica-se pontuação inadequada, falta de conectivos, demonstrativo sem o referente, ou seja, falta de clareza total.

Podemos perceber uma intensa desarticulação das partes e ideias do texto, tanto local como globalmente falando.

Enfim, o texto analisado poderia ser considerado, com muita dificuldade, uma redação sobre violência e as relações interpessoais, mas nunca sobre como garantir a liberdade de informação e evitar abusos nos meios de comunicação.

\section{3-7}

\section{Como garantir a liberdade de informação e evitar abusos no meio de comunicação?}

É difícil resolver esse problema, que nos pertuba nos dias atuais. "Liberdade" é um expressão que não podemos ter no Brasil, pois, tudo é limitado, menos os abusos que são responsável por muitos conflitos nos dias atuais. Não há bem como "evitar" e garantir esses fatos. Ex: Quem faz os fatos se tornarem públicos é a mídia, que por sua vez castiga os pobres com sua invasão de privacidade que não tem argumentos para reivindicar seus direitos e dizer não.

Portanto quando veêm, sua vida está exposta em um programa de TV, sem muitas vezes terem a confirmação do seu crime, talvez sendo injustamente castigados.

Uma solução - multar, cada suas licenças obrigar a idenizar as vitimas, mostrar pras pessoas seu erro e corrigir, pois o verdadeiro culpado é aqueles que correm atrás de notícias e 
torna simples casos em grandes acontecimentos os jornalistas que por quererem noticiais interpretão simples casos em grandes crimes.

Para muciar esses fatos e preciso interpretar, corrigir e divulgar aquilo que é concreto e tenha objetividade em suas divulgações.

\begin{abstract}
ANÁLISE
Temos aqui um texto com diversas falhas relativas à coesão e coerência. Inicialmente, o autor não nos esclarece de que problema trata. Assim, essa lacuna deve ser preenchida pelo leitor que, por sua vez, dependendo do contexto, faz a leitura proposta e não consegue decifrar o que a expressão "esse problema" quis dizer.

Notamos certa dificuldade do autor em se expressar, como na passagem: "Liberdade é uma expressão que não podemos ter [...]”. Logo no primeiro parágrafo, encontramos uma infração à MR3 quando menciona que "[...] tudo é limitado [...]" e depois continua "[...] menos os abusos [...]". A repetição propriamente dita da expressão "nos dias atuais" também causa empobrecimento ao texto.

Outra falha grave é encontrada no terceiro parágrafo, no que diz respeito à contradição. Inicialmente, o produtor menciona não haver resolução para o problema; e, posteriormente, ele apresenta uma tentativa de solução, apesar de confusa e sem fundamento apropriado:

Uma solução - multar, cada suas licenças obrigar a idenizar as vitimas, mostrar pras pessoas seu erro e corrigir, pois o verdadeiro culpado é aqueles que correm atrás de notícias e torna simples casos em grandes acontecimentos os jornalistas que por quererem noticiais interpretão simples casos em grandes crimes.
\end{abstract}

Assim sendo, a falta de conhecimento de mundo associada à desorganização de ideias e dificuldades argumentativas culminou na construção de parágrafos desconexos que expõem pensamentos contraditórios, corroborando a falta de coesão e coerência do texto.

\title{
0254022-3
}

\section{Abusos em nossa sociedade}

Hoje em dia, muitas pessoas sofrem abusos, sejam eles: moral, físico e até sexual. 
No mundo de hoje, está muito dificil controlar os abusos em nossa sociedade, por que nós temos muita desigualdade social, que é o principal fator daquelas pessoas que são menos favorecida em nossa sociedade.

Essas pessoas que tem algum poder, autoridade abusam da boa vontade de algumas pessoas, para passar por cima delas, é o caso de certos políticos que tentam comprar votos de pessoas pobres em troca de dinheiro.

Mas também tem aquelas pessoas fracas de espírito, fazendo com que elas sejam um tipo de boneco de fantoche.

Por isso que nós devemos acabar com esses tipos de abuso na sociedade, por que todos nós temos os mesmos direito diante da Lei, com isso só tem um jeito de acabar certos abusos e garantir a liberdade, é tratando de pessoas com respeito e humildade.

\section{ANÁLISE}

Logo de início, percebemos que o aluno não tem conhecimento sobre a proposta ou mesmo mistura conceitos e ideias, encaminhando sua produção para outra direção/tema.

Muitos tipos de abusos são citados, menos o requerido na proposta. Temos, pois, uma fuga parcial ao tema proposto. No entanto, levando em consideração a tentativa de escrita do aluno, podemos analisar alguns aspectos referentes à coesão e à coerência.

Primeiramente, devemos dizer que o emissor não explica de maneira satisfatória o termo "abusos", tão empregado em sua redação. A repetição automática do vocábulo "pessoas" acaba por empobrecer o texto, configurando uma infração à MR1, já que a reiteração acontece sete vezes durante o texto. Ainda com relação a essa metarregra, encontramos outros exemplos bons e ruins.

No primeiro parágrafo, o pronome relativo retoma o termo "desigualdade social": "por que nós temos muita desigualdade social, que é o principal fator". No entanto, ao mencionar que "é o principal fator daquelas pessoas que são menos favorecida em nossa sociedade.", não se sabe "fator de quê", pois o autor não menciona no texto.

No parágrafo introdutório, um exemplo positivo do requisito da MR1 é quando o emissor, através do pronome "eles", retoma o termo "abusos": "Hoje em dia, muitas pessoas sofrem abusos, sejam eles: moral, físico e até sexual.".

De modo geral, podemos afirmar que a produção não apresenta tantos problemas no que diz respeito à decodificação, mas faltam embasamento e conhecimento de mundo por parte do emissor para conseguir produzir um texto satisfatório. 


\section{5-8}

\section{Como garantir a liberdade de informação e evitar abusos no meio de comunicação}

Os meios de comunicação hoje é um produto de alienação de penssamentos.

Os programas policias não devem acabar, mas não deveriam mostra a realidade de maneira escancarada, para que os telespequitadores não fiquem chocados com tudo aquilo que esta acontecendo.

A televisão brasileira hoje está cheia de pornografia, cheia de pessoas que usam o sofrimento alheio para ganhar audiencia e assim aumentar a sua conta bancaria ou então para mostra as outras emissoras de televisão que são bons é burrice afirma que a televisão brasileira não presta, mas do jeito que a carroagem anda, vamos sentar na frente da televisão mudar de canal e ver sempre a mesma coisa.

\section{ANÁLISE}

Esse texto, mais uma vez, nos mostra que o restrito conhecimento de mundo do aluno, não adquirido, provavelmente, pelas falhas em relação às habilidades de leitura e escrita, acaba por prejudicar demais o resultado da produção, tendo em vista que se trata de um texto permeado de incoerências.

O parágrafo introdutório não deixa claro o tema da redação. Não há conectivos no texto, ou seja, o autor expõe suas ideias sem a preocupação de interligá-las.

No primeiro parágrafo, o autor, provavelmente, quis dizer que os meios de comunicação "alienam" as pessoas. No entanto, no parágrafo seguinte, não há uma retomada ou mesmo um explicação sobre tal "crítica", ou seja, temos falhas no que se refere à MR2.

Percebemos através da leitura que o autor restringe "meios de comunicação" apenas à televisão, mostrando mais uma vez seu precário conhecimento.

No segundo parágrafo, nos deparamos com uma sugestão em relação aos programas policiais. Nesse mesmo momento, o produtor insere um demonstrativo ("aquilo") que de imediato faz com que o leitor procure seu antecedente: “[...] para que os telespequitadores não fiquem chocados com tudo aquilo que esta acontecendo." Aquilo o quê? O autor não nos dá exemplos.

O problema mais grave está no terceiro parágrafo, pois fere o recurso da MR3. Praticamente todo o parágrafo mostra questões negativas referentes à televisão, mas logo a 
seguir, o produtor menciona que "é burrice afirma que a televisão brasileira não presta". Como poderia um meio de comunicação, de acordo com o autor, usar as pessoas, mostrar programas com pornografia e ainda assim “prestar”? A contradição é bastante evidente.

É importante ressaltar que o aluno teve uma fuga parcial ao tema, tendo em vista que não abordou de maneira clara os abusos do meio de comunicação e nem sequer citou a questão da liberdade de expressão.

\section{4-1}

\section{Como garantir a liberdade de informação e evitar abusos no meio de comunicação?}

É difícil garantir, porque nós brasileiros temos liberdade e ao mesmo tempo não, veja só um fato que aconteceu que deixa qualquer pessoa passada. Um dia um rapaz perguntou a uma moça onde ficava um hospital chamado laureano, ela respondeu com maior ingnórancia, vá pergunta a outra pessoa, que eu não sei. Na minha opinião, não temos liberdade o posso [oposto?] nas nossas cidades criticam muito quem não sabe nada, bom se os senhores de idade, não sabem ler o jeito e pedir informação pra alguém, mas essas pessoas que pedem informação viram abusados, chatos, por perguntarem algum, então o que devemos fazer para evitar, criar novas escolas para essas pessoas principalmente para os senhores de idade que nunca foram em uma escola.

\section{ANÁLISE}

Em redações como esta, percebemos claramente a precariedade do ensino brasileiro. $\mathrm{O}$ aluno não tem a mínima noção da estrutura de uma produção textual argumentativa. Temos a impressão de que simplesmente responde a uma pergunta e não disserta sobre o assunto. No início, nos deparamos com “É difícil garantir, porque [...]”. Se o leitor não tem conhecimento da proposta da redação fica no obscurantismo.

A oralidade é escancarada no texto, ou seja, não há uma preocupação por parte do autor em se adequar à situação requerida.

Além da desestruturação formal, há problemas no aspecto lógico-semântico. Desta forma, fica fácil localizar infrações às quatro metarregras ao longo do texto.

Há uma total desarticulação entre o texto e o tema proposto (MR4). A falha na MR2 pode ser percebida logo no início do texto, quando não é mencionado o complemento do 
verbo "garantir". A metarregra de não-contradição é infringida na sequência: “[...] temos liberdade e ao mesmo tempo não [...]".

A infração à MR1 pode ser notada em diversos momentos, como quando repete "essas pessoas" e "senhores de idade", tornando o texto bastante confuso.

Em suma, em nenhum momento o autor falou sobre os meios de comunicação. Verificamos que o precário conhecimento do aluno possibilitou um entendimento de caráter amplo da expressão "liberdade de informação", deixando, o autor, de ter qualquer consistência e cunho crítico, recaindo na fuga total ao tema.

\section{5-0}

\section{Como garantir a liberdade de informação e evitar abusos no meio de comunicação?}

Atualmente podemos observar que os meios de comunicações estão passando por vários constrangimentos, constrangimentos esses que muitas vezes interompe sua liberdade de como será que vão passar seus programas, para os telespectadores.

Devemos nus preocupar como será que vamos ajudar a sair desse problema, problema esse que cresce a cada dia.

Logo toda essa preocupação de como vamos evitar o abuso no meio da comunicação, é que precisamos usar métodos que favoreça e enriqueça passando assim ajudar a evitar mais esse tipo de constrangimento que vem ocorrendo em todos os programas.

\section{ANÁLISE}

Com relação à MR1, podemos dizer que dois casos de reiteração poderiam ter sido mais criativos, apesar de não prejudicarem o texto: "os meios de comunicações estão passando por vários constrangimentos, constrangimentos esses que muitas vezes" e "ajudar a sair desse problema, problema esse que cresce a cada dia."

Percebemos no texto analisado que o autor tem pouco conhecimento sobre o tema abordado e muitas dificuldades em argumentar. Nota-se, também, que ele restringe meios de comunicação a programas televisivos. A dificuldade em organizar suas ideias é extrema.

O autor menciona, repetidamente, a palavra "constrangimento", no entanto, não a esclarece, não explica para o leitor quais tipos de constrangimentos. 
Ainda com relação à MR1, devido à falta de organização das ideias, encontramos uma falha quando o autor procura substituir gramaticalmente a expressão "meios de comunicação" pelo pronome "sua". A substituição seria válida se o autor não tivesse usado as flexões indevidamente.

A falta de clareza permeia todo o texto. No terceiro parágrafo, quando menciona: “[...] que precisamos usar métodos que favoreça e enriqueça passando assim [...]", o leitor fica sem saber o que seria enriquecido e favorecido. Uma revisão mais criteriosa do texto poderia ajudar o aluno a se expressar com menos dificuldade.

\section{9-1}

\section{Como garantir a liberdade de informação e evitar abusos nos meios de comunicação}

Ser interessado por estudos, que tenha com desenvolvimento pela lingua portuguesa, conhecimentos com livros, em fim que seja com informativa com tudo ao seu redor.

Saber se comunicar é precisso que saiba se expressar a tudo que vá falar, ser bem desenvolvida ao usar as palavras que se refirar a algo ou alguém.

Liberdade de informação depende apenas do própio alguém que queira ser bem informativo, assim poder evitar não só abusos em se comunicar-se com alguém, com também ser sempre alguém bem comunicativo com sociedade a qual faça parte do seu meio de comunicação.

\section{ANÁLISE}

Nota-se, nesse texto, a extrema dificuldade do aluno em utilizar aceitavelmente a modalidade escrita da língua portuguesa e expressar suas ideias de maneira coerente.

É certo afirmar que o texto pode ser considerado macro e microestruturalmente incoerente.

Uma leitura global revela uma quase total desarticulação entre o texto e o tema proposto. Não há um entendimento ou conhecimento do assunto a ser abordado.

O produtor, independentemente da interpretação que faz da proposta, não introduz o mote, não deixa claro sobre o que irá falar (MR4). 
O tempo todo no decorrer do processo "dissertativo" deparamo-nos com dificuldades de interpretação devido à falta de domínio das habilidades de leitura e escrita por parte do autor, impossibilitando o leitor de apreender o real sentido do texto.

\section{8-4}

\section{Como garantir a liberdade de informação e evitar os abusos nos meios de comunicação?}

Na civilização mundial entre guerras e desencontros, exílios e quebra de artigos de lei constitucional; deixa parecer que a era monárquica voltou a predominar impedido a expedição de nossa carta de euforia perante a comunicação.

Onde as políticas de imprensa adotadas, são promovidas por enquetes de barganha que estão altamente preocupadas... em absorver os falsetes de uma política de poucos; escondendo a veracidade para a massa que tem sede de justiça e fome de liberdade. Essas que são encapuzadas à vista do pobre cidadão a quem é negado o direito de pedir justiça, dando assim impunidade e indignação.

Segundo o inciso IX do artigo $5^{\circ}$ da constituição federal de 1988 é dito: "é livre a expressão da atividade intelectual, artística, científica e de comunicação independente de censura ou licença"; são palavras que não transpareceram aos atuais governantes que tentam acoplar novamente a censura nos meios de informação, ou é melhor dizer: viva a repressão!

Sem a repressão, sem políticas de imprensa voltada, para a forma de barganha, mas sim, voltada para a total liberdade de expressão se uma forma que ainda não está sendo feita; com os Josés, Marias, Severinos, a massa trabalhadora que compõe e pede liberdade para denunciar os desenganos freqüentemente acobertados pela falsa imprensa.

\footnotetext{
ANÁLISE

Falta ao texto uma introdução clara ao tema. Com bastante dificuldade, pouco se consegue entender do primeiro período.

O texto, visto como um todo, apresenta-se desarticulado em suas partes.

Percebemos o tempo todo o emprego de noções confusas. $\mathrm{O}$ autor faz uso de certos conceitos que, além de serem inadequados, precisam ser mais bem definidos, tais como:
} 
"políticas de imprensa"; "política de poucos"; entre muitas outras palavras que não se ajustam ao que o autor escreve, desarticulando ainda mais a produção.

No primeiro parágrafo, é provável que o produtor tenha querido comparar a censura com a escravidão. No segundo, não há uma retomada sobre o que havia sido dito e outro assunto é introduzido ao leitor, que por sua vez não consegue relacionar os assuntos devido à dificuldade do produtor em se expressar de maneia objetiva.

Ainda no segundo parágrafo, o recurso da substituição (MR1) torna-se indevido, tendo em vista que o referente se encontra muito distante. Na frase: “[...] Essas que são encapuzadas à vista do pobre cidadão [...]” o pronome demonstrativo provavelmente substitui "as políticas de imprensa" do começo do parágrafo.

Também não fica claro nesse momento quem ou o que causa impunidade e indignação: "Essas que são encapuzadas à vista do pobre cidadão a quem é negado o direito de pedir justiça, dando assim impunidade e indignação".

Enfim, o posicionamento ideológico do autor apresenta incoerências argumentativas, impossibilitando o leitor de fazer uma real apreensão do que se quis dizer. A falta de domínio das principais habilidades é nítida nesse texto.

\section{8-1}

Hoje em dia a liberdade das informações vem tomando um rumo no qual pode-se gerar um caminho em volta para os problemas que isso poderá acarretar, mas no entanto o que seria da imprensa sem sua constante busca na escatidão de seus fatos, na procura de seu melhor desempenho perante as pessoas? *** é isso que leva a invasão de privacidade que hoje é uma marca negativa da imprensa.

Mas porque sentir tanto com essa invasão se nós mesmos é que de uma forma ou de outra damos esse direito a imprensa? Sem casos que são apresentados em rede nacional que chegam a ser absurdos, com o tamanho do discaramentos das pessoas que os levam até lá. Casos de família, privados a ela própria, que tomam rumo e conhecimento de massas bem maiores.

A partir do momento em que nossa lei permite a livre demonstração de tudo que se passa no mundo sem um limite de censura, não se pode pedir para que isso diminua, ou que de uma hora para outra acabe, isso seria quase imposível, sim, imposível pois na medida em 
que esse direito de expressão cresce as pessoas vão tomando decisões diferentes, o que gera conflitos de idéias entre elas.

Por isso é que se perde hoje a volta da nossa antiga censura, que deveria ser novamente posta em vigor na nossa lei, para que esses tipos de coisas não venham a tomar rumos maiores. E que ensinem primeiramente que para termos nossas informações sem abusos, devemos logo não dar a liberdade que "ela" quer!

\section{ANÁLISE}

Globalmente, podemos dizer que o texto configura-se fraco em relação às ideias e à argumentatividade.

No primeiro parágrafo, encontramos orações desconexas que dificultam o entendimento do leitor. Quando o autor menciona que "a liberdade das informações vem tomando um rumo no qual pode-se gerar um caminho em volta para os problemas que isso poderá acarretar" não nos são informados quais seriam esses problemas. Com relação ao eixo temático, a única informação que nos é dada é sobre a invasão da privacidade ocasionada pela imprensa.

O segundo parágrafo retoma a informação dada no primeiro e acrescenta outras ideias. Apesar do grau de informatividade não ser elevado, temos um bom exemplo da MR2.

Substituições positivas também podem ser encontradas no decorrer da dissertação, como quando o autor faz a substituição gramatical da palavra "casos" pelo pronome oblíquo "os" no segundo parágrafo: "Sem casos que são apresentados em rede nacional que chegam a ser absurdos, com o tamanho do discaramentos das pessoas que os levam até lá.". No entanto, o contrário também ocorre, pois muitas vezes o autor insere demonstrativos que não possuem antecedentes, como em: "A partir do momento em que nossa lei permite a livre demonstração de tudo que se passa no mundo sem um limite de censura, não se pode pedir para que isso diminua".

A conclusão do autor é justamente o oposto da reflexão que se pede na proposta. Este incita a volta da censura, ou seja, a não garantia da liberdade de informação.

\section{2-7}

Informação Sim, Abusos Não! 
Todos nós seres humanos, temos o direito à privacidade. E o que estamos vendo no nosso mundo nos dias atuais, é a falta de respeito para com a sociedade.

Os governantes de nosso país, precisam criar leis proibindo que pessoas sejam abusadas em suas próprias casas, por conta de redes de televisão, radios, revistas, que invadem residências até mesmo inocentes sem dar aumenos explicações. E o que é pior, policiais chegam em seus aposentos totalmente armados e as pessoas se tornam objetos dos mesmos; muitas vezes até poe informações falsas. Isso é o cumulo!

As pessoas do nosso país, do nosso mundo, precisam conhecer seus direitos, para que possam se defender em horas de abusos morais.

Nós, temos direito à liberdade de informações pois, nossa sociedade exige mais liberdade e menos abusos. Queremos Respeito!

\section{ANÁLISE}

Este é um texto que não apresenta dificuldades com a decodificação, apesar de o nível de informatividade ser baixo. Inicialmente, podemos chegar à conclusão de que o autor acredita que os abusos do meio de comunicação se referem apenas à invasão de privacidade.

Não há uma exposição clara sobre o tema, pois o autor, logo no segundo parágrafo, propõe soluções para os problemas que ainda não foram explicados. Conclui-se, pois, que a estrutura dissertativa não foi contemplada.

O uso de noções totalizadoras também compromete a força argumentativa do texto, pois não há um esclarecimento para o leitor sobre termos e expressões utilizados, possibilitando que o interlocutor chegue a muitas conclusões pressupostas. A exemplo disso, temos a frase: "Os governantes de nosso país, precisam criar leis proibindo que pessoas sejam abusadas em suas próprias casas". Além de o vocábulo soar pejorativo, não se sabe ao certo que tipo de abuso as pessoas sofrem. Faltam exemplos.

Ainda no segundo parágrafo, encontramos uma oração de difícil compreensão: "policiais chegam em seus aposentos totalmente armados e as pessoas se tornam objetos dos mesmos;". Talvez a palavra "aposentos", no entendimento do autor, tenha outro significado, o que pode ter causado a confusão.

A conclusão também não é satisfatória, tendo em vista que não há uma proposta concreta e sim divagações que caem no senso comum.

Enfim, o texto apresenta em toda a sua extensão lacunas textuais, as quais dificultam o ato interpretativo do leitor, por mais esforço que faça para compreender. 


\section{9-4}

\section{Como garantir a liberdade de informações e evitar abusos nos meios de comunicação}

Hoje em dia os abusos estão sendo mais frequente nos meios de comunicação mais para garantir essá liberdade temos que nos informar sobre as regra que devemos seguir bom a comunicações. Em temo de comunicação é muito importante para nós que precisamos muito dele com a sua tecnologia que esta sempre avançando com os seus professores, intelectuals, "conseudores" etc...

Com a comunicação nós podemos nos comunicar com as pessoas várias vezes por exemplo com o telefone, com rádio, com a televisão, com os correios que são pelas as carta, telex e pelo computador que é o mais usado agora pelas crianças e pelos adultos.

Com o computador nós temos a interment que leva nós a todos os lugares que nós gostaria de ver ou saber sobre algum assunto que nós entrerreça para fazer os nossos trabalhos da escola.

Com a comunicação a nossas vidas ficam mais moderna com a sua tecnologia mais tem sempre os abusos mais nós precisamos garantir o nossa liberdade por isso precisamos conversa com as pessoas para elas se conentisa dos abusos que estão passado fazendo uma palesta sobre o assunto dos abusos nos meios de comunicação.

\section{ANÁLISE}

A extrema dificuldade do autor em utilizar de maneira adequada a modalidade escrita da língua portuguesa é aparente. Além disso, o restrito conhecimento de mundo fica visível quando o produtor nos mostra que o entendimento que faz da expressão "meios de comunicação" se limita ao ato de comunicação das pessoas. As incoerências internas são diversas, tendo em vista que o autor não consegue articular suas ideias e pensamentos.

O texto está permeado de infrações às metarregras de Charolles. As tentativas de substituições (MR1), inconscientes, são ineficazes, posto que desinências e flexões são inseridas de maneira inadequadas, devido à não revisão criteriosa do texto elaborado. A exemplo disso temos o primeiro parágrafo, em que o produtor menciona: "Em temo de comunicação é muito importante para nós que precisamos muito dele com a sua tecnologia". O pronome/contração "dele" retoma, provavelmente, "comunicação", portanto, deveria ser 
flexionado no gênero feminino. Mesmo com a inferência do leitor, é difícil fazer a compreensão do final do parágrafo: "com a sua tecnologia que esta sempre avançando com os seus professores, intelectuals, ‘conseudores' etc [...]”.

Ainda no início do texto, encontramos o demonstrativo "essa" seguido do substantivo "liberdade" que não possui antecedente: "Hoje em dia os abusos estão sendo mais frequente nos meios de comunicação mais para garantir essá liberdade temos que”. De qual liberdade estaria falando?

O segundo e terceiro parágrafos em nada acrescentam; mostram mais uma vez as limitações do autor.

A alternativa do produtor para a questão do abuso, do qual nem ele tem conhecimento, seria a elaboração de uma palestra sobre os abusos nos meios de comunicação, pela primeira vez citado no texto. Somente pelo último parágrafo podemos inferir o precário desenvolvimento escolar do autor. Faltam-lhe todas as habilidades necessárias e básicas para a construção de um texto dissertativo.

\section{0-5}

\section{Como garantir a liberdade de informações e evitar abusos nos meios de comunicação}

Em nosso país já é comum a prática da invasão dos meios de comunicação, principalmente em casos de famílias de baixa renda, em que seus parentes são presos por terem cometidos crimes pequenos.

As empresas de comunicação não estão respeitando esses cidadãos humildes, que não sabem o que se passa. De medo que, representantes que não se responsabilizam pelos atos de seus jornalistas, que têm a plena liberdade de fazer o que querem. No entanto, para que possamos ter informações seja preciso desrespeitar a sociedade carente, então teremos que nos revolucionar e fazer com que os governadores de nosso país se movam no objetivo de tomarem decisões para por em prática os Direitos Universais do Homem, em que diz que todos devem ser tratados de forma igual. Contanto que, as empresas de comunicação se responsabilizem pelos problemas que tem proporcionado a sociedade de baixa renda é possível que haja um conciliamento, afim de que suas informações sejam transmitidas ocasionando dignidade consideravelmente aos afetados.

Afinal, é preciso que haja respeito entre todos e que as leis sejam cumpridas para que possamos obter informações sem que hajam abusos nos meios de comunicação. 


\section{ANÁLISE}

A introdução não deixa claro de que forma os meio de comunicação invadem a vida das famílias mais humildes.

Podemos dizer que, apesar de ser um texto sem ideias aprofundadas, há uma certa coerência macroestrutural.

O segundo parágrafo, por ser tão extenso, pode ter confundido o produtor, ocasionando alguns problemas ao texto. No entanto, encontramos um bom exemplo do uso da MR1 no início do parágrafo, quando através da substituição gramatical e lexical do pronome "esses" e das palavras "cidadãos humildes", respectivamente, retoma "famílias de baixa renda". O mesmo recurso também permitiu que a progressão (MR2) ocorresse, já que o produtor dá continuidade ao que havia mencionado no parágrafo anterior.

Logo em seguida, tendo em vista o mau uso do conectivo, encontramos um período desconexo, o qual não atinge objetivo algum: "De medo que, representantes que não se responsabilizam pelos atos de seus jornalistas, que têm a plena liberdade de fazer o que querem.".

No parágrafo seguinte encontramos uma infração à MR3: "No entanto, para que possamos ter informações seja preciso desrespeitar a sociedade carente, então teremos que nos revolucionar [...]". Percebemos certa generalização quando menciona que somente desrespeitando a sociedade carente é que obtemos informações. Outro conceito generalizante também é encontrado no momento em que o autor diz: "Contanto que, as empresas de comunicação se responsabilizem pelos problemas que tem proporcionado a sociedade de baixa renda é possível que haja um conciliamento". Nesse momento, o autor deixa transparecer que os abusos dos meios de comunicação prejudicam apenas a classe da sociedade.

O último parágrafo está bem estruturado e atende a proposta. Mas se analisarmos a produção de maneira geral, verificamos que a única solução que o produtor apresenta para o problema é "fazermos uma revolução", o que é bastante vago.

Em síntese, apesar de o texto apresentar, em determinados momentos, boa articulação, suas ideias são fracas e semelhantes às demais. 
0254167-0

\section{Imprensa}

Nos dias atuais, é quase impossível ter uma privacidade. A Mídia quer a todo tempo fatos degradantes em relação a pessoas não importa se da mais alta ou baixa classe social. $\mathrm{O}$ verdadeiro lixo via televisão está contaminando a todos não cidadãos.

A TV está cada dia mais preucupada com audiência, o que torna a televisão em meio não de divertimento, mas apelativo que busca as piores realidades e muitas vezes acabam mostrando verdadeiros ataque sanguinários o que torna-a um veiculo de coisas imprestáveis. Mas esta forma de TV está acabando.

Devido a programas contra estas "doenças televisivas", inspirados em outros paises, nós poderemos voltar a ver a televisão como veiculo de entretenimento, e ai sim, voltarmos a ser informados (como deveria ser) e além de tudo uma programação familiar, o que tanto carece o brasileiro. Queremos uma mudança... Quem sabe está próximo.

\section{ANÁLISE}

Macroestruturalmente, podemos dizer que o texto é coerente. No entanto, ao analisarmos detalhadamente, percebemos que apresenta muitas falhas.

Inicialmente, o autor problematiza a questão da falta de privacidade, mas no período seguinte limita suas ideias ao negativismo da mídia. Vemos, pois, que não há retomada do que nos é introduzido (MR1) e nem mesmo articulação entre as partes do texto (MR4).

Outro ponto que pode ser observado diz respeito ao uso desequilibrado dos requisitos de repetição. O uso automático da palavra "televisão/TV" acaba por empobrecer ainda mais o texto, que poderia ter sido revisto com uma simples releitura: “O verdadeiro lixo via televisão está contaminando a todos não cidadãos."; "A TV está cada dia mais preucupada com audiência, o que torna a televisão em meio não de divertimento, [...] Mas esta forma de TV está acabando.".

No parágrafo conclusivo, o autor nos informa que a solução para esses abusos está pautada em novos programas "inspirados de outros países". No entanto, o leitor fica sem entender, pois o produtor não explica e nem mesmo exemplifica esse tipo de programa. Além disso, é nesse momento que fica bastante evidente a pobreza argumentativa do aluno, pois apenas com a criação de um novo programa seria possível evitar os abusos do meio de comunicação? 
0254179-3

\section{Como garantir a liberdade de informação e evitar abusos nos meios de comunicação}

\section{Responsabilidade é um ato de saber ter liberdade de tudo e evitar abusos.}

Hoje em dia para se ter a liberdade de todas as informações que queremos é preciso bastante atenção pois tudo o que fazemos ou ouvimos serve de informação para nós.

Prestar atenção é um passo que damos e que muitas vezes liga casa com coisa e as vezes passam, que nós não percebemos, mais a garantia é poder saber e colocar em publico aquilo que você pensa, que você, gostaria de saber mais.

Hoje com essas informações teremos o direito de dizer aquilo que sabemos que é certo, e que estar ao nosso direito, mais que tenhamos responsabilidade de tudo aquilo que ouvimos, falamos, praticamos e etc.

A responsabilidade é um ato de saber ter liberdade para as coisas, principalmente para o mundo das informações e que com isso possamos aprender a evitar abusos no meio da nossa comunicação.

\section{ANÁLISE}

Logo no primeiro parágrafo o autor insere a dúvida no leitor sobre o que seria "ter a liberdade de todas as informações?". Esse tipo de lacuna deixada pelo autor prejudica demasiadamente seu texto, afastando o leitor, já que na escrita pressupõe-se que o interlocutor não faça interrupções para maiores esclarecimentos, ou seja, o texto deve ter a maior clareza possível.

Há, por parte do produtor, uma forte dificuldade em concatenar suas ideias e até mesmo palavras. Esse obstáculo, somado à desfamiliarização do aluno com a prática da linguagem escrita e à falta de conhecimento de mundo, culminou na elaboração de ideias vagas, repetitivas e sem reflexão.

Com a leitura do texto acima, fica difícil para o leitor saber sobre qual tema, efetivamente, o autor "tenta" dissertar. 


\title{
0254201-3
}

\section{Como garantir a liberdade de informação e evitar abusos nos meios de comunicação?}

Em primeiro lugar é preciso prestar atenção no que está fazendo, e não sair espalhando aí, para ninguém.

Porque qualquer coisa que a gente dizer, os povos já interpretam mau e sai espalhando para todas as pessoas e quando essas pessoas ficarem sabendo ficam no seu pé perguntando se é verdade que fulano disse; como foi se a gente está fazendo isso ainda, e não deixa a gente em paz até elas descobrirem o que querem.

Nesse mundo em que vivemos temos muitas pessoas gananciosas que não pode ver ninguém com nada que querem logo saber. Vida de artistas é muito bom, mas é muito trabalhoso por causa dessas imprensas, qualquer falha que você cometer aparecem na TV, na rádio em revista, devemos ter liberdade de tudo.

\begin{abstract}
ANÁLISE
O primeiro parágrafo do texto já nos surpreende pela total falta de contextualização. $\mathrm{O}$ autor nos menciona que é preciso prestar atenção, mas não diz em quê! Em seguida, alerta-nos para que não saiamos "espalhando aí para ninguém”, e mais uma vez o leitor não consegue pressupor a intenção do autor (espalhando o quê?). Se o interlocutor prosseguir sua leitura, encontrará no segundo parágrafo a explicação do primeiro.

É nítida no texto a extrema dificuldade do aluno em utilizar a norma padrão, pois se percebe que não há uma preocupação estrutural com a escrita. O autor escreve como se tivesse conversando com um amigo e não tem noção das várias linguagens e adequações a serem feitas.

O autor não faz uso dos recursos argumentativos, tendo em vista que nem o entendimento real da proposta consegue fazer.
\end{abstract}

0254222-6

Como garantir a liberdade de informação e evitar abusos nos meios de comunicação? 
A cada dia estamos recebendo informações, desnecessária e sofrendo abusos. A mídia têm como principal objetivo ganhar dinheiro, com base em qualquer tipo de informação, seja politicos, empresárial, clases baixas, famosos entre outros.

De toda essas classes a mídia consegue arrancar informações desejadas. A tecnológia está sempre ajudando, o que acontece na depois ser noticia no país e no mundo. Há pessoas que gostam de ser a noticia, outras simplesmente ignoram por ter suas informações no meio da comunicação.

Não há como evitar os abusos da comunicação que a cada dia está com mais liberdade. A comunicação está sempre atenta a tudo o que acontece, ou seja; está incontrolável, ninguém consegue escapar quando surge algo novo, que irá ser notícia no dia seguinte não dá para evitar os abusos.

\section{ANÁLISE}

Percebemos no texto que o grau de argumentatividade é bastante baixo, tendo em vista que há uma conformidade em relação ao autor em simplesmente aceitar que "não dá para evitar os abusos".

Não há problemas em relação à decodificação, apesar de o grau de informatividade não ser tão elevado.

Uma infração à MR2 pode ser verificada logo no primeiro período do primeiro parágrafo, pois o autor menciona os abusos, mas não nos diz que tipo de abuso. Em seguida, começa falando da mídia, não fazendo a retomada do que havia sido dito.

Mais uma vez, notamos que "meios de comunicação", para o autor, limita-se à televisão; e "a liberdade de informação" é entendida não como um direito do cidadão, mas como um poder dos meios de comunicação.

Desta forma, é evidente que a falta de conhecimento de mundo do aluno prejudica o desenvolvimento do texto.

No decorrer do texto, ao mesmo tempo em que há exemplos positivos de reiteração (MR1), nos deparamos com frases confusas e uso de vocábulos inadequados. A exemplo disso, temos, no terceiro período do segundo parágrafo, a substituição gramatical de "pessoas" pelo pronome "outras". No entanto, no segundo período do terceiro parágrafo encontramos o uso indevido do substantivo "comunicação": "A comunicação está sempre atenta a tudo o que acontece". A comunicação é o ato ou efeito de comunicar, por isso, o mais adequado seria "os meios de comunicação". 
A conclusão, como já mencionado, não propõe alguma solução, mas apenas aceita, pacificamente, os abusos dos usos de comunicação.

\section{1-5}

Podendo observar os anúncios e os comerciais de hoje em dia, vemos que uma boa parte deles não enganosos, onde por meio de propagandas, fazendo com que os telespectadores se iludam, acreditando ele em tudo, atribuindo na televisão, no rádio, nos jornais e revistas em relação as mesmas não são coisas de outro mundo, mas sem saber que isso é só para chamar sua atenção promovendo e fazendo a compra do objeto, onde quando compramos, aí é que descobrimos que aquilo não passou de um engano, uma ilusão. Para evitarmos isto, devemos cobrar a verdade perante todos os comerciantes que colocam esses tipos de anuncios nos aparelhos de comunicação, mesmo sabendo que se não fizerem com tantas mentiras e ilusões não conseguiram vender os seus produtos. Quem sabe com isso podemos obter mais informações sobre o que estamos comprando.

\section{ANÁLISE}

Esse texto representa em toda sua extensão problemas em relação a sua articulação. Os desvios em nível formal, especialmente no tocante à pontuação, são graves. Não há estabelecimento de relações sintático-semânticas entre os termos e orações.

Mesmo que superficialmente, podemos notar que o texto apresenta grande pobreza vocabular, pouco conhecimento sobre o tema abordado e muitas dificuldades em relação à estruturação do texto escrito.

O texto apresenta, em todo momento, lacunas textuais, que mesmo completadas pela ação interpretativa do leitor, dificultam o entendimento do texto.

Além do restrito conhecimento de mundo do aluno, o mesmo parece não conseguir estruturar, minimamente, o seu texto. 


\section{Mídia, um elo de ligação entre a sociedade}

Hoje, precisamos estar informados sobre tudo que acontece no Brasil e no mundo. E a mídia é a responsável para que essas informações cheguem até nós.

Mas infelismente o nível de violência chegou a tal ponto que o jornalista teêm que enfrentar muitos absurdos em sua carreira, estando sujeitos a serem mortos, porque estão tentando passar informações, ou seja, tentando trabalhar como qualquer outro ser humano.

E é por causa disso que eles invadem casas, e acabam invadindo a privacidade de famíias que "às vezes" não tem ligação com sua violência, que acabou chegando tanto aos bairros de classe baixa quanto aos bairros de classe alta.

Enfim, a mídia é uma transmissora de informações, podendo ser essas informações reais ou até mesmo para criticar a vida das pessoas menos favorecidas.

\section{ANÁLISE}

Macroestruturalmente, o texto apresenta coerência, não oferece muitas dificuldades de decodificação.

Inicialmente, encontramos uma boa, apesar de breve, introdução ao tema. No entanto, a partir do segundo parágrafo, começamos encontrar algumas inadequações no que se refere aos requisitos de coesão e coerência. A partir desse parágrafo, não há progressividade, tendo em vista que o autor não retoma o que foi mencionado anteriormente e insere novas ideias, as quais não têm relação alguma com as anteriores.

No terceiro parágrafo, encontramos um problema em relação à aceitabilidade do leitor, pois o produtor acredita que "invadir casas" e a "privacidade" alheia faz parte do trabalho do jornalista e pode ser considerado algo aceitável.

Espera-se que o autor mencione sobre os abusos dos meios de comunicação e a liberdade de informação, mas este encaminha suas ideias para outra direção. Vemos, pois, que a falta de domínio das habilidades de leitura e escrita no autor o impossibilitam de atingir seu objetivo. 
0254262-5

\title{
Como garantir a liberdade de informação e evitar abusos nos meios de comunicação
}

A informação deve ser vista de maneira sabia para não tira as suas vantage, para que não acha abuso, no meio da comunicação e que possa ser uma informação boa para ler. E não falando das pessoas e aumentando seu conteúdo original.

Uma informação, falando dos acontecimentos e fato da realidade, da mais inbusso [impulso] e fontade [vontade] de se ler. E de ter a sua liberdade de informação.

Porque mos [nós] plecisamos [precisamos] esta por dentro do acontecimento para está bem, informa do do que acontece no dia, a dia e de ser um pessoa bem informada.

E que a formação não possa atrapalha o meio de comunicação e que fasa a comunicação ser mais valorizada no meio da informação.

\begin{abstract}
ANÁLISE
Mais uma vez, é possível verificar através dessa redação que o conhecimento de mundo do aluno é bastante restrito, bem como sua formação escolar. Há uma grande dificuldade em argumentar e até de relatar fatos que estão visíveis na proposta. O tema, para o produtor, limita-se em divagar sobre as informações que as pessoas recebem no dia-a-dia.

O requisito da MR1 não é empregado de maneira satisfatória, já que no decorrer do texto o autor utiliza a palavra "informação" diversas vezes.

A conexão das ideias e orações é quase que imperceptível e, por mais esforço que o leitor faça, é difícil compreender o que o produtor do texto tentou transmitir.
\end{abstract}

\section{6-8}

\section{TEMA: Como garantir a liberdade de informação e evitar abusos nos meios de} comunicação?

Os meios de comunicação tem ocupado um espaço muito amplo em nossa sociedade, nós não podemos sair de nossas casas; expressar uma ideia, que logo nos somos vistos por todos. 
Eles não nos deixam em privacidade no trabalho, em casa ou na rua; a qualquer momento podemos ser filmados, fotografados e etc.

Eles tambem servem para nos informar sobre o que acontece no nosso pais e no mundo, mas para tudo lá o seu limite; deve-se estabelecer um limite para eles como garantia de liberdade, para podermos, andar, correr, gritar e fazer o que "quizer" dentro dos limites estabelecidos, sem ser vistos por todos, porque uma das coisas que mais precisamos e a liberdade e a privacidade.

\section{ANÁLISE}

Podemos inferir que o entendimento sobre a garantia de liberdade limitou-se na noção totalizante do termo liberdade, o que possibilitou ao produtor muitas restrições ao expor suas ideias.

O recurso da MR1, quando empregado, teve pouca efetividade. O segundo parágrafo é iniciado com um pronome pessoal, fazendo com que o leitor procure seu antecedente. Obviamente, se estivermos atentos, veremos que se refere a "meios de comunicação", no entanto, temos o pronome "todos" muito mais próximo, o que pode confundir o leitor desatento.

A falta de criatividade é mais uma vez notada quando o autor reitera o pronome "Eles", no terceiro parágrafo.

É importante observar que o produtor utiliza o termo "meios de comunicação" de maneira genérica, principalmente quando menciona: "Eles não nos deixam em privacidade no trabalho, em casa ou na rua; a qualquer momento podemos ser filmados, fotografados e etc.". É nítida, neste momento, a confusão de conceitos do autor.

Uma infração à MR3 também é bastante clara no terceiro parágrafo: "deve-se estabelecer um limite para eles como garantia de liberdade”. Como poderia haver liberdade com limites?

Podemos dizer que há certa progressão entre os parágrafos segundo e terceiro, apesar de pouco acrescentar com relação à informatividade.

$\mathrm{Na}$ conclusão, o leitor se depara com divagações sobre "o que é preciso", mas não encontra argumentos plausíveis. 


\section{0-3}

\section{Conscientização}

Na época da ditadura, o Brasil perde a liberdade de expressão. Aos poucos, os artista em geral, mostraram sua resistência em forma de músicas, poemas, peças de teatro e em filmes cinematográficos. Com o passar do tempo, a censura foi aniqüilada e os brasileiros se libertaram da repressão.

Essa vitória não está sendo respeitada. Muitos dos meios de comunicação não estão preocupados em atualizar e informar o público, e sem, atraí-lo; só atraí-lo.

Nos jornais como Cidade Alerta e Brasil Urgente, as notícias sempre têm personagens em situações desesperadas e sofridas, vendendo assim, uma imagem chocante; dando o sucesso necessário: ibope. É ele que está acima da ética e da moral. São nessas horas que o brasileiro percebe que o direito de privacidade da sua imagem e da sua moral não está sendo respeitado.

O público precisa ignorar todo tipo de exploração, fazendo com que a mídia se conscientize de que a informação sem demagogia é suficiente para atraí-lo.

\section{ANÁLISE}

Apesar da falta de conexão entre os parágrafos, esse texto apresenta uma boa introdução. O primeiro parágrafo estabelece progressão (MR2) entre os períodos, que são articulados (MR4) de maneira satisfatória, tendo em vista que o autor faz uso de locuções adverbiais: "Com o passar do tempo"; "Aos poucos [...]".

Também encontramos um bom exemplo de associação no primeiro período do segundo parágrafo, em que o autor retoma a questão da censura fazendo, de maneira muito criativa, a reiteração (MR1) da expressão "se libertaram da repressão" por "Essa vitória". No entanto, o final do parágrafo deixa a desejar devido à falta de clareza: "e sem, atraí-lo; só atraí-lo".

Outro exemplo de substituição pode ser encontrado no terceiro parágrafo, em que o produtor utiliza o pronome "ele" para se referir a "ibope": "dando o sucesso necessário: ibope. É ele que está acima da ética e da mora.".

O texto é bem estruturado, embora o produtor pudesse ter aprofundado mais o tema. A conclusão apresenta acertos e desacertos. Por um lado, retoma, mesmo que superficialmente, o assunto abordado anteriormente. Por outro lado, o autor utiliza palavras com uma extensão 
de significado muito ampla, sem dar continuidade e explicações. Palavras como "exploração" e "demagogia" precisam ser definidas antes de serem exploradas como argumento para apoiar qualquer ponto de vista.

\section{1-7}

É tanta violência que perdemos a liberdade de viver de sair de casa. No nosso dia-a-dia só que assistimos e escutamos falar é sobre a vidas da pessoas que são públicas, isso é uma falta de liberdade de informação são os jornalistas nas frentes de suas casas, querendo saber de suas vidas pessoas. Para que acha liberdade informação as pessoas ter serem mais discreta consigo mesma.

Na televisão só o que passa é falando dos principais acontecimentos, infeslizmente entre eles está a violência que é muito comum no nosso cotidiano. Muitas vezes é bom mostrar a violência como ela está para ficarmos informados do que está acontecendo no mundo.

Os abusos nos meio de comunicação são censura das novelas, que passa em horários não apropriados isso sim é um abuso aos telespectadores, passa tanta mulher nua. Para evitar deveria não dever existir passar isso em programa nenhum.

\footnotetext{
ANÁLISE

Uma leitura superficial já nos possibilita perceber que o produtor do texto não consegue articular as palavras que escreve. Os problemas referentes ao domínio de habilidades básicas são claramente notados, o que incide no aspecto lógico-semântico do texto.

Há uma total desarticulação entre o texto e o tema proposto. Apenas no último parágrafo é mencionado que: "a censura das novelas são abusos dos meio de comunicação".

O tempo todo o leitor se depara com sequências mal construídas. Desta forma, o texto apresenta sérios problemas de coerência, segundo às metarregras de Charolles, que repercutem na estruturação deficiente do conteúdo.
} 


\title{
$0254341-9$
}

Os meios de comunicação tem como objetivo mostrar os acontecimentos ligados com o mundo e ao redor dele. Com isso vem mostrando divercidades em temas que não era para ser discultidos em prógramas de rádio ou televisão no horario comercial, tendo em vista jovens, crianças, adulto e pessoas de diversos estados civis em busca de temas que possam emrriquecer o seu vocabulario de informações no entanto so servem para mostrar acontecimentos banais e sem fundamentos que não esteja ligados com o dia-a dia das pessoas tendo em vista predominações que fazem parte do tema discultido no mundo inteiro.

E podemos evitar los não vendo ou escutando programas que não faz parte no nosso contesto historico.

\begin{abstract}
ANÁLISE
As dificuldades em expor as ideias, articulá-las e dividi-las, estruturalmente, são extremas. O primeiro parágrafo, mesmo com uma extensão bastante demarcada, não apresenta pontuação suficiente para que em uma primeira leitura o interlocutor possa apreender alguma informação relevante.

O uso restrito de elementos de coesão, a pobreza vocabular, o pouco conhecimento do tema abordado e as dificuldades em relação à estruturação do texto escrito possibilitaram a construção de frases desconexas e na maioria das vezes sem sentido.

Os argumentos simplistas e sem fundamento, na conclusão, nos mostra mais uma vez a precariedade do ensino atual e a falta de capacidade de reflexão dos alunos. Um exemplo disso pode ser retirado do último parágrafo, quando o autor menciona que "podemos evitar los não vendo ou escutando programas que não faz parte no nosso contesto historico", contradizendo até mesmo o mundo real. Como poderiam os programas transmitidos, no contexto do leitor, não fazerem parte de seu contexto histórico?
\end{abstract}

\section{3-5}

Como garantir a liberdade de informação e evitar abusos nos meios de comunicação 
Quebra de sigilo, falta de compreensão, descaso, e elevada porção de protecionismo, e isso são alguns atributos rescriados aos jornalistas que levam até você em flashs ao vivo, as imagens, não tão atraentes, de perseguições policiais dentro de favelas e/ou bairros menos favorecidos.

Eles chegam, perseguem e acabam com privacidade dos moradores, expondo-os à toda população sem sequer pedir "permissão", e acabam por contribuir o medo e o preconceito já existente com estas pessoas, isto a acarreta uma má divulgação das periferias, que quase sempre são mostradas durante a noite, envolto por um clima denso e aterrorizante.

A solução pode vir da seguinte forma: que os jornalistas revejam seus princípios jornalísticos e percebam que estão agindo de forma errada, faltando respeito com os menos privilegiados, já que eles têm que trabalhar, que trabalhem com um pouco mais de dignidade para com esse povo, que eles são animais onde se pode chegar e sair filmando sem saber se é um ladrão, traficante ou mais um indivíduo marginalizado pela sociedade.

\section{ANÁLISE}

Este é um texto que não oferece dificuldades de decodificação. Podemos não concordar com algumas ideias do autor, considerá-las genéricas demais ou algo assim, mas facilmente sabemos o que ele quer dizer.

O autor inicia com exemplos do que seriam "atributos" dos jornalistas, mas não deixa muito claro o tema a ser abordado.

Uma infração à MR1 pode ser destacada no segundo parágrafo, já que acaba por prejudicar o texto, no que se refere à clareza. A substituição gramatical do substantivo “jornalistas" pelo pronome pessoal "eles" é ineficaz devido ao fato de o referente se encontrar distante. $\mathrm{O}$ autor, neste caso, poderia ter sido um pouco mais criativo. No entanto, no mesmo parágrafo, nos deparamos com um paralelismo que tem a intenção, provavelmente, de enfatizar os abusos cometidos pelos jornalistas. Apesar de não ser uma opinião aceita por todos, o autor alcança seu objetivo.

Outro exemplo satisfatório da MR1 está no segundo parágrafo, quando o autor faz a substituição lexical de "moradores" por "estas pessoas".

Enfim, há certa estruturação em relação ao texto dissertativo, mas falta ao autor conhecimento suficiente para produção de um texto com mais consistência e confiabilidade. 


\section{0-5}

\section{Melhorar o jeito de informar.}

Como garantir a liberdade de informação e evitar o abuso no meio de comunicação? Será que temos o direito de passar por cima das pessoas para realizar um bom trabalho?

A imprensa em geral no Brasil tem sem dúvida alguma livre arbítrio para mostrar não só na televisão mas em todo meio de comunição tudo o que se passa pelo mundo, se fóssemos ver so pelo fato da informação estaríamos bem informados e não teríamos do que reclamar, pois nos dias atuais são abordados diversos tipos de assuntos, para todos os gostos, mas como somos humamos e sabemos que não estamos livres de tragédias, não deveríamos deixar que nossas vidas fossem exportas do publico rompendo a barreira da informação e alcançando a curiosidade alheia que alimenta essa maneira de informar usando o sofrimento da pessoa atingida.

A informação deve sim ser transmitida, pois esse é o papel da imprensa, mas sem abusar da fragilidade da pessoa que está passando por um momento especial. Informar sem prejudicar, esse é o dever da imprensa.

\section{ANÁLISE}

Verificamos, nessa redação, uma tentativa do autor em estruturar o texto de acordo com o gênero requerido, apesar das falhas e do conteúdo fraco.

O primeiro parágrafo é elaborado através de questionamentos direcionados ao leitor, no entanto, ao lermos todo o texto, percebemos que as respostas às perguntas não são respondidas. Somente no final da produção o autor menciona que "A informação deve sim ser transmitida, pois esse é o papel da imprensa, mas sem abusar da fragilidade da pessoa que está passando por um momento especial.", sendo o grau de argumentatividade muito baixo. No que se refere ao primeiro questionamento (a cópia do tema), não encontramos referência alguma, o que nos leva a perceber uma infração à MR4, já que não há ligação entre a introdução e o desenvolvimento do texto.

O segundo parágrafo, apesar de não apresentar tantos problemas com relação à decodificação, é muito extenso e acaba por ser prejudicado tendo em vista a falta de pontuação e de elementos coesivos.

No último parágrafo, o autor procura fazer uma conclusão que, como já mencionado, tem pouca fundamentação. 
Podemos, pois, dizer que faltou ao produtor conhecimento de mundo suficiente para garantir ao texto informatividade adequada, a fim de atingir seu objetivo: persuadir o leitor.

\section{0-0 \\ Como garantir a liberdade de informação e evitar abusos nos meios de comunicação}

A sociedade atual condiciona ao indivíduo (pertencente a mesma) o dever de está sempre bem informado, "por dentro de tudo". A televisão, o rádio e os periodicos são alguns dos meios pelos quais cada cidadão tem acesso as principai notícias da sua cidade, estado, país e mundo.

Mas, como garantir a liberdade dessas informações? Qual é a qualidade que as mesmas oferecem?

Nos dias atuais percebe-se o quanto os meios de comunicação (principalmente o rádio e a televisão) estão preocupados simplesmente em: "ser líder em audiência". E devido a este fator não se preocupam com o tipo de "informação" que estão divulgando.

Os programas policíais são exemplos claros de uma programação abusiva, que intimida e provoca medo na população.

Logo, entende-se que é necessário criar-se mecanismos incentivadores a autoregulação da mídia. Tendo como objetivo: deixar as pessoas bem informadas, e proibir esses tipos de programações "enlatadas", onde exaltam o crime e a violência. Já é tempo de dar uma basta em tudo isso.

Portanto, é dever dos órgãos competentes fiscalizarem esses abusos provocados pela mídia, na sociedade atual. E dessa forma "levar os meios de comunicação a apresentarem uma programação de qualidade".

\section{ANÁLISE}

Apesar de faltar no primeiro parágrafo uma introdução clara ao tema, o texto acima não oferece dificuldades para a compreensão, deste modo, podemos dizer que pode ser considerado coerente macroestruturalmente.

No entanto, algumas falhas internas são verificáveis. No primeiro parágrafo, o autor menciona que "A sociedade atual condiciona o individuo", mas não esclarece ao leitor de que 
forma, nem mesmo cita exemplos. Temos, pois, uma ideia solta que não se relaciona com outras partes do texto (MR4). Além disso, é necessário considerar que o verbo "condicionar" pode ter uma significação muito ampla, exigindo uma definição clara.

Outra falha relativa à MR4 está na primeira pergunta do segundo parágrafo, já que não é esclarecida no decorrer da dissertação.

Bons exemplos da MR1 podem ser encontrados no texto. A exemplo disso temos a substituição lexical das expressões "dessas informações" por "as mesmas", propiciando uma fluência adequada ao texto. Isso também ocorre em: "Nos dias atuais percebe-se o quanto os meios de comunicação (principalmente o rádio e a televisão) estão preocupados simplesmente em: 'ser líder em audiência'. E devido a este fator não se preocupam com o tipo de 'informação' que estão divulgando.”.

Outro requisito adequado que podemos encontrar está no quarto parágrafo, em que se verifica uma progressão em relação ao parágrafo anterior (MR2).

O uso de conectores entre os parágrafos também possibilitou uma boa articulação entre as ideias, tal como: "logo" e "portanto".

Percebemos, pois, que apesar de faltar ao autor um conhecimento mais aprofundado do tema, é possível localizar em seu texto o uso apropriado dos requisitos de coerência, o que torna sua produção, no mínimo, aceitável.

\section{5-7}

\section{Como garantir a liberdade de informação e evitar abusos nos meios de comunicação}

A cada dia vem sendo mais frequente a falta de privacidade entre as pessoas, a causa dessa causa privasidade é muitas vezes por causa dos meios de comunicação.

Hoje em dia é comum ligar a televisão entrar e conhecer a vida pessoal das pessoas.

Os jornalistas responsáveis por saciar a curiosidade das pessoas, muitas vezes são inresponsáveis e não respeitam e nem mede os cassos em que trabalham agem muitas vezes só em busca de informações, prejudicando a vida de muitos.

Para que isso não ocorra é preciso apostar em jornalistas capacitados que trabalhem com humanidade.

\section{ANÁLISE}


Primeiramente, foi possível verificar que o conhecimento de mundo do autor interferiu de forma marcante na elaboração do texto, visto que a dificuldade argumentativa, associada à desorganização de ideias e palavras, e, ainda, a grande repetição lexical devido à pobreza vocabular, culminou na construção de um texto fraco e sem poder persuasivo.

Uma infração à MR1 pode ser claramente notada no primeiro parágrafo, quando o autor utiliza de forma desmedida a palavra "causa": "a causa dessa causa privasidade é muitas vezes por causa dos meios de comunicação.". Provavelmente, uma revisão mais criteriosa teria eliminado o problema. O mesmo ocorre com o substantivo "pessoas" e o adjetivo correspondente "pessoal": "Hoje em dia é comum ligar a televisão entrar e conhecer a vida pessoal das pessoas. Os jornalistas responsáveis por saciar a curiosidade das pessoas".

A solução para o problema dos abusos nos meios de comunicação, segundo o autor, seria "apostar em jornalistas capacitados", o que mais uma vez nos mostra a dificuldade argumentativa do autor.

\section{2-0}

\section{Como garantir a liberdade de informação e evitar abusos nos meios de comunicação?}

Através da sua capacidade de como você é ou seja: se você é uma pessoa preconceituosa, concerteza irá sofrer esse tipo de abuso através de meios de comunicação. Mas à pessoas que tem capacidade de demonstrar o seu potêncial e não demonstra, por falta de informações mas sempre tem a sua liberdade limpa.

Por isso devemos lutar até vencer em sua vida para ser uma pessoa honesta, forte, batalhadora e capacitada para enfrentar esse mundo que está cada vez mais violento, por causa de tantos absurdos que vimos, um deles é: o abuso.

Há vários tipos de abusos, o abuso criminal; é aquele em que lhe ameaça de morte, através de um meio de comunicação que é o telefone.

Mas não devemos se preocupar muito, porque existe um sábio lá em cima que está vendo tudo.

A informação hoje é muito importante para nós jovens, adolescentes e até mesmo para pessoas idosas, ter como se expressar, falar e principalmente ter uma liberdade limpa através de abusos de meios de comunicação. 
Queremos ver uma cidade um estado e um país limpo de termo de abuso, para que possamos ter nossa liberdade.

\begin{abstract}
ANÁLISE
É nítida, nesse texto, a falta de conhecimento sobre o tema proposto. Deparamo-nos, inicialmente, com uma espécie de resposta ao questionamento feito no tema. Assim, verificamos a incapacidade do autor em estruturar seu texto de acordo com o gênero.

O autor nos apresenta em sua produção várias lacunas textuais, que mesmo complementadas pela ação interpretativa do leitor, dificultam o entendimento do texto. Um exemplo disso está no final do primeiro parágrafo, em que o produtor menciona: "Mas à pessoas que tem capacidade de demonstrar o seu potêncial e não demonstra, por falta de informações mas sempre tem a sua liberdade limpa.". O que seria liberdade limpa? A expressão não é esclarecida ao leitor.

O texto não tem articulação alguma, tendo em vista que cada parágrafo fala de um assunto diferente (MR4).

Os desvios à norma são diversos e a conclusão é incompreensível. Verificamos, pois, muitos problemas com relação ao domínio de habilidades de leitura e escrita por parte do autor, além do pouco domínio da estrutura do texto escrito.
\end{abstract}

\title{
0254509-8
}

Não como garantir a liberdade de informação, pois eles é que vem a nós a procura de nossas informações, chegam de maneira absurda. Sem nos pedi permissão par que fassam suas intrevista e mostrem para a nossa população; fatos não existente e caso de muita imortância, para você.

No meio da comunicação o abuso é muito alto, pois principalmente nas eleições, com veículos de propaganda com o som acima do permitido e tarde da noite, com desculhambasão e muito mais.

Os únicos que são mantidos preservados são os ricos por possuir dinheiro, pois somos iguais a eles, os direitos deles são iguais dos nossos. Os que mais sofrem com isso são aqueles que morram surbúbio, favelas e periferias que não tem conhecimentos sobre os seus direitos, 
então os comunicadores si aproveitam desses pessoais para mostra imagens e reportagens de sofrimentos, de angústia e muito mais.

\section{ANÁLISE}

O texto surpreende, mesmo antes de uma análise mais aprofundada, pela extrema dificuldade do aluno em utilizar aceitavelmente a modalidade escrita da língua portuguesa. Os desvios em nível formal, especialmente no tocante à ortografia e acentuação são graves. Além de desestruturação formal, há problemas no aspecto lógico-semântico devido às lacunas deixadas pelo autor.

Temos um exemplo no início do primeiro parágrafo, em que o produtor menciona: "Não como garantir a liberdade de informação, pois eles é que vem a nós a procura de nossas informações". Quem seriam "eles"? Quem vem? Não há antecedente, e o leitor fica sem saber a quem o autor se refere (MR2).

Uma infração à MR3 é bastante clara no terceiro parágrafo, quando o autor menciona: "Os únicos que são mantidos preservados são os ricos por possuir dinheiro, pois somos iguais a eles, os direitos deles são iguais dos nossos.". O uso do conectivo "pois" propicia uma interpretação contrária ao que, provavelmente, o autor tenha querido passar, tendo em vista que este se iguala à classe privilegiada, a qual parece ser a única existente, contradizendo, até mesmo, o mundo real.

Além de todas essas informações e a intensa dificuldade em formar adequadamente as palavras, o autor não adota um ponto de vista, não atingindo, desta forma, o objetivo da dissertação.

\section{6-0}

\section{Como garantir a liberdade de informação e evitar abusos nos meios de comunicação?}

Nós os brasileiros, independentemente de raça ou religião, temos o direito de falar, mas cabe a nós o dever de escutar. Buscamos a liberdade de expressão, embora essa na maioria dos casos seja ignorada. Os meios de comunicação nos enriquece por seus imensos valores, sempre transmitindo-nos informações importantes no nosso cotidiano; informações essas, que tanto pode nos edificar, como também nos questionar. 
Temos o direito de dizer o que queremos, mas nossos gritos se tornam silenciosos, porque nem sempre nossas opiniões são válidas perante a sociedade. As palavras ditas não voltam jamais, por isso, nosso papel e o da imprensa em geral, é dizer o que achamos, demonstrando a verdade e cumprindo cada palavra pronunciada.

Assim sendo, podemos crescer todos juntos, lutando por justiça e igualdade, tendo dignidade de falarmos e escutarmos o que é certo sem prejudicar a ninguém.

\begin{abstract}
ANÁLISE
Essa redação não apresenta problemas relacionados à decodificação, apesar das falhas estruturais e conteudísticas.

Não nos é claro, inicialmente, o tema abordado pelo autor. Os 3 primeiros períodos do primeiro parágrafo não estabelecem relação entre si, infringindo a quarta metarregra de Charolles.

A falta de clareza também pode ser percebida em alguns momentos da escrita, como quando menciona que "Os meios de comunicação nos enriquece por seus imensos valores", no entanto, o autor não nos diz que valores são esses; não há exemplos.

A conclusão é iniciada com um conectivo favorável (“assim sendo”), embora o grau de argumentatividade seja pequeno.

Nos três parágrafos o autor repete as mesmas ideias, ficando evidente a sua falta de conhecimento sobre o tema.
\end{abstract}

\title{
0254536-5
}

\section{Tema: Como garantir a liberdade de informação e evitar abusos nos meios de comunicação?}

\section{Título: Liberdade de expressão}

A liberdade de informação e os abusos nos meios de comunicação não são fáceis de garantir, pois é devido as pessoas, e também de como elas expõe suas idéias sobre determinado fato acontecido. Já há imprensa abusa do poder autoritário, e quem acaba sofrendo com tais conseqüências, são pessoas que não têm nada haver com tal formulada história. 
Vivemos, em um mundo totalmente complementado e dominado pelo poder, onde a "grande" minoria sofre os abusos ou com a falta de garantir, seu sussego e o da sua família. Onde quem garante sua paz, são os donos do poder, e muitas vezes, nem eles, se livram desses assédios e abusos, que nunca passam longe de nós.

As pessoas têm o direito, de querer ou não, expor suas idéias, e também de querer ou não, informar sobre sua vida, seja ela privada ou pública.

\begin{abstract}
ANÁLISE
Uma leitura global do texto já nos indica o pouco conhecimento de mundo do autor e a extrema dificuldade que tem em utilizar a modalidade escrita.

O primeiro período do primeiro parágrafo está incompleto, tendo em vista que o produtor inicia uma ideia e não termina. Outra lacuna deixada pelo autor pode ser verificada no final do primeiro parágrafo, quando menciona: "são pessoas que não têm nada haver com tal formulada história.". Não se sabe de que história o autor estaria falando, já que não a mencionou (MR2).

Percebemos o uso desmedido de palavras com caráter amplo e vaga definição, como: "autoritário", "poder" e "dominado". Considera-se que palavras desse tipo precisam ser definidas antes de serem exploradas como argumento para apoiar qualquer ponto de vista. Se essa explicação não ocorrer por parte do autor, seu argumento pode esvaziar e perder seu poder de persuasão.

Verificamos, no texto, muitas expressões confusas quanto ao significado, como em: "Vivemos, em um mundo totalmente complementado e dominado pelo poder,".

Em nenhum momento nos é mencionado os abusos nos meios de comunicação, configurando uma fuga parcial ao tema pelo autor.
\end{abstract}

\title{
0254547-0
}

A TV hoje em dia não está mais respeitando mais como antes, os programas que passavam tarde agora passa cedo, crianças assiste que não deveria, os programas educacionais já estão se acabando pouca coisas se aproveita, os programas emfantil estão se acabando pouco a pouco os que restam ja não e mais como antigamente. Mais durante dessas criticas, a TV e o rádio e o meio de comunicação mais útil dentro de nossas casas nos diverte, interte e 
nos ajuda a relanar [reclamar] é [chato] jato quando semetém demais na vida dos artistas augus apresentadores não querem nem saber e fala da vida pessoal dessas pessoas sem dó.

As vezes os apresentares abusão das palavras e falam o que quer sem se preocupar que está o assistindo.

\begin{abstract}
ANÁLISE
Primeiramente, é necessário dizer que o autor desse texto limita a expressão "meios de comunicação" à televisão e seus programas exibidos.

Outro fato que deve ser apontado é a total falta de capacidade do aluno em utilizar a modalidade escrita. Os erros ortográficos e de concordância são gritantes e o texto não progride, nem flui.

A disposição de palavras e ideias do texto encontra-se mal articulada, o que dificulta a compreensão pelo leitor.

Não há parágrafo introdutório, pois o que percebemos é que o autor, desfamiliarizado com a escrita, insere uma sequência de informações, sem revisá-las.

O texto apresenta em toda sua extensão lacunas textuais, que mesmo complementadas pela ação interpretativa do leitor, dificultam seu entendimento.

A exemplo disso temos o primeiro período do primeiro parágrafo, no qual o autor menciona que: "os programas educacionais já estão se acabando pouca coisas se aproveita, os programas emfantil estão se acabando pouco a pouco os que restam ja não e mais como antigamente.". Como eram os programas de antigamente? O autor não cita exemplos.

Diversas outras passagens demonstram a desarticulação do autor, como: "Mais durante dessas criticas, a TV e o rádio e o meio de comunicação mais útil dentro de nossas casas nos diverte, interte e nos ajuda a relanar[reclamar]". O leitor não sabe o objetivo do autor ao enunciar tais frases.

Vemos, pois, que falta ao aluno o domínio das habilidades básicas para escrever um texto com coerência.
\end{abstract}

\title{
0254562-4
}

Como garantir a liberdade de informação e evitar abusos nos meios de comunicação? 
O Brasil é um país onde todos são livres para expressar o que pensam, de acordo com a Constituição Federal de 1988.

Sabemos que os principais meios de comunicação são: televisão, rádio, jornais e revistas. Que bom seria se ligássemos a TV e assistíssem as boas notícias, programas educativos, próprios para as crianças e até mesmo adultos. Infelizmente não é isso o que vemos; a televisão (principal meio de informação do Brasil e talvez do mundo) está cada vez mais banalizada: as novelas que antes só falavam em romance, hoje mostram cada vez mais cenas pornográficas entre atores, o que deixa os pais constrangidos na hora em que estas vão ao ar e seus filhos encontram-se na sala vendo-as.

Não só a televisão comete seus abusos, mas também os jornais, que não respeitam a privacidade de algumas pessoas.

Todo brasileiro tem o direito de gritar o que pensa, afinal esse é um país de livre expressão, desde que seja respeitada a privacidade de cada um.

\section{ANÁLISE}

Não encontramos problemas com relação à compreensão do texto. Embora o primeiro parágrafo seja um pouco extenso, podemos perceber que há uma boa estruturação textual.

Bons exemplos do uso dos requisitos da MR2 podem ser encontrados, embora o grau de informatividade não seja tão alto. O segundo parágrafo é prova disso. Além de fazer a retomada, mesmo que superficial, um período se refere ao outro e progride no que diz respeito a outras informações. Como exemplo, temos o demonstrativo "isso" que retoma a informação do parágrafo anterior: "Infelizmente não é isso o que vemos".

Mais uma vez, os programas televisivos são o foco do desenvolvimento dissertativo. Assim, apesar de apresentar uma estrutura adequada, o autor peca no que se refere ao conteúdo, já que somente transcreve informações do senso comum, sem nada de novo para acrescentar.

Ideias generalizantes acabam por prejudicar o teor argumentativo do texto, como, por exemplo, quando o autor menciona que a televisão é o principal meio de informação do Brasil. Temos, nesse momento, um problema em relação à aceitabilidade do leitor, que pode não concordar com o autor.

Para finalizar, faz-se necessário mencionar que a conclusão deixa a desejar pelo fato de o autor não propor uma solução para o problema, nem informar de que maneira "a privacidade" poderia ser respeitada. 


\section{3-4}

\section{Como garantir a liberdade de informação e evitar abusos nos meios de comunicação?}

Vivemos em um mundo, onde somos livres, temos o direito de ir e vir, falar etc..., mas esse direito que temos, não nos dá o poder de ultrapassar os limites. Devemos respeitar e também quando isso não acontece, devemos denunciar, reclamar, procurar nossos direitos.

Não é justo que, pensando nos lucros, na audiência de uma notícia, o próximo seja desrespeitado, não se importando com os sentimentos, e a dor dos outros. Este sensacionalismo barato só enche o lucro dos grandes empresários.

As notícias devem ser passadas ao povo, mas certas tragédias não. Quando alguém sentir-se atingido, deve procurar seus direitos, pois nossa constituição garante que assim como a atividade intelectual é livre, ela também não deve violar a intimidade, a vida privada e a imagem das pessoas, assegurando o direito de indenização por danos morais se ocorrer este tipo de violação em nossos direitos.

\section{ANÁLISE}

Primeiramente, deve-se mencionar que falta ao texto uma introdução clara ao tema.

Uma primeira infração à MR2 pode ser encontrada no primeiro parágrafo, quando o autor menciona que "esse direito que temos, não nos dá o poder de ultrapassar os limites". No entanto, não nos é explicado que limites são esses, não há exemplos.

Em nenhum momento, o aluno insere o termo "meios de comunicação" em sua redação, o que acaba por não deixar muito claro as referências que faz. A exemplo, temos o trecho a seguir: "não se importando com os sentimentos, e a dor dos outros". Quem não se importa? Se o tema não fosse levado em consideração, seria praticamente impossível saber a quem se refere.

O texto é compreensível, apesar de em alguns momentos apresentar incoerência nas correspondências entre as palavras, como quando menciona "[...] Só enche o lucro de grandes empresários"; talvez o mais adequado seria utilizar: "aumenta o lucro".

Bons exemplos de uso da MR1 são encontrados, como quando cita: "assim como a atividade intelectual é livre, ela também não deve violar a intimidade". Percebemos a substituição gramatical de expressão "atividade intelectual" pelo pronome "ela". No entanto, 
devido à falta de argumentatividade e pouco conhecimento do tema, esse requisito não pôde ser tão positivo.

\section{3-9}

Com a tecnologia avançada nos dias de hoje, fica cada vez mais difícil não ser alvo da mídia. Muitas vezes, os jornalistas não sabem ao certo o que se passa e acabam fazendo, e publicando uma reportagem diferente do acontecimento. Eles acabam fazendo suas próprias deduções sobre o fato ocorrido.

Geralmente, quem sofre mais nas mãos da mídia são os famosos. Pelo fato, de serem populares a mídia chega até espioná-los.

Ainda não há, totalmente, um meio para garantir a liberdade de informações, porque todos somos alvos para falatório. A única alternativa a se fazer é nos cuidarmos ao máximo, no que pudermos, para evitar que os outros e, às vezes, até mesmo a mídia falem de nós.

Enfim, a mídia, muitas vezes, acaba sufocando as pessoas. Principalmente, os famosos. Não importa se falam bem ou mal da pessoa, mas elas acabam ficando "mal no fato" e ficam bravas com a imprensa. Mas, convenhamos... com toda razão!

\section{ANÁLISE}

É nítida, na redação, a falta de conhecimento sobre o tema abordado. Além do autor limitar "os abusos" à falta de privacidade das pessoas, principalmente "dos famosos", verificamos que não há uma real compreensão do termo "liberdade de informação".

Apesar de o texto não apresentar muitos problemas com relação à ortografia e estruturação, pode-se perceber que o grau informativo-argumentativo é muito baixo.

Falta ao autor conhecimento de mundo suficiente para adquirir um ponto de vista e persuadir o leitor com informações relevantes.

No que se refere às metarregras, podemos encontrar alguns exemplos positivos. $\mathrm{O}$ primeiro parágrafo apresenta bom uso do requisito da MR1, em que o autor utiliza o recurso da elipse e substituição gramatical. A elipse pode ser notada antes do verbo "acabam", o qual retoma "os jornalistas": "os jornalistas não sabem ao certo o que se passa e acabam fazendo [...]". No período seguinte, o autor substitui “jornalistas" pelo pronome "Eles", o que acaba dando ao texto uma determinada progressividade (MR2). 
Ainda no primeiro parágrafo, a pobreza vocabular pode ser notada quando o autor repete dois vocábulos em períodos subsequentes, um exemplo de infração à MR1, contrariamente aos exemplos anteriores.

Enfim, é um texto com articulação adequada. Verificamos bons exemplos de conectores como: "geralmente", “porque”, “mas", “enfim”. No entanto, o autor peca pela falta de argumentatividade e de ideias concretas.

\section{3-6}

\section{"Mais privacidade e menos sensacionalismo"}

Vivemos em um mundo totalmente informatizado, os meios de comunicação estão sempre inovando com as mais diversas informações para deixar todos nós cada vez mais atualizados sobre tudo o que acontece no nosso planeta.

Em função de trazer cada dia informações atualizadas e novidades aos telespectadores, as emissoras, imprensas e redes jornalísticas acabam invadindo a privacidade das pessoas atrás de sensacionalismo para a midia; algo que acaba tirando a liberdade de muitos principalmente das pessoas de classes baixas.

A maioria dos jornalista tiram proveito fazendo reportagem em favelas e na casa de pessoas pobres, para assim tentar aumentar o seu Ibope sensibilizando a nós telespectadores com a desgraça, e a pobreza dessas pessoas:

A midia aproveita o seu grande poder, as sua camêras e abusam da intelectualidade para tentarem ser superior as famílias simples, invadem a casa dessas famílias atrás de algum parente ladrão, ou até de alguns vizinhos que já foram culpado por estupro.

A nós só nos resta esperar por alguma atitude mais digna, afinal se são os jornalistas que transmitem, ao mundo as imagens do nosso Brasil, porque não mostrarem as belezas de nosso país ao invés de simplesmente a pobreza, a miséria e a violência? Somos parte de um pais que merece ser digno de suas belezas!

Queremos ligar a televisão e ver as coisas boas que este país tem a nos oferecer e não familias sendo questionadas sobre parentes, vizinhos ou amigos que tenham participado de algum ato de violência.

Todos nós merecemos um resultado mais atraente do trabalho dos nossos jornalistas!

Precisamos de mais privacidade e menos sensacionalismo. 
Este é um texto que não oferece dificuldades de decodificação. O leitor pode não concordar com algumas ideias, mas com facilidade pode compreender o que o autor quer dizer. Em um texto assim, é possível localizar o uso adequado dos requisitos de coerência.

A boa estruturação textual é resultado da articulação das ideias e partes do texto (MR4). A progressão (MR2) encontra-se bem trabalhada no segundo parágrafo, em: "Em função de trazer cada dia informações atualizadas e novidades aos telespectadores, as emissoras, imprensas e redes jornalísticas acabam invadindo a privacidade das pessoas atrás de sensacionalismo", que retoma adequadamente o que foi mencionado na introdução, criando, desta forma, um sequenciamento do pensamento. Logo em seguida, deparamo-nos com as consequências "das novas informações", o que se torna, no nível da expressão, a introdução de novas informações.

A metarregra de repetição (MR1) é usada sem exagero, caracterizando a manutenção temática. Desta forma, palavras e expressões que fazem parte do desenvolvimento do assunto se repetem sem prejuízo para o texto: "informações", "mídia”, "jornalistas".

Apesar do autor não dissertar sobre a "liberdade de informação", limitando-se aos abusos, no que diz respeito à coerência, temos um texto praticamente incontestável. É evidente que não se trata de um texto perfeito, principalmente no que se refere às ideias e ao poder de argumentação, mas revela uma considerável força de articulação lógica do pensamento.

\section{1-9}

\section{Liberdade de Informação: bom ou mal?}

Os meios de comunicação são muito importantes. Mas nem sempre são usados adequadamente. Por quê?

Muitos jornalistas vivam das desgraças alheias para garantir o ibope de seus programas. Com isso invadem lares de pessoas humildes sem conhecimento de seus direitos e se deixam levar pela conversa doce dos jornalistas, que falam que estão ali para ajudar. E quando vêem já se tornaram alvo de discussões em programas sensacionalistas.

Claro que todos devemos saber o que se passa ao nosso redor, mas não usar da ingenuidade das pessoas para garantir a audiência de seus programas. 
E para mudar isso, teria que ser cumprida a lei e punisse quem usasse a imagem sem autorização. E esse povo humilde que procurasse aprender mais sobre seus direitos e fazê-los valer!

\section{ANÁLISE}

Esse texto, embora não esteja satisfatório no requisito de argumentação e contenha pouca relevância informativa, pode ser compreendido com facilidade.

Há uma introdução clara ao tema, apesar de bastante breve. Além disso, o uso adequado da MR2 pode ser identificado no segundo parágrafo, em que encontramos a "resposta" da questão deixada na introdução: "por que nem sempre os meio de comunicação são usados adequadamente? Porque muitos jornalistas vivem da desgraças alheias para garantir o ibope de seus programas".

Ainda no segundo parágrafo, encontramos uma infração à MR3, quando o autor menciona: "Muitos jornalistas vivam das desgraças alheias para garantir o ibope de seus programas. Com isso invadem lares de pessoas humildes sem conhecimento de seus direitos e se deixam levar pela conversa doce dos jornalistas, que falam que estão ali para ajudar.". Da maneira que está escrito, o leitor pode se confundir e questionar: "os jornalistas invadem os lares e se deixam levar pela doce conversa de jornalistas"? Há uma incoerência total, que pode ter sido causada pela falta de revisão do texto, pois não ficou claro o referente de "se deixam", que pode ser tanto "os jornalistas" quanto "pessoas humildes".

Percebemos que o autor, em diversos momentos faz confusão das pessoas gramaticais, já que ora emprega a primeira pessoa do plural, ora a terceira: "Claro que todos devemos saber o que se passa ao nosso redor, mas não usar da ingenuidade das pessoas para garantir a audiência de seus programas.".

No parágrafo conclusivo o autor menciona que "para mudar isso, teria que ser cumprida a lei”, no entanto, não especifica que lei é essa, causando uma espécie de infração à MR2.

Portanto, podemos dizer que o texto macroestruturalmente apresenta lógica, mas internamente são encontradas várias falhas no que se refere à coerência.

\section{5-9}


No Brasil e nos demais países do mundo, os variados programas de televisão e rádio, apresentam suas matérias cada vez mais interessantes, trágicas e algumas vezes até engraçados, para satisfazer a curiosidade dos telespectadores, para satisfazer a curiosidade dos telespectadores e ganhar mais credibilidade dos seus telespectadores. E para isso a imprensa não mede esforços.

$\mathrm{Na}$ maioria das vezes ela chega intrevistando todo mundo, sem mesmo a autorização dos intrevistados, não permitem nem que ele decida se vai ou não dar a informação; por muitas vezes esses lares são de pessoas humildes, analfabetos, que não conhecem seus direitos, e pensam que são obrigados a responder o que perguntam-lhes, isso chama-se "abusos nos meios de comunicação".

Os cidadãos mais humildes tem o direito de responder ou não à imprensa, apesar deles não saberem disto, todo cidadão deve garantir sua liberdade de informação, a imprensa deve respeitar seus direitos e não violar sua privacidade.

A imprensa busca matérias diversificadas, diferenciadas, cada vez mais apavorantes e algumas engraçadas! E não se importa em “como conseguir?”. Eles vão invadindo e gravando o que querem, o necessário para conseguir um "ibope" alto, e assim se superar; e as principais vítimas dela são os cidadãos mais humildes.

\section{ANÁLISE}

Foi possível verificar, de imediato, que o restrito conhecimento de mundo do autor e a possível desfamiliarização com escrita interferiram de maneira marcante na elaboração do texto. Além disso, notamos o uso desequilibrado dos requisitos de repetição (MR1) e a falta de progressão (MR2). O uso automático de vocábulos ligados ao tema acabou por empobrecer o texto. A exemplo, temos a palavra "imprensa" que poderia ter sido substituída por outra, tendo em vista o grande campo semântico que abarca.

Outro exemplo de repetição, causada desta vez pela falta de atenção e revisão do texto, encontra-se no primeiro parágrafo, em que o autor coloca: "para satisfazer a curiosidade dos telespectadores, para satisfazer a curiosidade dos telespectadores e ganhar mais credibilidade dos seus telespectadores".

Um aspecto de suma importância é o fato de o texto estar permeado de infrações à MR1, pois o produtor, diversas vezes, ao fazer as reiterações, acaba por mudar os antecedentes, através de flexões (de gênero e número) e desinências indevidas. No segundo 
parágrafo, por exemplo, o pronome "ela" substitui "imprensa" (corretamente). No entanto, logo em seguida, utiliza o verbo na terceira pessoa do plural, causando incoerência ao trecho: "Na maioria das vezes ela chega intrevistando todo mundo, sem mesmo a autorização dos intrevistados, não permitem nem que ele decida se vai ou não dar a informação".

No final desse mesmo trecho, encontramos um pronome pessoal que não tem antecedente, deixando mais uma vez o leitor no obscurantismo. Em seguida, o pronome demonstrativo "esse" seguido do substantivo "lares" aparece sem, no entanto, ter sido citado antes, configurando mais uma vez um termo sem articulação lógica em relação às outras ideias.

O último parágrafo é uma repetição escancarada de tudo o que o autor falou anteriormente. Desta forma, podemos dizer que o emissor repete as mesmas ideias em praticamente todo texto, não bastasse a falta de organização das ideias e conhecimento estrutural do gênero.

\section{6-7}

\section{A imprensa deve ser controlada}

Atualmente a imprensa brasileira não está tendo um respeito apropriado para com as pessoas, expõem notícias as quais até mesma chegam a prejudicar certas pessoas.

Por exemplo, quando acontece um sequestro a imprensa não está preocupada em proteger e resguardar a família da vítima, logo querem mostrar a sua dor, o preço a ser pago pelo resgate e não entende que isso é muito pessoal, tudo bem que o papel da imprensa é divulgar o que acontece no mundo, mas às vezes ela abusa, chegando até prejudicar certas pessoas envolvidas.

Às vezes, a imprensa não está preocupada com as pessoas e sim com o IBOPE que terão as notícias e para isso ser controlado, deve ser criado um programa do governo federal, para que observe com cuidado a imprensa e esta deve apresentar ao programa o que vai exibir para que não abuse em suas notícias e reportagens e ninguém saia prejudicado por isso.

A imprensa então deve ter mais cuidado ao divulgar suas notícias e estas, por sua vez, devem ser verdadeiras e convincentes e este programa deve fiscalizar, deve ser sério e justo para com as pessoas e com a imprensa. 
Percebemos, nesta redação, uma fuga parcial ao tema, já quem em nenhum momento o autor menciona a questão da liberdade de informação.

A falta de conhecimento sobre o assunto abordado e a dificuldade com relação à argumentação podem ser facilmente verificadas no texto. A intensa repetição da palavra "imprensa" (MR1) demonstra de maneira clara a falta de vocabulário do emissor. Apesar de ter havido uma tentativa de manutenção temática, a repetição propriamente dita acaba por empobrecer o texto.

A repetição de ideias também é nítida no texto, pois o primeiro e segundo parágrafos informam os mesmos pensamentos, sem haver progressão significativa. Até mesmo o final dos parágrafos é semelhante: “chegam a prejudicar certas pessoas." e "chegando até prejudicar certas pessoas envolvida.".

Ainda com relação à MR1, encontramos algumas inadequações. No segundo parágrafo, o autor utiliza o recurso da elipse para reiterar a palavra "imprensa", no entanto, ao fazê-lo troca a pessoa gramatical, mudando a desinência do verbo, causando incoerência ao texto: “imprensa não está preocupada em proteger e resguardar a família da vítima, logo querem mostrar a sua dor".

Podemos, pois, dizer que o texto, apesar de não apresentar tantos desvios em relação à ortografia e acentuação, tem pouco grau de informatividade e minimamente persuade o leitor.

\section{0-3}

\section{Como garantir a liberdade de informação e evitar abusos nos meios de comunicação?}

Éssa é uma questão na qual ninguém pode dizer-se excluído.

Todos corremos o risco de ser julgado por algo que fizemos ou não, ou também por querer ou não expor idéias.

Temos direito, e talvez até "dever" de estarmos bem informados sobre algum assunto, mas quem irá nos garantir que a maneira como estamos recebendo a informação é correta ou se está apenas "beneficiando" o interesse de quem à proporcionou?!

"Hoje somos vigiados por todos os ângulos, mas também temos nosso direitos e esses têm regras, e como tudo que tem regras, que a violar, será punido". 


\begin{abstract}
ANÁLISE
Verifica-se, inicialmente, que o restrito conhecimento de mundo do emissor interfere de forma marcante na elaboração do texto, visto que a dificuldade argumentativa associada à desorganização de ideias (e falta destas) culminou na construção de um texto superficial e fraco.

O parágrafo introdutório não esclarece o tema a ser abordado e deixa grandes lacunas ao leitor por não fazer a adequação do texto ao contexto: "Éssa é uma questão na qual ninguém pode dizer-se excluído.". O emissor considera o tema parte estrutural do texto. Desta forma, inicia a produção como se estivesse respondendo a uma pergunta. $O$ pronome demonstrativo não possui antecedente, causando incoerência ao texto.

As ideias do autor são bastante limitadas. O segundo parágrafo é uma espécie de infração à MR4, já que não possui conexão com os outros parágrafos.

Desta forma, podemos dizer que a produção não progride em termos conteudísticos e argumentativos devido ao restrito conhecimento de mundo do autor e desconhecimento da macroestrutura.
\end{abstract}

\title{
0273239-4
}

As informações devem ser expressas de forma liberal e correta sem que agrida a população e sem que haja excesso de fatos, ou seja, sem que haja o aumento do fato para não tornar a notícia errada ou ilusória.

As informações devem ser expressas de forma clara e objetiva pois só assim não ser confusa e incompreinsível.

Deve haja testemunhas certas e sérias que possam relatar tudo com validade.

Na minha opinião, deve haver menos mídia e fama e mais professionalismo e ética para que novamente, não iluda ou não esconda os fatos que por motivos de força maior não são posto em direção com intenções de abreviar ou deixar por isso mesmo o caso em questão.

Também que não haja noticias vagas sem fim da noticia ou, as vezes, sem explicar o porque do caso.

\section{ANÁLISE}


Verificamos, nesse texto, que o autor tem grande dificuldade em expressar suas ideias de maneira satisfatória.

A desestruturação formal e falta de organização dos pensamentos diminuem ainda mais o poder de persuasão do texto.

Inicialmente, notamos que o autor não contextualiza suas informações, não mencionando, por exemplo, a "quais tipos de informações" se refere: "As informações devem ser expressas de forma liberal e correta sem que agrida a população". Ainda nesse exemplo, não fica claro ao leitor o real significado da expressão "de forma liberal e correta". Além disso, o vocábulo "correta", nessa situação, parece genérico demais, precisando a palavra ser definida (e exemplificada) antes de ser inserida como argumento. É necessário dizer, também, que o que é correto para o autor pode não ser para o interlocutor (aceitabilidade).

O segundo parágrafo, além de apresentar vários desvios à norma, não progride em relação à informatividade, infringindo à MR2.

O terceiro parágrafo é uma infração clara à MR4, tendo em vista que não se articula com os outros parágrafos: "Deve haja testemunhas certas e sérias que possam relatar tudo com validade.". Além disso, as ideias do parágrafo se encontram bastante confusas. Não há explicação por parte do autor sobre a referência do termo "tudo", o qual foi utilizado.

O início do terceiro parágrafo principia-se com um recurso de caráter pessoal, o que não é permitido por esta modalidade escrita: "na minha opinião [...]”. Ainda nesse parágrafo, podemos encontrar muitas ideias confusas, promovendo lacunas textuais que, mesmo complementadas pela ação interpretativas do leitor, dificultam o entendimento do texto. A exemplo, temos o momento em que o emissor menciona "com intenções de abreviar ou deixar por isso mesmo”, mas não nos explica “abreviar o que”.

A conclusão também acaba por cair no obscurantismo, pois além da expressão "noticias vagas" não ser esclarecedora, o parágrafo insere ideias totalmente desarticuladas aos anteriores (MR4).

\section{8-0}

\section{Sem censura e se abuso}

A liberdade de expressão é lei, em outra palavras, está escrito na Constituição que todos tem o direito de expor suas opiniões. Mas o fato que deveria ser benefício para todos, vem fazendo de muitas pessoas vítimas dos meios de comunicação. 
A imprensa e os meios de comunicação em geral, esqueceram que tem como dever informar e que o seu principal objetivo deve estar relacionado ao meio jornalístico. Atualmente, o principal objetivo da mídia é dar enfoque a fatos polêmicos, fofocas, tudo que esteja relacionado ao mundo artístico.

A expressão é livre, mas todas as pessoas tem direito a uma vida privada, ou melhor, tinham, pois qualquer problema familiar, é agora assunto para ser tratado em programas de fim de tarde.

Com isso, é possível perceber que há muita coisa a ser "ajustada" nos meios de comunicação, mas que há maneiras de evitar esses abusos, as pessoas só tem que se conscientizar que também existe uma lei que a protege contra qualquer dano, seja material ou moral.

\footnotetext{
ANÁLISE

Temos, no texto, uma boa introdução ao tema proposto, embora pudesse ter sido mais bem escrita.

O segundo parágrafo, embora apresente uma parcela de progressividade, peca ao fazer a repetição automática de palavras, quando, por exemplo, finaliza o primeiro parágrafo e inicia o segundo, utilizando a expressão: "meios de comunicação". Essa infração poderia facilmente ter sido evitada se o autor tivesse revisto o seu texto e tivesse um pouco mais de criatividade.

Mais uma vez notamos que o emissor limita o termo "meios de comunicação" à televisão e sua programação, afetando, desta forma, o desenvolvimento textual, tendo em vista que faltam ao texto ocorrências de informações menos previsíveis.

Com relação ao quarto parágrafo, percebemos a tentativa de conclusão por parte do autor. No entanto, a proposta que ele tem para nos oferecer limita-se à "conscientização das pessoas" sobre o assunto, não havendo concretude nem embasamento. Além disso, podemos evidenciar, neste último parágrafo, a falta de conectivos para interligar orações e pontuação inadequada, o que acaba por prejudicar a leitura do texto.

Enfim, trata-se de um texto macroestruturalmente coerente, mas isento de informatividade diferenciada, pois o que é dito no decorrer da dissertação é de conhecimento da maioria das pessoas.
} 


\section{1-5}

\section{Como garantir a liberdade de informação e evitar os abusos nos meios de comunicação?}

Procurar ler mais nos informar, buscar melhorar mais nossa cultura e conhecimentos. Dando o primeiro passo para mudança adiquirindo conhecimentos medindo no que poderiamos tirar de bom para melhorar nossas vidas, não "engolindo" qualquer programa mostrado em televisão.

Temos sim que garantir a liberdade de informação mas uma informação de qualidade, conhecimento e cultura não permitindo os abusos que vem sendo mostrado nos meios de comunicação que não estão se importando em que estão nos prejudicando mas sim no por que estão fazendo.

Para conseguirmos melhorar as condições dos meios de informação e comunicação, não devemos abrir as portas para deichar entrar informações sem qualidades para não prejudicar ainda mais a nossa cultura.

Assim lutando por qualidade podemos melhorar e garantir um futuro melhor com liberdade de informação e comunicação de qualidade.

\section{ANÁLISE}

Inicialmente, podemos perceber que o produtor não tem conhecimento mínimo sobre a estrutura do gênero, tendo em vista que inicia o texto com uma resposta à pergunta que foi feita no tema. A limitação do termo "meios de comunicação" à televisão, por parte do autor, é bastante clara, mostrando-nos como seu conhecimento de mundo é restrito.

Não temos, pois, um tema claro no parágrafo introdutório, pois somente nos são apresentadas "sugestões" de como garantir a liberdade de informação e evitar os abusos.

O segundo parágrafo não tem progressão, decaindo numa infração à MR2, haja vista que suas informações são praticamente as mesmas do primeiro parágrafo. O mesmo ocorre com o terceiro parágrafo.

A falta de clareza e termos vagos e/ou genéricos demais prejudicam o texto no que diz respeito à coerência. A exemplo, temos o segundo parágrafo, em que o emissor afirma: "que não estão se importando em que estão nos prejudicando mas sim no por que estão fazendo.". Logo, vem ao leitor a pergunta: “fazendo o quê?”. O autor não nos esclarece.

As respostas sem fundamento e concretude enfraquecem ainda mais o poder de persuasão do texto. 
Em suma, o autor repete as mesmas ideias em praticamente todo o texto e apesar de tentar propor uma alternativa para o problema, não o faz com propriedade.

\section{0-4}

\section{O jornalismo}

O jornalismo é uma boa profissão para seguir, mas existem jornalistas que não respeitão as pessoas de baixa renda que vivem nas favelas ou em areas isoladas e de riscos, pois quando descobrem atravél de suas gentes ou pelo rádio da policia algum caso vão atrás não importando quem for, desrespeitando a constituição brasileira, mas não há como controlar o jornalismo pois também é contra a constituição, quer dizer contra a liberdade de imprensa, mas hoje há projetos para regularizar este impasse.

Atualmente o governo está tentando implantar uma lei para fiscalizar a imprensa, mas esta gerando varias discussões na sociedade, pois, como pode-se considerar uma notícia de mal gosto ou ainda com a intenção de prejudicar alguém.

Há reportes que descobrem um traficante escondida na favela, ou que uma pessoa de baixa renda comete algum furto, lá esta ele fazendo uma grande reportage.

No artigo 5 da constituição que deve haver liberdade de imprensa, ou seja não pode haver, nenhum tipo de sensura por parte do governo. Mas também relata o seguinte: os cidadãos não podem ter sua intimidade, vida privada e hora violada se acontecer deve ser remunerado por danos morais.

Para haver uma solução neste caso a imprensa e o governo devem entrar, em consenço, ou seja, deve ter uma união entre ambos ou os jornalista devem pagar quando fizerem uma reportage que viole os direitos dos cidadãos.

\footnotetext{
ANÁLISE

Macroestruturalmente, podemos dizer que o texto apresenta coerência, no entanto, muitas falhas internas podem ser encontradas.

A primeira delas refere-se ao primeiro parágrafo, em que percebemos a falta de unidade temática, sendo uma das condições de coerência textual. Isso acontece devido à confusão estabelecida pelo autor quando inicia dissertando sobre a profissão "jornalismo" para acabar mencionando "os meios de comunicação".
} 
Com relação à MR1, podemos perceber várias infrações. A primeira diz respeito ao uso excessivo de elipse, a fim de se referir ao termo "jornalistas" do primeiro parágrafo, o que pode acarretar dúvidas no leitor, devido à extensão do parágrafo:

O jornalismo é uma boa profissão para seguir, mas existem jornalistas que não respeitão as pessoas de baixa renda que vivem nas favelas ou em areas isoladas e de riscos, pois quando descobrem atravél de suas gentes ou pelo rádio da policia algum caso vão atrás não importando quem for, desrespeitando a constituição brasileira, mas não há como controlar o jornalismo pois também é contra a constituição, quer dizer contra a liberdade de imprensa, mas hoje há projetos para regularizar este impasse.

A escolha de vocábulos evidencia a falta de leitura e dificuldades do autor em se expressar de acordo com a norma culta. O uso do termo "de suas gentes" exemplifica o problema, além de não ser esclarecedor.

A repetição lexical (MR1) do termo "constituição", também no primeiro parágrafo, poderia ter sido efetuada com mais criatividade, devido à proximidade das palavras.

A falta de pontuação adequada prejudica o entendimento do leitor, como no segundo parágrafo, em que o emissor pergunta: “como pode-se considerar uma notícia de mal gosto ou ainda com a intenção de prejudicar alguém.". Não há ponto de interrogação.

Embora o grau de informatividade seja baixo, podemos dizer que há progressão entre os parágrafos. No entanto, várias lacunas são deixadas no texto, além da falta de concretude da conclusão.

\section{7-1}

\section{Comunicação absurda}

Pensamos que meios de comunicação como televisão e rádio é uma forma de nos manter informados de tudo, achando um máximo programas políciais. Acabamos assistindo por fata de opção, ficando simplesmente calados com o absurdo que olhamos.

Podemos chamar isso de abusos da comunicação, nos obrigamos a assistir programas como, "João Cleber", entrevistas extremamente sensacionalista, não se dando conta que podemos tirar idéias do que muitas vezes achamos absurdo. Muito menos se importando com 
crianças que assistem, sendo que elas guardam o que vêem e depois correndo grande risco de manifestarem o que viram na adolescência.

A garantia de informação cultural talvez não exista, se o telespectador continuar dando ibope para tanta ignorância. É melhor que em vez de olhar televisão ou escutar rádio, peguese um livro e leia, assim estamos enchendo nossos olhos e mente com cultura.

Concluindo, o abuso da comunicação só continuará se deixarmos esse sensacionalismo continuar tomando conta de nossas vidas. A conciência de informação e cultura tem que vir do povo.

\section{ANÁLISE}

Uma análise superficial do texto nos possibilita perceber a extensa dificuldade do autor em expressar suas ideias de maneira satisfatória. A oralidade e o coloquialismo estão presentes no texto, como em: "achando um máximo".

O recurso da MR1 foi utilizado de maneira indevida no segundo parágrafo, em que o demonstrativo não possui antecedente: "Podemos chamar isso de abusos da comunicação". Logo em seguida, encontramos uma sequência de infrações à MR4, tendo em vista a grande desarticulação entre as palavras. Um exemplo dessa infração é o momento em que o autor menciona: "entrevistas extremamente sensacionalista, não se dando conta que podemos tirar idéias do que muitas vezes achamos absurdo". O uso do pronome oblíquo "se", utilizado de maneira inadequada, acaba por confundir o leitor, já que este não sabe ao certo a pessoa gramatical à qual o pronome se refere.

O uso do termo "comunicação", no segundo parágrafo, é generalizante demais por abarcar uma quantidade muito grande de processos comunicativos, como a fala, a escrita e as linguagens não-verbais, quando o autor queria referir-se apenas aos meios de comunicação de massa como a televisão e o jornal. O caráter amplo da palavra esvazia o argumento, perdendo o seu poder de persuasão.

A partir do terceiro parágrafo, o autor procura propor sugestões para se resolver o problema dos abusos, no entanto, não sugere propostas concretas, mais uma vez culminando no senso comum.

\section{7-0}


Pelo fato de vivermos em um pais movido por preconceitos e assima de tudo, a falta de respeito e consideração que certos jornalistas tem com as pessoas. Invadindo a privacidade das mesmas e tornando mais difícil o trabalho de quem realmente tem de invadir as autoridades.

Durante séculos vemos na televisão, rádio e nos jornais a falta de consideração que a imprensa brasileira tem com o ser humano. Os jornalistas abusam da ignorância das pessoas e acabam manipulando e muitas vezes aumentando o que poderia ser um simples caso, por exemplo.

Muitas vezes, o trabalho de alguns políciais se torna mais difícil, os delegados que precisam de espaço para desvendar e resolver os casos mais tímidos pela nossa sociedade, acabam sendo atrapalhados pelo trabalho da impemssa. Os jornalistas querem de alguma maneira ter uma matéria importante, não lhes enteressa se tiverem que passar em cima de alguém, pois sempre irão alegar: "Esse é o meu trabalho".

Entretanto, a humanidade esta cansada de ser instrumento de matérias para o jornalismo, queremos assima de tudo privacidade e respeito. Assim poderemos viver em um ambiente mais saudável, e ter a segurança que nós e a nossa família não sofrerá, terendo que enfrentar as crueldades da mídia e dos jornalistas.

\section{ANÁLISE}

O texto nos surpreende logo no início, quando o autor infringe a MR1 e MR2 ao não dar continuidade à informação que principiou: "Pelo fato de vivermos em um pais movido por preconceitos e assima de tudo, a falta de respeito e consideração que certos jornalistas tem com as pessoas".

Mais uma vez, temos uma produção que não atingiu o objetivo demarcado pela proposta do ENEM. A questão da liberdade de informação não é citada em momento algum. Pressupõe-se, através do tema, que as informações que o emissor nos transmite referem-se aos abusos dos meios de comunicação, no entanto, ele não explicita esse fato.

No início do segundo parágrafo, nos deparamos com uma infração à MR3 no que diz respeito à contradição externa, pois a informação dada pelo autor contradiz o mundo real, haja vista a data real de criação, por exemplo, da televisão: "Durante séculos vemos na televisão, rádio e nos jornais a falta de consideração [...]”. 
Embora o texto não progrida em termos argumentativos, encontramos bons exemplos de articulação entre os parágrafos com o uso de locuções adverbiais e conjunção no início de cada um deles: "Durante séculos", "muitas vezes", "entretanto".

Outra infração à MR3 pode ter sido causada pela falta de uma revisão mais criteriosa do texto. Quando o autor menciona: “Assim poderemos viver em um ambiente mais saudável, e ter a segurança que nós e a nossa família não sofrerá, terendo que enfrentar as crueldades da mídia e dos jornalistas.", ele diz que não sofremos tendo que enfrentar as crueldades da mídia, o que é algo totalmente incoerente.

Em suma, não é um texto de difícil compreensão, mas que se limita bastante em termos argumentativos.

\section{0-4}

Os meios de comunicação trazem até nossos lares informações sobre o mundo. Sendo esses controlados por grandes empresários.

Muitas vezes passam por cima de culturas e privações não se importando com as consequiências, apenas procuram dar o melhor de si, para obter uma boa audiência, mostrando muitas vezes coisas não autorizadas pela pessoa o qual essa reportagem se refere.

Mas o que poucos sabem é que a imprensa não mostra somente a realidade, e também esconde fatos e relatos dos cidadões, para privar a imagem de outras pessoas, ela faz o que quer e mostra o que quer.

A imprensa invade a vida pessoal e profissional ela muitas vezes torna a imagem da pessoa motivo de ironia, ou até o torna um ídolo, tudo isso porque ela tem autonomia sobre os meios sociais e culturais.

A imprensa é um bem que as vezes se torna um mal, ela nos traz conforto, solidariedade, paz. Ela é o único meio o qual nos temos de sabermos o que está ocorrendo em todo o mundo; nos trazendo momentos de dor e alegria, nos possibilitando ter uma visão mais critica e objetiva sobre nós e o outro, sobre eu e você, sobre todos os seres vivos, os quais seu único objetivo é cada vez tornar-se melhor e construir um futuro de união e compreensão sobre o próximo sem discriminação étnico ou pessoal, sendo todos iguais e lutarmos pelo mesmo objetivo, a paz no mundo.

\section{ANÁLISE}


Esse é um texto que não apresenta tantos problemas em relação à decodificação. No entanto, muitas falhas podem ser verificadas, a começar pelo segundo parágrafo, em que o autor não nos deixa claro os referentes do verbo "passam", que podem ser tanto "meios de comunicação" quanto "empresários": "Os meios de comunicação trazem até nossos lares informações sobre o mundo. Sendo esses controlados por grandes empresários Muitas vezes passam por cima de culturas e privações [...]". Obviamente, se fizermos uma leitura atenta, percebemos que se trata dos meios de comunicação, no entanto, o antecedente mais próximo do verbo é "empresários", o que pode confundir o leitor.

Logo em seguida, nos deparamos com um termo empregado de forma inadequada, devido a informações contidas no parágrafo: “apenas procuram dar o melhor de si, para obter uma boa audiência, mostrando muitas vezes coisas não autorizadas pela pessoa o qual essa reportagem se refere.". A expressão "dar o melhor de si”" não cabe a essa situação, já que, em seguida, o emissor só atribui características negativas aos meios de comunicação.

A metarregra de repetição é utilizada de maneira satisfatória, com exceção apenas da palavra "imprensa", a qual foi reiterada diversas vezes (podendo ser de uma maneira mais criativa). Exemplos positivos podem ser encontrados no primeiro parágrafo, onde o autor faz uma substituição gramatical do termo "meios de comunicação" pelo pronome demonstrativo "esses”: “Os meios de comunicação trazem até nossos lares informações sobre o mundo. Sendo esses controlados por grandes empresários".

No terceiro e quarto parágrafos temos outra substituição gramatical. O autor reitera o substantivo "imprensa", utilizando o pronome pessoal "elas". No quinto parágrafo, encontramos o mesmo tipo de substituição, o que nos leva a crer que o campo semântico do termo, para o autor, é bastante restrito.

A infração mais grave, MR3, está no último parágrafo, onde o emissor menciona que a imprensa se torna um mal. Quando o leitor espera a explicação e exemplificação desse mal, depara-se com ações propriamente positivas, que contradizem totalmente a primeira afirmação:

A imprensa é um bem que as vezes se torna um mal, ela nos traz. conforto, solidariedade, paz. Ela é o único meio o qual nos temos de sabermos o que está ocorrendo em todo o mundo; nos trazendo momentos de dor e alegria, nos possibilitando ter uma visão mais critica e objetiva sobre nós e o outro, sobre eu e você, sobre todos os seres vivos, os quais seu único objetivo é cada vez tornar-se melhor e construir um futuro de união e compreensão sobre o próximo sem 
discriminação étnico ou pessoal, sendo todos iguais e lutarmos pelo mesmo objetivo, a paz no mundo.

Essa contradição é ainda mais evidente no momento em que diz que "o seu único objetivo é cada vez tornar-se melhor e construir um futuro de união e compreensão", pois o emissor acaba sendo contrário a tudo o que falou no decorrer de sua escritura.

\section{6-0}

É comum atualmente ligar-mos a televisão e assistir a cobertura dos programas jornalísticos sobre prisões, tragédias e todos os tipos de violência que ocorrem principalmente nas favelas. Porém os produtores destes programas nem sempre se preocupam com os direitos das pessoas, por isto deveria existir um controle mais rígido de fiscalização sobre as reportagens que irão ao ar e aos direitos dos cidadãos referentes à sua imagem.

Para o exercício da liberdade de imprensa ser exercido, basta a mídia entender que não precisa exagerar em suas reportagens, apresentando apenas o necessário para a compreensão do telespectador sobre a notícia apresentada, principalmente se ela envolver temas que mostre violência, pois de que adianta nos conhecê-lo a fundo se ela não nos ajudará em modo na vida.

Porém se for necessário, os sistemas de defesa das pessoas não devem hesitar em intervir, usando de uma certa rigidez que talvez fará com que pensem duas vezes antes de invadirem casas, com suas camêras e microfones movidos pelo impulso de chamar a atenção e respeitem um pouco mais a honra que certamente todo o ser humano tem.

E certamente, se a mídia entender que o seu ibope não está em mostrar a humilhação, vergonha e tristeza das pessoas, mas sim em uma matéria séria e sem abusos, com fins educativos e até mesmo de prevenir as pessoas aos perigos do dia-a-dia, aí então haverá uma harmonia entre a liberdade de expressão e informação, com os direitos dos cidadãos referentes à sua vida privada, sua honra e sua imagem.

\section{ANÁLISE}


Esse é um texto que não oferece dificuldades de decodificação. Podemos não concordar com algumas ideias do autor, mas facilmente sabemos o que ele quer dizer. Em um texto assim, é possível localizar o uso adequado dos requisitos de coerência.

A boa estruturação textual é resultado de boas ideias e partes do texto (MR4). Embora a introdução nos apresente o tema e de imediato proponha uma solução, no decorrer da dissertação, podemos perceber a retomada das ideias do parágrafo introdutório.

A progressão (MR2) encontra-se bem trabalhada, no segundo parágrafo, quando o autor retoma o assunto sobre a qualidade dos programas e acrescenta mais informações no sentido de criticar a mídia.

É importante dizer que faltou ao texto a inserção de mais elementos informativos referentes ao tema, tendo em vista que em todos os parágrafos, de alguma forma, o produtor propõe alternativas para a "resolução" do problema no que diz respeito aos abusos. No entanto, notamos que há um sequenciamento do pensamento.

A metarregra de repetição (MR1) é usada sem exagero, de modo a caracterizar a manutenção temática, embora encontremos algumas falhas no que se refere à norma padrão. Termos e expressões que fazem parte do desenvolvimento do assunto naturalmente se repetem, sem prejuízo ao texto. Em alguns momentos, o autor poderia ter sido um pouco mais criativo com relação à reiteração dos termos, como em: "Para o exercício da liberdade de imprensa ser exercido" e "apresentando apenas o necessário para a compreensão do telespectador sobre a notícia apresentada".

Vários exemplos de substituições gramaticais e elipses são encontrados, mas em apenas um a inadequação acontece devido ao desvio à norma: "[...] principalmente se ela envolver temas que mostre violência, pois de que adianta nos conhecê-lo a fundo se ela não nos ajudará em modo na vida.", pois o pronome oblíquo "lo" tem como antecedente a palavra "notícia".

Temos, pois, no que diz respeito à coerência, um texto praticamente inatacável. É evidente que não se trata de uma produção perfeita, mas revela um considerável poder de articulação lógica do pensamento.

\section{3-3}

Como garantir a liberdade de informação e evitar os abusos nos meios de comunicação? 
Nos dias atuais existem muitos abusos ao que se diz respeito a comunicação, filmagens sem permissão, imagens indecentes e muito capitalismo rodando a imprensa.

Ao que se diz respeito a garantia da liberdade de expressão está precária pois, as pessoas mais necessitadas, ao dar a sua opinião e reivindicar os seus direitos são deixados de lado em uma reportagem. São ouvidos e explanadas as idéias das classes mais altas e dos capitalistas, pois dentro disso e que esta a geração de lucro e emprego.

No tempo de eleições, milhares de casas de favelas, cortiços e outros são filmados sem autorização dos moradores, muitas vezes para serem usados nas campanhas, onde os candidatos culpam seus adversários por aquelas condições, e a imprensa sai ilesa pois o problema será visto no problema economico e não quem mostrou os problema, vai sobrar para os candidatos darem explicações sobre as condições precárias e não a verdadeira culpade de colocar aquilo à público.

A imprensa invade a casa das pessoas, mostrando até indecencias no horário comercial onde tem milhares de crianças assistindo e tirrando exemplos errados daquilo.

Sabemos que o mundo não existe sem informação mas, mesmo assim todos temos direitos de ser respeitados sem ter que assistir o que não querermos e nem de ter a sua imagem usada em uso de outras pessoas sem a sua autorização.

\section{ANÁLISE}

Percebemos, nesse texto, a extrema dificuldade do aluno em expressar suas ideias de maneira satisfatória. Não há uma introdução clara ao tema.

Nota-se que o conhecimento do assunto, por parte do autor, é bastante limitado. Uma primeira infração à MR3 pode ser notada logo no início do segundo parágrafo, tendo em vista que o emissor não tem conhecimento sobre o significado do termo "liberdade de expressão". Inicialmente, ele menciona os vários abusos dos meios de comunicação e logo em seguida nos diz que a liberdade de expressão está precária. Muitos leitores podem inferir a seguinte pergunta: "se não há liberdade de expressão, como pode haver tantos abusos?". Uma leitura mais atenta pode esclarecer o que o autor quis dizer, mas a escolha vocabular e a clareza do texto são de suma importância para persuadir o leitor.

A falta de articulação entre as ideias (MR4) pode ser notada em vários momentos, como no final do segundo parágrafo quando o autor nos informa sobre a "geração de empregos", que muito pouco se relaciona com o tema abordado. 
Com relação à MR1, podemos citar um exemplo do terceiro parágrafo, em que, além de apresentar falta de clareza, repete automaticamente vocábulos que poderiam ter sido mais bem trabalhados: "a imprensa sai ilesa pois o problema será visto no problema economico e não quem mostrou os problema”. Outro momento em que isso ocorre é em: "[...] nem de ter a sua imagem usada em uso de outras pessoas [...]”.

A limitação do autor em relação ao tema "meios de comunicação", atribuído apenas à televisão, dispõe-no a mencionar somente ideias do conhecimento geral, não contribuindo em termos informativos.

Assim, podemos inferir que falta ao autor conhecimento de mundo suficiente para que possa produzir um texto argumentativo de qualidade sobre o tema proposto.

\section{1-4}

\section{A corrupção de informações}

As informações que saem diariamente nas TVs, rádio, jornais, vem aumentando um porcentual muito elevado na forma de disrespeito.

Esse tipo de abuso vai aumenta ainda mais se ninguém se propor a enfrenta-lo. A imprensa vem encentivando as pessoas pelas telecomunicações a julgar os outros sem saber o que cometeram realmente. Para esse tipo de imprensa também devemos julga-los pelos seus invariaveis erros.

Eles tem o dever de entrevistar as pessoas mas com o respeito que todos merecem, e não tentar arrancar seus atos e depois expor para a mídia. Para os corruptos muitas vezes se nega a entrevista-los, porque o dinheiro compra a dignidade desses.

Devemos nos proteger mas também ser protegidos da imprensa pela policia que além de mais nada sua responsabilidade também e essa.

A informação devemos ter mas a que nos enteressa e não a vida intima da população.

\section{ANÁLISE}

Percebemos, nesse texto, uma grande dificuldade do autor em organizar suas ideias.

Mais uma vez, o parágrafo introdutório não nos deixa claro o tema. Além disso, falta clareza quando o autor menciona "desrespeito", pois não nos é informado "o desrespeito a quem ou a quê?" 
As metarregras MR1 e MR2 são infringidas várias vezes, como no segundo parágrafo, onde há repetição propriamente dita do vocábulo "imprensa" e diversas substituições gramaticais. No último período, o emissor cita o substantivo "imprensa" e utiliza o pronome oblíquo "los" para substituí-lo.

O mesmo ocorre quando o autor, no terceiro parágrafo, refere-se ao mesmo vocábulo, utilizando o pronome pessoal "Eles". A desarticulação também pode ser notada no terceiro parágrafo, quando é mencionado "Para os corruptos muitas vezes se nega a entrevista-los, porque o dinheiro compra a dignidade desses.". Além da informação não se relacionar com a anterior, o uso do demonstrativo "desses" torna bastante confuso o trecho, tornando-se difícil saber qual é o seu antecedente, tendo em vista as ideias que foram mencionadas.

No quarto parágrafo, a sequência de pensamentos também não se encontra muito clara. A princípio, parece-nos incoerente o enunciado: "Devemos nos proteger mas também ser protegidos da imprensa". No entanto, se fizermos uma leitura mais atenta, com algum esforço conseguimos entender o propósito do autor. Entretanto, se levarmos em conta que o interlocutor, muitas vezes, não consegue e nem pode intervir no momento da produção linguística (escrita) e nem solicitar explicações àquilo que está sendo dito, podemos dizer que a falta de clareza prejudica demasiadamente o texto.

O uso de vocábulos impensados também pode contribuir para o efeito contrário do que se esperava expor. Isso acontece no segundo parágrafo, quando o autor menciona: "Para esse tipo de imprensa também devemos julga-los pelos seus invariaveis erros.". Provavelmente, o objetivo teria sido dizer "vários erros" ou "erros variados", mas o emissor acabou por dizer o contrário ao utilizar o termo "invariáveis", pois se tem a impressão de que os erros são sempre os mesmos.

Além de todos os exemplos de falta de clareza, percebemos que não há estruturação do texto. Faltam ao autor conhecimentos mínimos da estrutura dissertativa, bem como conhecimento de mundo.

\section{7-8}

Com a grande quantidade de pessoas que tem acesso a algum tipo de meio de comunicação, ficou cada vez mais concorrida a disputa por algum tipo de reportagem...

A imprensa é livre para fazer o que quizer, muitas vezes abusando da própria.

O que primariamente foi a causa da morte da princesa Daiana em 1998 foi um exemplo do desrespeito da imprensa, ela estava num jantar com seu no namorado quando saiu 
do restaurante cercado de paparazzi, que a seguiram fazendo com que o carro onde ela estava se desgovernase e batese.

Existem leis para esse tipo de abuso, mas dificilmente são respeitados.

Vivemos num constante "Big brother" onde sempre estamos sendo vigiados, para que na primeira coisa que nos aconteça, nossa vida seje mostrada em revistas, jornais, televisão.

\begin{abstract}
ANÁLISE
Através da leitura do texto foi possível verificar, primeiramente, que o restrito conhecimento de mundo do autor interferiu de maneira marcante na elaboração do texto, visto que a dificuldade argumentativa associada à desarticulação das ideias culminou na produção de um texto desestruturado e baseado no senso comum.

O primeiro parágrafo não nos informa o tema do texto. O segundo parágrafo não tem relação nenhuma com o primeiro (MR2). O terceiro parágrafo é uma demonstração clara da infração à MR4 e MR2, tendo em vista que não há uma contextualização do assunto, o qual se encontra totalmente desconectado com o restante do texto.

Infrações à MR1 são encontradas em diversos momentos, como no quarto parágrafo em que o autor flexiona indevidamente o predicativo "respeitados", o qual, através da elipse, retoma "leis".

A conclusão não conclui, e muito menos propõe alternativas para a resolução do problema.

Em suma, o texto apresenta em toda sua extensão lacunas textuais. E sem o conhecimento de mundo suficiente, torna-se impossível para o aluno produzir um texto argumentativo de qualidade sobre o tema proposto.
\end{abstract}

\title{
0273402-8
}

\section{Como podemos garantir nossa liberdade de informarmos aos outros e evitarmos abusos nos meios de comunicação?}

Vemos todos dias nos programas de televisão, pessoas e câmeras invadindo casas para mostrar que vizinhos são acusados de roubos, o amigo morre, outro mata, será que a imprensa está agindo corretamente, é dever dela fiscalizar e mostrar o o que está acontecendo ou são os policiais que devem realizar este tipo de operação? 
Segundo o artigo $5^{\circ}$ da Constituição Federal de mil novecentos e oitenta e oito: X são invioláveis a intimidade, a vida privada, a honra e a imagem das pessoas, assegurando o direito a indenização pelo dano material ou moral decorrente de sua violação. Então se qualquer pessoa sofrer algum tipo de violação, como vem acontecendo ela tem o direito de recorrer a justiça pedindo idenização pela violação, seja ela de qualquer tipo.

Muitas pessoas acham que se forem até a justiça elas acham que vão ser prejudicadas, tudo isso acontece pela falta de informação, outras vezes porque as pessoas não se interessam por esse tipo de assunto e outras porque elas mesmas deixam os meios de comunicação anunciar.

\section{ANÁLISE}

É nítida, nesse texto, a falta de conectores entre as orações e parágrafos. Esse problema, associado à escassez de conhecimento sobre o tema abordado, acaba por prejudicar de maneira marcante o desenvolvimento do texto.

Temos, no primeiro parágrafo, informações sobre os tipos de notícias veiculadas na televisão, as quais o autor considera invasões da imprensa. Percebemos, nesse momento, ideias de abrangência muito vasta, comprometendo o esquema argumentativo exatamente por envolveram dados de realidade que têm em comum apenas alguns aspectos, tendo em vista que a generalização por parte do autor em atribuir à imprensa o papel de "invasora de casas" acaba por constituir uma afronta aos que estão relacionados a ela.

Outro fato que deve ser notado é que a estrutura esquemática não é seguida.

Deparamo-nos com um questionamento no final do primeiro parágrafo, o qual não é respondido, constituindo uma infração à MR2, já que não há continuidade e nem retomada do assunto.

No segundo parágrafo, o autor nos informa de uma lei que beneficia civis, no entanto, não articula essa ideia às outras partes do texto. Não há, nem mesmo, conclusão.

Em suma, a produção não atinge o objetivo esperado devido à falta de estruturação do texto e conhecimento de mundo do autor.

\section{2-5}

\section{A comunicação}


Todos os dias, somos informados de fatos ocorridos em todo o mundo. A imprensa é a responsável por coletar, organizar e transmitir para o povo, tudo o que acontece no país e no mundo. Revela furtos, golpes, a pobreza, mas também grande parte disso é manipulado pelos mais poderosos, acabando, muitas vezes, por transformar o ruim em bom e vice-versa. Mas como garantir liberdade de informação e evitar abusos na comunicação?

Dependemos da imprensa para nos interarmos dos acontecimentos mundiais. Somos alertados dos problemas que afetam nossa sociedade, incentivados, guiados pela comunicação. É através dela que é possível o relacionamento entre diferentes pessoas, rações, sendo indispensável para a vida conjunta.

Problemas como a precariedade da vida nas favelas, por exemplo, não seriam conhecidos se não fosse o trabalho da imprensa. Mas muitos dos fatos acabam encobertos devido ao poder de alguns de manipular e filtrar as informações que chegam até nós. Os poderosos preservam a imagem que eles possuem, portanto fazem com que chege até nós somente a imagem desejada.

Não há outra forma de associar a liberdade de informação e a verdade, se não dependendo da honestidade dos nossos jornalistas. Por isso acredito que o melhor que temos a fazer é não nos deixarmos levar por falsas impressões e analisarmos, no caso dos nossos políticos, o que eles realmente estão fazendo para melhorar o nosso país!

\section{ANÁLISE}

O texto não apresenta muitos problemas no que se refere à decodificação. No entanto, podemos encontrar várias falhas em seu desenvolvimento.

Verificamos exemplos bons e ruins no primeiro parágrafo, em se tratando da MR1. O uso de elipse, por exemplo, possibilita fluidez ao texto: "A imprensa é a responsável por coletar, organizar e transmitir para o povo, tudo o que acontece no país e no mundo. Revela furtos, golpes, a pobreza". Entretanto, em apenas três linhas o autor repete duas vezes o vocábulo "mundo", o que demonstra pouca criatividade.

Além disso, o uso do termo "comunicação" é generalizante demais por abarcar uma quantidade muito grande de processos comunicativos, sendo que o autor, possivelmente, tenha querido referir-se apenas aos meios comunicativos de massa.

No final do parágrafo introdutório, o autor insere uma questão (o tema), no entanto, não há progressão, pois ele não responde à pergunta, nem mesmo retoma o assunto sobre os abusos. Pelo contrário, o autor só parece mencionar coisas positivas sobre a "imprensa". 
A incoerência da conclusão é o que mais nos chama a atenção, pois a solução que o autor nos coloca é a de que fiquemos atentos às ações dos políticos, o que em nada se relaciona com o tema da proposta (MR4).

\title{
0273441-9
}

A imprensa precisa abusar de seu poder positivamente.

Atualmente, a imprensa é uma rica fonte de informação para todos os seres humanos. É importante salientar que ela está tendo uma vasta liberdade de expressão e que isso acaba ocasionando conflitos. Os órgãos comunicativos deveriam expôr notícias mais produtivas caso contrário, seriam punidos judicialmente.

Inubitavelmente o setor comunicativo teve sua liberdade ampliada desde os tempos da ditadura até os dias atuais. Porém essa conquista causando inúmeros equívocos. Isso porque as informações divulgadas são extremamente íntimas e, em certas ocasiões, pejorativas. Muitos cidadãos são afetados devido à exposição negativa da sua imagem.

É inegável a afirmação de que os programas sensacionalistas têm repercursão, entretanto se eles fossem substituídos por atrações culturais, trariam diversos benefícios ao público alvo. Esta nova programação relacionaria-se à artes, esportes, etnias, história... Enfim atividades que contribuíssem com o conhecimento. Para a concretização desse ideal a justiça deve punir à mídia, quando ela fazer divulgações pessoais e mesquinhas.

Tendo em vista o que foi mencionado percebe-se o quanto a mídia influi no pensamento das pessoas, e que infelizmente, de maneira geral, com aspectos prejudiciais. A justiça necessita fazer uso de seu poder para que a imprensa utilize a sua capacidade divulgativa com o intuito de expandir a sabedoria humana.

\begin{abstract}
ANÁLISE
Temos, aqui, um texto que, embora apresente várias falhas, é de fácil compreensão.

Podemos encontrar bons exemplos de articuladores (MR4), como no segundo e terceiro parágrafos, onde o autor utiliza advérbios e conjunções, a fim de conectar as orações, períodos e parágrafos: "Indubitavelmente", "porém”, "Isso porque”, "Entretanto” etc.

Exemplos de progressão também podem ser verificados, embora o grau de informatividade não seja tão elevado e, por vezes, falte clareza. Em: "Porém essa conquista",
\end{abstract}


retoma corretamente a ideia sobre o fim da ditadura do período anterior. A MR2 encontra-se bem trabalhada, pois o emissor cria claramente um sequenciamento do pensamento.

A metarregra de repetição (MR1) é usada sem exagero. Assim, termos e expressões que fazem parte da temática são substituídos por outros equivalentes, de modo a caracterizar a manutenção de mote. A exemplo, temos o termo "imprensa" o qual substitui lexicalmente e gramaticalmente no decorrer do texto termos como "órgãos comunicativos", "setor comunicativo", "mídia". O pronome "ela" e o uso de elipse garantem ao texto continuidade temática, sem repetição.

Temos, pois, um texto com boa estrutura e com ideias pertinentes, embora, em alguns momentos, falte ao autor dar continuidade ao que menciona, como no primeiro parágrafo quando diz: "Os órgãos comunicativos deveriam expôr notícias mais produtivas". O que seriam “notícias produtivas”? Não há explicação.

\section{6-0}

\section{Como garantir a liberdade de informação e evitar os abusos nos meios de comunicação?}

Os meios de comunicação são importantes para a nossa vida, pois através deles ficamos informados sobre tudo o que acontece no mundo, mas nós devemos assistir ou escutar aquilo que vale a pena, deixando de lado cenas de violência e coisas insignificantes.

Os jornalistas adoram uma "fofoca", quando acontece alguma coisa, eles são os primeiros a estarem no local dos acontecimentos sem pedir permissão. Essas pessoas devem respeitar mais o próximo, pois não são todos que gostam de expôr sua vida pessoal.

Os mais prejudicados com isso são os famosos, tudo o que acontece com eles a mídia já está filmando. É claro, que nós gostamos de ficar sabendo mais sobre nossos ídolos, mas se fosse com nós, será que iríamos gostar?

Essa é uma questão que deve ser analisada, nós devemos respeitar a intimidade dos outros, para que eles também nos respeitem. Cada um deve cuidar da sua vida, não se metendo na vida dos outros.

Os jornalistas devem ter um limite e nos passar apenas informações interessantes. É necessário o nosso país tomar algumas atitudes, não permitindo esses abusos que influencia as pessoas, principalmente as crianças que crescem vendo essas cenas de violência que aumentam a cada dia. 
A maioria das pessoas gostam de ter a sua imagem preservada, sem ser exposta em jornais, revistas, esse é um direito nosso que deve ser respeitado.

Somos seres humanos e temos a liberdade de viver em paz, longe das câmeras e da mídia, que usam as informações sobre nossa vida para vender cada vez mais.

\begin{abstract}
ANÁLISE
Embora o texto seja de fácil compreensão, suas informações são bastante previsíveis, não acrescentando muito em termos informativos.

A limitação conceitual de "meios de comunicação" à televisão é aparente. O coloquialismo também pode ser verificado na produção, constituindo um desacerto no que se refere ao poder de persuasão do autor. Termos como "fofoca", "se fosse com nós", "não se metendo na vida dos outros", entre outros, acabam por tirar a credibilidade do texto.

Encontramos adequações no que se refere ao requisito da MR1. No segundo parágrafo, por exemplo, o termo "jornalistas" é substituído gramaticalmente pelo pronome "eles” e, em seguida, pelo demonstrativo acrescido do substantivo: "Essas pessoas".

Podemos dizer que há certa progressão no terceiro parágrafo, pois o autor retoma, através do pronome "isso", a ideia do parágrafo anterior e acrescenta novas informações.

Apesar de o emissor relatar sobre alguns abusos dos meios de comunicação, não o faz com propriedade. Além disso, temos um texto que apenas expõe fatos e não alternativas para que os abusos referidos finalizem.
\end{abstract}

\title{
0273471-0
}

Como garantir a liberdade de informação e evitar os abusos nos meios de comunicação?

Nós seres humanos, devemos nos respeitar uns aos outros para que não hajam conflitos. Não devemos colocar uma matéria em um jornal sem que seja autorizado pela vítima para não causar vexame, nem sair falando em programas de rádio da vida alheia sem saber da verdade, pois isso muitas vezes deixa as pessoas constrangidas, até com vergonha de sair na rua por ter ouvido seu nome ser pronunciado criticamente em um programa de rádio, sem mesmo ele saber do que se tratava o assunto. 
Pessoas ficam imaginando coisas na sua mente e acabam achando que isso é verdade e passam para frente a idéia expondo para várias pessoas até tornar em confusão e até mesmo morte e prisão de pessoas inocentes.

Porém, quem faz esse tipo de coisas deve por o dedo na consciência e ter noção de seus atos, pensar antes de agir e só falar quando realmente saber de toda a verdade, por mais dura que seja, ai ela pode ser dita sem medo.

\begin{abstract}
ANÁLISE
Mais uma vez, pode-se verificar que o restrito conhecimento de mundo do autor interferiu de maneira marcante na elaboração do texto. Redundâncias, oralidade e emprego de noções confusas permeiam toda a produção.

Não há uma introdução clara ao tema e $\operatorname{logo}$ no primeiro parágrafo encontramos muitos exemplos de escolha vocabular inadequada. Em "para que não hajam conflitos", não sabemos que tipos de conflitos poderiam ser causados, pois não há explicação.

O termo "vítima" também ocasiona dúvidas ao leitor, já que nem todas as matérias publicadas em um jornal possuem "vítimas". Em seguida, encontramos a expressão "causar vexame", a qual causa incredibilidade ao texto, por apresentar um caráter vago e fazer parte de uma linguagem do dia-a-dia.

Outro exemplo de vocábulo com caráter amplo e vago está em: "Pessoas ficam imaginando coisas na sua mente [...]". A palavra "coisa" precisaria ter sido definida para depois ser explorada, pois sem o seu real significado, o argumento se esvazia, afastando ainda mais o leitor.

Embora o texto não apresente dificuldades em relação à compreensão, seus argumentos e ideias são muito vagos, culminando no senso comum. A conclusão se estrutura em ideias sem fundamento (“deve por o dedo na consciência”) e em escassez de propostas concretas.

Não há articulação, nem mesmo progressão no texto devido à falta de leitura do produtor e desfamiliarização com a escrita.
\end{abstract}

\title{
0273475-3
}

\section{Respeito mútuo}


Depois de um dia cansativo de trabalho, de uma manhã de aula, ou até ao retornarmos de um passeio, temos o costume de sentar no confortável sofá da sala para relaxar, e ligar a televisão para nos distrairmos um pouco. Nos deparamos, às vezes, com o drama de uma família sendo mostrado no noticiário, ou até com a privacidade de um famoso num programa de fofocas o que nos chama a atenção e nos faz ficarmos grudados na "telinha" até o final da reportagem.

Em momentos como esse, ficamos curiosos quanto a vida das pessoas em uma favela no Rio de Janeiro, ou em relação às "intimidades” de uma atriz famosa e nos deleitamos com programas que satisfaçam essa nossa curiosidade, mas nunca paramos para pensar se estas pessoas, expostas tão vulgarmente pela mídia, estão se sentindo bem. A imprensa costuma passar por cima de qualquer moral para superar a audiência de seus rivais e, enquanto relaxamos com nossa família, muitas pessoas são atormentadas dia e noite por jornalistas e fotógrafos.

Existem momentos, às vezes trágicos ou dolorosos, em que as pessoas precisam de privacidade, e não da imprensa querendo reportar o acontecimento. Porém, nada impede que a mídia exponha os fatos, apenas precisa saber como fazê-lo. Não podemos julgar tão somente os meios de comunicação, porque estes precisam passar para o público o que vêm a ser notícia.

A informação sobre o que acontece em nosso meio é indispensável, e assim como há leis para uma empresa de comunicação, existem direitos para os cidadãos que devem ser respeitados. Jornalistas e fotógrafos deveriam agir com mais discrição e respeito à individualidade de cada um, compreendendo que existem momentos para cada coisa e maneiras diferentes de expor o assunto, evitando, assim, o constrangimento de várias pessoas. É possível e necessário um respeito mútuo entre o cidadão e imprensa.

\section{ANÁLISE}

Esse texto apresenta boas qualidades no que diz respeito às regras de coerência, embora contenha falhas mais ou menos graves.

A progressão pode ser notada entre o primeiro e segundo parágrafos. Na passagem: "Em momentos como esse, ficamos curiosos quanto a vida das pessoas", observamos a retomada ao primeiro parágrafo, em que o autor insere uma sequência de momentos do dia-adia; posteriormente, nos dá exemplos de "atrações" as quais costumamos assistir na televisão, garantindo, dessa forma, informações novas ao texto (MR2). 
O recurso da MR1 também parece estar bem trabalhado no texto. Termos como "os meios de comunicação", "mídia”, "imprensa de comunicação", entre outros pronomes substituem o substantivo "imprensa”. Além disso, este não é reiterado com exagero.

No que diz respeito à estrutura, embora tenhamos um fechamento da discussão, falta à conclusão sugestões concretas para a resolução do problema em questão. Além disso, em nenhum momento o autor disserta sobre a questão da liberdade de expressão.

Em suma, embora o texto apresente boa articulação, o autor peca em termos conteudísticos por não abordar o tema de forma integral.

\section{0-0}

\section{Mídia e Lazer: Nem tudo a ver...}

Hoje em dia, o que se vê na mídia é algo lamentável. Pessoas expõe sua privacidade em troca de fama e fortuna instantâneas; crimes hediondos ou não, são discutidos não para que se tomem atitudes, mas para alavancar a audiência de programas sensacionalistas. Sem contar com a pornografia, presente em todos os meios de comunicação de massa, onde pessoas de todas as idades podem acessá-la sem impecílios.

Quem busca informação ou somente diversão, depara-se com uma verdadeira avalanche de baixarias, mentiras, escândalos, e coisas que são totalmente desnecessárias para quem quer se distrair.

O pior é que pessoas, principalmente de baixa renda, que não tiveram acesso a uma educação melhor, são facilmente influenciáveis, e acabam por acreditar em toda bobagem que ouvem ou vêm por aí, acabando por ter uma visão distorcida dos fatos.

A principal maneira de elevar o nível da mídia em geral é que os profissionais responsáveis pela divulgação dos fatos tenham bom senso e ética na hora de escolherem o que vai ser apresentado para o público, levando em conta o fato de crianças serem mais influenciáveis que os adultos; sendo assim, devem evitar que a imoralidade se propague.

É preciso também que a veracidade dos fatos seja buscada, a privacidade de todos seja poupada, e que discussões sejam feitas para que todos tomem consciência dos problemas graves que a sociedade enfenta.

Se isso não puder ser feito, quem está assistindo ou ouvindo deve pensar no que está sendo dito e mostrado, pois só ele pode formar sua opinião quando aos fatos. E é só ele que tem o poder de dizer o que ele acha certo ou não. 
Na dúvida, não ligue seu rádio hoje; não assista TV por uma semana, deixe a Internet de lado por uns dias e nem passe perto de jornais e revistas, á procurar a companhia de quem você gosta, faça passeios ou visite um museu, ou simplesmente olhe para o céu e veja a beleza das nuvens, você nem sabe o bem que está fazendo a si mesmo.

\begin{abstract}
ANÁLISE
Estamos diante de um texto que apresenta bastante facilidade de compreensão, apesar de, por vezes, pecar no que se refere ao conteúdo. Os desvios à norma não são muito significativos e a sequência de pensamento é adequada.

No primeiro parágrafo, o autor discute sobre os abusos cometidos pelos meios de comunicação, com vários exemplos, embora limitados à televisão. Uma generalização acaba por provocar no leitor dúvida em relação à crença ao texto. Isso ocorre quando o emissor menciona: "Sem contar com a pornografia, presente em todos os meios de comunicação de massa", em que além de fazer uso de um termo genérico, utiliza noções semiformalizadas, já que não define quais seriam esses meios de comunicação.

Um problema relacionado à acentuação do texto pode ser verificado pelo leitor em todo o segundo parágrafo, pois nele o autor nos dá a entender que os meios de comunicação somente transmitem fatos, ideias e informações negativas, o que não é verdade, devido à gama de assuntos que exibem.

Do primeiro ao terceiro parágrafos, não encontramos o requisito da articulação. Ideias estanques são transmitidas, sem a preocupação com a conexão dos pensamentos.

A partir do momento em que o autor começa a dissertar sobre como a mídia deveria agir, a articulação entre os parágrafos surge (MR4). A progressão pode ser notada através de termos como "É preciso também" e "Se isso não puder ser feito".

No entanto, a conclusão deixa a desejar. O autor se dirige diretamente ao leitor com extrema intimidade. Além disso, propõe atitudes "paliativas" em relação ao problema do abuso, que não resolvem nem respondem à pergunta do tema.
\end{abstract}

\title{
0273510-5
}

\section{Informação, na medida certa}


Uma questão de respeito, e direito. Não estamos livres da mídia. Se pararmos para pensar, estamos sendo observados, em qualquer lugar, nínguem está livre das malditas câmeras. Que muitas vezes são necessárias, e muitas desnecessárias. Só é uma questão de entendimento, onde jornalistas e pessoas públicas tendem a chegar numa conclusão. Onde começa o direito de um, acaba o do outro.

A mídia precisa conscientizar-se, que nem tudo que é visto, deve ser publicado para todos. É uma questão de privacidade, de que todos precizamos. A medida que se invade a privacidade de alguém, está sujeito a pagar pelo que fez. As vezes na justiça, outras infelismente não.

As pessoas públicas precisam se conscientizar de que vivem num país livre, onde as pessoas têm necessidade de saber o que aconteçe, e com quem aconteçe, pois os seres humanos precizam de informação. Mas o limite acaba aí. Os seres humanos não precizam de fofocas, nem de baixaria. É aí que entra o respeito e a privacidade. Quem são os maiores prejudicados, com tudo isso, são os famosos, as celebridades, que estão na mídia, e precizam dela.

Sé é difícil concientizar todos, o certo seria estingir de uma só vez os jornalistas, que não cumprem seu papel honestamente, e as pessoas ignorantes, quem sabe assim haveria mais entendimento entre as pessoas.

\section{ANÁLISE}

Embora o título do texto chame bastante atenção, ao nos depararmos com o primeiro período, ficamos surpreendidos pela total falta de nexo da proposta: "estingir de uma só vez. os jornalistas, que não cumprem seu papel honestamente".

Não há situacionalidade, nem articulação entre os períodos iniciais. Poderia até fazer algum sentido se esse primeiro período fosse uma extensão do título, mas não há como saber qual foi o real objetivo do emissor.

O texto apresenta diversas falhas no que diz respeito à coerência e também à aceitabilidade. Quando, no primeiro parágrafo, o autor menciona que "não estamos livres da mídia" acaba por carregar esse trecho de um valor negativo, deixando mais ou menos claro, para o leitor, o seu posicionamento radical sobre o assunto. Em seguida, o adjetivo "malditas" contribui ainda mais para transmitir esse pensamento.

O segundo e o terceiro parágrafos chamam a atenção, pois se o leitor não fizer uma leitura atenta, poderá entender que os dois parágrafos se contradizem. O segundo fala da 
questão da privacidade que não deve ser invadida; e o terceiro fala sobre a liberdade de informação a que todos têm direito. Por fim, o autor finaliza dizendo: "Mas o limite acaba aî", o que acaba por confundir ainda mais o leitor já que "se o limite acaba", tudo pode acontecer (MR3).

A conclusão do texto é o momento em que o autor perde mais fortemente seu poder argumentativo, pois sua proposta é de "estingir de uma só vez os jornalistas, que não cumprem seu papel honestamente". Em primeiro lugar, a proposta contradiz o mundo real, já que é uma atitude pouco provável de ser tomada. Em segundo, mais uma vez, os conceitos e afirmações genéricas do autor prejudicam seu texto, principalmente quando menciona que "os jornalistas não cumprem seu papel honestamente," decaindo, novamente, na questão da aceitabilidade. Outra ideia absurda do produtor seria em relação à extinção de pessoas ignorantes, proposta que nem merece comentários.

\section{7-2}

\section{Liberdade de informação sem abusos.}

Nos dias atuais, vivemos em um mundo de muita informação. Além disso temos a liberdade de informação, mas muitas vezes temos que evitar abusos nos meios de comunicação pelo qual somos informados.

Um método para garantir a liberdade de informação é tentar informar-se da melhor maneira possível sobre o assunto. Além disso, deve-se buscar uma liberdade a partir dos fatos que a informação apresenta.

Outro método é evitar que ocorram abusos nos meios de comunicação. Muitas vezes, quande se assiste um tele-jornal ouve-se várias notícias, algumas até são interessantes, mas a maioria abusivas. Para garantir a liberdade sem abusos é fazer matérias bem mais informativas.

Assim sendo, percebo que o ser humano deve ficar bem-informado com liberdade de informação. Mas, com isso deve-se garantir a liberdade de informação evitando abusos nos meios de comunicação.

\section{ANÁLISE}

Verifica-se, primeiramente, que o restrito conhecimento de mundo do autor interferiu de forma marcante na produção do texto, que não tem cognição nem mesmo sobre o tema, já 
que o autor não consegue desenvolver o assunto e menciona ideias confusas sobre a questão da liberdade de informação.

A repetição das mesmas ideias, que por sua vez pouco informam, é aparente durante todo o texto.

O recurso da MR1 não é utilizado de maneira satisfatória, tendo em vista que o emissor repete diversas vezes os vocábulos que fazem parte da temática. A exemplo, temos o substantivo "informação" e suas variações que é repetido de modo automático dez vezes em todo o texto, que não é longo. O mesmo ocorre com o vocábulo "abusos", o qual se repete cinco vezes.

Não há progressão (MR2), pois em todos os parágrafos o autor "tenta" nos dizer a mesma informação.

O texto apresenta em toda sua extensão lacunas textuais, que mesmo complementadas pela ação interpretativa do leitor, dificultam o entendimento da produção. Isso ocorre, por exemplo, quando o autor menciona: "Um método para garantir a liberdade de informação é tentar informar-se da melhor maneira possível sobre o assunto."; e também em: "deve-se buscar uma liberdade a partir dos fatos que a informação apresenta.". Não se tem a mínima clareza sobre o que o emissor quis transmitir.

A desarticulação entre os períodos e parágrafos é total (MR4).

Uma infração à MR3 pode ser claramente verificada entre o segundo e o terceiro parágrafos. O segundo tem início com a seguinte informação: "um método para garantir a liberdade de informação é [...]", e o terceiro inicia dizendo que: "outro método é evitar que ocorram abusos nos meios de comunicação". O autor contradiz justamente o questionamento proposto no tema, pois coloca que uma maneira de garantir a liberdade de informação é evitando os abusos dos meios de comunicação.

Em suma, temos um texto em que todas as metarregras são infringidas. Tem-se a impressão de que o autor não tem a mínima ideia do que esteja falando.

\section{6-1}

\section{O Abuso da Publicidade}

Para virar notícia ou estar na boca do povo, hoje em dia não é preciso muito esforço, principalmente se você ja for popular ou sem influído. A empresa não respeita mais a intimidade de quem quer se seja, não liga se é um caso famíliar, particular; O que importa pra 
eles e ser o primeiro a levar tudo a tona, a fazer com que todo mundo fique sabendo ou simplesmente fazer fofoca.

O que é muito errado - você tem direito a sua privacidade isto é lei, não é questão de ser chata, ou não querer se fotografado, aparecer na mídia, é a sua vida você faz dela o que você bem entender, sem dar satisfação pra ninguém, isso é o que eles também devem achar, que tudo pode ser mostrado, exibido, sem a sua autorização.

Se é a sua vida ou os seus problemas, ninguém tem o direito de invadi-la, nem que seja pra justificar um salário no final do mês.

\section{ANÁLISE}

O texto nos surpreende antes mesmo de ser totalmente lido. Uma infração à MR4 pode ser notada logo no título, tendo em vista que este não tem relação alguma com o desenvolvimento do texto.

Embora a "publicidade" (o texto publicitário) seja um meio de comunicação que tem por objetivo persuadir o leitor, não há no texto informações remissivas ao título, ficando este totalmente desconexo.

Outro defeito argumentativo pode ser verificado em referência ao coloquialismo utilizado pelo autor. Termos e frases prontas como "estar na boca do povo", "não liga se [...]", "levar tudo a tona", "fofoca", "ser chata"; empobrecem ainda mais o texto no que diz respeito à persuasão.

A falta de revisão e os desvios à norma tornaram o texto incoerente devido à escrita inadequada; muitos exemplos desse tipo são verificados, como em "[...] se você já for popular ou sem influído" e em "A empresa não respeita mais [...]”. Levando em consideração o contexto, podemos inferir que "influído" seja "ter influência; e "empresa" signifique "imprensa", mas na escrita, como se sabe, tudo deve ser dito com muita clareza, para que o leitor possa compreender o objetivo do autor.

Outra infração à MR3 pode ser notada no segundo parágrafo: “O que é muito errado você tem direito a sua privacidade isto é lei, não é questão de ser chata, ou não querer se fotografado". O uso do hífen pressupõe uma explicação do que foi dito, culminando numa incoerência já que não é errado termos direito à privacidade. Talvez esse trecho (anterior ao hífen) fizesse parte do parágrafo que o antecede, mas não há como saber.

Em suma, o texto apresenta várias lacunas que, muitas vezes, o leitor não consegue completar. Há pouco conhecimento sobre o assunto "abordado" e fuga parcial ao tema. 
0273539-3

\section{Meios de Comunicação}

Abusos nos meios de comunicação, são feitos com intenidade, por parte dos jornalistas e de sinegrafista que trazem as notícias do dia.

Cada acontecimento que há nas cidades ou em estados vizinhos, vários cinegrafistas envadem os locais, fazendo com que as pessoas envolvidas se revoltem contra eles. Isto se deve, por causa da invasão da privacidade.

Há também, jornalistas que fazem aumentos absurdos sobre os casos, somente para dar audiência em seus programas, fazendo com que a população que está assistindo, ache que tudo é verdade.

Deveria, existir mais cuidado, por parte das pessoas que comanda os meios de comunicação, não invadindo a privassidade de pessoas envolvidas nos casos, fazer com que a notícia que iram passar aos telespectadores, chegue de forma clara, sem nenhum tipo de modificação.

Para garantir a liberdade de informação, é preciso que pessoas ligadas aos meios de comunicação passe a observar casos, sem filmar, assim não irá invadir a privacidade dos envolvidos.

Caso as pessoas que estão envolvidas permitirem, ai sim jornalista poderam gravar, fazer anotações, para depois passar aos telespectadores.

Só assim, poderemos garantir a liberdade de informação, sem acontecer abusos por parte dos jornalistas.

\section{ANÁLISE}

Ao ler esse texto é possível verificar a desfamiliarização do autor com a escrita. Os desvios em nível formal, especialmente no tocante à ortografia, acentuação e pontuação são graves. Além da desestruturação formal, percebemos que não há muita contribuição no que se refere ao conteúdo informativo.

Outro fato que deve ser destacado é que o autor atribui os abusos dos meios de comunicação somente e exclusivamente aos jornalistas, ocasionando possíveis problemas com relação à aceitabilidade do texto pelo leitor.

Infrações à MR1 podem ser notadas durante todo o texto devido à repetição automática de vocábulos. A palavra "invasão" e seus derivados, por exemplo, é repetida 
quatro vezes em parágrafos que também repetem as mesmas ideias. O mesmo ocorre com o vocábulo "envolvidas".

Não há progressão entre os parágrafos, nem mesmo conexão (MR2-MR4). Palavras que possuem caráter amplo são usadas diversas vezes, sem que haja explicação por parte do autor. No trecho "[...] jornalistas que fazem aumentos absurdos [...]" o produtor não esclarece o tipo de aumento a que se refere ou sobre o que os jornalistas aumentam.

Em suma, o autor repete as mesmas ideias em praticamente todo o texto e apesar de tentar propor uma alternativa para o problema, não o faz com propriedade. Pela leitura, podemos inferir que não há conhecimento de mundo suficiente para o aluno produzir um texto argumentativo de qualidade sobre o tema proposto.

\section{7-4}

\section{A imprensa.}

Em fim, a violência no Brasil está se tornando mais difícil, por isso, nós que vivemos no meio desta opinião citada acima, devemos nos conscientizar que não podemos fazer com que esse fato não aconteça mais, portanto, nós brasileiros, devemos parar, pensar pelo o menos uma vez em, violência no trânsito casos de estupro. Nesse fato mensionado só nos leva ao nível mais baixo do que nos temos hoje.

Portanto, para que isso não ocorra, nós brasileiros devemos ter mais orgulho pelo nosso país, pois, não é tão difícil é só nós pegarmos os pontos e resolve-los de uma vez por toda, porque nós sejamos um pais de primero mundo é claro se nós fizermos junto com a imprensa. Entretanto o que já citado nessa redação e reveria com que nós pensarmos mais antes de fazer as coisas porque isso acabasse de uma vez por todas. Enfim, quem não gostaria de um Brasil lindo e em $\left(1^{\circ}\right)$ primeiro lugar.

\section{ANÁLISE}

O texto surpreende antes mesmo de ser totalmente lido, por iniciar com um advérbio que indica finalidade: "Em fim" (enfim).

A falta de capacidade do autor em expor suas ideias de maneira satisfatória é extrema. A dificuldade argumentativa associada à desorganização de pensamentos culminou na 
construção de parágrafos, períodos e orações desconexos que expõem ideias contraditórias, corroborando a falta de coesão e coerência do texto.

Uma leitura global revela uma quase total desarticulação entre o texto e o tema proposto no título: "Imprensa". Apenas no antepenúltimo período do texto é mencionado o vocábulo, mas sem que haja articulação direta com as outras "informações" da produção. A desarticulação entre título e conteúdo configura uma espécie de infração à metarregra de relação (MR4). Aliás, essa infração pode ser notada diretamente em todo o texto, já que este não aborda o assunto requerido no tema.

Mesmo não levando em consideração o eixo temático, as incoerências do texto são diversas. A produção começa com a seguinte informação: "nós que vivemos no meio desta opinião citada acima", que logo faz surgir a pergunta pelo antecedente: qual opinião?

O texto apresenta em toda a sua extensão lacunas difíceis de serem preenchidas pelo leitor. Em: "nós brasileiros, devemos parar, pensar pelo o menos uma vez em, violência no trânsito casos de estupro.", o obscurantismo permanece, pois não se sabe o que o autor quis transmitir com tais ideias. No segundo parágrafo o autor menciona: "é só nós pegarmos os pontos", mas que pontos seriam esses?

No último período, o autor finaliza dizendo: "Enfim, quem não gostaria de um Brasil lindo e em $\left(1^{o}\right)$ primeiro lugar.", no entanto, ele não explica o sentido de primeiro lugar.

Enfim, revelam-se, nessa redação, muitos problemas com relação ao domínio de habilidades de leitura e escrita por parte do autor, além do pouco domínio da estrutura do texto escrito.

\section{5-5}

\section{Tempos Modernos: Privacidade ou Liberdade a Imprensa?}

Antigamente o homo sapiens não tinha conhecimento do que acontecia no mundo, sabia-se apenas a notícia dos arredores, mas com o passar dos anos e graças aos estudiosos a tecnologia foi se transformando e agora contamos com a maior fonte de informação.

Para se chegar a tecnologia da informação, que temos hoje, levou-se muitos anos e também foi preciso muito estudo, muita dedicação, muita criatividade e principalmente a ciência.

O direito a privacidade é assegurado em lei, mas nem todos obedecem-na e abusam da ingenuidade dos pobres para fazerem seus programas. 
Só não fica plugado no mundo quem não quer pois as informações são transmitidas através de vários meios de comunicação, tais como: televisão, rádio, jornais, revistas, internet, etc.

Portanto todos devem excercer sua cidadania, os jornalistas com educação e respeito pois só assim teremos uma era de informações dentro da lei.

\section{ANÁLISE}

O primeiro fato que deve ser destacado é que o autor da redação não desenvolve adequadamente o título que propõe.

Uma primeira infração à MR2 ocorre no início do texto, no primeiro parágrafo, onde o autor nos diz que "agora contamos com a maior fonte de informação", no entanto, não esclarece ao leitor qual é essa fonte. O segundo parágrafo é basicamente uma repetição do primeiro. Não há progressão.

O único momento em que o produtor cita a questão da privacidade (colocada no título) é no terceiro parágrafo, mas pouco fala sobre o assunto. No mesmo parágrafo, outra lacuna é deixada pelo autor, quando menciona: "mas nem todos obedecem-na e abusam da ingenuidade dos pobres para fazerem seus programas.". É citado sobre a ingenuidade dos pobres, no entanto, essa informação acaba por cair no obscurantismo, pois não há explicação do fato e nem contextualização da informação.

Não há conexão alguma entre as ideias do texto, ficando evidente a falta de conhecimento de mundo do autor sobre o assunto.

\section{4-4}

\section{Visões Interpretadas}

A mídia sensacionalista expõe cada cidadão de forma a forçá-la a aceitar informações prontas, construidas com base no diálogo nacional e mundial, formas de expressão e relatos pessoais.

O diálogo inserido com noticiários e jornais, coloca cada vez mais, em primeiro lugar, pessoas de alto nível sócio-econômico, fazendo a se entender, serem a base da lingua nacional. 
O único sentido do "tentar se expressar" é consegui-lo, pois a cada passo que a palavra anda em torno do mundo do entendimento, se propõe a melhorar, fazer cada vez mais a formas de linguagem abrirem espaço para percepção instantanea, ou seja, fazé-la sem vê-la.

A relação de convivência de palavras e atos é que cada um tem seu modo particular de se apresentar, no geral, onde pessoas disem ser donos da mídia, fazer as cenas acontecerem, desde que não torne difícil o entendimento a cada um de nós, os quais essas pessoas tem que satisfazer no todo observada.

A mídia coloca em nossos lares todos os dias, as notícias prontas, que não precisam pensar, é só digerir, mas cobram o insentivo para seu contínuo aperfeiçoamento dessas técnicas, os quais, nós aceitamos e nos colocamos a disposição de vos servi-los.

\section{ANÁLISE}

Podemos perceber, nesse texto, a extrema dificuldade do autor em articular suas ideias de maneira satisfatória.

O texto apresenta em toda sua extensão lacunas textuais, que mesmo completadas pela ação interpretativa do leitor, dificultam o entendimento do texto.

Não há uma introdução clara ao tema. Infrações à MR4 podem ser encontradas a todo momento, pois não há relação entre os parágrafos.

Uma leitura global revela uma quase total desarticulação entre o texto e o tema proposto, configurando mais uma vez uma infração à MR4.

É extrema a dificuldade do produtor em utilizar aceitavelmente e compreensivelmente a modalidade escrita da língua portuguesa. Além da desestruturação formal, há muitos problemas no aspecto lógico-semântico, como exemplo disso temos: “O diálogo inserido com noticiários e jornais, coloca cada vez mais, em primeiro lugar, pessoas de alto nível sócioeconômico, fazendo a se entender, serem a base da lingua nacional.", em que não se sabe o que o autor quis dizer. Exemplos desse tipo podem ser encontrados em todo o texto.

Assim, verificamos que o restrito conhecimento de mundo do aluno, somado à desfamiliarização com a escrita, tiveram por consequência um texto demasiado confuso que não atinge o objetivo da proposta do ENEM.

\section{6-5}

\section{Liberdade sem Abuso}


A comunicação é de muita importancia para a população mundial, pois é apartir da informação que ela nos passa, que saberemos o que esta certo ou errado, o que esta sendo feito ou o que está sendo deseado de fazer por nós e além de ser para alguns um momento de laser como é o caso da TV que é uma cultura.

Para se obter uma boa e precisa informação precisamos que a mídia tenha uma certa liberdade para nos expor, mas somente o que irá ser de importância para nós, "o povo", que precisamos estar cientes do que esta acontecendo no mundo, pois se tudo ficar as escuras, se eles abafar tirar o que é nosso e tomos o direito de exigir, e é por isso que a sensura nesse ponto de vista não deve acontecer, devemos nos manter informados, para crescer na vida, para poder trancar o pé se tem algo de errado para termos o que argumentos e é para isso que tempos a comunicação que não são poucas temos a TV que além de nos passar informação é um lares, o formal, radio, revista o agora mais recente a internet.

O meio de comunicação deverá passar para sua "clientela" o maximo de informações úteis, mas sem entrar na vida intima, sem prender as pessoas com comentários inúteis, que serve para alimentar cada vez mais a fofoca em todo nós.

Portanto, para se botar limites entre a liberdade de informação e o abuso de comunicação devemos exigir parametro que faça das obras uma só e gravitando delas só o pessoa, digo, necessário para nosa vida.

ANÁLISE

Embora o texto não apresente tantas dificuldades em relação à decodificação e siga o assunto pedido, o grau de informatividade é bastante baixo.

O segundo parágrafo peca por apresentar noções de totalidade inadequadas quando menciona: "mas somente o que irá ser de importância para nós, 'o povo"'. No entanto, no momento em que o autor afirma que somente informações importantes para o povo devem ser transmitidas, ele não leva em consideração a subjetividade, pois o que é importante para um pode não ser para o outro. Esse argumento torna-se, assim, vago. Além disso, todo esse parágrafo é comprometido devido à falta de conectores, que acabam por tornar o texto confuso (MR4).

O coloquialismo e uso de gírias também estão presentes, tirando ainda mais a credibilidade dos argumentos. 
A conclusão não é clara suficiente. Mesmo com um grande esforço por parte do leitor, é praticamente impossível compreender seu pensamento conclusivo: "Portanto, para se botar limites entre a liberdade de informação e o abuso de comunicação devemos exigir parametro que faça das obras uma só e gravitando delas só o pessoa, digo, necessário para nosa vida".

Desta forma, podemos dizer que a produção não progride em termos conteudísticos, bem como argumentativos, devido ao restrito conhecimento de mundo e da estrutura de uma dissertação.

\section{8-9}

\section{Como garantir a liberdade de informação e evitar os abusos nos meios de comunicação?}

Isto é um abuso bastante polêmico porque na teoria se prega a liberdade nos orgãos de comunicação mas na prática não é assim, os abusos são por parte dos empresário que controlam a emprensa escrita e televisiva e também dos próprios reporter que não respeitam os direitos das pessoas.

Se os reportes se mantivessem fiéis aos fatos e escrevessem e mostrassem a verdade, respeitando a autenticidade dos mesmos e respeitando os direitos das pessoas envolvidas, acho que seria um princípio.

Outro aspecto importante para garantir a liberdade de informação e que a emprensa não sofresse prensão por parte de empresários ou governantes.

Se ambos os lados fizessem a sua parte teríamos um emprensa mais verdadeira e digna, onde as pessoas pudessem confiar de que os fatos apresentados fossem verdade, e sem medo de terem seus direitos desrespeitados.

\footnotetext{
ANÁLISE

Uma leitura global do texto revela que não há tantos problemas no que se refere à compreensão, entretanto, falhas no nível estrutural são aparentes, bem como o baixo grau de informatividade.

O texto começa com um pronome demonstrativo que logo faz surgir a pergunta pelo antecedente: isto o quê? Tem-se, pois, a impressão de que o autor considera o tema parte do seu texto, sem contextualizá-lo.
} 
O segundo parágrafo não progride em termos informativos (MR2), pois percebemos que o autor repete as mesmas ideias do primeiro, sem que haja o acréscimo de alguma informação. Além disso, quando há uma tentativa de inserção de novas opiniões, o autor não completa, deixando lacunas no texto: "[...] respeitando os direitos das pessoas envolvidas, acho que seria um princípio.". Não se sabe de que princípio o produtor estaria falando, pois não é mencionado.

Infrações à MR4 também são visíveis. No primeiro parágrafo, o emissor menciona que não há liberdade de informação garantida nos meios de comunicação, mas não fala mais nada sobre isso no decorrer da dissertação.

Falta à conclusão mais concretude das ideias, já que "se ambos os lados fizessem a sua parte" não instaura proposta efetiva à resolução do problema.

\section{3-9}

\section{Meios de comunicação: um instrumento difícil de entender}

Os meios de comunicação estão cada vez mais avançados, devido o número de informações que a cada segundo aumenta ou simplesmente: um número imaginário de notícias que a imprensa move à toda hora. Diante disso, o fiel contribuinte para tal causa, é a mídia, que a cada oportunidade, está lá, fazendo o seu trabalho, porém, às vezes fazendo com que um acontecimento sem importância, vire novidade para todos.

Para se ter informação basta ligar a televisão de sua casa e assistir aos inúmeros programas que as emissoras proporcionam. Perante isso, a mídia explora suas notícias, sem muito se importar com as conseqüências que isso poderá ocasionar, na verdade ela não esta preocupada se tal anuncio irá afetar a vida de uma família humilde ou se dará mais prestigio aos poderosos, com essa atitude, fica claro o objetivo da imprensa perante a sociedade.

Com os programas de televisão, nota-se nitidamente nossa curiosidade pelos meios de comunicação, são eles que nos mostram a realidade do momento, também fazem ver um mundo imaginário, que só esses "criadores" de notícias boas e péssimas nos fazem perceber. Assim sendo, a mídia não possui controle dos seus atos ela quer é passar novidade e ganhar audiência, deve-se evitar abusos nesse meio que é a comunicação, caso contrário a palavra privacidade, irá desaparecer de nosso vocabulário. 
O mundo mudou em termos de meios de comunicação e com isso vieram juntos a "fome" de notícias e sucesso. As informações estão ai. Cabe a cada um saber escolher o que é certo ou errado, o que é abuso e privacidade, é claro, o que podemos usar em nosso cotidiano.

\section{ANÁLISE}

Esse texto não oferece dificuldades de decodificação, embora seja fraco no requisito de argumentação.

A progressão entre os parágrafos um e dois pode ser reconhecida. No entanto, no terceiro parágrafo, embora haja uma conexão com as ideias dos parágrafos anteriores, as últimas orações transmitem ideias que nada correspondem ao que estava sendo dito. Há uma mudança abrupta de assunto.

A metarregra de repetição (MR1) é usada de maneira adequada, tendo em vista que não encontramos repetição demasiada de vocábulos que fazem parte do eixo temático.

As substituições lexicais ocorrem em vários momentos, como no primeiro parágrafo, em que o autor utiliza os vocábulos "mídia" e "imprensa" para se referir aos meios de comunicação. Outra reiteração pode ser verificada no segundo parágrafo, em que o emissor faz a substituição gramatical da palavra "mídia" pelo pronome "ela" e, posteriormente, por “imprensa” (substituição lexical):

a mídia explora suas notícias, sem muito se importar com as conseqüências que isso poderá ocasionar, na verdade ela não esta preocupada se tal anuncio irá afetar a vida de uma família humilde ou se dará mais prestigio aos poderosos, com essa atitude, fica claro o objetivo da imprensa perante a sociedade.

O uso de substituições e elipses pode ser verificado durante todo o texto, podendo, assim, ser reconhecido o recurso adequado de coerência.

A conclusão apresenta acertos e desacertos. Por um lado, retoma coerentemente o assunto dos parágrafos anteriores, embora não apresente uma posição clara sobre eles. Porém, não encontramos uma resolução clara ao questionamento feito no tema, constituindo um tipo de infração à MR4.

\section{9-5}

\section{A Liberdade}


Cada vez mais vem aumentando os meios de comunicação, e se torna muito mais fácil de ficar sabendo o que está acontecendo em todas as partes do mundo.

Podemos utilizar alguns argumentos para poder observar o modo que a imprensa usufrui de seus poderes. A mídia com suas camêras cercam e invadem lugares para gravar um assalto ou uma briga, sem pedir licença abusam da nossa paciência e da comunicação. E assim interfere em nossas próprias opiniões, pois nos faz acreditar que tudo o que ela está mostrando é o correto.

Mas nós temos a liberdade para entender o que está sendo mostrado da maneira que quisermos, temos liberdade para pensar e agir fazer o que achamos certo. Mas para muitos expressar o que pensam é muito difícil, pois não tem argumentos, ou muitas vezes até mesmo por falta de informação.

Portanto, a liberdade de informação deve ser respeitada, para poder expôr, sem se quer sofrer um abuso, ou mesmo uma discriminação.

\begin{abstract}
ANÁLISE
Deve-se mencionar, de imediato, que o restrito conhecimento de mundo do autor interferiu de forma marcante na elaboração do texto, visto que a dificuldade argumentativa associada à falta de conhecimento sobre o assunto culminou na construção de um texto fraco no que se refere à informatividade.

O título parece genérico demais, embora não interfira tanto na coerência do texto.

Não há progressão no primeiro parágrafo (MR2), pois o autor menciona que "cada vez mais vem aumentando os meios de comunicação", mas não explica, nem exemplifica de que forma vem aumentando. $\mathrm{O}$ segundo parágrafo trata de ideias distintas do primeiro, remetendo mais uma vez a infração à MR2.

Bons exemplos do uso adequado da MR1 podem ser encontrados no segundo parágrafo. O autor utiliza a substituição lexical e gramatical, a fim de reiterar o vocábulo "imprensa". Primeiramente, o substitui pelo substantivo "mídia":
\end{abstract}

Podemos utilizar alguns argumentos para poder observar o modo que a imprensa usufrui de seus poderes. A mídia com suas camêras cercam e invadem lugares para gravar um assalto ou uma briga, sem pedir licença abusam da nossa paciência e da comunicação. 
e, posteriormente, pelo pronome "ela": "E assim interfere em nossas próprias opiniões, pois nos faz acreditar que tudo o que ela está mostrando é o correto".

O terceiro parágrafo não estabelece relação alguma com o restante do texto, sendo uma espécie de infração à MR4.

A conclusão mostra claramente a falta de conhecimento do tema, já que percebemos uma determinada confusão de conceitos por parte do autor: "Portanto, a liberdade de informação deve ser respeitada, para poder expôr, sem se quer sofrer um abuso, ou mesmo uma discriminação.". De que forma a liberdade de informação seria "discriminada"? Fala-se de "respeito" à liberdade ou garantia da liberdade?

A deficiência nas principais habilidades pode ser claramente verificada nesse texto.

\section{0-6}

\section{Perigosas Informações}

Atualmente o país vive ligado interiormente aos meios de comunicação de massa, trazendo para dentro das casas toda e qualquer informação "boa e ou ruim". Causando muitos conflitos diretamente ligados ao que se vê e ao que se pode adquirir, por condições financeiras ou até mesmo por não saber "administrar".

Tudo está ligado a eles, em qualquer lugar apresentando as mais diferentes formas de abuso sexual, violência, drogas, rock rool, meio ambiente, entreterimento, não tendo como classificar o que deseja ver ou ouvir. Poluindo assim o corpo com tanta informação perigosa e desnecessária para um melhor desenvolvimento.

Tanta informação tem seu valor importante, contribui para o crescimento social e cultural do país levando idéias que podem ser aprimoradas, levando conhecimento e preocupações para serem discutidos e melhorados.

Como já existem entidades responsáveis para acompanhar o desempenho da mídia, devem se empenhar mais, pois os brasileiros estão vendo e ouvindo informações indesejadas e perigosas, capazes de aumentar a corrupção e outros fatores que agravam o desenvolvimento do país.

\section{ANÁLISE}


Estamos diante de um texto que apresenta ideias muito confusas, devido à falta de conexão entre orações, parágrafos e ideias.

O texto apresenta problemas, primeiramente, pelo uso desequilibrado de repetição no primeiro e segundo parágrafos, ocasionado pela falta de revisão ou mesmo criatividade do produtor. Em apenas cinco linhas (as primeiras do texto), o autor faz a repetição propriamente dita três vezes do vocábulo "ligado":

Atualmente o país vive ligado interiormente aos meios de comunicação de massa, trazendo para dentro das casas toda e qualquer informação "boa e ou ruim". Causando muitos conflitos diretamente ligados ao que se vê e ao que se pode adquirir, por condições financeiras ou até mesmo por não saber "administrar". Tudo está ligado a eles, em qualquer lugar apresentando as mais diferentes $[\ldots]$

As lacunas textuais são diversas, pois o produtor expõe uma ideia, a qual necessita de explicação ao leitor, mas isso não acontece. No primeiro parágrafo, temos um exemplo, quando o emissor menciona: "Causando muitos conflitos diretamente ligados ao que se vê e ao que se pode adquirir, por condições financeiras ou até mesmo por não saber “administrar”." Logo, o leitor se pergunta: administrar o quê?

Pode-se dizer que entre o primeiro e o segundo parágrafos há certa progressividade, tendo em vista que o autor retoma o assunto sobre os "meios de comunicação" através da substituição gramatical (pronome "eles"), e insere novas informações, embora não sejam tão informativas e se apresentem um tanto confusas; mas apesar disso, incoerências internas acabam ocorrendo, já que o autor não dá continuidade às ideias que expõe. Ainda no segundo parágrafo, não se sabe ao certo o que o autor quer dizer com: "poluindo o corpo". Além disso, verificamos, nesse trecho, uma infração à MR3, pois o emissor diz: "Poluindo assim o corpo com tanta informação perigosa e desnecessária para um melhor desenvolvimento.”.

Embora não saibamos de que desenvolvimento o autor estava falando, qualquer leitor pressupõe que informações perigosas e desnecessárias não causam desenvolvimento.

Falta, pois, ao autor maior conhecimento e reflexão sobre o tema abordado, visto que não se posiciona em relação ao assunto.

\section{1-1}


A mídia invade nossas vidas todos os dias, nos trazendo notícias, informações e distração. Porém, o serviço das telecomunicações também vem sendo alvo de muita polêmica e censura, conseqüência na maior parte, da exposição de temas ou assuntos considerados impróprios no ponto de vista de alguns.

Um caso típico que pode ser citado ocorrido neste ano, em que o presidente da República, Luiz Inácio Lula da Silva foi taxado de alcoólatra por um jornalista norteamericano. A atitude de Lula em tirar o visto do referido jornalista foi tanto aplaudida como condenada, sob o pretexto de que é livre a liberdade de informação, afinal, desde o fim da Ditadura Militar não havia mais expressão à imprensa.

No entanto, até que ponto é correto invadir a intimidade de alguém expondo sua vida ao público sem a sua autorização?

Dessa forma é possível concluir que deve-se sim, existir liberdade de informação, com a condição de que esta não afete a moral de quem está envolvido no assunto, porque uma coisa e passar as informações tal como aconteceram, a outra é denegrir as mesmas em busca de audiência ou ibope. Afinal, como dizem, a liberdade de uma pessoa vai até onde começa a liberdade da outra.

\section{ANÁLISE}

Esse texto apresenta boas qualidades no que diz respeito às regras de coerência, embora também contenha algumas falhas no que se refere à estrutura.

Quanto aos requisitos de coerência, encontramos exemplos de uso razoável. Já na introdução, o substantivo "mídia" é reiterado através do termo "telecomunicações", configurando um bom exemplo de substituição lexical.

O texto inteiro segue uma linha de pensamento que, se não é rica de informatividade, também não peca pela circularidade do discurso. O tema é articulado coerentemente com a introdução de novas informações (MR2).

O texto encontra-se bem articulado, tanto no plano da expressão, como no plano lógico-semântico. A relação entre as partes do texto (MR4) não apresenta problemas, assim como não há contradições (MR3) na manutenção temática, nem contradições léxicosemânticas tão graves.

Temos, pois, um texto com satisfatório grau de coerência. 


\section{7-5}

\section{Como garantir a liberdade de informação e evitar os abusos nos meios de comunicação?}

Em primeiro lugar os meios de comunicação não podiam expor tanto a vida de ninguém seja essa pessoa rica ou pobre. Os meios de comunicação também não tá nem aí para o que, que ela está divulgando muitas vezes ela está ajudando a algumas pessoas entrar no mundo da prostituição das drogas.

Os adolescentes estam aprendendo cada vez mais há não obedecer seus pais, pois, eles estão vendo e ouvindo todos os dias noticias as quais eles acham que devem seguir por isso não respeitam ninguém.

Agora para garantir liberdade de informações, deveria ser feito uma passada geral nas notícias e depois uma explanação sobre as principais.

E para evitar os abusos nos meios de comunição, deveria ser dado uma olhada nos escriptos das novelas, nos roteiros dos demais programas a serem desenvolvidos e depois sim dizer se pode ou não ir para o ar aquele programa ou novela.

\section{ANÁLISE}

Esse texto apresenta muitas falhas no que se refere à coesão e coerência, devido à extrema dificuldade do aluno em utilizar a modalidade escrita da língua e pelo seu restrito conhecimento do assunto. Além da desestruturação formal, há problemas no aspecto lógicosemântico. De fato, é possível localizar infrações às quatro metarregras ao longo do texto.

Uma leitura global revela uma desarticulação entre a maior parte do texto e o tema proposto no "título": "Como garantir a liberdade de informação e evitar os abusos nos meios de comunicação?". Apenas nos dois últimos parágrafos são mencionadas, mesmo que superficialmente, ideias sobre o assunto (MR4).

O texto inicia com "Em primeiro lugar", quando deveria antes introduzir o tema, para depois argumentar.

A repetição da expressão "os meios de comunicação" poderia ter sido efetuada de maneira mais criativa; da forma que está, caracteriza uma espécie de infração à MR1.

O mesmo ocorre quando o autor faz substituições inadequadas ao tentar reiterar vocábulos. Isso acontece no primeiro parágrafo, quando o produtor substitui o mesmo termo (citado anteriormente) pelo pronome "ela", causando inadequação ao texto: "Os meios de 
comunicação também não tá nem aí para o que, que ela está divulgando muitas vezes ela está ajudando a algumas pessoas entrar no mundo da prostituição das drogas".

O uso impensado do pronome "eles", no segundo parágrafo, acaba por tornar o texto confuso pelo fato de encontrarmos dois antecedentes. Embora o leitor possa pressupor que seu referente seja "adolescentes", o mais próximo dos pronomes é "seus pais", podendo confundir o leitor.

Falta conexão entre os parágrafos. Além disso, o terceiro parágrafo é bastante obscuro, ficando difícil para o leitor compreender o objetivo do autor: "Agora para garantir liberdade de informações, deveria ser feito uma passada geral nas notícias e depois uma explanação sobre as principais".

A conclusão também é bastante fraca no que se refere à argumentatividade. $O$ coloquialismo e a oralidade, igualmente, contribuem para a diminuição do poder de persuasão do autor.

\section{6-8}

\section{Abusos sem pudor.}

O papel da imprença, é a informação mas isso não da o direito dela sair por ai abusando e invadindo a vida íntima de ninguem, sejá pobre ou seja rico. Deve haver um certo limite em relação ao seu papel.

A imprença de hoje sai pelas ruas da cidade, e dos bairros atrás de reportagens e fatos que fazem aumentar o seu ibope e audiência. Mas, não sabem que em busca destes fatos uma pessoa ou até mais saem prejudicada pelo abuso da imprença. O alvo para esse tipo de abuso, são aquelas pessoas completamente desinformadas, aquelas que não sabem ler, escrever são as preferidas para esse tipo de brincadeira por parte da imprença, que só ta ali para nos transmitir tudo isso.

Os abusos de comunicação, se da pelo simples fato da pessoa ser pobre, essas pessoas acham que só porque são pobres e vão aparecer na mídia, pensam que algo vai ser feito em relação a seu estado. Pode até ser feito, mas por parte da imprença, que se aproveita deses fatos para incrementar uma coisinha a mais e acabar prejudicando ainda mais a imagem daquele cidadão honesto. O povo é pobre mas não é burro, e acaba se vingando da imprença de um jeito errado. 
A imprença, no seu papel de informar, não pode sair prejudicando, e abusando de pessoas "pobres". Tem de haver um certo processamento na hora de transmitir as imagens esses tipos de abuso não só acaba prejudicando a pessoa, mas como a propria imprença.

\section{ANÁLISE}

Esse texto apresenta problemas, primeiramente, pelo uso desequilibrado do requisito de repetição. A reprodução dos vocábulos, desejada por demonstrar a retomada e a manutenção da mesma sequência temática, fica empobrecida pelo uso automático das mesmas palavras. Em todo o texto, temos oito ocorrências da palavra "imprensa", quando o desejável era que ela fosse retomada através de mecanismos de pronominalização e outros.

No primeiro parágrafo, verificamos que a falta de palavras adequadas à situação descrita proporciona incoerência ao texto, como quando o autor diz: "O papel da imprença, é a informação" e não explica a relação da imprensa com a informação.

No segundo parágrafo, quando o emissor diz: "O alvo para esse tipo de abuso, são aquelas pessoas completamente desinformadas", logo surge a pergunta pelo antecedente de "esse tipo de abuso", mas não o encontramos.

Um problema com relação à aceitabilidade pode ser verificado no terceiro parágrafo, tendo em vista que o autor faz uma generalização, quando menciona: "Os abusos de comunicação, se da pelo simples fato da pessoa ser pobre [...]”.

Em todo o texto nos deparamos com desvios à norma e uso da oralidade, o que diminui o poder persuasivo do autor. Tal como muitas partes do texto, a conclusão também se apresenta vazia e fraca no que se refere à argumentatividade.

\section{2-0}

\section{Informação e Comunicação sem abusos de liberdade}

No Brasil atualmente vem demonstrando grande preocupação em parte de cada pessoa, ter sua própria liberdade de informação, sem ocorrer em meios de comunicação. É preciso buscar nossos direitos atravéz de leitura de jornais ou até mesmo de canais de televisão que nos demonstrem a realidade de nosso país.

Com certeza sem o direito de nós mesmos se expressar de maneira própria as nossas opiniões iremos no futuro nos prejudicar por que não iremos nos se preocupar diante os 
problemas que nos cercam como brigas de famílias, o estupro, o tráfico de drogas, que no diaa-dia está aumentando cada vez mais. Devemos ter mais argumentos para enfrentar a realidade como fazem por exemplo "Suécia e Grâ-Bretanha" tendo empresas de jornais com opiniões privadas sem sair com mentiras ou ser corruptos.

Ao nosso redor encherguemos que pessoas que expressam a sua parte intelectual, artística e científica está vivendo uma vida mais fácil por que sabe demonstrar sua coerência com a liberdade de suas palavras é claro sem fugir da realidade e sem prejudicar ao próximo emoscionalmente e fisicamente, assim iríamos queimar nossa imagem diante à sociedade e iriamos violar a lei de nosso país.

No entanto, para garantirmos a nossa liberdade de informacão sem usar os abusos de comunicação precisamos primeiramente ser coerentes com nós mesmos, mostrando as nossas opiniões, sem fugir dos assuntos da realidade que estão cercando no nosso cotidiano. E por segundo lugar precisamos saber em quem estamos votando, por que o governo é a fonte de tudo nessa vida, usando a um bom caminho ou para o mal caminho.

\section{ANÁLISE}

O texto surpreende já pelo título: "Informação e comunicação sem abusos de liberdade". Além disso, é nítida a extrema dificuldade do aluno em utilizar aceitavelmente a modalidade escrita da língua portuguesa.

Os desvios em nível formal, especialmente no tocante à ortografia, regência e pontuação são graves, mas o que chama ainda mais a atenção é a incapacidade do produtor em conseguir articular suas ideias, bem como as palavras de seu texto.

O primeiro período do texto é absolutamente incompreensível: "No Brasil atualmente vem demonstrando grande preocupação em parte de cada pessoa, ter sua própria liberdade de informação, sem ocorrer em meios de comunicação.”, por isso, vemos que além da desestruturação formal, há problemas no aspecto lógico-semântico.

Mais uma vez, temos um texto que não atingiu o objetivo esperado através da proposta do ENEM. A questão da liberdade de expressão não é discutida, tendo em vista que o produtor não possui o real entendimento dessa expressão.

A disposição das palavras encontra-se mal articulada, o que dificulta a compreensão pelo leitor, como quando o autor menciona: "Ao nosso redor encherguemos que pessoas que expressam a sua parte intelectual, artística e científica está vivendo uma vida mais fácil por que sabe demonstrar sua coerência com a liberdade de suas palavras [...]". 
Deparamo-nos com uma sequência de incoerências, já que o produtor não consegue se exprimir de maneira satisfatória.

Certas expressões precisam ser definidas após serem exploradas como argumento, pois sem o esclarecimento o texto se torna confuso; expressões como: "Precisamos primeiramente ser coerentes com nós mesmos [...]" podem ser encontradas durante todo o texto, por isso podemos dizer que a produção apresenta em toda sua extensão lacunas textuais, que mesmo completadas pela ação interpretativa do leitor, dificultam o entendimento do texto.

Revelam-se, pois, problemas com relação ao domínio de habilidades de leitura e escrita por parte do autor.

\section{9-9}

\section{Liberdade de Informação}

A liberdade de informação, que é cada vez mais atual, vem acarretando abusos nos meios de comunicação que invadem a vida das pessoas pelas melhores e mais atuais noticias, sem levar em conta os conceitos e princípios de cada um com relação a publicidade, apenas tendo em vista a melhor notícia.

A mídia tem liberdade de informação sobre tudo e todos porém esta não é uma liberdade total por isso vem sendo estudada. Classes mais baixas tem seu intimo facilmente revelado pois a mídia acha que tem poder de invadir e relatar os acontecimentos sem permição de ninguém porém em bairros nobres onde existem classes altas que tem condições de fazer com que a mídia não mostre a realidade dos fatos ou mostrando histórias distorcidas que favoreçam o entrevistado ou amenisem sua participação, culpa ou inclusão o caso em relação ao espectador.

Para garantir a liberdade de informação sem que interfira na privacidade das pessoas deveria-se elaborar um consenso entre ambas as partes, vendo que não necessitaria criar leis e impo-las contra a imprensa e sem formular uma relação de ética entre mídia e população a ser respeitada.

\section{ANÁLISE}

Percebemos, nesta redação, que o poder de persuasão do autor é ineficiente devido ao baixo grau de informatividade de seu texto. 
Embora tenhamos uma introdução clara ao tema, o final do parágrafo peca por não ser esclarecedor: "sem levar em conta os conceitos e princípios de cada um com relação à publicidade, apenas tendo em vista a melhor notícia".

O início do segundo parágrafo não progride, tendo em vista que o autor inicia uma ideia e não a finaliza, introduzindo abruptamente outro assunto (MR2 - MR4).

No segundo período do segundo parágrafo, também nos deparamos com a incontinuidade do texto. O uso da conjunção adversativa "porém" nos faz inferir que uma ideia contrária à anterior aparecerá, mas isso não acontece:

Classes mais baixas tem seu intimo facilmente revelado pois a mídia acha que tem poder de invadir e relatar os acontecimentos sem permição de ninguém porém em bairros nobres onde existem classes altas que tem condições de fazer com que a mídia não mostre a realidade dos fatos ou mostrando histórias distorcidas que favoreçam o entrevistado ou amenisem sua participação, culpa ou inclusão o caso em relação ao espectador.

A metarregra da não-contradição é infringida no último parágrafo, em que o emissor diz:

Para garantir a liberdade de informação sem que interfira na privacidade das pessoas deveria-se elaborar um consenso entre ambas as partes, vendo que não necessitaria criar leis e impo-las contra a imprensa e sem formular uma relação de ética entre mídia e população a ser respeitada.

Levando-nos a imaginar, como seria "elaborar um consenso" sem estar respaldado pela lei?

Vemos, pois, que faltou ao aluno conhecimento de mundo suficiente para a produção de um texto de qualidade e com informatividade, o que foi crucial para a elaboração inadequada e ineficaz da redação.

\section{1-0}

\section{Informação. Não Abuso}

Hoje em dia muitas pessoas estam vivendo como se estivessem em um "Big Brother". Num mundo onde as chamadas "celebridades" estão sempre na boca do povo. Isso tudo é um prato cheio para a mídia. 
Sabemos que existe o direito de imprensa e que a imprensa é um veículo de informação completo, indispensável na vida de todas as pessoas, mas perguntamos: até onde a imprensa pode entrar em nossa privacidade.

As pessoas pedem e com direitos, para terem suas vidas privada preservada mas na grande maioria das vezes não são atendidas.

Até hoje não foi possível estabelecer um equilíbrio entre a informação e o abuso contra as pessoas.

Sabemos que esse equilíbrio só irá acontecer quando a imagem não for tão importante e tão valorizada, somente quando as pessoas tiverem conciência que ser famoso não é tudo, só irá acontecer quando as pessoas perceberem que a vida pessoal é mais importante do que apenas alguns minutos na televisão ou em fatos de revistas.

A imprensa também precisa fazer a sua parte. Ela precisa entender que as vezes privasidade tem que ser respeitada.

Sabemos que essa é difícil, mas não impossível, e por isso vamos continuar pedindo: informação sim, abuso não.

\section{ANÁLISE}

Aparentemente, o texto não apresenta problemas em relação à decodificação, no entanto, muitas falhas podem ser encontradas.

A falta de rigor linguístico, demonstrada através do não uso de certo padrão linguístico é aparente e acaba por diminuir o poder de persuasão do autor. A exemplo disso, temos o coloquialismo verificado no trecho: "Num mundo onde as chamadas "celebridades" estão sempre na boca do povo. Isso tudo é um prato cheio para a mídia".

Tem-se a impressão de que o produtor limita seu conceito de "meios de comunicação" à televisão, já que menciona ideias relacionadas a "Big Brother", "celebridades", "famosos" entre outras.

Até o quarto parágrafo, podemos verificar que não há retomada, nem progressão em relação aos pensamentos inseridos (MR1 - MR2).

No segundo parágrafo, uma infração à MR2 é nítida no momento em que o produtor diz que "a imprensa é um veículo de informação completo", pois, além de não explicar o porquê da "completude", não dá seguimento ao assunto. 
O único momento do texto em que a progressão e conexão entre os parágrafos acontece (MR2 - MR4) é do quarto para o quinto parágrafo, em que o autor retoma (MR1) o vocábulo "equilíbrio" e expõe seu ponto de vista.

No entanto, o grau de informatividade do texto é bastante baixo, sendo insuficiente para persuadir o leitor.

\section{2-0}

\section{Dura Realidade}

Hoje em dia, os meios de comunicação nos revelam uma dura realidade. Antigamente estes nos traziam diversão, curiosidades, cultura e informação. Com o crescimento das cidades e da população, cresceu também todos os tipos de violência existentes. Estas se tornam alvos de jornalistas, que ao acontecer algo já estão filmando e fazendo reportagens que vem diretamente aos olhos e ouvidos da população.

O mundo esta se transformando, pois as notícias nos passam horrores todos os dias. A equipe jornalista não deveria pensar só na concorrência de ser sempre primeiro na hora de publicar as notícias e de passar a informação ao publico ouvinte, acredito que deveria haver um horário adequado para este tipo de notícia, pois é um péssimo exemplo para nossas crianças, que darão continuidade a este mundo.

Infelizmente não existe uma lei específica para este tipo de informação, pois é necessário a população estar atualizada com as notícias do mundo, mas deveria haver um horário especifico para isto, pois afinal hoje em dia existe tantos meios de comunicação. Acredito que todos devem se concientizar e fazer sua parte pois a educação de nosso mundo e de nossas crianças que está em jogo, ou seja em nossas mãos.

\footnotetext{
ANÁLISE

Macroestruturalmente, o texto apresenta coerência e, embora as ocorrências de ideias sejam já conhecidas pelo receptor, ou seja, previsíveis, a produção apresenta boa qualidade no que diz respeito às regras de coerência.

Mesmo que implicitamente, os primeiros períodos do texto apresentam progressividade:
} 
Hoje em dia, os meios de comunicação nos revelam uma dura realidade. Antigamente estes nos traziam diversão, curiosidades, cultura e informação. Com o crescimento das cidades e da população, cresceu também todos os tipos de violência existentes. Estas se tornam alvos de jornalistas, que ao acontecer algo já estão filmando e fazendo reportagens que vem diretamente aos olhos e ouvidos da população.

Se nessa passagem o autor tivesse usado um indicador temporal (como fez no início: antigamente) para designar a mudança atual, tornaria o texto mais claro para o leitor.

Exemplos bons e ruins do recurso da MR1 podem ser verificados no primeiro parágrafo. O uso adequado da reiteração ocorre quando há substituição gramatical do termo “meios de comunicação" pelo demonstrativo "estes", garantindo, assim, a manutenção temática. No entanto, quando o produtor usa o pronome "estas" para substituir o termo "todos os tipos de violência" acaba por falhar devido à falta de atenção à variação adequada do pronome.

A progressão entre o segundo e o terceiro parágrafos também é aparente. Embora falte, por parte do emissor, uma explicação sobre "[...] as notícias nos passam horrores", claramente percebemos que quando menciona, no parágrafo seguinte, "Infelizmente não existe uma lei específica para este tipo de informação", trata-se dessa ideia.

Podemos dizer, pois, que o texto encontra-se bem articulado. Somente a conclusão, embora não configure dano à questão da coerência, peca pela ausência de informatividade e concretude no que diz respeito a uma suposta solução para o problema. Além disso, falta ao final a retomada ao tema, que é primordial para a finalização.

\section{6-0}

\section{A Imprensa}

A falta de respeito de algumas pessoas ligadas a midia com cidadãos brasileiros é uma coisa Absurda. A invasão de privacidade não deveria acontecer, pois a privacidade é um direito de todo brasileiro.

A imprensa deve publicar suas matérias, mas respeitando ao próximo. A midia transmite noticias, que trazem ibope, estão mais preocupados em ganhar ibope do que própriamente a transmissão da noticia para o telespectador ouvinte. 
Leis que proíbem a invasão de privacidade já existem mas muitas pessoas humildes se desconhecem destas leis, deixando que a imprensa perturbe suas vidas, e desconhecendo de seus direitos.

Ha noticia deve ser passada ao ouvinte, mas não é preciso que haja tanta valorização dos fatos por parte da imprensa brasileira, que por causa de ibope expõe famílias e pessoas a midia, perturbando a vida desses individuos, o que de ipótese alguma deveria ser feito.

\begin{abstract}
ANÁLISE
Esse texto apresenta problemas, primeiramente, pelo uso desequilibrado do requisito da repetição (MR1). O uso automático de vocábulos como "mídia", "privacidade", "imprensa" e "ibope" acabam por empobrecer o texto, pois demonstram a falta de conhecimento de mundo do autor e do assunto abordado.

Não há uma introdução clara ao tema. Além disso, o primeiro período do texto pressupõe questionamentos por parte do leitor. O produtor afirma que: "A falta de respeito de algumas pessoas ligadas a midia com cidadãos brasileiros é uma coisa Absurda", mas não explica, nem esclarece o porquê (MR2).

Nota-se, também, certa desarticulação entre o texto e parte do tema proposto, haja vista que o autor não menciona em nenhum momento a questão da liberdade de informação (MR4).

Percebemos, pois, que a falta de conhecimento do autor ocasionou repetições de ideias, grau de informatividade baixo e falta de argumentação, já que não propõe algo concreto em relação aos abusos dos meios de comunicação.
\end{abstract}

\title{
0273922-4
}

\section{Liberdade ou expressão ou de exposição?!}

Com a concorrência cada vez maior entre profissionais e empresas, os jornalistas fazem de tudo para ter o seu lugar ao sol, passando por cima da ética e dos princípios morais para conseguir seu destaque. Já dizia um grande pensador "o teu direito vai até onde começa o do outro"; muito inteligente este cara! Mas infelizmente para certas pessoas isso é irrelevante o que importa mesmo é que "os fins justificam os meios" (Maquiavel). 
Com o objetivo de mostrar primeiro, os jornais confundem a liberdade de expressão com a liberdade de exposição, que não existe, privacidade não é um bem pessoal; direitos então nem se fale, os direitos que são relevantes são os convenientes a cada um de seus interesses.

As reportagens acabam se destacando por destacar o outro e as banalidades da vida, invadindo sem pedir permissão o pessoal de cada indivíduo. Mas isso não é importânte; só o que é importânte é se o objetivo foi alcançado: a notícia chegou primeiro, conseguiu destaque e teve repercursão, então está tudo bem. E depois que o tumúltuo passa? O que acontece? Não acontece nada! A notícia teve sua divulgação, e a pessoa que teve seu problema exposto continua na mesma, a única diferênça é que depois disso seu problema é público; mas a resolução deste continua sendo dela e somente dela.

\section{ANÁLISE}

O primeiro fato que deve ser destacado, nessa redação, é o uso indiscriminado de frases prontas, o que revela uma percepção de mundo feita através dos olhos alheios e não do próprio olhar do autor. O resultado disso é um texto despersonalizado, sem originalidade. Esse problema não aconteceria se o autor evitasse frases, expressões e opiniões de valor desgastadas e banais.

O primeiro parágrafo é rico em exemplos desse tipo: “[...] o seu lugar ao sol”, “o teu direito vai até onde começa o do outro” e “os fins justificam os meios”.

Além disso, podemos notar que há certa generalização quando o emissor diz: "os jornalistas fazem de tudo para ter o seu lugar ao sol, passando por cima da ética e dos princípios morais para conseguir seu destaque". Desta forma, o lugar comum associado à generalização acaba por desvalorizar o texto, no que se refere à argumentatividade.

No terceiro parágrafo, encontramos uma grave infração à MR3, quando o autor menciona: "privacidade não é um bem pessoal; direitos então nem se fale, os direitos que são relevantes são os convenientes a cada um de seus interesses". Qualquer tipo de leitor pode reconhecer nesse trecho a incoerência do produtor.

Não há retomada, nem progressão entre os parágrafos (MR1 - MR2). Muitas lacunas são deixadas pelo produtor, ocorrendo vários questionamentos que não podem ser respondidos devido à falta de clareza do texto.

Em suma, verificamos que a ausência de conhecimento de mundo do aluno contribuiu fortemente para a elaboração desse texto, que peca em vários sentidos. 


\section{5-0}

\section{Problemas que devem ser reajustados}

Os problemas que se deparamos em nosso dia-a-dia, vem tornando um caso estupendo na maioria das vezes. Por falta de respeito magoamos pessoas que não tem culpa alguma, pois estão nos seus simples gesto de trabalhar e buscam através de nós uma pequena idéia.

Há diferentes tipos de pessoas em nosso país, aquelas o qual são civilizadas, que quando são (***) a dar uma entrevista, não fazem caretas e colocam sua idéia sobre determinado assunto, dando aí então ânimo aos jornalistas. No meu ponto de vista, pessoas como essas deveriam ser elogiadas, por possuírem um caráter de boa qualidade.

Devemos criar um plano de governo que faça com que nossos artistas e jornalistas tenham mais facilidade em agir com o povo, dando mais espaço as pessoas darem seu ponto de vista, sem gerar transtornos e imprudência social.

Assim, então construir-te-ão um mundo digno, fazendo com que as pessoas não se tornem monótonas, porque ficar zangado só leva a ignorância, e não é isso que queremos né?

\section{ANÁLISE}

O texto surpreende, mesmo antes de uma análise mais aprofundada, devido à extrema dificuldade do aluno em expor suas ideias de maneira clara.

Uma leitura global revela uma quase total desarticulação entre o texto e o tema proposto. A tentativa do autor de utilizar uma linguagem mais elaborada acaba por prejudicálo, tendo em vista que este não detém o real significado vocabular, bem como utiliza a norma de maneira inadequada. Exemplos a esse respeito podem ser verificados no primeiro e último parágrafos. No primeiro, o autor menciona: "Os problemas que se deparamos em nosso dia-adia, vem tornando um caso estupendo na maioria das vezes". Este caso pode ser considerado até uma infração à MR3, já que um problema jamais poderia ser considerado como "estupendo". No último, numa tentativa falha de erudição, o produtor utiliza a mesóclise de maneira inadequada: "Assim, então construir-te-ão um mundo digno, fazendo com que as pessoas não se tornem monótonas, porque ficar zangado só leva a ignorância”.

Além do primeiro parágrafo não fazer uma introdução ao tema, não é esclarecedor, sendo que o leitor sente dificuldade em compreendê-lo. 
A falta de conhecimento sobre o assunto é extrema, o que torna o texto totalmente insatisfatório no que diz respeito ao objetivo proposto.

\section{2-3}

\section{A Mídia Em Nossas Vidas}

É dever dos meios de comunicação nos deixar bem informados sobre os ultimos acontecimentos em nosso país. Muitas matérias feitas por jornalistas já ajudaram a polícia a prender traficantes, corruptos entre outros. Porem, atualmente a mídia está invadindo a privacidade de pessoas, publicando matérias sem o concedimento das mesmas.

O trabalho da mídia é essencial em nosso país. Ela está em toda parte e é atravez dela que nos mantemos informados de tudo o que ocorre por aí. Não é raro vermos notícias, reportagem de jornalistas que mesmo correndo perigo de vida, se disfarçam de bandidos para denunciar a sociedade a ação destes. Em um trabalho que alem de informar a sociedade ajuda a polícia.

Porem essa mesma mídia que nos informa está tirando nossa privacidade. Uma vez que muitos jornalistas invadem casas, tiram fotos de pessoas humildes para fazerem suas reportagens sem a permissão das mesmas. Outros espionam a vida de pessoas com o intuito de descobrir o máximo sobre a vida pessoal dela para depois exibir as descobertas em programas de televisão.

Enfim essa mesma mídia que nos informa, nos deixa por dentro de tudo também invade a privacidade de pessoas publicando reportagens sem o consedimento das mesmas. Assim para termos uma mídia que nos informe e que ao mesmo tempo nos respeite temos que acabar com esse abuso punindo os responsáveis por ele, uma vez que invadir a privacidade de alguém, publicando fotos, reportagens sem o seu consedimento é um crime.

\section{ANÁLISE}

Embora o grau de informatividade do texto seja baixíssimo, no que diz respeito às regras de coerência, podemos encontrar boas qualidades. Falhas também são encontradas, mas o leitor percebe claramente o que o autor quer dizer.

Em relação à MR1, encontramos exemplos bons e ruins desse requisito de coerência. No segundo parágrafo, o autor faz uso da substituição gramatical, quando utiliza o pronome 
"ela" e "dela" a fim de reiterar "mídia": "O trabalho da mídia é essencial em nosso país. Ela está em toda parte e é atravez dela que nos mantemos informados de tudo o que ocorre por $a \hat{\imath}$ '. No entanto, o emissor utiliza o termo "meios de comunicação" apenas uma vez, sendo que o substantivo "mídia" é reiterado cinco vezes no decorrer da escrita, configurando falta de revisão ou mesmo desconhecimento de sinônimos.

Outra infração pode ser verificada quando o autor repete as mesmas ideias no primeiro e segundo parágrafos, não havendo, destarte, progressão (MR2).

O terceiro parágrafo faz uma breve retomada de informações do primeiro e acrescenta novas ideias, caracterizando uma progressividade ao texto. No entanto, logo em seguida, no último parágrafo, o emissor acaba repetindo os mesmos pensamentos, sem fazer uma conclusão apropriada.

Em suma, o texto apresenta em toda sua extensão lacunas textuais, que mesmo complementadas pela ação interpretativa do leitor, dificultam o entendimento do texto. Revelam-se, pois, problemas com relação ao domínio de habilidades de leitura e escrita por parte do autor, além do pouco domínio da estrutura do texto escrito.

\section{4-1}

\section{A Informação}

A informação é a maior arma da população contra todo tipo de injustiça, porém passível de abusos deturpações, foi com o processo de globalização que ficamos a par do que acontece ao nosso redor e no mundo, pois com o direito da liberdade de imprensa a, mídia nos informa continuamente, mas para que a informação não sirva para nossa própria destruição deve ser utilizada de modo a não vir contra os nossos direitos.

Muitos anos se passaram de lutas e reinvindicações até que conseguíssemos a tão sonhada liberdade de imprensa. Durante a ditadura a mídia era subjulgada, perseguida e sensurada. Mas com a democracia conseguimos o direito de se expressar. A mídia se libertou e passou a cocientar a população, a informa-la, a alerta-la, passou a desempenhar um papel crucial no denuncio da violência, corrupção, além de divertimento.

Mas a liberdade de informação precisa antes de tudo ser bem utilizada como quase tudo pode ser comunicado, ser informado, muitas coisas são deturpadas e muitos dramas pessoais ou sociais são usados de forma à promover grandes empresas privadas, que dominam 
nosso sistema de comunicação. Assim o direito da pessoa humana deve ser assegurado e respeitado, cabendo a ela antes de mais nada exgigi-lo.

Assim podemos concluir que a liberdade de informação é uma arma importante contra as injustiças, desde que canalizadas de forma crítica buscando saber até onde vão com meias verdades, atuando assim como fiscais da mídia, buscando dela o máximo respeito da pessoa.

\section{ANÁLISE}

Embora em alguns momentos faltem conectores adequados, o texto não apresenta dificuldades com relação à decodificação.

Muitas informações poderiam ser mais bem explicadas pelo autor, a fim de atribuir mais clareza e credibilidade a seu texto.

No início da produção, o emissor menciona que "a informação é a maior arma da população contra todo tipo de injustiça", mas não nos dá exemplos dessas injustiças para serem confirmadas ou negadas.

Podemos verificar certa progressão entre o primeiro e o segundo parágrafos, pois este retoma a questão do direito conquistado citado naquele, e insere novas informações ao texto, mencionando o papel da imprensa (MR2).

Bons exemplos de reiteração podem ser verificados durante o texto: "Assim o direito da pessoa humana deve ser assegurado e respeitado, cabendo a ela antes de mais nada exgigi-lo".

O único caso em que o autor poderia ter sido mais criativo é o da repetição propriamente dita do vocábulo "mídia", que foi utilizado diversas vezes.

A conclusão peca por não haver concretude na proposta do autor, mas o texto encontra-se bem articulado e sem contradições.

\section{7-7}

\section{Liberdade de Informação}

Para garantir a liberdade de informação é necessario que os profissionais estejam muito bem preparados e informados do fato que vai ser exposto ao mundo.

Sem que haja constranjimentos entre a imprensa e os telespectadores. 
Porque infelismente as informações chegam em nossas casas totalmente retorcidas e cendo que muita das vezes aquela informação nem sem verdadeiras.

Sendo que muita das vezes os profissionais de telecomunicações vão as ruas com suas câmeras e maquinas fotográfica tirando fotos e filmando lugares despresivéis entrepistando e invadindo o intimo das pessoas e da comunidade, assim eles se sentem os donos do mundo.

Mais tudo isso ocorre porcausa de uma simples palavra midia, que é delas que eles precisam saber até aonde é o límite e ate aonde vamos respeitar o proximo.

Com certesa seguindo todos esses critérios citados a imprensa passa a ser mais respeitada e valorizada assim ganhando a credibilidade e a confiança dos telespectadores ou melhor da comunidade.

Vamos respeitar os direitos e deveres de todos.

\section{ANÁLISE}

O primeiro aspecto dessa redação que deve ser destacado se refere à conexão dos parágrafos e ideias expostas pelo autor. Do primeiro ao quarto parágrafo, o produtor não faz uso de conectores, não garantindo, dessa forma, a continuidade do texto e a sequência interligada de suas partes, abrindo mão do recurso de coesão.

O segundo parágrafo encontra-se totalmente desarticulado: "Sem que haja constranjimentos entre a imprensa e os telespectadores", configurando uma infração à MR4. Os termos: "sem que haja", "porque", "sendo que", no início de parágrafos, proporcionam o mesmo problema.

Os desvios à norma também são aparentes, muitas vezes dificultando o entendimento do texto pelo leitor.

O uso indevido da MR1 pode ser encontrado diversas vezes. Temos um exemplo no quinto parágrafo, quando o produtor menciona: "Mais tudo isso ocorre porcausa de uma simples palavra midia, que é delas que eles precisam saber até aonde é o límite e ate aonde vamos respeitar o próximo". A substituição da palavra "mídia" pelo pronome "delas" é ineficaz devido à flexão de número utilizada de maneira inadequada.

O penúltimo parágrafo também é falho, pois informa que: “Com certesa seguindo todos esses critérios citados a imprensa passa a ser mais respeitada e valorizada", no entanto, se o leitor procurar os critérios citados, não os encontra, tendo em vista que não foram claramente mencionados. 
Percebemos, pois, que não há conhecimento de mundo suficiente para o aluno produzir um texto argumentativo de qualidade sobre o tema proposto. Além disso, é necessário que o produtor se familiarize com a modalidade escrita da língua portuguesa.

\section{6-3}

\section{Meios de comunicação Problema ou solução}

"Sorria você está sendo Filmado"! Atualmente as pessoas Têm pedido sua liberdade atraves do sistema de comunicação, são reportes com a motivação de chama à atenção da população para seus programas, jornais, revistas etc., usando o drama das pessoas humildes da sociedade que sem conhecimento, não aborda a situação em que está sendo colocada a sua vida, exposta a toda uma mídia que está pronta para auto-te-condena ou te absorve ou (te fazer famoso), bastar você querer, um sistema que só os fortes sobrevivem.

Será que a postura de alguns reportes que faz a mídia e correta? A onde a polícia vai os reportes vão também, uns puchão os revolves para aborda os suspeitos, eles as câmeras e já estão filmando. "Essa não é a mídia que queremos diz a população em algum lugar do país", No Brasil, existe o observatório da imprensa - entidade civil não governamental e não partidária -, que pretende acompanhar o trabalho da mídia brasileira.

Esse é o primeiro passo para mudar essa situação investigar a imprensa, entre outros, principalmente não deixar de colocar sua opinião sobre a sua liberdade, (e não aceitar tudo) que eles vim a colocar sobre a sociedade seu irmão ou vizinho quem saber o próximo e você, não vá se corromper com essa alienação você e forte para vencer qualquer situação, pois se lembre nesse sistema só os fortes sobreviver.

\section{ANÁLISE}

Primeiramente, devemos mencionar que há muita dificuldade do produtor em utilizar adequadamente a modalidade escrita da língua portuguesa. Os desvios em nível formal, especialmente no tocante à ortografia, à acentuação, entre outros são graves.

No primeiro parágrafo, o autor faz confusão em relação às pessoas do discurso. Primeiramente, se refere à terceira pessoa, dizendo que "atualmente as pessoas Têm pedido sua liberdade atraves do sistema de comunicação". Continua da mesma forma quando usa os termos "da população" e "das pessoas humildes". Posteriormente, o produtor coloca: "uma mídia que está pronta para auto-te-condena ou te absorve ou (te fazer famoso)", utilizando a 
segunda pessoa do singular e, logo depois, insere o pronome "você" para se referir ao leitor: "bastar você querer".

Ainda no parágrafo introdutório, há um trecho que podemos considerar uma infração à MR3, já que contradiz o mundo real e pode causar problemas com relação à aceitabilidade. Isso ocorre quando o autor menciona: "uma mídia que está pronta para auto-te-condena ou te absorve ou (te fazer famoso)". Como alguém poderia querer ser condenado ou "absorvido"? Além de não ser um trecho muito claro, causa bastante estranheza.

A falta de conectores entre as orações é imensa, prejudicando ainda mais o texto em termos argumentativos.

Em suma, a falta de conhecimento sobre o assunto abordado, a desestruturação formal, o uso de lugar-comum e clichês acabam por tornar o texto fraco e sem credibilidade.

\title{
0395041-7
}

\section{Como garantir a liberdade de informação e evitar abusos nos meios de comunicação}

Os programas sensacionalistas do rádio e de programas policiais são realmente senas fortes por monstrar o lado cruel e violento das pessoais como virmos todos os dias pessoas sendo acusadas por crimes, assaltos e outros absurdos.

A comunidade de baixa renda é a sempre prejudicada, prejudicada em não ter estudo em não saber seus direito sendo vista como pessoas ignorantes, porém tendo que expor seus filhos, seus irmãos, seus amigos.

Vamos obter mais educação entre familias e entre pessoas que expoem o nosso rosto nas frente das cameras, pessoas trabalhadoras com espectiva.

Limitando criancas a ver cenas trajicas do dia a dia.

\begin{abstract}
ANÁLISE
Uma leitura global revela uma quase total desarticulação entre o texto e o tema proposto (MR4). A dificuldade do autor em se expressar de maneira satisfatória é intensa.

No primeiro parágrafo, nos deparamos com a seguinte informação: “Os programas sensacionalistas do rádio e de programas policiais são realmente senas fortes por monstrar o lado cruel e violento das pessoais". Geralmente, quando falamos em cenas, nos meios de
\end{abstract}


comunicação, estamos nos referindo a algo visual, concreto. No entanto, o autor afirma que cenas fortes são mostradas pelos programas de rádio, configurando uma espécie de infração à MR3.

Outra infração a essa mesma metarregra pode ser encontrada entre o terceiro e quarto parágrafos, em que o produtor menciona: "Vamos obter mais educação entre familias e entre pessoas que expoem o nosso rosto nas frente das cameras, pessoas trabalhadoras com espectiva. Limitando criancas a ver cenas trajicas do dia a dia". Então a solução seria limitar as crianças a verem cenas trágicas?

O texto apresenta em toda a sua extensão lacunas textuais que, mesmo complementadas pela ação interpretativa do leitor, dificultam o entendimento do texto. Revelam-se, assim, problemas com relação ao domínio de habilidades de leitura e escrita por parte do autor, além do pouco domínio da estrutura do texto escrito.

\section{4-9}

\section{Aonde estão nossos direitos}

Neste mundo em que estamos será um pouco difícil conseguirmos ter um pouco de liberdade de informação. Em certas situações não procuramos saber de nossos direitos e deveres por causa disto acontece muitas injustiças com nossos cidadões, e em certos momentos não conseguimos evitar o abuso dos meios de comunicação.

Gerálmente o que ouvimos no rádio e na televisão são pessoas humildes sendo acusadas de vários delitos, que muitas vezes eles nem cometeram. Coitados muitas vezes não sabem do seu direito, certas ocasiões por não terem condições de ir a escola ou se educar, ou por não ter interesse e aí começa o abuso dos meios de comunicação, filmando você expondo seu rosto a população, muitas vezes você é até inocente mas mesmo assim eles não querem nem saber, o que eles querem é manter o seu ibope elevado, não se preocupam em saber se estão estragando mais uma vida, de um pobre cidadão humilde, formando ali mais um marginal.

Por isso temos que nos informar dos nossos direitos e deveres, para sermos excelentes cidadões e nos defendermos dos meios de comunicações e termos liberdade para conquistar nossos objetivos.

\section{ANÁLISE}


Verificamos, nesse texto, que não há uma preocupação por parte do autor em utilizar uma linguagem mais elaborada, nem mesmo de escrever com correção, já que esse é um dos procedimentos argumentativos. Isso tudo diminui o poder de persuasão de quem fala.

A desestruturação formal não termina aí, tendo em vista que o autor nem mesmo faz a divisão paragráfica adequada, tornando seu texto um bloco enorme de ideias, muitas vezes confusas.

Termos como: "e aí começa [...]", "[...] eles não querem nem saber" e "coitados" acabam por tirar a credibilidade do texto.

No que diz respeito à metarregra da repetição, podemos citar alguns exemplos de infrações. Em: "Gerálmente o que ouvimos no rádio e na televisão são pessoas humildes sendo acusadas de vários delitos, que muitas vezes eles nem cometeram" a substituição gramatical está inadequada, tendo em vista que o pronome "eles", o qual deveria retomar "pessoas", encontra-se no gênero inadequado.

A repetição de termos, no começo do texto, poderia ter sido evitada por demonstrar falta de criatividade e se encontrarem muito próximos.

A falta de uma revisão mais criteriosa também fez com que o autor misturasse as pessoas do discurso no decorrer do texto.

Em suma, o grau de informatividade do texto é bastante baixo, revelando muitos problemas com relação às habilidades de leitura e escrita por parte do autor, bem como de seu restrito conhecimento de mundo.

\section{9-7}

Todos os dias presenciamos, seja pela televisão, ou qualquer outro meio de comunicação, cenas que constrangem e chocam, matérias em jornais e revistas sensacionalistas, que não respeitam, ao bravo povo brasileiro, a nação e até mesmo o mundo.

Os meios de comunicação deveriam, serem supervisionados por algum órgão público, que não negasse a liberdade de imprensa mas também que não permitisse que os cidadões fossem expostos ao ridículo, de terem as casas invadidas por policiais escoltando aos cinegrafistas, em busca de uma aparição na tv, no cinema entre outros.

O governo deveria criar, um órgão que supervisionasse os meios de comunicação, cujo qual se comprometeria, a não interferir na liberdade de imprensa e tentar impedir, aos abusos da imprensa para com o cidadão brasileiro. 
É incompatível para com o Brasil, com toda a sua dimensão geográfica, uma grande potência no mundo, não intervenha nos meios de comunicação assim como outros países já o fazem, e permitindo que continue ocorrendo abusos, abusos e mais abusos.

O governo deveria ser bem mais estruturado, mas por enquanto que isso não acontece, vamos tentar combater as coisas que achamos que estão erradas, até quando acabar as nossas forças.

\section{ANÁLISE}

Esse texto não apresenta dificuldades no que diz respeito à decodificação, mas contém muitas falhas.

O primeiro problema que deve ser apontado é o uso constante do requisito de repetição. Esta, desejada por demonstrar a retomada e a manutenção da mesma sequência temática, fica empobrecida pelo uso automático das mesmas palavras, sem que o autor faça uso da substituição.

O termo "meios de comunicação" é reiterado em todos os parágrafos, com exceção do último. Outros sinônimos poderiam ter sido usados.

No terceiro parágrafo, o vocábulo "imprensa" é repetido, exatamente, após escrever mais seis palavras, configurando outra infração à MR1, já que o autor poderia ter sido um pouco mais criativo: "não interferir na liberdade de imprensa e tentar impedir, aos abusos da imprensa".

O segundo e terceiro parágrafos falam praticamente da mesma informação. Desta forma, podemos perceber duas infrações: uma à metarregra da repetição (paráfrase indevida) e outra à MR2, já que não há progressão no que diz respeito à informatividade.

O quarto parágrafo, devido à falta de conectores e articulação entre as ideias, é um trecho bastante confuso que exige muita paciência do leitor.

Enfim, o uso do chavão "ao bravo povo brasileiro" da linguagem coloquial e a falta de argumentação culminam na elaboração de um texto com muitas deficiências, corroborando a falta de coesão e coerência textuais. 


\section{5-9}

Os meios de comunicação no mundo todos os dias em segunda a segunda, escutamos informações seja no radio, revista, jornais, internete ou televisão. De qualquer parte do mundo ouvimos noticias.

Falando especificamente do Brasil esses meios de comunicação de extrema emportancia para a sociedade e nossa vida cotidiana de trabalho, pesquisas e até mesmo para ficar informados. É necessário que as pessoas que tem acesso a esses tipos de informação tenha uma leitura critica seja "boa ou ruim" dependo do pondo de vista do sujeito que publicou o artigo.

Falando de televisão onde uma grande massa, da sociedade tem acesso jornais novelas programas enfantis alguns programas educadores enfin, são muitas que ajudam a ampliar o nosso conhecisnemento e preservar nossa cultura etc. Mas existem alguns tipos de programas que não beneficia socieda com por ex. Progama a tarde que fala de sexo livre abertamente, filhas que não respeitam os limites dos país, noticiário e propaganda que envade a privacidade da vida a leia das pessoas para uso da midia. Enfim são muitos os tipos de noticias e informações erradas e muitas vezes não são verdadeiras que usam para reduzir as pessoas.

Devemos usar as informações e fazer com ética respeitando que assitem o ler seja de qual forma for usada, contado que seja de enteresse e para o bom uso da sociedade tendo sensibilidade de usar adquadamente evitando abuso e preservando a liberdade das sociedades.

\section{ANÁLISE}

A primeira característica desse texto que deve ser assinalada é a extrema dificuldade do autor em utilizar a modalidade escrita. Não há articulação entre as ideias e orações (MR4).

O sentido de algumas afirmações demanda, do leitor, um exercício de boa vontade, pois além de não trazerem qualquer contribuição ao texto, revelam um elevado grau de desarticulação lógica e semântica. A exemplo disso, temos o primeiro parágrafo: "Os meios de comunicação no mundo todos os dias em segunda a segunda, escutamos informações seja no radio, revista, jornais, internete ou televisão. De qualquer parte do mundo ouvimos noticias".

Outro exemplo pode ser verificado no primeiro período do segundo parágrafo: "Falando especificamente do Brasil esses meios de comunicação de extrema emportancia 
para a sociedade e nossa vida cotidiana de trabalho, pesquisas e até mesmo para ficar informados".

A questão da liberdade de expressão não é citada nenhuma vez, revelando, mais uma vez, uma infração à MR4, já que texto e proposta não se conectam.

As lacunas deixadas pelo autor são imensas. Assim, a falta de clareza contribui, demasiadamente, para a perda do poder de persuasão do produtor.

Enfim, estamos diante de um texto que revela tanto problemas com relação ao restrito conhecimento de mundo do autor, quanto à falta de capacidade de estruturação formal de seu texto.

\section{8-0}

Os meios de comunicação existentes são muito importantes porque é atravéz deles que ficamos informados sobre diferentes assuntos.

Porém muitas vezes alguns profissionais esquecem o seu limite e os utrapaçam, certo que eles tem por direito no artigo $5^{\circ}$ na constituição federal de 1988.

IX - é livre a exprssão da atividade intelectual artística ciéntífica e de comunicação, independente de censura ou licença, e isso não da o direito de mentir, envadir, ou até mesmo degrenir a imagem de pessoas como tem alguns jornalista, repórter por meio da mídia, até por que a outra parágrafo do mesmo artigo que diz:

X - São invioláveis a intimidade, a vida privada, a honra e a imagem das pessoas, assegurando a indenização pelo dano material ou moral decorrente de sua violação.

Sendo assim os comunicadores deviam analizar muito bem antes de apresentar para os telespectadores uma notícia.

Antes de qualquer coisa responsaveis devem procura ver quem esta fazendo seu trabalho corretamente, atravez de pesquisas e assim poder tomar providencia sobre aqueles que usa o meio de comunicação para passa informações falsas.

\footnotetext{
ANÁLISE

Primeiramente, devemos mencionar a extrema dificuldade do autor em utilizar, aceitavelmente, a modalidade escrita. Não há articulação entre as ideias e orações (MR4).
} 
O primeiro parágrafo não acrescenta em nada, já que o grau de informatividade é bastante baixo, sendo baseado, exclusivamente, no senso comum.

A desestruturação formal pode ser claramente notada no segundo parágrafo, em que, apesar de o autor iniciar satisfatoriamente com uma conjunção adversativa ("porém), emprega palavras que não são, posteriormente, explicadas, causando dúvidas no receptor: "Porém muitas vezes alguns profissionais esquecem o seu limite e os utrapaçam, certo que eles tem por direito no artigo $5^{\circ}$ na constituição federal de 1988.". O leitor fica sem saber a quais profissionais o autor estaria se referindo.

Nesse mesmo exemplo, podemos notar que a falta de pontuação e de conectores inviabiliza a leitura, já que o autor a torna bastante confusa.

Trechos da Constituição Federal são mencionados na produção, mas, ao invés de configurar intertextualidade, compromete ainda mais a argumentatividade do texto, tendo em vista a desorganização de ideias do autor.

Em suma, muitos problemas relacionados às habilidades de leitura e escrita por parte do autor são verificáveis no texto, corroborando a falta de coesão e coerência textuais.

\title{
0395105-5
}

\section{Como garantir a liberdade de enformação e evitar abuso nos meios de comunicação?}

$\mathrm{Na}$ verdade existe, vários meios como evitar o abuso no meio de campo.

Se todos nós tivessemos plena consciencia e devidisemo a informação que ocorre no dia a dia e mundo seria melhor, não adianta só.

Nós temos que ler, procurar mais informações para que e amanhã nós não ficarmos de mao abanando. A vida lá fora esta bastante difícil, nos não só para quem procura informação e de quem tem também.

Sei que tudo passa mas nem tudo frere o quanto você e eu sofremos.

Não sou egoísta mais quero ser feliz.

\begin{abstract}
ANÁLISE
O texto surpreende, mesmo antes de uma análise mais aprofundada, pela extrema dificuldade do aluno em utilizar, aceitavelmente, a modalidade escrita da língua portuguesa e pela sua incapacidade de organizar suas ideias de maneira satisfatória.
\end{abstract}


O primeiro parágrafo nos impressiona pela total desarticulação entre tema e texto: " $\mathrm{Na}$ verdade existe, vários meios como evitar o abuso no meio de campo.".

$\mathrm{O}$ segundo parágrafo, além de não estabelecer relação com o primeiro (MR1), não consegue transmitir, de maneira eficiente, nenhuma informação: "Se todos nós tivessemos plena consciencia e devidisemo a informação que ocorre no dia a dia e mundo seria melhor, não adianta só.”. O leitor logo se pergunta: consciência de quê? Além disso, não se sabe o que o emissor quer dizer quando menciona que "devemos dividir as informações para um mundo melhor".

Os dois últimos parágrafos infringem, mais fortemente, a MR4, por não estabelecerem relação alguma com o desenvolvimento do texto: "Sei que tudo passa mas nem tudo frere o quanto você e eu sofremos.”; “Não sou egoísta mais quero ser feliz.”.

Em suma, faltam, ao texto, praticamente todos os elementos mínimos para o desenvolvimento de uma produção aceitável. A fuga quase que total ao tema, associada à falta de conhecimento de mundo e desfamiliarização com a escrita, culminou na elaboração de um texto confuso e sem informatividade.

\section{9-7}

É muito comum no nosso cotidiano presenciarmos a falta de respeito por parte da imprença onde em qualquer lugar se encontra, basta que aconteça um simples fato. É a corrida pela notícia, pela informação é sempre assim um querendo chegar primeiro que o outro e quando chega não interessa onde estão só querem intrevistar, fotografar e tudo isso sem pedir permição.

E assim vai nascendo notícias da censura humana e geralmente o pessoal da periferia onde o pessoal da periferia onde o respeito não tem máscara, a humilhação nua e crua é a corrida pela comunicação e informação imediata que acompanha os passos da globalização. Só podemos nos manter informados sem manipulação das pessoas, sem abuso, sem se desfazer do outro basta saber uma só coisa, que todos nós somos iguais, somos humanos e queremos notícia de qualidade. 
Globalmente, podemos dizer que o nível de textualidade resultante desta produção é baixíssimo.

Além da desestruturação formal, a falta de conhecimento sobre o assunto prejudica sobremaneira a elaboração do texto.

No início do primeiro parágrafo, o autor coloca que: "é muito comum no nosso cotidiano presenciarmos a falta de respeito por parte da imprença [...]”, mas não nos informa que tipo de desrespeito é esse; nem quem a imprensa desrespeita. Essa lacuna deixada pelo autor configura uma espécie de infração à MR2, já que o autor não desenvolve a informação.

Problemas com relação ao aspecto lógico-semântico também podem ser verificados. No momento em que o produtor menciona: "E assim vai nascendo notícias da censura humana", fica difícil para o leitor compreender o que o autor quer dizer. O mesmo ocorre em “[...] onde o respeito não tem máscara $[\ldots] "$.

Uma generalização, procedente da falta de atenção e revisão do texto, também contribui para o descrédito da produção: "Só podemos nos manter informados sem manipulação das pessoas, sem abuso, sem se desfazer do outro basta saber uma só coisa, que todos nós somos iguais, somos humanos e queremos notícia de qualidade.". Será que os abusos e a manipulação já não ocorrem? E mesmo diante desse fato, será que não temos acesso à informação? Vemos, pois, uma infração à MR3.

Em suma, o autor necessita expor um grau de informatividade mais elevado ao texto. Além disso, ele precisa ter um conhecimento mais aprofundado da estrutura de um texto dissertativo-argumentativo.

\section{6-7}

Lutando pelos nossos direitos se informando de como devemos agir a esse tipo de abuso.

Não devemos sofrer calados, sentirmos que estamos sendo coagidos devemos tomar alguma atitude.

Todos nós devemos lutar pela nossa liberdade de comunicação e de informação.

As empresas de comunicação não respeita a população e muitos acusam os jornalistas, sendo que a verdadeira culpada e as empresas.

Somos humilhados, perante a toda sociedade, que tapa os olhos diante desses abusos. 
A mídia esponhe um massacre do final de semana mas esconde um roubo feito por políticos.

Não é dessa comunicação que nós povo brasileiro estamos precisando, precisamos sim de ser informados de cada acontecimento, mas conservando pessoas que não merecem esse tipo de tratamento.

\footnotetext{
ANÁLISE

Inicialmente, devemos dizer que o autor nem mesmo tem conhecimento da estrutura de um texto dissertativo. A desfamiliarização com a produção textual é revelada através do primeiro parágrafo, em que o autor parece responder ao questionamento feito na proposta (tema): "Lutando pelos nossos direitos se informando de como devemos agir a esse tipo de abuso.".

Os primeiros parágrafos, ao invés de nos informar sobre o tema, inserem, de forma direta, posições que deveriam fazer parte da conclusão:

"Não devemos sofrer calados, sentirmos que estamos sendo coagidos devemos tomar alguma atitude.".

“Todos nós devemos lutar pela nossa liberdade de comunicação e de informação.”.

"As empresas de comunicação não respeita a população e muitos acusam os jornalistas, sendo que a verdadeira culpada e as empresas.”.

Uma infração à MR2 pode ser verificada no quarto parágrafo, em que o emissor diz que as empresas de comunicação não respeitam a população, mas não menciona de que forma.

O texto não contém articulação entre os parágrafos, mormente do primeiro ao quarto. Não há relação entre as ideias.

O último parágrafo, além de não ser conclusivo, tendo em vista que nada propõe, deixa uma dúvida no leitor, pois, quando afirma: "Não é dessa comunicação que nós povo brasileiro estamos precisando, precisamos sim de ser informados de cada acontecimento, mas conservando pessoas que não merecem esse tipo de tratamento.", não sabemos que tipo de tratamento é esse, já que não temos o antecedente.

Enfim, através da leitura, podemos inferir que não há conhecimento de mundo suficiente para o aluno produzir um texto argumentativo de qualidade sobre o tema proposto.
} 


\section{8-0}

\section{Como garantir liberdade de informação $E$ evitar abusos nos meios de comunicação}

A liberdade é um fato que se dispõem de muitos meios de comunicação ou seja é abordado como forma de expressaõ.

Como sabemos a liberdade de informação é bem relatada para todos, mais com uma distorção. por que no meio social de baixa renda ela não é bem exelsecida por fator de for maior ou seja eles não querem que as pessoas de baixa renda se dispoem de informações para que depois não venham votar-se contra eles que são a maior massa social de um bom poder iconomico.

A melhor maneira de que a informação seja bem exclarecida é que os meios de comunicação não sofra abuso e que os grupos de maior poder iconomico financeiro não venham intervir no nosso meio relatando absurdos ou distorcendo os assuntos que é de maior interesse para a população, que hoje em dia é bem desinformada, ou seja eles não sabem bem ao seus direitos por que os maiores culpados disso é os politicos que possuem uma propaganda enganosa para a população.

Peço que essa realidade venha muda é preciso que tenhamos um bom censu e que daqui pra frente não deixamos de obter uma melhor informação mesmo que eles tentem esconder.

\footnotetext{
ANÁLISE

Verificamos, nessa redação, extrema dificuldade do autor em utilizar aceitavelmente a modalidade escrita da língua portuguesa. Os desvios em nível formal são graves e, além da desestruturação formal, há problemas no aspecto lógico-semântico.

O ajuntamento de palavras, no primeiro parágrafo, não garante um significado concreto para o texto: "A liberdade é um fato que se dispõem de muitos meios de comunicação ou seja é abordado como forma de expressão".

O segundo parágrafo não progride em termos informativos, configurando, mais uma vez, a ilogicidade das orações: "Como sabemos a liberdade de informação é bem relatada para todos".

Problemas com o uso indevido do recurso da MR1 também são frequentes. No segundo parágrafo, o autor menciona que "[...] eles não querem que as pessoas de baixa
} 
renda se dispoem de informações", denotando pronominalização inadequada, neste caso, por não haver antecedente: eles quem?

No mesmo trecho, embora se possa pressupor o referente, o pronome "eles" causa ambiguidade, já que temos dois referentes (as pessoas de baixa renda e eles): "eles não querem que as pessoas de baixa renda se dispoem de informações para que depois não venham votar-se contra eles que são a maior massa social de um bom poder iconomico".

A falta de clareza do assunto abordado fica evidente no trecho: "A melhor maneira de que a informação seja bem exclarecida é que os meios de comunicação não sofra abuso e que os grupos de maior poder iconomico financeiro não venham intervir no nosso meio [...]", pois os meios de comunicação proporcionam os abusos e não os sofrem.

O último parágrafo é bastante fraco em termos argumentativos, e ineficaz em relação ao seu real objetivo.

\section{8-8}

Como garantir a liberdade de informação e evitar abusos no meio de comunicação.

O meio de comunicação está hoje em dia amplo e caçador á variados tipos de acontecimentos sendo eles até mesmo banalizados, tornando-se o ramo mais competitivo, e escasso para produções de imagens culturais e intelectuais.

Hoje á mídia está voltada principalmente para a miséria alheia, de forma invasiva e desonesta, causada simplesmente por uma questão de audiências, causa que á principal utilizava-se esse tipo de informação, somente para alertar e beneficiar, uns aos outros; E raramente cremos isso hoje em dia.

Estamos diante de "picuinhas" de informações e por vez ela já tem uma liberdade em nossas vidas, pois é uma das formas de comunicações que já não podemos viver sem elas, más contudo é não permitir, imagens, imformações e materialização de vidas privadas que não se diz respeito ao mundo e também não se submetendo a participar de meios de comunicação passando-lhe por uma força; pois isso é o que também transgridem a ordem e os bons costumes de uma sociedade carente, pois por serem leigas não sabem cobrar de seus direitos autorais. E uma boa parte da sociedade sabendo do que não deve ser feito e cobrando seus direitos assim evitaremos os abusos no meio da comunicação. 
Foi possível verificar, primeiramente, que o restrito conhecimento de mundo do autor interferiu de forma marcante na elaboração do texto, visto que a dificuldade argumentativa, associada à desorganização de ideias, culminou na construção de parágrafos desconexos que expõem pensamentos contraditórios, corroborando a falta de coesão e coerência do texto.

As dificuldades em relação à estruturação do texto escrito são diversas. $\mathrm{O}$ uso impensado e inadequado de vocábulos, no decorrer da produção, acaba por tornar o texto ainda mais confuso. Além disso, palavras com extensão muito ampla de significado muitas vezes não são previamente definidas. A exemplo disso temos o primeiro parágrafo, em que o autor menciona: "O meio de comunicação está hoje em dia amplo", mas não nos explica o sentido de "amplo". Logo em seguida, ele menciona que o meio de comunicação está "caçador a variados tipos de acontecimentos", sendo que, para essa situação, outro vocábulo seria mais adequado.

Uma infração à MR3 pode ser verificada no final do primeiro parágrafo: "tornando-se o ramo mais competitivo, e escasso para produções de imagens culturais e intelectuais", pois, se é competitivo, como pode ser escasso?

Dificilmente o leitor conseguirá decifrar a informação que o autor quis transmitir em:

Hoje á mídia está voltada principalmente para a miséria alheia, de forma invasiva e desonesta, causada simplesmente por uma questão de audiências, causa que á principal utilizava-se esse tipo de informação, somente para alertar e beneficiar, uns aos outros; E raramente cremos isso hoje em dia.

A falta de conectores e a desarticulação das ideias do terceiro parágrafo são alarmantes, por isso, nota-se, claramente, que o texto infringe todas as metarregras de Charolles, não proporcionando, desta forma, coesão e coerência ao texto.

\section{9-8}

\section{Violação de imagem}

Como assegurar a livre imagem e acabar com a exploração nos meios de noticias, pois não é respeitado os direitos privados, além do mais são gravado sem suas autorizações e subjungado a merce do seus propósito. 
Essas gravações feita por qualquer meio de comunicação interver nas nossas vidas como se fosse um órgão autoritário, eles gravam aquelos que passa somente ser benéfico a vós, não querem saber se podem mostrar suas necessidade e os teus problemas.

As principais notícias são aquelas que aparecem urgente, mostrando uma perseguição entre policiais e bandidos numa favela, os reportes que acompanham, filmam tudo e algo mais que não pode ser filmado, como, as pessoas incluindo crianças e até o interior de uma casa, que so podem mostrar com autorização.

É importante que os nossos governantes tomem certas atitude contra esses maus profissionais que usam da ingenuidade das pessoas para ganhar audiencias, edocando-os suas angústias a população.

\section{ANÁLISE}

O autor possui dificuldade em utilizar a norma culta, apresentando sérias falhas no que compete à estruturação formal do texto, tais como: ortografia, concordância verbal/nominal, acentuação, pontuação. Os desvios são tantos que comprometem até sua compreensão, pois em muitas vezes o leitor percebe-se em meio a sequências ininteligíveis, como nos trechos: “[...] edocando-os suas angústias a população.”, do quarto parágrafo e “[...] eles gravam aquelos que passa somente ser benéfico a vós [...]”, do segundo parágrafo.

O redator não apresenta as ideias de maneira clara e peca pela falta de uso de recursos coesivos. A redação é muito carente de organização, necessitando de adequações à MR4 (articulação).

$\mathrm{O}$ autor se prende muito aos exageros cometidos pela mídia e não discorre a respeito da liberdade de informação, que também deve ser abordada no desenvolvimento do texto. Fato que pode ser constatado, também, no título que dá nome à redação "Violação de imagem”, o qual já conduz o leitor ao encontro de uma argumentação restritiva por parte do escritor. Por isso, o autor foge parcialmente do tema ao não contemplá-lo em sua totalidade.

Os argumentos apresentados são desconexos e redundantes, o que demonstra a falta de conhecimento do autor sobre a temática, uma vez que este se apega somente às informações trazidas pelos textos-base que estão na prova. Não faz acréscimos semânticos, não soma novas ideias, não faz inferências ao que já foi informado: no primeiro parágrafo “[...] são gravado sem suas autorizações”; no segundo parágrafo “[...] não querem saber se podem mostrar [...]” e no terceiro parágrafo "[...] que so podem mostrar com autorização.” 
Essa análise mostra que o texto distancia-se do que consta na MR2 (progressão) e do conceito de informatividade postulado por Beaugrand \& Dressler.

Em vários momentos o redator efetua a retomada de termos que não apresentou anteriormente ao leitor, como pode ser verificado no primeiro parágrafo: "[...] além do mais são gravado sem suas autorizações e subjungado a merce do seus propósito". Fica muito vaga essa proposição, uma vez que não se sabe a quem os pronomes possessivos se referem. Assim, nota-se discordância da MR1 (continuidade), pois é preciso que se faça a indicação do referente antes de se efetuar a substituição.

No último parágrafo, que deveria expor uma conclusão, o autor não apresenta ideias próprias, apenas reproduz o senso comum, ao afirmar que " $E$ importante que os nossos governantes tomem certas atitude contra esses maus profissionais”. Não há posicionamento crítico por parte do redator nem a tentativa de criar uma solução ao problema, uma vez que não indica quais atitudes deveriam ser colocadas em prática.

Em síntese, há a necessidade de reestruturação do texto e adequação a todas as metarregras propostas por Charolles.

\section{8-0}

Como garantir a liberdade de informação e evitar abusos no meio de comunicação

No mundo de hoje é difícil não ter abusos no meios de comunicação.

Os jornalistas não cumprim de maneira nenhuma a lei da Constituição Federal de 1988 que diz:

- São inviolaveis a intimidade, a vida privada, a honra e a imagem das pessoas, estão fazendo exatamente o contrario envadem as casas com o intuito de fazer uma reportagem e derrepente quando percebemos já estamos sofrendo o abuso da comunicação.

Há alguns anos atrás um desses abusos causou a morte de duas pessoas, e deixou aproximadamente três feridos na Inglaterra.

Acredito que podemos grantir uma liberdade de imformação sem causar tantos problemas. Poderiamos ter uma espécie de grupos que fiscalizase a imprensa mundial.

Normalmente os abusos da comunicação são sofridos por pessoas de baixa renda, eles tem suas casas reviradas, e suas vidas expostas ao mundo.

Futuramente esses problemas podem ser solucionado com a colaboração de todos e em especial a dos jornalistas, teram a privacidade de varios, mas não querem perder a sua. 


\section{ANÁLISE}

O autor desconhece a estrutura dissertativa, pois desenvolve a redação sem organização, não possuindo delimitação, articulação (MR4) nem continuidade (MR1) entre as partes integrantes: introdução, desenvolvimento e conclusão. Desconhece, também, a distinção entre o que é título e o que é tema.

É visível a dificuldade que o redator possui com o código escrito, corroborada pelos desvios de estruturação formal da língua: ortografia, acentuação, pontuação, concordância verbal.

A linguagem utilizada é repleta de pessoalidade, conforme os trechos: no primeiro parágrafo: "[...] quando percebemos já estamos sofrendo o abuso da comunicação" e no segundo parágrafo: "Acredito que podemos grantir uma liberdade de imformação [...] Poderiamos ter [...].”.

A falta de clareza é consequência das lacunas causadas pela ausência de conectores, o que prejudica a coerência do texto (MR4-articulação).

O primeiro parágrafo é composto por apenas uma linha que é insuficiente para realizar a apresentação adequada do tema, além disso, há o uso da expressão clicherizada "no mundo de hoje”, o que denuncia a falta de criatividade do autor ao iniciar sua redação.

Os parágrafos são muito curtos e em grande número, sete no total, o que deixa a argumentação comprometida, uma vez que não é possível desenvolvê-la com mais profundidade.

Nos segundo e terceiro parágrafos, o autor se apropria de trechos da Constituição Federal, tentando efetuar um paralelo entre o que é direito e o que realmente acontece. Percebe-se, nesse momento, que há intertextualidade, um dos sete fatores de textualidade propostos por Beaugrand \& Dressler. No entanto, não é realizada com propriedade, pois o autor a faz de forma confusa ao não delimitar a citação e encaixá-la ao restante do texto.

No quarto parágrafo, o autor exemplifica uma situação em que ocorreu abuso da imprensa, manifestando traços constituintes da MR2 (progressão), tentando expor informações novas a respeito do tema tratado. Contudo, não se mostra eficiente por deixar de fornecer detalhes, não informando quando aconteceu e nem os motivos da repercussão. Apenas diz que foi "há alguns anos atrás na Inglaterra". $O$ exemplo deveria servir para dar mais força à argumentação, pois o autor teria como corroborar os malefícios dos abusos da 
imprensa. No entanto, o que acontece é que a proposição é apenas colocada no texto, não sendo desenvolvida. Por isso, esse fragmento necessita de adequação à MR4 (articulação).

O último parágrafo mostra-se desconexo, não apresentando embasamento concreto e com um desfecho praticamente incompreensível: "Futuramente esses problemas podem ser solucionado com a colaboração de todos e em especial a dos jornalistas, teram a privacidade de varios, mas não querem perder a sua.”.

\section{2-8}

Estima-se que todos gostam de programas esportivos, novelas, telejornais, programs infantis. A televisão realmente tem sua importância nos lares não só do Brasil, como do mundo inteiro.

Nos últimos anos temos percebido que os programas de televisão têm estendido reportagens pouco saudáveis para determinado tipo de telespectador.

Além dos crimes que vemos acontecer no Brasil, vemos também as guerras que estão acontecendo frequentemente em outros países. Assaltos, seqüestros, terrorismo.

A liberdade de expressão e democracia é bem defendida, a liberdade de informação se mantém presente em todos os meios de comunicação. Mas nenhum desmerecem o poder da televisão. Por isso várias emissoras abusam do poder para aumentar o ibope.

Deveria haver mais especulação por parte dos órgãos responsáveis. Certas coisas que vemos ou ouvimos deveriam ser um pouco evitadas, ou apresentadas de forma que não chocasse o público.

\section{ANÁLISE}

O texto não apresenta grandes desvios da estrutura formal da língua, não criando obstáculos para sua decodificação, apesar de possuir falhas de concordância verbal e nominal.

Há o uso de um tom pessoal no desenvolvimento do texto, conforme os trechos: no segundo parágrafo: "temos percebido"; no terceiro parágrafo: "Além dos crimes que vemos acontecer no Brasil”; e no quinto parágrafo: "Certas coisas que vemos ou ouvimos [...]".

Não foi colocado título na redação, deixando o autor de aproveitar a oportunidade de chamar a atenção de seu leitor antes de iniciar o texto propriamente dito. 
O emissor apega-se muito ao que as emissoras estão exibindo, não discorrendo necessariamente sobre a proposta trazida pelo tema. A argumentação é redigida de modo simplista, não fazendo nenhum aprofundamento de forma crítica e concreta. Há repetição de vocábulos (programas, televisão), que poderiam ser retomados se utilizados os recursos propostos pela MR1.

Em alguns momentos o emissor realiza uma boa articulação entre as sequências textuais: "Além dos crimes que vemos acontecer no Brasil, vemos também as guerras que estão acontecendo freqüentemente em outros países.".

Os três primeiros parágrafos são desenvolvidos com certa coerência, mas no quarto e quinto parágrafos há sequências desconexas, que comprometem o entendimento da argumentação realizada pelo redator, como nos trechos: "A liberdade de expressão $e$ democracia é bem defendida, a liberdade de informação se mantém presente em todos os meios de comunicação. Mas nenhum desmerecem o poder da televisão." e "Deveria haver mais especulação por parte dos órgãos responsáveis. Certas coisas que vemos ou ouvimos deveriam ser um pouco evitadas, ou apresentadas de forma que não chocasse o público."

Ao utilizar o vocábulo "especulação", provavelmente o redator deve ter se confundido e colocado essa palavra no lugar de "fiscalização", que possui significado totalmente diferente do termo utilizado no texto e que se encaixaria melhor ao que se está reivindicando.

Um dos pontos preocupantes dessa redação encontra-se na conclusão do texto, pelo uso incorreto do advérbio "pouco”, uma vez que, ao colocá-lo na sentença, o autor altera todo o sentido do período, provocando incoerência, isto é, colocando-se contra o que orienta a MR3 (não-contradição).

\section{3-3}

Como garantir a liberdade de informação e evitar abusos no meio de comunicação "Respeito ao cidadão"

Acredito que a mídia tem o seu lado positivo; que é de trazer informações para o público, e também tem seus aspectos negativos; que é ir para um local inadequado.

A imprensa quando ela tem que aparecer no local em devido horário não aparece, agora quando eles ouvem um comentário que um pai de família roubou algo no mercado para 
sustentar os filhos logo aparecem, mas quando tem precisão, de aparecer, que um bandido matou ou furtou, às vezes só vem aparecer nas rádios, jornais e TVs após dois dias.

Nos rádios e jornais não passam mais nada que as pessoas possam ficar alegre, só falam de furto, morte, miséria... Mas com o mundo que vivemos hoje não podemos esperar mais nada.

Pois a mídia tem que saber aonde vai fazer sua comunição de seua filmagem, porque acaba atingindo um cidadão que não tem nada haver.

$\mathrm{Eu}$ acredito que a mídia tem que fazer a sua parte, mas de modo que o respeite.

\section{ANÁLISE}

Com base na leitura realizada, é possível afirmar que quem escreveu a redação desconhece a estrutura e características dissertativas. É presente a fuga parcial ao tema, uma vez que a proposta temática não é contemplada em sua totalidade, fato que revela infração à MR4 (articulação). O autor aborda os abusos da mídia e não argumenta absolutamente nada sobre como garantir a liberdade de informação.

A argumentação apresenta-se de maneira desorganizada, falta articulação entre as ideias expostas (MR4), revelada pela carência de recursos coesivos. A argumentatividade fica comprometida, visto que as sequências são desconexas e apresentam comentários que não contribuem para o desenvolvimento de um texto crítico e consciente, o que pode ser constatado no terceiro parágrafo: "Nos rádios e jornais não passam mais nada que as pessoas possam ficar alegre, só falam de furto, morte, miséria [...] Mas com o mundo que vivemos hoje não podemos esperar mais nada.”.

A falta de conhecimento sobre o tema proposto culmina na redundância, havendo exaustiva repetição de ideias (e palavras), como pode ser notado no segundo parágrafo:
A imprensa quando ela tem que aparecer no local em devido horário não aparece, agora quando eles ouvem um comentário que um pai de família roubou algo no mercado para sustentar os filhos logo aparecem, mas quando tem precisão, de aparecer, que um bandido matou ou furtou, às vezes só vem aparecer nas rádios, jornais e TVs após dois dias.

Como pode-se observar nesse parágrafo há infrações às MR1 (continuidade), MR2 (progressão) e MR4 (articulação).

É notória a dificuldade que o emissor possui em relação à língua escrita, cometendo falhas de cunho estrutural e também lógico-semânticas, as quais são ainda mais graves. O 
vocabulário reduzido acaba favorecendo o aparecimento de repetições lexicais, como o verbo aparecer, por exemplo.

Em alguns momentos, o leitor percebe-se em meio a trechos desconexos, sequências confusas que não contribuem para a argumentatividade, não havendo atitude persuasiva por parte do autor.

Tomemos como exemplo o primeiro parágrafo: "Acredito que a mídia tem o seu lado positivo; que é de trazer informações para o público, e também tem seus aspectos negativos; que é ir para um local inadequado." O que seria este local inadequado? O que será que o emissor quis dizer? A falta de clareza e de fundamentação não possibilita o entendimento da mensagem, a tentativa de uso da MR2 (progressão) acabou por deixar o texto confuso e com lacunas, as quais o receptor não consegue fazer inferências para preenchê-las. É possível afirmar, também, que há discordância à MR4 (articulação) por apresentar uma ideia que nada se relaciona com a proposta temática.

A pronominalização é utilizada, mas seu uso inadequado deixa a sequência redundante, como pode ser observado no $2^{\circ}$ parágrafo: “A imprensa quando ela tem que aparecer no local em devido horário não aparece." Desse modo, a utilização da MR1 (continuidade) não contribuiu para a clareza do texto.

A conclusão apresenta-se em um parágrafo muito curto, no qual não há argumentação. Observa-se apenas generalidade no que o autor sugere para acabar com aos abusos na mídia, não havendo criticidade. $O$ emissor não se posiciona na defesa de sua opinião, apenas reproduz uma ideia muito vaga de significação. Com base nisso, a informatividade (Beaugrand \& Dressler) desse texto fica totalmente comprometida pelas frequentes repetições de palavras e ideias, como também, pela falta de posicionamento crítico do autor.

\section{3-8}

\section{Como garantir a liberdade de enformação e evitar abusos no meio de comunicação}

Vivemos em um país em que a enformação e muito e muito enportante tanto para a noça formação culturao: para o noso conhecimento emgeral. É preciso que estejamos pôr acontecimento nu Brasil e nu mundo as pessoas precisão dessas comunicação.

As pessoas não pode ficar se saber a realidade o nosso país.

Aver poriso devemos asutar que pessoas resposavel vea prejudicar pessoas como noticia maldosas. 
Deve criar leis que passe a tratar desas coisa que seje leis regorosas. Não e preciso que estas percão os seus enpregos mas que tenhão ao seu trabalho respeitando o direito de todos.

O seu papel e trazer as noticias não aproveitando do seu poder para criar elementos qe possa destruir a vida de outra pessoa.

\begin{abstract}
ANÁLISE
O texto surpreende, mesmo antes de uma análise mais aprofundada, pela extrema dificuldade do emissor em utilizar aceitavelmente a modalidade escrita da língua portuguesa. Os desvios em nível formal, especialmente no tocante à ortografia, à acentuação gráfica e à pontuação são graves. Além da desestruturação formal, há problemas no aspecto lógicosemântico, sendo possível localizar infrações às quatro metarregras ao longo do texto.

É importante ressaltar que os desvios da estrutura formal da língua e o não-uso da norma culta, por serem recorrentes em todo o texto, comprometem o entendimento da redação, formando, em muitos momentos, parágrafos ininteligíveis, como pode ser observado no terceiro parágrafo: "Aver poriso devemos asutar que pessoas resposavel vea prejudicar pessoas como noticia maldosas”.

$\mathrm{O}$ autor desconhece a estrutura dissertativa, pois desenvolve a redação sem organização, não possuindo delimitação, articulação (MR4), nem continuidade (MR1) entre as partes integrantes: introdução, desenvolvimento e conclusão. Desconhece, também, a distinção entre o que é título e o que é tema.

O primeiro parágrafo é constituído de sequências desconexas, pois o emissor utiliza a MR1 de forma equivocada, usando primeiramente o hiperônimo "país" para só depois utilizar o hipônimo "Brasil", situação que comprometeu a clareza, não favorecendo a coerência textual.

Ainda no primeiro parágrafo, há o trecho "[...] as pessoas precisão dessas comunicação.”, em que se percebe a utilização do recurso de retomada textual, sem o autor explicitar ao que está se referindo. É inevitável a pergunta: quais tipos/meios de comunicação? Essa situação seria aceitável desde que tivesse sido explicitado a quem "dessas comunicação" está substituindo. O referente deveria ter sido apresentado ao leitor, para depois, de forma anafórica, ser utilizada a expressão em seu lugar. Verifica-se, desse modo, discordância à MR1 (continuidade), no que diz respeito à substituição gramatical. A mesma infração ocorre no quarto e quinto parágrafos com os pronomes "seus" e "seu".
\end{abstract}


O segundo parágrafo é formado por apenas uma linha: “As pessoas não pode ficar se saber a realidade o nosso país.” Nota-se um comentário vazio de sentido, uma vez que o autor não informa qual seria essa realidade, nem a caracteriza para o leitor, distanciando-se, assim, da MR2 (progressão).

O texto é enxuto e apresenta muitas repetições lexicais, as quais denunciam o vocabulário restrito do autor. A palavra "pessoa(s)" é repetida várias vezes, deixando o emissor de usar o recurso da substituição (MR1-continuidade).

Não foi realizada a conclusão, pois o que se tem no último parágrafo é um comentário que não demonstra posicionamento crítico do autor, que termina o texto em duas linhas desprovidas de qualquer tipo de fundamentação e lógica.

\section{7-0}

\section{Como garantir a liberdade de informação e evitar abusos no meio de comunicação}

Garantindo com liberdade a maneira de pensar, e respeitando a opinião de cada um, no meio da comunicação assim podemos ter informações sobre os abusos causados nas empresas nos jornalismo, podemos fiscalizar cada um que trabalhar até presente assim podemos ter mais liberdade para trabalhar. Infelismente ainda existem gente que não consegue seguir o padrão da empresa, mesmo quando são ameaçados. Assim, dis respeitando as ordens a seguir nossa liberdade somos nós que criamos e tentamos nós enformar de tudo que está acontecendo em nosso meio so assim podemos ser útil dentro de uma empresa de qualquer porte, desenvolvendo nosso trabalho com competência e habilidade e pricipalmente com amor em tudo que fizermos. Por isso e direito nosso garantir nossa liberdade de informações, e assim evitando abusos nos meios de comunicação.

\section{ANÁLISE}

O aspecto visual da redação já demonstra a total falta de conhecimento do autor da estrutura dissertativa, visto que não há paragrafação. O que se vê é um bloco contínuo de palavras. O produtor do texto, também, não reconhece o tema como proposta para o desenvolvimento de seu texto e sim, como uma simples pergunta, a qual faz a tentativa de responder. Isso pode ser verificado no início do primeiro parágrafo: “Garantindo com liberdade a maneira de pensar, e respeitando a opinião de cada um [...]”. Contudo, não é 
explicado ao leitor de que maneira isso pode ser feito e quem deve se responsabilizar ao ser colocada essa proposta em prática.

A falta de pontuação, além de outros fatores, prejudica o entendimento do que o emissor tenta dizer. A carência de pausas na leitura, vírgula e ponto final criam períodos muito longos, quase incompreensíveis. O texto inteiro apresenta falta de organização, possuindo carência de recursos coesivos e comprometimento em sua linearidade e coerência.

É preciso enfatizar que houve confusão por parte do emissor sobre o que é tema e o que é título, uma vez que repete-se a proposta no campo para o qual destina-se o título da redação. Houve fuga parcial da proposta temática, fato que prejudicou a argumentatividade, pois o redator não contemplou a proposta em sua totalidade, o que nos possibilita afirmar que há discordância com a MR4 (articulação).

Em vários momentos, percebe-se que o autor inicia uma ideia e não a conclui antes de iniciar outra informação, o que, mais uma vez, mostra a falta de conectores (MR4-articulação) na constituição do texto.

Nota-se, também, que não há uma continuidade adequada (MR1). As palavras são repetidas e a dissertação fica empobrecida de recursos de retomada textual, tais como: sinônimos, pronomes ou advérbios. Tudo isso mostra o léxico limitado do autor, o qual também não possui um conhecimento aprofundado do tema, fato confirmado pela superficialidade dos argumentos apresentados.

Sobre a informatividade (Beaugrand \& Dressler - fatores da textualidade), o emissor não expõe nenhuma informação relevante, deixando a desejar nesse quesito. Apenas reproduz ideias muito genéricas, provenientes do senso comum, portanto, sem fundamentação.

Essa redação é problemática no que diz respeito à coesão e à coerência, necessitando de reestruturação e reescrita. Assim, de uma forma geral, foram infringidas todas as metarregras postuladas por Charolles.

\section{9-1}

\section{As falhas da comunicação}

É comum em meio a comunicação o aparecimento de boatos, fofocas e a invasão de privacidade. Novelas que retratam histórias que acabam interferindo na mentalidade de certos tipos de pessoas noticias reportagens não tão discretas que de forma alguma deveriam ser anunciadas. 
Autores em busca de audiência transformam suas novelas em palcos de diversão, temos a sujeira para os telespectadores assistirem a essas cenas, que não convém serem apresentadas as pessoas levam tão a sério tais fatos que acabam transferindo da ficção para a realidade cometendo erros diante da sociedade.

Há programas exclusivos que só falam da vida dos outros. Invadem a privacidade de artistas ou até mesmo inventam boatos inexistentes como: fulana está grávida; ciclano está infermo. São absurdos mostrados com tal frieza que conquistam a platéia.

Principalmente a televisão, deveria ser um meio de comunicação cultural, informativo e educativo. Que tenha como resultado a informação precisa para o seu público e não mostrar a mesma piada todos os dias.

\section{ANÁLISE}

Logo no título e no início do primeiro parágrafo, percebe-se que o emissor utiliza o termo "comunicação" para se referir aos meios de comunicação de massa, como televisão e rádio. Entretanto, nota-se que a tentativa de substituição não foi bem-sucedida, uma vez que a palavra "comunicação" é muito mais abrangente, por abarcar todos os processos comunicativos que utilizam as linguagens verbal e não-verbal. Assim, a tentativa de substituição (MR1-continuidade) não foi realizada de maneira adequada.

O produtor dessa redação aparenta desconhecer a estrutura de um texto dissertativo, não conseguindo desenvolvê-lo de forma eficiente. Há fuga quase que total ao tema, pois o redator escreve muito sobre o que há de ruim na televisão e não discorre em nenhum momento a respeito da liberdade de informação e sobre como evitar o abuso nos meios de comunicação. Dessa forma, não conseguiu estabelecer relações de condição e consequência, desvirtuando-se da MR4 (articulação) no que diz respeito à coerência.

Os argumentos não são consistentes, repetindo-se em vários momentos, o que revela a falta de conhecimento mais aprofundado sobre o tema e o não-poder de persuasão pelo produtor do texto, como pode ser observado nos trechos: primeiro parágrafo: "É comum em meio a comunicação o aparecimento de boatos, fofocas e a invasão de privacidade [...]”; no quarto parágrafo: "Há programas exclusivos que só falam da vida dos outros. Invadem a privacidade de artistas ou até mesmo inventam boatos inexistentes [...]”; no primeiro parágrafo: "Novelas que retratam histórias que acabam interferindo na mentalidade [...]" e terceiro parágrafo: "Autores em busca de audiência transformam suas novelas em palcos de diversão $[\ldots] ”$. 
A linguagem utilizada não está de acordo com a norma culta da língua portuguesa e em alguns momentos chega a ser rude, como pode ser observado nos trechos: no primeiro parágrafo: “[...] temos a sujeira para os telespectadores assistirem a essas cenas [...]” e no quarto parágrafo: “mostrar a mesma piada todos os dias.” A falta de adequação do texto à situação sociocomunicativa faz com que ele esteja em desequilíbrio ao conceito de situacionalidade que postula Beaugrand \& Dressler (fatores de textualidade).

Ainda sobre a linguagem, é possível afirmar que há incorporação de elementos da oralidade, os quais prejudicam a argumentação por revelar um teor de informalidade na escrita: "[...] inventam boatos inexistentes como: fulana está grávida; ciclano está infermo $[\ldots] ”$.

No segundo parágrafo, constata-se infração à MR3 (não-contradição): “Autores em busca de audiência transformam suas novelas em palcos de diversão [...]”. O argumento é totalmente questionável, uma vez que as novelas são programas de entretenimento ao telespectador e apresentam histórias de ficção, por mais que englobem situações da vida real. Fator que também reduz a credibilidade do texto, o que influencia em sua aceitabilidade pelo leitor (fatores de textualidade de Beaugrand \& Dressler).

Uma das situações mais graves encontra-se no terceiro parágrafo, o qual traz uma infração à MR3 (não-contradição): “Invadem a privacidade de artistas ou até mesmo inventam boatos inexistentes como: fulana está grávida; ciclano está infermo. São absurdos mostrados com tal frieza que conquistam a platéia.”. A frase soa estranha para o leitor, que pode questionar-se como uma situação que é mostrada com frieza pode ter a simpatia de alguém? Esse excerto exemplifica bem o que Costa Val chama de contradição léxicosemântica.

Em suma, pode-se afirmar que o texto possui problemas no que compete a todas as metarregras propostas por Charolles: MR1 (continuidade), MR2 (progressão), MR3 (nãocontradição) e MR4 (articulação).

\section{0-6}

\section{Como garantir a liberdade de informação e evitar abusos no meio de comunicação}

Nos programas de hoje estão passando informações que estão acontecendo em nosso dia-a-dia. Mas também passam informações que não tem nada a ver com o nosso cotidiano. Nos jornais, revistas, rádios e TV, tem vários absurdos que não serve para nossa vida, como 
por exemplo: informações sobre artistas, novelas, programas de comédia, piadas, etc. coisas que não serve para o nosso futuro. Apesar que também passam várias coisas boas que adquire uma boa experiência para a gente.

Quem faz as informações é o povo.

Se as pessoas parassem para pensar no que estão fazendo, as informações saíriam com mais virtude, sabedoria e liberdade. Então com isso a população iria se desenvolver e ter mais responsabilidade, pois quem faz a comunicação é a gente e não a transmissão.

Nós temos que aprender a usarmos, mais a comunicação, pois a comunicação nos trás várias coisas boas como:

- A saber falar com as pessoas, ter informações de lugares ou étcas que não aprendeu, etc.

Devemos colocar nossa comunicação e informações com muitas idéias para que depois a gente não venha fazer besteira.

\section{ANÁLISE}

Em uma análise superficial, pode-se afirmar que existe confusão por parte do emissor sobre o que é tema e o que é título, uma vez que houve a transcrição da proposta no campo para o qual se destina o título da redação. $O$ autor desconhece a estrutura dissertativa, não realizando o desenvolvimento do esquema introdução-desenvolvimento-conclusão com eficiência. Isso prejudica toda a articulação do texto (MR4), no que se relaciona, principalmente, à coerência. Sem a organização de seus argumentos, fica complicado para o emissor fazer a conexão entre causa, condição e consequência (MR2).

O texto, de uma forma geral, possui problemas ligados a todas as metarregras propostas por Charolles. Em alguns momentos, o autor constrói parágrafos muito curtos, e, em outros, extensos demais (o primeiro e segundo parágrafos, respectivamente).

Há repetição de palavras, o que denuncia a limitação de vocabulário do produtor do texto, sendo necessária adequação à MR1 (continuidade) e uso dos recursos de substituição. Os vocábulos "programa”, "pessoas", “comunicação", "informações" e "gente" são reiterados várias vezes, demonstrando o uso desequilibrado da MR1 (repetição), entretanto, conforme já exposto, a substituição lexical seria mais coerente.

A linguagem é utilizada com muita pessoalidade e desvia-se da norma culta, que é requisito para o desenvolvimento de um texto dissertativo. A falta de adequação do texto à 
situação sociocomunicativa faz com que ele esteja em desequilíbrio ao conceito de situacionalidade que postula Beaugrand \& Dressler.

Em muitos momentos, o redator deixa lacunas que comprometem o sentido da mensagem que tenta transmitir, tornando o texto um tanto quanto obscuro e impossibilitando ao leitor fazer inferências. O emissor tece comentários que não detalha e nem relaciona ao tema proposto, o que faz surgir trechos desconexos, como no último parágrafo: "Devemos colocar nossa comunicação e informações com muitas idéias para que depois a gente não venha fazer besteira". Toda essa sequência textual revela-se incoerente, pois o leitor não sabe qual seria a "besteira" a qual o autor está se referindo, nem o que ele quer dizer com “Devemos colocar nossa comunicação e informações com muitas idéias [...]”.

Não há posicionamento crítico, o emissor afirma algo e não dá prosseguimento à ideia.

Há repetição de ideias, fator que mostra o pouco conhecimento do autor a respeito do tema proposto e, também, sua falta de competência ao organizar os argumentos. Assim, sobre a informatividade (Beaugrand \& Dressler - fatores da textualidade) o autor não expõe nenhuma informação relevante, deixando a desejar nesse quesito. O produtor apenas reproduz ideias sem consistência, carentes de fundamentação.

Essas afirmações podem ser corroboradas através do primeiro parágrafo: "Nos jornais, revistas, rádios e TV, tem vários absurdos que não serve para nossa vida, como por exemplo: informações sobre artistas, novelas, programas de comédia, piadas, etc. coisas que não serve para o nosso futuro."; do segundo: “Quem faz as informações é o povo.”, e do terceiro parágrafo: "[...] pois quem faz a comunicação é a gente e não a transmissão."

O que se percebe pelos trechos acima é que não é indicado ao leitor a quem se refere as expressões "nossa vida" e "nosso futuro", nota-se que o autor se inclui no enunciado, mas não especifica a qual grupo de indivíduos ele está se referindo. O ideal é que se indique o referente para que se possa fazer a retomada textual, assim, essa sequência merece adequação à MR1, uma vez que é utilizada de forma equivocada pelo redator.

\section{2-4}

$\rightarrow$ Os programas de rádio e de TV é muito importante para a comunicação. A comunidade presizar estar atualizada aos fatos e aos acontecimentos nos dias de hoje.

$\rightarrow$ Os programas é existente para alertar. Os moradores da violência em casa e na vizinhansas e alertar também a não deixar estranhos entrar na sua residensia. 
$\rightarrow$ Em certos programas de comunicação vem dando muita audiência, por certas reportagem assistida pela comunidade.

Resumo: Pelo o que eu vejo, vem aumentado o número de audiência e o numero de vitimas em certos acontesimento.

$\rightarrow$ E no mundo enteiro vem aumentando o número de violência e de abusos contra crianças.

\section{ANÁLISE}

Pelo aspecto visual já é possível perceber que o produtor do texto desconhece totalmente a estrutura dissertativa. Não há introdução ao assunto tratado, não há desenvolvimento de ideias, nem uma conclusão adequada. Não é uma redação, o autor fez vários tópicos sobre o assunto, mas, em nenhum momento, fez conexão entre os argumentos (MR4). Os períodos não se entrelaçam.

Há fuga parcial ao tema, uma vez que a proposta não é abordada em sua totalidade, não discorrendo de maneira clara sobre como garantir a liberdade de expressão e evitar abusos nos meios de comunicação. Faltam pontos de vista elaborados e aprofundamento ao tema.

Não há progressão (MR2), pois os argumentos não são apresentados em uma sequência lógica, o que comprova a total carência de organização textual. Os comentários trazidos ao leitor são inconsistentes e sem persuasão, sendo genéricos demais, como por exemplo: "Os programas de rádio e de TV é muito importante para a comunicação" e "Em certos programas de comunicação vem dando muita audiência, por certas reportagem assistida pela comunidade.". São sequências vazias de significação, não colocando nada de novidade ao leitor.

Assim, sobre a informatividade (Beaugrand \& Dressler), o autor não expõe ideias relevantes, deixando a desejar nesse quesito, apenas reproduz informações sem consistência, carentes de fundamentação.

Constata-se o caráter não-impessoal do texto no trecho designado "Resumo: Pelo o que eu vejo, vem aumentado o número de audiência e o numero de vitimas em certos acontesimento.”, o que não é aceito pela modalidade escrita dissertativo-argumentativa. A falta de adequação do texto à situação sociocomunicativa faz com que ele esteja em desequilíbrio ao conceito de situacionalidade que postula Beaugrand \& Dressler.

As palavras "programas", “comunicação" e "violência" são repetidas (MR1repetição) exaustivamente, fato que prejudica a argumentação, visto que o texto é enxuto 
demais e necessitaria que a MR1 fosse mais explorada no que diz respeito à substituição, fazendo uso de sinônimos, por exemplo. Nos dois primeiros tópicos, existe paralelismo que confere um caráter automático e empobrecido ao texto: primeiro tópico: "Os programas de rádio e de TV é muito importante para a comunicação" e segundo tópico: "Os programas é existente para alertar.”.

Em alguns períodos não há coerência alguma, como no exemplo: ”[...] vem aumentado o número de audiência e o numero de vitimas em certos acontesimento.”. O leitor fica sem saber quem são as vítimas e quais são esses acontecimentos, ficando obscuro para ele fazer qualquer inferência. É interessante observar que o autor utiliza o verbo "aumentando" para se referir à "audiência” e às "vítimas", mas não estabelece nenhuma relação entre esses termos. Não realiza nenhuma avaliação de congruência. Para o leitor, essa sequência textual causa estranhamento por não explicitar a relação entre as duas ideias, o que se desvia do que requer a MR4 (articulação).

O texto analisado necessita de reestruturação, uma vez que apresenta graves problemas no que se refere à coesão e à coerência. Assim, precisa de adequações a todas as metarregras postuladas por Charolles.

\section{8-3}

Como garantir a liberdade de informação e evitar abusos no meio de comunicação

Garantir a liberdade de enformação e coloca em pratica todo seu conhecimento adiquirido.

Uma pessoa pode evitar, agreções e abusos, normalmente quando se estar falando ao telefone, Ex.: Aló quero fala com Dr. Ana e as pessoas falam você ligou errado, o endividuo, agride com palavroes.

Devemos ter mais respeito pelo próximo, e altoridade, quando uma pessoa e o indevidu agride, devemos pedi obrigado pela enformação, e desculpas, e fingir que nada; aconteceu.

Devemos garantir qualquer tipo de enformação, e evitar agreções e abusos no meio de comunicação. devemos respeito a humanidade em que vivemos, todos juntos devemos respeita a capasidade de cada um, não so do telefone, fisicamente, verbalmente, fingir que não viu nada não e bom: o melhor e a pessoa fica no cantinho cem dizer nada. 


\section{ANÁLISE}

Em uma análise superficial, pode-se afirmar que existe confusão por parte do emissor sobre o que é tema e o que é título, uma vez que houve a transcrição da proposta no campo para o qual destina-se o título da redação. O autor não demonstra conhecimento da estrutura dissertativa, não realizando o desenvolvimento do esquema introdução-desenvolvimentoconclusão com eficiência. Isso prejudica toda a articulação do texto (MR4), no que se relaciona, principalmente, à coerência. Sem a organização de seus argumentos fica complicado para o emissor fazer a conexão entre causa, condição e consequência.

Percebe-se que o emissor utiliza o termo "informação" de uma forma muito restrita, relacionando-o à informação que se pede por telefone. Esse uso não foi bem-sucedido, pois o tema proposto relaciona-se ao meios de comunicação de massa, como televisão, rádio, revistas. Assim, houve falta de articulação da temática proposta no texto, levando à infração da MR4.

Há repetição lexical, o que mostra o vocabulário limitado do autor. Existe, também, a ocorrência de paralelismos que cria sequências automáticas e empobrecidas de argumentação: quando inicia o terceiro parágrafo: "Devemos ter mais respeito pelo próximo [...]”; no começo do quarto parágrafo: "Devemos garantir qualquer tipo de enformação [...]” e "[...] devemos respeita a capasidade de cada um [...]". Assim, pode-se afirmar que o mau uso da MR1 (continuidade-repetição) acentuou ainda mais a limitação lexical do emissor, prejudicando, também, a progressão do texto (MR2). Além disso, a carência de uso dos conectores (MR4-articulação) comprometeu a conexão entre parágrafos e frases, a qual constituiu danos à argumentação do texto.

O texto apresenta graves falhas no que diz respeito à coerência. No terceiro parágrafo, por exemplo, o redator escreve "Devemos ter mais respeito pelo próximo, e altoridade, quando uma pessoa e o indevidu agride, devemos pedi obrigado pela enformação, $\boldsymbol{e}$ desculpas, e fingir que nada; aconteceu.”. Argumentos totalmente contraditórios, uma vez que um indivíduo que tem autoridade nunca deixaria de impor respeito se fosse agredido verbalmente, como também, não iria agradecer por ter sido desrespeitado. Nesse momento, verifica-se a infração da MR3 (não-contradição interna), pois não há concordância entre as proposições.

No último parágrafo, também, ocorre desvio do que propõe a MR3 (não-contradição): "[...] fingir que não viu nada não e bom: o melhor e a pessoa fica no cantinho cem dizer nada.”. Mais uma vez, há infração dessa metarregra, pois o emissor se contradiz. Primeiro, 
ele expõe que não é bom fingir que nada aconteceu quando se é agredido, para logo em seguida afirmar que o ideal é não se dizer nada e resignar-se, aceitando o que aconteceu.

\section{1-8}

\section{Imprensa ajuda e prejudica}

Os meios de comunicação tornou-se uma ameaça a vida dos seres humanos independente de classe social. A imprensa em massa não escolhe seu alvo. Mas uma pergunta permanece na cabeça de todos: O que fazer para controlar esse abuso e manter informações diárias?

Falta nestes profissionais da imprensa uma simples palavra "ética proficional". A falta de treinamento e ensinamento a estes cidadões é o fator que mais contribui exessivamente para esta falta de profissionalismo.

Gostando ou não a imprensa é indispensável no dia-a-dia de todos os seres racionais. É através dela que as informações diárias mais importantes e até as menos importantes chegam até as casas do povo.

Todo o mundo beneficia-se com a comunicação indo de idosos, jovens, adultos e até mesmo criança. Porém, estes mesmos que se beneficiam terminam prejudicando-se. Perdendo direito a privacidade, intimidade, sendo que estes são invioláveis.

\section{ANÁLISE}

No primeiro parágrafo, o autor se pergunta: "O que fazer para controlar esse abuso $e$ manter informações diárias?", mas não fornece resposta à questão. O produtor propõe-se a realizar algo, mas não o realiza. Revelando dificuldade em articular o tema ao seu texto (MR4).

Em toda a produção há argumentos sem fundamentação, os quais podem ser facilmente questionados pelo leitor, tais como "a imprensa é indispensável no dia-a-dia de todos os seres racionais"; e "Os meios de comunicação tornou-se uma ameaça a vida dos seres humanos independente de classe social.". Esses comentários comprometem a aceitabilidade do texto, uma vez que o leitor pode refutar essas ideias.

No quarto parágrafo, percebe-se que o emissor utiliza o termo "comunicação" para se referir aos meios de comunicação de massa, como televisão e rádio. Entretanto, nota-se que a tentativa de substituição não foi bem-sucedida, uma vez que a palavra comunicação é muito 
mais abrangente, por abarcar todos os processos comunicativos que utilizam as linguagens verbal e não-verbal. Assim, a tentativa de substituição (MR1-continuidade) não foi realizada de maneira adequada.

Há fuga parcial ao tema, pois o emissor não discorre sobre a proposta temática com clareza. Além disso, o texto necessita de recursos coesivos, de conectores que possam estabelecer entrelaçamento das ideias (MR4-articulação).

De uma forma geral, falta posicionamento crítico ao redator e organização na exposição de ideias, o que mostra, também, necessidade de adequação à MR2, pois não há equilíbrio entre continuidade temática e progressão semântica.

A redação apresenta em toda a sua extensão lacunas textuais que dificultam o entendimento do texto. Revelam-se problemas com relação às habilidades de leitura e escrita por parte do autor, além de pouco domínio da estrutura do texto dissertativo.

\section{8-5}

Presenciamos nos dias de hoje, uma sociedade que acha que liberdade de informação é abusar dos meios de comunicação. A imprensa não mais segura segue os conceitos da ética, expondo pessoas à humilhação e ao ridículo.

São frequentes os abusos nos meios de comunicação. Os programas sensacionalistas saciam a curiosidade perversa e até mórbida da sociedade, tirando seu sucesso do drama de cidadãos humildes fato que vemos frequentemente. Essas pessoas em instrução são entrevistadas por intimidação, sem saber que estão expondo-se ao mundo.

Se faz necessária a utilização de medidas que diminuam esse assédio da mídia. Até mesmo as pessoas devem se conscientizar da sua exposição. Os governos de alguns países já vêm tomando medidas contra esses abusos. Mas, o Brasil não tem tido esse tipo de atitude, apesar de isso contradizer alguns artigos da Constituição Federal.

Podemos concluir que vivemos numa sociedade em que niguém sem vida privada. Precisamos tomar medidas contra isso, e uma das maneiras de acabar com esse abuso é seguindo o exemplo de países como Suécia e Grã-Bretanha, que têm implantado mecanismos que incentivam a auto-regulação da mídia. 
Esta produção textual inicia-se de maneira satisfatória e com progressividade.

De um modo geral, o redator faz um bom uso da MR4 (articulação), utilizando conectores, como "mas", "apesar de" e "até mesmo".

O autor utiliza-se da Constituição Federal para dar mais consistência e credibilidade ao seu argumento, estabelecendo, dessa maneira, relação de intertextualidade (fatores de textualidade de Beaugrand \& Dressler).

Há fuga parcial do tema, uma vez que se discorre sobre os abusos da mídia e esquecese da importância de se garantir a liberdade de informação.

No primeiro parágrafo, existe infração à MR3 (não-contradição) no trecho: “A imprensa não mais segura segue os conceitos da ética, expondo pessoas à humilhação e ao ridículo.". Se a imprensa segue preceitos éticos não deveria, em suas reportagens, levar pessoas ao ridículo e à humilhação. São ideias opostas, que acabam por formar um período incoerente.

O produtor do texto poderia ter utilizado a MR1 (continuidade) de uma forma mais adequada, fazendo a retomada de termos através de sinônimos, pronomes etc., evitando, desse modo, a repetição lexical. O vocábulo "abuso", por exemplo, é reiterado em todos os parágrafos da redação.

No terceiro parágrafo, também, há discordância do que orienta a MR3 (nãocontradição): "Os governos de alguns países já vêm tomando medidas contra esses abusos. Mas, o Brasil não tem tido esse tipo de atitude, apesar de isso contradizer alguns artigos da Constituição Federal.”. O trecho é confuso por em um primeiro momento dizer que o Brasil não tem criado medidas contra os abusos da mídia e, logo em seguida, afirmar que a criação dessas medidas é contra o que está na Constituição. Assim, fica a pergunta: O que o autor quis dizer? É contra a Constituição criar medidas que evitem os abusos ou ficar sem criá-las? Da forma como está colocado no texto fica ambíguo para o leitor, necessitando esse trecho de reestruturação.

Em vários momentos, o autor afirma que é preciso haver o desenvolvimento de medidas que diminuam os abusos cometidos pela mídia, mas não fornece sugestões concretas, visto que poderia ter exemplificado mais, abordando, efetivamente, o que o tema proposto solicita. 


\section{8-2}

Devemos respeitar as informações passada para as pessoas, Quando um jornalista for fazer uma reportagem que pode afetar a vida de uma pessoa, essa reportagem deve ser Analisada e legalizada pelo observatório da Imprensa para que evite problemas mais tarde. Devemos ter informações de tudo que acontece realmente no mundo, somente no mundo o que acontece. Reporte que transmite informações falsas devem ser punidos porque isso é uma falta de respeito com o publico, eles armam para ganhar dinheiro e o publico, eles armam para ganhar dinheiro e o publico acaba sendo prejudicado. Devemos lutar para acabar com esse tipo de informações e ter direito a informações que todos devem saber.

\section{ANÁLISE}

O aspecto visual da redação já demonstra a total falta de conhecimento do autor da estrutura dissertativa, visto que não há paragrafação, o que se vê é um bloco contínuo de palavras.

A redação inteira apresenta falta de organização, possuindo carência de recursos coesivos (MR4-articulação) e comprometimento em sua linearidade e coerência. A pequena extensão do texto e a superficialidade dos argumentos denunciam o conhecimento limitado do emissor sobre o assunto. O tema, também, não foi abordado em sua totalidade, pois o autor focou-se nos abusos da mídia e não discorreu sobre como garantir a liberdade de informação.

Em alguns momentos, há trechos que são ininteligíveis: "Devemos ter informações de tudo que acontece realmente no mundo, somente no mundo o que acontece.”. É um comentário desconexo, que não traz nenhuma informação extra ao leitor e ainda prejudica a argumentação. Percebe-se, dessa forma, comprometimento da progressão do texto, uma vez que há desvio do que postula a MR2.

Há repetição lexical, o que mostra o vocabulário limitado do autor. Existe, também, a ocorrência de paralelismos que criam sequências automáticas e empobrecidas de argumentação: "Devemos respeitar as informações passada para as pessoas [...]"; "Devemos ter informações de tudo que acontece realmente no mundo [...]"; "Devemos lutar para acabar com esse tipo de informações [...]”. Assim, pode-se afirmar que o mau uso da MR1 (continuidade-repetição) acentuou ainda mais a limitação lexical do emissor, prejudicando, também, a progressão do texto (MR2). Além disso, a carência de uso dos conectores (MR4- 
articulação) comprometeu a conexão entre frases e ideias, a qual constituiu danos à argumentação do texto.

Por fim, as duas últimas linhas destinadas à conclusão mostram comentários sem fundamentação, nos quais o autor não se posiciona criticamente, nem fornece sugestões concretas para a resolução dos problemas.

\section{0-2}

Ao longo dos anos os variados meios de comunicação estão mais presentes no nosso cotidiano apresentando-se de várias maneiras, seja pelo rádio, jornais, revistas, TV’s cartas, internet... Todos visando levar aos seus usuários a informação. Mesmo que possam estar violando a intimidade de seu principal cliente.

Sempre se acompanhou o desenvolver da história os acontecimentos atuais pelos diferentes meios de mensagens facilitados pelas descobertas e invensões como a escrita para cartas, jornais e revistas ou para o avanço tecnológico TV, rádio, internet. Apreciamos últimamente notícias fresquinhas no momento em que ocorreram. A televisão se faz constante a vida de todos, por ela, apreciamos tudo que ocorre no mundo.

Porém, a fascinação pela chamada audiência ou furo de reportagem vem atingindo diversos niveis das classes sociais, colocando em risco a vida daqueles são a notícia mas nem sempre querem sê-la. Fazer publica a vida do outro, faz com que profissionais nesse ramos cheguem a perder o limite do perigo, infiltrar-se sem medo, ter a informação rompe qualquer barreira que possa impedi-los de tornar-se vista vidas comuns, públicas ou marginais. Um fato que nós ilustra-se é a morte de Tim Lopes, jornalista que foi morto por traficantes na favela do Vigário Geral no Rio de Janeiro, pego quando fazia filmagens do comércio de tráfico de drogas. A mídia quer vender o produto, não importa o risco. Adotamos seu padrão de beleza, criticamos vidas alheias, rimos do sofrimento dos outros esquecendo-se que somos parte desse produto. Portanto, a Impresa precisa de correções, freios e regulamentações evitando que coloque em risco a vida das pessoas. É mas digno promover o conhecimento cultural, a educação, a cidadania. Sensacionalismo pode dar o $1^{\circ}$ lugar na audiência, retirando a moral e os principios. 
De modo geral, essa redação apresenta razoável nível de coerência, pois o autor não comete falhas graves nesse quesito.

Entretanto, há fuga parcial ao tema, uma vez que o redator se concentra em discorrer a respeito dos abusos realizados pela mídia e não expõe nada sobre a liberdade de informação.

O autor, em alguns momentos, faz bom uso de conectores (MR4-articulação), tais como: "porém" e "portanto", presentes no último parágrafo. No entanto, a MR4 poderia ter sido melhor explorada, pois em alguns trechos, o leitor percebe a falta de ligação entre as frases.

É possível encontrar paralelismos (MR1-continuidade) com o intuito de enfatizar as influências ruins mostradas pela mídia e conferir mais persuasão ao argumento: “Adotamos seu padrão de beleza, criticamos vidas alheias, rimos do sofrimento dos outros esquecendose que somos parte desse produto.”. Por outro lado, o autor deixa de utilizar recursos de substituição em certos trechos em que repete a enumeração "rádio, jornais, revistas, TV's cartas, internet.”.

A linguagem é utilizada com pessoalidade por meio do uso dos verbos: "apreciamos" "adotamos" "criticamos" "rimos" e em alguns trechos é influenciada pela oralidade ("notícias fresquinhas"), desviando-se da norma culta, que é requisito para o desenvolvimento de um texto dissertativo. A falta de adequação do texto à situação sociocomunicativa faz com que ele esteja em desequilíbrio ao conceito de situacionalidade.

A progressão (MR2) fica comprometida em trechos como no primeiro parágrafo: “Ao longo dos anos os variados meios de comunicação estão mais presentes no nosso cotidiano apresentando-se de várias maneiras, seja pelo rádio, jornais, revistas, TV's cartas, internet [...]". O uso do conectivo "seja" pressupõe que há continuação da frase, "seja por uma coisa ou por outra", mas sem o complemento, a sequência soa estranha para o leitor, que percebe a inconclusividade do período.

Ao fornecer o exemplo do jornalista Tim Lopes, o produtor demonstrou capacidade de realizar relação entre seu conhecimento de mundo e o tema proposto, realizando conexão entre eles (MR4) e, desse modo, conseguindo contribuir para a argumentatividade do texto e aumentando sua informatividade.

O último parágrafo é extenso demais, ao qual se mistura a uma conclusão feita pelo autor, que não se mostra bem fundamentada por ser apenas uma solução muito genérica e reproduzir o senso comum. 


\title{
0395419-6
}

\section{Redação}

A imprensa tem o sentido de invadir lugares não beneficiados em favelas, morros, avenidas para entrevistar os criminosos que cometem vários crimes sem pedir licença.

Mas muitos deles acabam morrendo nas mãos dos criminosos.

O exemplo deles é o jornalista Tim Lopes que estava com câmera escondida filmando a vida de alguns bandidos. Ele era considerado o melhor jornalista da rede Globo de televisão. Sendo assim, os bandidos continuam aterrorizando pessoas fazendo delas escravos, sem ter para onde ir, sem ter o que comer, beber e que não têm família.

O que será de nós no futuro?

\begin{abstract}
ANÁLISE
A redação inteira apresenta falta de organização, fator que compromete sua linearidade e coerência. O redator revela o desconhecimento da estrutura dissertativa até pela generalidade do título, denominado "Redação". A pequena extensão do texto e a superficialidade dos argumentos denunciam o conhecimento limitado do emissor sobre o assunto. O tema não foi abordado em sua totalidade, pois o autor focou-se nos abusos da mídia e não discorreu sobre como garantir a liberdade de informação.

Não há uma continuidade adequada (MR1), uma vez que há repetição lexical de “criminosos", "bandidos”. Há, também, trechos redundantes que comprometem a progressão do texto (MR2). No primeiro parágrafo, por exemplo, o autor escreve "criminosos que cometem vários crimes”. Toda essa reiteração interfere na argumentatividade que não convence o leitor pela falta de embasamento e profundidade dos comentários apresentados.

Em alguns momentos, surgem períodos incompreensíveis, como: "A imprensa tem o sentido de invadir lugares" ou "[...] os criminosos que cometem vários crimes sem pedir licença [...] muitos deles acabam morrendo nas mãos dos criminosos.”. Esta última frase não possui qualquer nexo, pois, do modo como foi estruturada, informa que os criminosos são mortos por eles mesmos, mostrando-se, assim, totalmente incoerente, o que fere o princípio da não-contradição (MR3).

O último parágrafo, que deveria ser destinado à conclusão do texto, não expõe nenhuma solução para a problemática proposta, não há posicionamento crítico, nem fundamentação. O que se vê é uma pergunta retórica, vaga de sentido e incoerente ao
\end{abstract}


contexto, o que leva ao total distanciamento do que exige um texto dissertativo, no qual é essencial a argumentação e criticidade.

\section{4-7}

\section{Televisão meio deturpado de comunicação}

O homem absorve mais o que vê do que ouve ou sente. Os nossos olhos são uma grande porta de conhecimento, tudo que vimos é absorvida direto ou indiretamente. A imprensa utiliza esse meio de absorção como fonte geradoura de renda, mas é imposto um conhecimento muitas vezes de maneira cruel.

A nossa televisão tem sido um meio de comunicação e informação que visa prioritariamente o lucro, somos obrigado a acolher em nossas casas programas que deturpam a criação de nossos filhos. A sexualidade é jogada na televisão de maneira escancarada visando uma atuação maior direcionada aos produtos.

Os programas expõem a vida e a intimidade do homem de modo escancarado, não se respeitam mais os horários que nossos filhos poderiam estar aprendendo algo de útil na televisão.

Quando a imprensa respeitar os direitos de cada cidadão e se conprometer a fazer programas que visem lucro justamente com conhecimento e informação de boa qualidade teremos um grande aliado par dar uma educação correta aos nossos filhos.

\section{ANÁLISE}

O texto inicia-se com a afirmação "O homem absorve mais o que vê do que ouve ou sente", entretanto o autor não expõe com base em quê foi constatado isso, não fornece fundamentação. Sendo assim, temos um comentário genérico que reflete o senso comum, passível de questionamento pelo leitor, comprometendo, dessa forma, a aceitabilidade do texto.

Em outro trecho, o emissor afirma que "somos obrigado a acolher em nossas casas programas que deturpam a criação de nossos filhos", argumento totalmente refutável, já que o espectador pode trocar de canal e até mesmo desligar a televisão.

Há em todo o texto repetição lexical de "filhos", "televisão", "homem", "programa" que prejudicam sua continuidade (MR1) como, também, sua progressão (MR2), por ser 
redundante na apresentação de argumentos, como pode ser observado nos trechos do segundo parágrafo: "programas que deturpam a criação de nossos filhos”; do terceiro parágrafo: “[...] não se respeitam mais os horários que nossos filhos poderiam estar aprendendo algo de útil na televisão"; e do quarto parágrafo: "par dar uma educação correta aos nossos filhos.". Essa demasiada repetição prejudica o nível de informatividade, uma vez que reitera a mesma ideia e não traz nada de novo ao leitor.

A linguagem utilizada, em alguns momentos, mostra influência da oralidade: " $A$ sexualidade é jogada na televisão de maneira escancarada" e "Os programas expõem a vida e a intimidade do homem de modo escancarado [...]". Além disso, há o uso frequente do pronome possessivo "nosso(s)" pelo qual se constata o caráter não-impessoal do texto, o que não é aceito pela modalidade escrita dissertativo-argumentativa. A falta de adequação do texto à situação sociocomunicativa faz com que ele esteja em desequilíbrio em relação ao conceito de situacionalidade.

De uma maneira geral, faltam à dissertação recursos coesivos de retomada (MR1continuidade) e conectores que estabeleçam ligação entre as frases e os parágrafos (MR4articulação).

Há fuga parcial ao tema, uma vez que o autor se preocupa apenas em discorrer sobre a má influência da televisão, não englobando, assim, o tema em sua totalidade. Faltam pontos de vista mais elaborados e ideias adequadas ao real objetivo do texto.

\section{3-6}

A sociedade brasileira para buscar seus direitos por lei, acaba recorrendo a imprensa, e não à justiça. Os meios de comunicação, também infringe as leis estabelecida em nosso país, mas com este sistema existente, fica difícil puni-lo.

A imprensa brasileira criou uma imagem de "pais dos oprimidos". Porque a justiça é lenta, e os governantes não gosta de ter suas imagens desvalorizada diante do público, porque qualquer situação de descaso refletirá no seu governo. E com isso a imprensa se utiliza desses meios para explorar a sociedade.

Os meios de comunicação, aliena os seus públicos, colocando programas e materiais que não contribui em nada a cultura da sociedade. Porque cultura na "sociedade robô" não dá ibope, e isto é o seu principal objetivo. A exemplo do programa fantástico, exibindo cenas do BOPE (batalhão operações especiais) subindo no morro da favela, trocando tiros, onde houve 
policiais e marginas feridos, como se fosse cena de filme policial. As imprensas cometam seus erros e a justiça não toma providências rigorosas, como se a justiça responsável por atos deste tipo ficasse nas mãos deles, ou melhor, devesse obdiência.

Portanto tem que se tomar atitude drásticas, para que limites seja obdecido. E a sociedade fiscalize, e não ver a imprensa como justiça e sim como meio de comunicação. Senão o artigo quinto da constituição federal, que diz; todo cidadão tem o direito de ir e vir existirá só no papel.

\section{ANÁLISE}

Uma análise superficial do texto revela problemas com o uso de elementos de coesão textual, grande repetição de vocábulos devido à pobreza vocabular, pouco conhecimento do tema abordado e dificuldades em relação à estruturação do texto escrito.

O posicionamento ideológico do autor apresenta incoerências argumentativas, principalmente quando generaliza afirmações que, posteriormente, são refutadas no decorrer do processo dissertativo, ocasionando dificuldades interpretativas para o leitor apreender o real sentido do texto.

O redator não deixou claro o que quis dizer com a expressão "sociedade robô", afinal não há esclarecimento posterior, o que nos remete a uma falha em relação à MR1 (continuidade), já que a expressão não retoma nenhuma ideia já colocada no texto.

No primeiro parágrafo, percebe-se, também, que há retomada textual com a expressão "este sistema", sem o autor explicitar a qual sistema está se referindo. A pronominalização seria aceitável desde que tivesse sido indicado qual ideia "este sistema" está substituindo. O referente deveria ter sido apresentado ao leitor, para depois, de forma anafórica, ser utilizada a expressão em seu lugar. Verifica-se, desse modo, uma nova discordância à MR1 (continuidade).

No terceiro parágrafo, percebe-se que há a tentativa, por parte do redator, em fornecer exemplos que corroborem seus argumentos, o que de fato confere informatividade ao texto. Assim, o produtor demonstrou capacidade de fazer relação entre seu conhecimento de mundo e o tema proposto, realizando conexão entre eles (MR4).

No último parágrafo, a Constituição Federal é citada (intertextualidade-fatores de textualidade de Beaugrand \& Dressler), no entanto, não se percebe pertinência no restante do texto, visto que o autor não acrescenta nada e nem se mostra coerente ao tema tratado. 


\section{9-5}

Afirmam-se que a mídia é abusadora das desgraças e benefícios alheios da população de baixa renda principalmente, mas há quem goste desse abuso. Não há reclamações porque certas pessoas não chegam a ter acesso dos seus direitos e isso os poderosos acabam invadindo a privacidade dos outros sem que eles menos percebam.

Um exemplo, um jornal digo: divulgou que Antonio Carlos Magalhães estava a passeio com sua namorada na Praia; caso fosse um homem de baixa renda teria homem passeia com sua amante em uma praia, olha a palavra namorada para amante como é pesada. Um outro exemplo, um radialista falava de um candidato a prefeito de sua cidade e dias depois apareceu morto, o que isso quer dizer? Que ainda existe a censura abafada.

Nós só sabemos o que eles querem, ou seja, a imprensa é para classe alta, pois a baixa é tudo distorcido ainda vivemos numa ditadura camuflada e não nos demos conta disso. Há leis e tudo mais, mas de que adianta se não cumprida.

\section{ANÁLISE}

O autor possui dificuldade em utilizar a norma culta, apresentando falhas no que compete à estruturação formal do texto. Os desvios comprometem a compreensão, pois muitas vezes o leitor percebe-se em meio a sequências ininteligíveis, como no trecho retirado do segundo parágrafo: "Antonio Carlos Magalhães estava a passeio com sua namorada na Praia; caso fosse um homem de baixa renda teria homem passeia com sua amante em uma praia, olha a palavra namorada para amante como é pesada.”.

O redator não apresenta as ideias de maneira clara e peca pela falta de uso de recursos coesivos. O texto é muito carente de organização, necessitando de adequações à MR4 (articulação). Os argumentos apresentados são desconexos, o que demonstra a falta de conhecimento do autor sobre a temática. $\mathrm{O}$ autor se prende muito aos exageros cometidos pela mídia e não discorre a respeito da liberdade de informação, que também deve ser abordada no desenvolvimento do texto. Por isso, o autor foge, parcialmente, do tema ao não contemplá-lo em sua totalidade.

No primeiro parágrafo, há ambiguidade quando o emissor escreve que: “Não há reclamações porque certas pessoas não chegam a ter acesso dos seus direitos e isso os poderosos acabam invadindo a privacidade dos outros sem que eles menos percebam.". Não está claro para o leitor se o uso da pronominalização visa retomar "poderosos" ou "outros", o 
que dificultou o estabelecimento da coerência, evidenciando o desrespeito à MR1 (continuidade).

No segundo parágrafo, há a citação do nome "Antônio Carlos Magalhães", sobre o qual o autor não tece nenhuma explicação, não mostrando a relevância deste nome estar no texto. Muitas pessoas podem não conhecê-lo, por isso o emissor deveria ter contextualizado, informando que o indivíduo citado foi um político importante para a Bahia e para o Brasil, polêmico por sua popularidade e pelas denúncias de conduta corrupta. Tudo isso revela, mais uma vez, infração à MR4 (articulação), no que se relaciona à coerência.

O texto apresenta em toda a sua extensão lacunas textuais que, mesmo complementadas pela ação interpretativa do leitor, dificultam o entendimento do texto. Revelam-se problemas com relação ao domínio de habilidades de leitura e escrita por parte do autor, além de pouco domínio da estrutura do texto escrito.

\section{3-0}

A realidade e a clareza com que vem sendo apresentado os meios de comunicação estão causando curiosidade de saber onde vai chegar tal cena e pouco de transtorno dos telespectadores.

Segundo a reportagem de Eugênio Bucci (São Paulo 2000) o jeito em que a mídia transmite suas reportagens muitas vezes chega a ser absurda. Como casos de pequenos crimes, pai ou outro familiar que estrupa crianças, etc é tirada a privacidade do cidadão que por sua vez não pode opnar.

Um problema não é Brasileiro mas mundial e não se torna só das empresas privadas e sim de muitos jornalistas onde o artigo $5^{\circ}$ diz ser livre a atividade intelectual do artista independente de licença ou não.

Cabe ao departamento responsável por tal reaver algumas providencias para garantir a segurança na comunicação e tentar resolucionar o já está virando problema.

\section{ANÁLISE}

De uma forma geral, há falta de articulação (MR4) no que diz respeito à coerência. Inicia-se uma ideia e não se efetua sua conclusão, situação que não possibilita ao leitor compreender a mensagem que se deseja transmitir, o que pode ser observado no segundo 
parágrafo: "Como casos de pequenos crimes, pai ou outro familiar que estrupa crianças, etc é tirada a privacidade do cidadão que por sua vez não pode opnar”. As lacunas textuais presentes nesse trecho prejudicam o entendimento por não possuírem conectores que estabeleçam relação entre um argumento e outro. Não há avaliação de congruência.

Todo o texto é carente do uso de elementos coesivos, fato que prejudica diretamente sua coerência, pois com a falta de articuladores (MR4) não é estabelecida conexão entre os períodos e, além disso, as ideias não se entrelaçam. Por essas razões, a compreensão do que está sendo dito fica comprometida, pois não há clareza, nem organização dos argumentos.

O autor não fornece informações novas, nem defende um ponto de vista, pois o que se vê é apenas uma reprodução das ideias provenientes dos textos-base. O redator faz, de certa forma, uma relação de intertextualidade, citando o autor Eugênio Bucci, mas não acrescenta nenhum posicionamento crítico, ficando o leitor sem entender o motivo da citação, uma vez que não se percebe a ligação entre os argumentos. $\mathrm{O}$ mesmo acontece quando o produtor faz referência à Constituição.

Percebe-se em todo o texto, que há falta de progressividade (MR2), revelada, principalmente, pela carência de organização textual, não havendo, dessa maneira, equilíbrio entre continuidade temática e progressão semântica. Nesse texto, não é possível reconhecer ordenação de causa-consequência entre os argumentos expostos pelo produtor da redação.

$\mathrm{Na}$ conclusão, a proposta feita é simplista, apenas refletindo o senso comum. O redator não traz nenhuma sugestão concreta que possa servir de solução à problemática proposta pelo tema.

\section{8-9}

\section{Como garantir a liberdade de informação e evitar abusos nos meios de comunicação?}

O Brasil, um país com suas proprias leis baseado no que se vive, em comportamentos diferenciados e com acordo das Nações Unidas; sendo que para cada tipo de comportamento ha uma lei.

Muitos brasileiros pensam que sabem dos seus direitos, sendo que o direito que a mídia passa, é o de ir e vir. Usando e abusando desse direito esquecem ou fingem que não sabem que existem outros deveres a cumprir, e fazendo assim infringem a lei. 
As pessoas verdadeiramente não sabem dos seus direitos, mas sabem que têm e como têm deveres a serem cumpridos, e sempre ouve que não pode isso ou aquilo. Contudo, passam, as vezes, por cima da lei e fazem o que é irado para sobreviverem.

A mídia já que tão culta, pode entrar em comum acordo com seus entrevistados, respeitando-os, pois um precisa do outro: um para sua subsistência e sucesso e o outro para sua informação diária.

ANÁLISE

Essa dissertação foge quase que totalmente do tema proposto. O texto, muito enxuto, apresenta desvios de estruturação formal, tais como: ortografia, acentuação, concordância verbal/nominal e pontuação.

O título foi confundido com o tema da dissertação, deixando o redator de explorar a temática desde o início do texto. De uma forma geral, há falta de articulação (MR4) no que diz respeito à coerência. Inicia-se uma ideia e não se efetua sua conclusão, situação que não possibilita ao leitor compreender a mensagem que se deseja transmitir.

Nota-se, também, que não há continuidade (MR1), tendo em vista que as palavras são repetidas e o texto fica empobrecido de recursos de retomada textual, tais como: sinônimos, pronomes ou advérbios.

No primeiro parágrafo, por exemplo, é construída a introdução “O Brasil, um país com suas proprias leis baseado no que se vive, em comportamentos diferenciados e com acordo das Nações Unidas; sendo que para cada tipo de comportamento ha uma lei.”. É possível perceber que o autor não conclui a caracterização do Brasil, nem da situação atual em que está o país, para, então, apresentar o argumento de que há uma lei para cada tipo de ocorrência ou infração.

Esse parágrafo é carente do uso de elementos coesivos, fato que prejudica diretamente a coerência do texto, pois com a falta de articuladores (MR4) não é estabelecida conexão entre os períodos e as ideias não se entrelaçam.

A expressão "sendo que" deveria ter sido utilizada para destacar a primeira ideia exposta, estabelecendo relação congruente e conferindo mais credibilidade ao argumento, uma vez que o uso dessa expressão pressupõe que algum comentário concreto tenha sido feito anteriormente, o que não aconteceu nesse trecho. Por essas razões, a compreensão do que está sendo dito fica comprometida, pois não há clareza nem organização dos argumentos. 
No segundo parágrafo, há a utilização equivocada, também, da expressão "sendo que", para a qual está sendo atribuída uma função adversativa. $\mathrm{O}$ autor, provavelmente por sua limitação do conhecimento da estrutura textual, não faz uso de outros conectores, o que destoa do que estabelece a MR4. No trecho "Muitos brasileiros pensam que sabem dos seus direitos, sendo que o direito que a mídia passa, é o de ir e vir”, verifica-se que o autor não realiza nenhuma apresentação prévia ao leitor, dizendo que vai discorrer sobre a influência da mídia. Assim, ele não situa o leitor para que receba a mensagem proposta, deixando a sensação de que as informações estão "soltas".

O terceiro e quarto parágrafos apresentam graves problemas de coerência, necessitando de reestruturação e reescrita para que se possa compreendê-los, sendo necessárias adequações às MR1, MR2 e MR4.

É importante salientar que há uma forte contradição entre argumentos dos segundo e terceiro parágrafos. No segundo: "Usando e abusando desse direito esquecem ou fingem que não sabem que existem outros deveres a cumprir [...]"; e no terceiro: "As pessoas verdadeiramente não sabem dos seus direitos, mas sabem que têm e como têm deveres a serem cumpridos [...]", podemos verificar que há desvio do que postula a MR3 (nãocontradição).

Apenas no quarto parágrafo o emissor discorre sobre o tema proposto de uma maneira mais explícita, sugerindo que os meios de comunicação evitem abusos. Apesar disso, toda essa passagem apresenta-se fora da MR1 (continuidade) e constitui-se ambígua.

\section{0-1}

\section{Como garantir a liberdade de informação e evitar abusos nos meios de comunicação?}

Primeiramente respeitando o cidadão com: informando a ele que a imprensa necessita de informações de sua vida, seja pessoal, trabalho, etc.

Acaso o cidadão não permita a esse tipo de invasão e bom respeitá-lo mas nem sempre isso acontece, eles invadem de qualquer jeito da maneira mais absurda para ter informação.

Quem mais sofre com essa situação é a classe baixa, deixando o coitado do cidadão tão sem graça, mostrado tudo da vida dele, o que faz ou fez de bom e ruim e como leva sua vida no dia-a-dia.

As vezes por uma bobagem sem a menor importância a impressa invadem logo grava tudo sem perder nenhum detalhe e vai para a televisão ou jornal.

Enquanto os poderosos fazem e acontecem e levam séculos para descobrir. 
Pensando no constrangimento que o cidadão vai passar a impressa deveria aliviar um pouco. Assim séria garantir a liberdade de viver sem constrangimento.

\section{ANÁLISE}

O texto evidencia desvios à norma, tais como: pontuação, ortografia, regência verbal, concordância verbal/nominal, acentuação etc. Apresenta, também, inadequação vocabular, pois a linguagem com a qual o texto foi produzido não é condizente ao contexto de produção que exige uma variedade formal - a norma culta.

A oralidade bem como a pessoalidade estão fortemente presentes, exemplificadas em vários trechos, tais como: "deixando o coitado do cidadão tão sem graça”; "Enquanto os poderosos fazem e acontecem e levam séculos para descobrir."; “As vezes por uma bobagem sem a menor importância”. Tais termos não são adequados ao contexto de produção em que estão inseridos, fato que os deixa em desacordo no quesito situacionalidade. Dessa forma, desvirtua-se do que cabe à situação sociocomunicativa.

O autor não apresenta conhecimento da estrutura dissertativa, uma vez que não reconhece o tema como proposta para o desenvolvimento de seu texto e sim, como uma simples pergunta, o que pode ser verificado no primeiro parágrafo.

No segundo parágrafo, percebe-se que há a utilização do recurso de retomada textual “eles”, sem o autor explicitar a quem está se referindo. É inevitável a pergunta: Eles quem? A pronominalização seria aceitável desde que tivesse sido explicitado a quem "eles" está substituindo. O referente deveria ter sido apresentado ao leitor, para depois, de forma anafórica, ser utilizado o pronome em seu lugar. Verifica-se, desse modo, discordância à MR1 (continuidade), no que diz respeito à substituição gramatical.

Falta em todo o texto consistência aos argumentos, que são apresentados de maneira superficial, baseados no senso comum e não em situações factíveis, visto que o redator não exemplifica de forma clara situações concretas, as quais confeririam plausibilidade à redação.

A MR4 (articulação) é utilizada de forma precária e muitas vezes não está presente no texto. Em alguns momentos, o leitor se vê em uma sequência de frases desconexas, as quais seriam minimizadas se houvesse o uso de conectivos.

$\mathrm{O}$ autor fere os preceitos da progressão, MR2, uma vez que não se preocupa em expor algo diferente do que já foi dito, não levando em consideração a necessidade de haver contribuição semântica. Assim, o seu grau de informatividade é baixo, uma vez que não traz ao leitor nada de novo. 
Ocorrem repetições de vocábulos em vários momentos, com destaque para “cidadão(s)”, que é usado quatro vezes em um texto de quinze linhas. Isso evidencia o vocabulário limitado do autor que de maneira desequilibrada fez uso da MR1, no que se refere à repetição, e não aproveitou a oportunidade para fazer a substituição do termo.

No pequeno parágrafo destinado à conclusão, a proposta que o autor faz não possui qualquer fundamento, mais uma vez corroborando a falta de conhecimento do autor sobre o assunto.

Com base na análise, percebe-se que o produtor dessa redação falhou ao manifestar sua opinião e ao construir os argumentos, os quais se deram de forma insatisfatória. Tudo isso culminou em uma total falta de organização textual e respeito à MR4 (articulação), nos âmbitos da coesão e da coerência.

\section{6-5}

\section{Como garantir a liberdade de informação e evitar abusos nos meios de comunicação?}

Quando realmente for praticada dentro da lei a Constituição, onde todos, devemos respeitar independentemente da posição ou escala social.

A garantia de liberdade de informações e abusos dos veículos de comunicação, devese em decorrência da maioria da população sem acesso as Escolas de qualidade, consequentemente essas pessoas, ficam a margem da sociedade, sem saber a quem apelar, com tudo isso, os meios de comunicações levam vantagem, porque eles são formuladores de opiniões, por falta de punição eles usam e abusam sabendo que nada ira acontecer.

Os abusos poderiam melhorar, a partir da mudança dos nossos políticos onde alguns fazem parte da oligarquia empurrando esses miseraveis para as favelas, becos e zonas periféricas.

\section{ANÁLISE}

A redação analisada possui graves desvios no que diz respeito à coerência e à coesão textual. O título foi confundido com o tema, pois o autor em vez de criá-lo apenas transcreveu a proposta em seu lugar. Além disso, percebe-se que não houve revisão, pois o texto apresenta inadequações no que diz respeito à norma culta da língua portuguesa, sendo presentes falhas na ortografia e acentuação. 
A falta de conhecimento sobre o assunto e também sobre a estrutura dissertativa é denunciada através da pequena extensão que o texto possui. Não há um parágrafo introdutório; o redator responde ao tema como se fosse uma pergunta e não uma proposta de produção dissertativa. Além disso, o primeiro parágrafo traz comentários vazios de argumentação ao afirmar que: “a Constituição deve ser praticada dentro da lei”, não fazendo nenhuma contribuição semântica, desse modo, sem informatividade.

No segundo parágrafo, vê-se nitidamente que o autor não percebe diferença entre as expressões "liberdade de informação e abusos nos meios de comunicação", pois ambas são apresentadas como negativas e equivalentes, características evidenciadas pela conjunção "e".

O autor não prestou atenção ao significado do vocábulo "abusos", utilizando-o de maneira totalmente equivocada no terceiro parágrafo, o que gerou a estranha afirmação " $\boldsymbol{O} \boldsymbol{s}$ abusos poderiam melhorar [...]”.

O último parágrafo é totalmente desconexo. O trecho "a partir da mudança dos nossos políticos onde alguns fazem parte da oligarquia [...]” possui ambiguidade, pois não está explícito que tipo de mudança deve ocorrer, se é para o povo eleger outros políticos ou se os atuais políticos devam modificar as atitudes, sendo mais honestos.

Ainda no último parágrafo, há a afirmação "empurrando esses miseraveis para as favelas, becos e zonas periféricas.” A falta de clareza faz com que o leitor se pergunte a quem o autor está designando a tarefa de "empurrar esses miseráveis"?, pois não há referente para essa ação. Aliás, a quem está se remetendo a expressão "esses miseráveis", aos políticos, ao povo ou aos meios de comunicação? Com isso, podemos afirmar que o uso feito da MR1 (continuidade) por substituição se justificaria se a utilização do pronome demonstrativo "esse" fosse feita anaforicamente, ou seja, após a apresentação do referente, situação que não comprometeria a coerência do trecho.

Falta em todo o texto a boa utilização dos recursos coesivos, sendo necessária uma adequação às MR1 (continuidade), MR2 (progressão), MR3 (não-contradição) e MR4 (articulação), tanto na coesão, quanto na coerência.

Essa redação não possui organização textual, estando muito comprometida. A argumentação realizada é praticamente incompreensível e pouco consistente e a conclusão não possui qualquer fundamentação.

Em suma, esse texto apresenta graves problemas de coesão e de coerência conforme as metarregras postuladas por Charolles, os quais influenciaram diretamente na estruturação precária e deficiente do conteúdo. Assim, o tema proposto não foi desenvolvido conscientemente. 


\section{0-3}

\section{A livre expressão é o que constrói uma nação}

A livre expressão é um direito inerente e inalienável a todos os cidadãos brasileiros. Por ser uma república democrata (o Brasil) os cidadãos tem este livre arbítrio intelectual. Alguns chegam a abusar dessa liberdade, ferindo a moral e/ou a honra de outros indivíduos. Forçando o governo a criar punições para estes indivíduos anti-éticos.

Nessas punições é que o governo falha. Está previsto na constituição brasileira, o direito de livre expressão (independentemente da censura), causando um paradoxo relativo ao mal profissional da informação. Tal falha constitucional deixa impune os profissionais incompetentes.

O, atual, presidente da república (Lula) apresentou uma proposta de censura ao mal jornalismo. Para o Brasil, que se encontra numa látima (relativo à imprensa) esta medida sem uma dádiva. Tornando os meios de comunicação (forçosamente) a uma programação de boa qualidade cultural.

Com o surgimento desta censura, haverá (certamente) uma emenda constitucional. Tornando, assim, a medida legal. Por ser um grande líder nacionalista, Lula contratará autoridades competentes para a fiscalização desta censura perfazendo do jornalismo nacional um exemplo global.

\section{ANÁLISE}

O autor apresenta pouco conhecimento da estrutura dissertativa, mas, mesmo assim, efetuou uma delimitação entre introdução, argumentação e conclusão. Entretanto, não realiza essas etapas com muita propriedade.

Apesar de alguns desvios à norma culta, essa redação não possui, necessariamente, problemas para a decodificação.

No último parágrafo, nota-se que o autor não sugere nenhuma proposta ou solução ao problema indicado. Apenas continua o comentário que teceu no terceiro parágrafo.

A conclusão é o ponto mais preocupante desse texto, pois é totalmente incoerente ao que se expõe na introdução e no título do texto: "A livre expressão é o que constrói uma nação”. Assim sendo, no plano conceitual, não há convergência com a MR3 (não-contradição interna). No início, o redator escreve que "a livre expressão é um direito de todos os cidadãos brasileiros" e na conclusão, mostra-se favorável à censura: “Com o surgimento desta 
censura, haverá (certamente) uma emenda constitucional [...] Por ser um grande líder nacionalista, Lula contratará autoridades competentes para a fiscalização desta censura perfazendo do jornalismo nacional um exemplo global”.

A falta de impessoalidade está presente na adjetivação quando menciona o presidente Lula no texto, com a expressão "grande líder", e quando afirma que o jornalismo se transformará assim que a censura for aprovada: "perfazendo do jornalismo nacional um exemplo global", trechos que explicitam a simpatia do autor para com o governo do presidente Lula.

Em alguns momentos em que o autor utiliza a MR1, realiza a metarregra de forma equivocada. Em dois desses momentos os termos estão entre parênteses, no primeiro parágrafo: "Por ser uma república democrata (o Brasil) os cidadãos tem este livre arbítrio intelectual" e no terceiro: "O, atual, presidente da república (Lula) apresentou uma proposta [...]". Percebe-se que nos dois casos os termos mais genéricos "república democrata" e "presidente da república" precedem os mais específicos "Brasil" e "Lula", mas se forem invertidos os substantivos, a relação entre os elementos linguísticos torna-se mais clara, favorecendo a coerência textual.

\section{9-7}

\section{TV Sensacionalista}

É o título que dou para o tema abordado. Não respeitam nada nem ninguém, só visam o capital e o pobre que se dane. Não estão interessados nos nossos problemas sociais mas estão interessados se eu matei alguém famoso da mídia. Porque é o que da audiência. Para nós excluídos da sociedade não há o que fazer, pois eles que comandam, eles são a burguesia. Principalmente os programas de domingo, mulheres semi-nuas e muito muito sensacionalismo para que as pessoas se sencibilizem e chorem cada vez mais e é assim todos os dias de domingo à domingo.

Para mim a solução é a concientização social, mental, se ocupando de outras formas porque se dá tanto o que fazer, do que ficar assistindo tv, ir ao parque, praia, shopping, entre outros.

Temos que pensar duas vezes antes de ligarmos a tv porque ela manipula o espectador, prende toda a sua tenção, como se fosse hipinose, é o que nós temos de pior na comunicação. 


\section{ANÁLISE}

Constata-se o caráter não-impessoal do texto logo no primeiro parágrafo, quando o autor escreve “É o título que dou para o tema abordado". Além disso, o caráter pessoal permeia todo o texto, como pode ser observado nos fragmentos: “[...] nossos problemas sociais"; "Para nós excluídos da sociedade [...]” e "Para mim a solução é a concientização $[\ldots] "$.

Uma linguagem repleta de pessoalidade não é aceita pela modalidade escrita dissertativo-argumentativa. Assim, a falta de adequação do texto à situação sociocomunicativa faz com que ele esteja em desequilíbrio ao conceito de situacionalidade.

A oralidade também está presente, principalmente, quando o autor utiliza termos rudes, e até de baixo calão, para discorrer sobre o tema proposto, o que pode ser exemplificado através de um trecho do primeiro parágrafo: “[...] e o pobre que se dane" e “[...] mas estão interessados se eu matei alguém famoso da mídia”. Desse modo, mais uma vez a linguagem mostra-se inadequada ao contexto de produção em que está inserida.

O texto, no geral, apresenta gravíssimas falhas no que concerne à MR1 (continuidade). No primeiro parágrafo, percebe-se que há utilização do recurso de retomada textual "eles", em alguns momentos elíptico, sem o autor explicitar a quem está se referindo. É inevitável a pergunta: Eles quem? A pronominalização seria aceitável desde que tivesse sido explicitado quem "eles" está substituindo. O referente deveria ter sido apresentado ao leitor, para, depois, de forma anafórica, ser utilizado o pronome em seu lugar. Verifica-se, portanto, discordância com a MR1 (continuidade) no que diz respeito à substituição gramatical.

Há redundância quando o autor afirma "[...] é assim todos os dias de domingo à domingo". Se ocorre todos os dias, a expressão "de domingo a domingo" não seria necessária, visto que prejudica a progressão do texto (MR2), por ser redundante, não acrescentando ao texto nenhuma informação nova.

Falta em todo o texto consistência aos argumentos, que são apresentados de maneira superficial, baseados no senso comum e não em situações factíveis, visto que o redator não exemplifica de forma clara situações concretas, as quais confeririam plausibilidade à redação.

A MR4 (articulação) é utilizada de forma precária e, muitas vezes, não está presente no texto. Em alguns momentos, o leitor se vê em uma sequência de frases desconexas, as quais seriam minimizadas se houvesse o uso de conectivos. 
A conclusão fornecida ao final do texto é sem fundamentação, mostrando a total falta de conhecimento do autor pelo tema, visto que não apresentou nenhuma solução eficaz para a resolução do problema.

\section{7-5}

\section{Liberdade de expressão com verdade}

Lutamos, por muito tempo, pelo direito a expressão. Hoje os meios de expressão nos corrompem, alienam e infringem o direito a privacidade. Por fim, lutamos contra o mau uso da expressão e pela verdada na imprensa brasileira.

Apesar da liberdade de imprensa alcançada com o fim da ditadura, o povo brasileiro permanece corrompido pelos meios de comunicação. Vivemos a mercê o sensacionalismo obtidos através das imagens de pobreza e denuncia transmitidas sem nenhum pudor pela televisão. Recebemos informações tendenciosas de grupos partidários que nos alienam quanto a situação do pais. Sem falar no grande comercio que se tornou os meios de comunicação.

Mesmo diante do conhecimento e bom senso das pessoas que trabalham com a comunicação no pais e das tentativas de se criar organizações que contratassem os descasos cometidos pela imprensa, nada de efetivo foi feito. Sem duvida, o controle da inprensa é uma decisão polêmica que pode representar o regresso a uma ditadura nas comunicações.

Dessa forma, apesar dos grandes dificuldades em se estabelecer mecanismo, eficases no controle da inprensa, e preciso que medidas energicas sejam tomadas. A transformação do observatório da imprensa à categoria de orgão civil e governamental de modo a punir os que violassem o direito do cidadão à privacidade e ao exercício das suas atitudes, a criação dos direitos o deveres da imprensa e a minimização da influência político-partidário e capitalista nos meios de comunicação.

\section{ANÁLISE}

O autor demonstra conhecimento da estrutura dissertativa, conseguindo construir suas etapas (introdução/ desenvolvimento/ conclusão) com desenvoltura.

No primeiro parágrafo, percebe-se que o emissor utiliza o termo "meios de expressão" para se referir aos meios de comunicação de massa, como televisão e rádio. Entretanto, a tentativa de substituição não foi bem-sucedida, uma vez que a palavra "expressão" é muito 
mais abrangente, por abarcar todos os processos comunicativos que utilizam as linguagens verbal e não-verbal. Assim, a tentativa de substituição (MR1-continuidade) não foi realizada de maneira adequada.

Ainda no primeiro parágrafo, há o conectivo "por fim”, o qual não está em um lugar adequado. $\mathrm{O}$ uso desse recurso coesivo faria mais sentido se usado no último parágrafo da redação, visto que tal conector tem a função justamente de incluir uma ideia conclusiva. No primeiro parágrafo, ainda é feita a introdução, sendo que o uso dos conectores "assim", "dessa forma" e "desse modo" teria sido mais coerente que "por fim". Por isso, através dessa falha, é possível afirmar que a MR4 (articulação) não aconteceu de forma efetiva nesse trecho.

A linguagem utilizada é repleta de pessoalidade, característica não aceita pela modalidade escrita dissertativo-argumentativa, como pode ser observado através dos verbos "Lutamos", "Vivemos", "Recebemos". Assim, a falta de adequação do texto à situação sociocomunicativa deixa-o em desequilíbrio com o conceito de situacionalidade.

Assim sendo, verificamos que o texto tem um padrão de coerência razoável, mas peca por fugir parcialmente ao tema, uma vez que se foca nos abusos cometidos pela mídia. Além disso, apresenta desvios às metarregras postuladas por Charolles.

\section{7-2}

Através dos mais distintos meios de comunicação deixamos que a mídia nos tornem totalmente escravos e dependentes dela. A câmera, muitas vezes, invade a privacidade de muitos, não respeitando e desmoralizando a imagem e honra de pessoas. Enfim, precisamos agir de acordo com a lei, na qual todos possuem direitos a indenização por danos morais.

No Brasil, a televisão é um dos principais meios de comunicação, cujas decisões são direcionadas aos seus representantes. A TV, o rádio, causam a alienação no ser humano. Principalmente os de classe baixa, são os que mais sofrem abusos desses meios sem receberam o minimo de respeito, e sem poder reagir sofrem invasões em sua vida privada.

A imprensa, composta de jornalistas e empresas de comunicação, faz sempre do seu telespectador um objeto, usufruindo até o seu limite. O jornalismo necessita de organização e responsabilidade para que a mídia possa agir de maneira ativa, mas sem prejudicar o indivíduo.

Somos livres para obter expressão cultural, científica, e não devemos deixar que a imprensa camufle tudo isso. A mídia tem sua determinada importância, e o nosso dever é 
saber agir, quando ela quer nos comandar. Para se garantir a liberdade de informação é necessário que todos percebam o quanto falta respeito entre os seres humanos.

\section{ANÁLISE}

Há redundância no primeiro parágrafo quando o autor afirma: "Através dos mais distintos meios de comunicação deixamos que a mídia nos tornem totalmente escravos [...]". Os dois termos são sinônimos, o que mostra o uso da MR1 (continuidade). Entretanto, esse recurso foi utilizado de forma equivocada, visto que prejudica a progressão do texto (MR2) por ser redundante e não acrescentar ao texto nenhuma informação nova.

A linguagem utilizada é repleta de pessoalidade, como pode ser observado através dos verbos "deixamos" "precisamos" "somos". Assim, a falta de adequação do texto à situação sociocomunicativa faz com que ele esteja em desequilíbrio ao conceito de situacionalidade.

De modo geral, existe falta de progressividade (MR2), revelada, principalmente, pela carência de organização textual, não havendo, dessa maneira, equilíbrio entre continuidade temática e progressão semântica.

Em alguns momentos, o leitor se vê em uma sequência de frases desconexas, o que pode ser exemplificado pelo excerto: "No Brasil, a televisão é um dos principais meios de comunicação, cujas decisões são direcionadas aos seus representantes. A TV, o rádio, causam a alienação no ser humano”. Nesse trecho não é possível reconhecer ordenação de causa-consequência entre os argumentos expostos pelo produtor da redação. $\mathrm{O}$ autor não deixa explícita a relação entre uma frase e outra. Por isso, a progressão do texto é prejudicada, também, pela falta de conectores (MR4-articulação), os quais estabeleceriam ligação entre os parágrafos e entrelaçariam os argumentos.

A superficialidade das informações denuncia a falta de conhecimento do autor sobre o assunto e sua incapacidade em articular argumentos. Afirmações como: "Através dos mais distintos meios de comunicação deixamos que a mídia nos tornem totalmente escravos e dependentes dela." expõem apenas ideias genéricas que refletem o senso comum, sendo, portanto, passíveis de questionamento pelo leitor, o que compromete a aceitabilidade do texto.

Em vários momentos, há lacunas textuais que interferem da compreensão da mensagem que se deseja transmitir. Essas lacunas estão relacionadas à MR1 (continuidade) em momentos em que são utilizados recursos de retomada textual, mas não é exposto o referente, impossibilitando o leitor de fazer recuperação deste. Exemplos: no primeiro parágrafo: "A câmera, muitas vezes, invade a privacidade de muitos [...]" e no terceiro 
parágrafo: “O jornalismo necessita de organização e responsabilidade para que a mídia possa agir de maneira ativa, mas sem prejudicar o indivíduo.”. Não há como saber a quem se refere "muitos" nem a qual termo "indivíduo" se relaciona.

A conclusão fornecida ao final do texto é sem fundamentação, mostrando a total falta de conhecimento do autor sobre o tema, visto que não apresentou nenhuma solução eficaz para a resolução do problema.

0395571-0

\section{A mídia contribui?}

A mídia está cada vez mais banalizada. Os meios de comunicação exibem o que é mais atrativo e "interessante" e muitas vezes de modo apelativo acabam sendo imorais. Contribuem portanto negativamente para a formação da população.

O meio de comunicação mais utilizado é a televisão. A televisão é o meio que mais atrai o povo. Objetivando elevados ibopes, a televisão tornou-se um meio banalizado. Programas e jornais que exibem a violência são freqüentes. Brigas familiares, confusão, escâdalos, violência e sexo são "produtos" que despertam a curiosidade do telespectador. A televisão está perdendo valores éticos e a cultura está desaparecendo.

O povo assiste a televisão, ouve rádio, acessa a internet como se fosse uma tarefa e uma obrigação do dia-a-dia. Isso provoca uma alienação nas pessoas, que são fortemente influenciadas por esse e outros meios de comunicação. Crianças e adolescentes são os maiores alvos da mídia. Novelas, progrmas e até desenhos animados induzem eles ao modismo, a violência e ao sexo. Programas educativos são raros e os que ainda restam, não são de interesse desses telespectadores.

A mídia está perdendo o limite. Os meios de comunicação man- [mandam] e alienam a cabeça das pessoas. Ao mesmo tempo que a televisão perde os valores morais o ibope aumenta, exatamente o que é interessante para eles. E para o povo o que é interessante? Au[audiência] elevada, valores rebaixados, essa é a realidade.

\section{ANÁLISE}

Esse texto chama a atenção pela constante reiteração do termo "televisão", começando por afirmações absolutamente desprovidas de informatividade, como "A televisão é o meio 
que mais atrai o povo". O exagero na repetição de palavras e ideias fere o requisito de progressão (MR2), incorrendo no que Charolles chamou de "circularidade" do discurso.

Na realidade, em todo o texto, a MR1 (continuidade) é mal desenvolvida, visto que há uma excessiva repetição lexical que ocorre com os vocábulos "programas" "violência", "povo", revelando o vocabulário limitado do autor, que não consegue utilizar outros recursos de substituição, como os sinônimos, por exemplo.

Percebe-se que há falta de progressividade (MR2), revelada, principalmente, pela carência de organização textual, não havendo, dessa maneira, equilíbrio entre continuidade temática e progressão semântica. Nesse texto, não é possível reconhecer ordenação de causaconsequência entre os argumentos expostos pelo produtor da redação.

Há repetição de ideias que denuncia o pouco conhecimento do redator sobre o tema proposto, fato que prejudica toda a argumentatividade do texto, por não possuir poder persuasivo, uma vez que não se mostra capaz de articular argumentos, só de repeti-los. A exemplo disso, temos, no primeiro parágrafo: "A mídia está cada vez mais banalizada."; no segundo parágrafo: “a televisão tornou-se um meio banalizado”; no primeiro parágrafo: “[...] muitas vezes de modo apelativo acabam sendo imorais [...]” e no quarto parágrafo: "[...] a televisão perde os valores morais".

Falta em todo o texto consistência aos argumentos, que são apresentados de maneira superficial, baseados no senso comum. A MR4 (articulação) é utilizada de forma precária e muitas vezes não está presente no texto. Em alguns momentos, o leitor se vê em uma sequência de frases desconexas, as quais seriam minimizadas se houvesse o uso de conectivos.

No quarto parágrafo, percebe-se que há utilização do recurso de retomada textual "eles", sem o autor explicitar a quem está se referindo. É inevitável a pergunta: Eles quem? A pronominalização seria aceitável desde que tivesse sido explicitado quem "eles" está substituindo. O referente deveria ter sido apresentado ao leitor, para depois, de forma anafórica, ser utilizado o pronome em seu lugar. Verifica-se, desse modo, discordância com a MR1 (continuidade), no que diz respeito à substituição gramatical.

No último parágrafo, que deveria ser destinado à conclusão do texto, o emissor não expõe nenhuma solução para a problemática proposta. Não há posicionamento crítico, nem fundamentação. $\mathrm{O}$ que se vê é uma pergunta retórica, vaga de sentido e incoerente ao contexto, o que leva ao total distanciamento do que exige um texto dissertativo, no qual é essencial a argumentação e criticidade. 


\section{2-4}

\section{Como garantir a liberdade de informação e evitar abusos nos meios de comunicação?}

Com base na vida real, a comunicação vem ultrapassando barreiras e chegando até em nossas casas de um jeito distorcido.

Será realmente eu iremos ter privacidade, sem que sejamos estrelas em um rádio ou programas policiais. As pessoas estão cansadas de assistir na e carentes.

Há regras leis que proibem a imprensa de invadir a intimidade e a vida privada das pessoas, assegurando indenizações morais e materias. Mas não a como assegurar que essas pessoas irá ser indenizadas pelo baixo índice de conhecimento cultural e ética.

Os programas sensacionalistas, deveriam redigir e apresentar as informações de uma forma moralista e honesta, sem redicularizar os cidadães.

\section{ANÁLISE}

O autor desconhece a estrutura dissertativa, pois desenvolve a redação sem organização, não possuindo delimitação, articulação (MR4), nem continuidade (MR1) entre as partes integrantes: introdução, desenvolvimento e conclusão. Desconhece, também, a distinção entre o que é título e o que é tema, visto que transcreveu a proposta no lugar destinado ao título da redação.

Logo no início do primeiro parágrafo, percebe-se que o emissor utiliza o termo “comunicação" para se referir aos meios de comunicação de massa, como televisão e rádio. Entretanto, nota-se que a tentativa de substituição não foi bem-sucedida, uma vez que a palavra "comunicação" é muito mais abrangente, por abarcar todos os processos comunicativos que utilizam as linguagens verbal e não-verbal. Assim, a tentativa de substituição (MR1-continuidade) não foi realizada de maneira adequada.

Percebe-se, em todo o texto, que há falta de progressividade (MR2), revelada principalmente pela carência de organização textual, não havendo, dessa maneira, equilíbrio entre continuidade temática e progressão semântica. Nesse texto, não é possível reconhecer ordenação de causa-consequência entre os argumentos expostos pelo produtor da redação.

No pequeno parágrafo destinado à conclusão, a proposta que o autor faz não possui qualquer fundamento, mais uma vez corroborando a falta de conhecimento do autor sobre o assunto. 
Com base na análise, nota-se que o produtor dessa redação falhou ao manifestar sua opinião e ao construir os argumentos, os quais se deram de forma insatisfatória. Tudo isso culminou em uma total falta de estrutura textual e de respeito à MR4 (articulação), nos âmbitos da coesão e da coerência.

\section{6-7}

\section{Como garantir a liberdade de informação e evitar abusos}

bem garantir a liberdade de informação e evitar abusos, são hoje uma preocupação de toda a sociedade, pois gostariamos muito de além de termos liberdade de expressão, que exista também o respeito, a honestidade e principalmente a umanização, o amor ao próximo, o direito do cidadão, que esta informação nos chegue passando credibilidade, prazer e respeito. No qual todos nos merecemos. Temos que nos unir para lutar contra esses abusos. Como? Anunciando, botando a boca no trombone, enfim mostrando a nossa insatisfação, procurando faz a nossa parte como cidadão. Lutando sempre pela preservação da nossa privacidade. Liberdade sim, mais com honestidade.

\section{ANÁLISE}

O aspecto visual da redação já demonstra a falta de conhecimento do autor pela estrutura dissertativa, visto que não há paragrafação e o que se vê é apenas um bloco contínuo de palavras.

A redação inteira apresenta desorganização e desprovimento de recursos coesivos (MR4-articulação), fatores que levam ao comprometimento de sua linearidade e coerência. Sua pequena extensão e a superficialidade dos argumentos denunciam o conhecimento limitado do emissor sobre o assunto.

Há argumentos sem fundamentação, os quais podem ser facilmente questionados pelo leitor, comprometendo a aceitabilidade do texto, uma vez que o leitor pode refutar as ideias propostas pelo redator.

Percebe-se, em todo texto, que há falta de progressividade (MR2), revelada principalmente pela carência de organização textual, não existindo, dessa maneira, equilíbrio entre continuidade temática e progressão semântica. Nesse texto, não é possível reconhecer ordenação de causa-consequência entre os argumentos expostos pelo produtor da redação. 
No fragmento: “[...] que esta informação nos chegue passando credibilidade [...]”, percebe-se que há utilização do recurso de retomada textual "esta", sem o autor explicitar a quem está se referindo. A pronominalização seria aceitável desde que tivesse sido explicitado quem o pronome "esta" está substituindo. O referente deveria ter sido apresentado ao leitor, para depois, de forma anafórica, ser utilizado o pronome em seu lugar. Verifica-se, portanto, discordância à MR1 (continuidade), no que diz respeito à substituição gramatical.

Com relação à linguagem utilizada, verifica-se a presença de oralidade, que pode ser observada no trecho "[...] botando a boca no trombone [...]", elemento que não é aceito pela modalidade escrita dissertativo-argumentativa. Assim, a falta de adequação do texto à situação sociocomunicativa causa desequilíbrio ao conceito de situacionalidade.

Ainda com relação à linguagem, percebe-se que o caráter utilizado é de nível pessoal, fato corroborado pela presença de verbos conjugados na primeira pessoa do plural "gostaríamos", "termos", "merecemos" e "temos" e pronomes possessivos "nossa".

Falta em todo o texto a boa utilização dos recursos coesivos, sendo necessárias adequações às MR1 (continuidade), MR2 (progressão), MR3 (não-contradição) e MR4 (articulação).

Em suma, esse texto apresenta graves problemas de coesão e de coerência, conforme as metarregras postuladas por Charolles, os quais influenciaram diretamente na estruturação precária e deficiente do conteúdo.

\section{6-1}

Atualmente a imprensa não se enporta com oque chega ao povo. Ha um proceço de visar somente o lucro.

Os programas estão cada vez piores com suas programações envolvendo violência e outras coisas como o sexo.

A audiência desses programas vem crescendo, oque faz com que a programação não se altere e continui esse massacre mental.

Os jornais so falam de desastres que levam a morte de milhares de pessoas, de corrupção dos políticos e outras coisas.

A programação vem se encaminhando para um parametro onde não se sabe onde vamos chegar.

O que deve ser fato é colocar um limite de notícias e de programas. 
Promover programas culturais e jornais especiais onde a noticia ou reportagem ruim não vinge [vingue].

O mundo tem que passa por um grade proceso.

\begin{abstract}
ANÁLISE
De uma maneira global, notamos de imediato que o produtor desse texto não consegue expressar satisfatoriamente sua opinião, formando uma precária articulação e organização de suas ideias (MR4-articulação). Também não há articulação entre o texto e o tema proposto.

$\mathrm{O}$ autor aparenta desconhecer a estrutura dissertativa, pois discorre em um grande número de parágrafos muito curtos, oito no total, o que deixa a argumentação comprometida, uma vez que não é possível desenvolvê-la com profundidade e consistência.

A redação inteira apresenta falta de organização e desprovimento de recursos coesivos (MR4-articulação), fatores que prejudicam sua linearidade e coerência. A superficialidade dos argumentos denuncia o conhecimento limitado do emissor sobre o assunto. Há argumentos sem fundamentação, os quais podem ser facilmente questionados pelo leitor, como a afirmação: "O que deve ser fato é colocar um limite de notícias e de programas", como se isso resolvesse o problema, visto que diminuir os programas existentes não eliminaria os abusos cometidos pela mídia. Comentários desse tipo comprometem a aceitabilidade do texto, uma vez que o leitor pode refutar essas ideias propostas pelo redator.

Há repetição lexical ("programação”, “programas”), o que mostra o mau uso da MR1 (continuidade). No caso desse texto, o ideal seria utilizar os recursos de substituição através de sinônimos e pronomes.

De modo geral, existe falta de progressividade (MR2), revelada, principalmente, pela carência de organização textual, não havendo, dessa maneira, equilíbrio entre continuidade temática e progressão semântica. Nesse texto, não é possível reconhecer ordenação de causaconsequência entre os argumentos expostos pelo produtor da redação.

Em alguns momentos, o emissor deixa lacunas textuais, não explicando, por exemplo, o significado de "massacre mental", impossibilitando, assim, a compreensão total da mensagem. Além disso, há outros trechos que são muito vagos e genéricos, tais como: no último parágrafo: "O mundo tem que passa por um grade proceso"; e no quinto parágrafo: "A programação vem se encaminhando para um parametro onde não se sabe onde vamos chegar.”
\end{abstract}


Argumentos desse tipo não contribuem para atribuir ao texto criticidade e poder de persuasão. Não trazem nada de novo ao leitor, não conferindo, dessa forma, informatividade à dissertação.

\section{8-5}

No Brasil não temos liberdade de informação, os acontecimentos se realizam e a imprensa vem rápido para o local fazer sua diligência, aproveitam e ainda comenta notícias que não tem nada haver no boletim do jornal.

Eles chegar para fazer suas reportagens mais quem sobra é quem não tem nada haver com isso, são os pobres miseráveis. Os reporteres não tem nenhum respeito pelas pessoas que entrevistam. Já na televisão e no rádio, os dois são parecidos, o que da em um o outro já comenta a mesma notícia. A policia vem rondando os bairros e atraem os jornalistas para alguns acontecimentos que aparecem, e de repente chega a imprensa que ninguém sabe quem chamou, porque eles estão lá para seu queridíssimo trabalho.

$\mathrm{Na}$ televisão passam notícias sem necessidades que acharia que não tinha porque passar aquela noticia na televisão.

\footnotetext{
ANÁLISE

Após a leitura da redação acima, é possível afirmar que seu produtor apresenta dificuldades em desenvolver a estrutura de um texto dissertativo, visto que não produz suas etapas com eficiência (introdução, desenvolvimento e conclusão).

Há reiteração de palavras e ideias, o que mostra o vocabulário restrito do emissor e a falta de conhecimento a respeito do tema. Essa repetição fere o requisito de progressão (MR2), incorrendo ao que Charolles chamou de "circularidade" do discurso. A exemplo disso temos, no primeiro parágrafo: "notícias que não tem nada haver [...]" e no segundo parágrafo: “quem não tem nada haver [...]”.

De maneira geral, existe falta de progressividade (MR2), revelada principalmente pela carência de organização textual, não havendo, dessa maneira, equilíbrio entre continuidade temática e progressão semântica. Nesse texto, não é possível reconhecer ordenação de causaconsequência entre os argumentos expostos pelo produtor da redação. A progressão do texto é
} 
prejudicada pela falta de conectores (MR4-articulação), os quais estabeleceriam ligação entre os parágrafos e entrelaçariam os argumentos.

No último parágrafo encontra-se o trecho que está mais comprometido no que diz respeito à coerência: "Na televisão passam notícias sem necessidades que acharia que não tinha porque passar aquela noticia na televisão.". Constata-se que a redundância deixa obscura a mensagem que o autor deseja transmitir, sendo um comentário totalmente vago de significação. Não há contribuição argumentativa, ou seja, não apresenta informatividade.

A mais grave das infrações acontece quando o autor não segue a MR3 (nãocontradição), o que deixa o texto totalmente incoerente. No primeiro parágrafo, afirma-se: "No Brasil não temos liberdade de informação", o que é negado logo em seguida, ao escrever que "os acontecimentos se realizam e a imprensa vem rápido para o local”. Uma vez que a imprensa chega rapidamente ao local, presume-se que ela queira transmitir a notícia ao receptor, não o privando de informações. Por isso, a forma como está no texto leva o leitor a pensar que a mídia é livre para informar qualquer notícia que possui. A falta de clareza argumentativa e as contradições encontradas diminuem a aceitabilidade do texto, uma vez que o leitor refuta as ideias propostas pelo redator.

Falta em todo o texto boa utilização dos recursos coesivos, sendo necessária uma adequação às MR1 (continuidade), MR2 (progressão), MR3 (não-contradição) e MR4 (articulação).

Em suma, esse texto apresenta graves problemas de coesão e de coerência, conforme as metarregras postuladas por Charolles, os quais influenciaram diretamente na estruturação precária e deficiente do conteúdo. Assim, o tema proposto não foi desenvolvido conscientemente.

\section{9-0}

O profissional do meio de comunicação deve fazer o seu serviço com clareza e exatidão. Alguns jornalistas quando estão em busca de um fato, não respeitam as propriedades alheias e provocam varias invasões nas casa em busca de notícias.

Os jornalistas devem ter clareza nos artigos que eles publicam, onde este artigo não venha ferir a dignidade da pessoa referida. Quer seja uma pessoa umilde, quer seja uma pessoa com o poder aquisitivo mais elevado. É preciso um decreto de lei que deixe todos os jornalistas com liberdade plena de expressão. 
Além disso, temos assistido, com certa preocupação alguns jornalistas que para passar as notícias em exclusividade, invade as residências alheias. Sem preocupar-se ao menos com o que possa acontecer com os proprietários. Com o surgimento de uma nova lei já existente de mil novecentos e oitenta e oito, certamente alguns profissionais do meio de comunicação passaria a trabalhar corretamente.

Em virtude disso, os profissionais da comunicação, devam ter responsabilidade ao publicar uma matéria. É preciso também que eles tenham o direito de expressar os seus pensamentos sem represárias.

\section{ANÁLISE}

O redator faz bom uso de conectores, tais como: "além disso", "em virtude disso", "também" e "quer seja", mas o texto, de uma forma geral, ainda é carente de mais recursos coesivos que possam estabelecer conexão entre os argumentos (MR4-articulação)

A mais grave das infrações acontece quando o autor não segue a MR3 (nãocontradição), o que deixa o texto bastante incoerente. No segundo e quarto parágrafos, o autor faz as afirmações: "É preciso um decreto de lei que deixe todos os jornalistas com liberdade plena de expressão" e "É preciso também que eles tenham o direito de expressar os seus pensamentos sem represárias.", respectivamente, mas contradiz a ideia no decorrer do texto como pode ser visto nos trechos: "Alguns jornalistas quando estão em busca de um fato, não respeitam as propriedades alheias e provocam varias invasões nas casa em busca de notícias" e "Os jornalistas devem ter clareza nos artigos que eles publicam, onde este artigo não venha ferir a dignidade da pessoa referida".

Assim, o texto torna-se confuso e desconexo, pois afirma que os jornalistas devem ter liberdade de expressão, mas só expõe ao leitor aspectos negativos do profissional em questão. A falta de clareza argumentativa e as contradições encontradas diminuem a aceitabilidade do texto, uma vez que o leitor refuta as ideias propostas pelo redator.

Há repetição de palavras ("jornalista", "pessoa"), o que contradiz a MR1 (continuidade), sendo necessária adequação através de sinônimos ou pronomes, para que se tenha um texto mais coeso.

Os argumentos apresentados são redundantes. O autor não faz acréscimos semânticos, não soma novas ideias, não faz inferências ao que já foi informado, como pode ser verificado nos trechos: “[...] Alguns jornalistas [...] provocam varias invasões nas casa em busca de notícias”; “[...] alguns jornalistas que para passar as notícias em exclusividade, invade as 
residências alheias”. Essa análise mostra que o texto distancia-se do que propõe a MR2 (progressão) e o conceito de informatividade postulado por Beaugrand \& Dressler.

Em síntese, há necessidade de adequação a todas as metarregras propostas por Charolles.

\section{0-1}

Com um política onde o tema seja a liberdade de se expressar independentemente do canal de televisão, jornal, revista e rádio, as pessoais mais humildes da população tenha conhecimento e facilidades de chegar ate lá.

As televisões, jornais e revistas tem mostrado e mostram ate hoje pornográfias para aumentar os níveis de ouvintes e leitores, mas nada tem feito para que se melhore os niveis da falta de cultura mostrada por esses meios de comunicação.

A internet rede mundial de computadores tem nos mostrado o que não deveriam mostrar que é abuso de crianças e adolecentes, mais se no Brasil tivesse, uma política que não só predece negros, indios e miseráveis concerteza a cultura dos leitores e ouvintes mudace muito e eles por sua vez não iriam busca os canais de pronográfias mais sim a cultura a informação que é extremamente importante no crescimento do Brasil no cenári mundial.

\section{ANÁLISE}

Com base na leitura da redação acima, é possível afirmar que seu produtor apresenta dificuldades em desenvolver a estrutura de um texto dissertativo, visto que não produz suas etapas com eficiência (introdução, desenvolvimento e conclusão).

No primeiro parágrafo, percebe-se que há utilização do recurso de retomada textual "lá", sem o autor explicitar a qual termo está se referindo. É inevitável a pergunta: Chegar lá, onde? O uso desse elemento seria aceitável desde que o referente fosse apresentado ao leitor, para depois, de forma anafórica, ser utilizado o advérbio em seu lugar. Verifica-se, portanto, discordância com a MR1 (continuidade), no que diz respeito à substituição gramatical.

Ocorrem reiterações de vocábulos em vários momentos, com destaque para os verbos "ter" e "mostrar", fatores que denunciam o vocabulário restrito do emissor e a falta de conhecimento a respeito do tema. O emissor realiza, desse modo, o uso desequilibrado da 
MR1 (continuidade), no que se refere à repetição, não aproveitando a oportunidade para fazer a substituição do termo através de sinônimos, por exemplo.

A substituição lexical por um termo hiperônimo também eliminaria a enumeração "televisões, jornais e revistas" repetida no texto.

Falta em toda a produção consistência aos argumentos que deveriam ser explorados com clareza e concretude, pois, assim, confeririam plausibilidade à redação. A MR4 (articulação) é utilizada de forma precária e, muitas vezes, não está presente no texto.

De maneira geral, existe falta de progressividade (MR2), revelada principalmente pela carência de organização textual, não havendo, dessa maneira, equilíbrio entre continuidade temática e progressão semântica. Em alguns momentos, o leitor se vê em uma sequência de frases desconexas, o que pode ser exemplificado pelo excerto:

A internet rede mundial de computadores tem nos mostrado o que não deveriam mostrar que é abuso de crianças e adolecentes, mais se no Brasil tivesse, uma política que não só predece negros, indios e miseráveis concerteza a cultura dos leitores e ouvintes mudace [...].

Nesse trecho, não é possível reconhecer ordenação de causa-consequência entre os argumentos expostos pelo produtor da redação.

$\mathrm{O}$ autor não deixa explícita a relação entre o abuso infantil e o fato de negros e miseráveis serem presos. Por isso, a progressão do texto é prejudicada, também, pela falta de conectores (MR4-articulação), os quais estabeleceriam ligação entre os parágrafos e entrelaçariam os argumentos.

Através da análise, percebe-se que o produtor dessa redação falhou ao manifestar sua opinião e ao construir os argumentos, os quais se deram de forma insatisfatória. Tudo isso culminou em uma total falta de organização textual e respeito à MR4 (articulação).

\section{2-8}

\section{Como garantir a liberdade de informação e evitar abusos nos meios de comunicação?}

Um chefe de edição mais competente, que tivesse uma equipe só para verificar se as notícias tem fundamento.

O repórter ao chegar à qual for o meio de comunicação deveria ter uma equipe responsável para apurar os fatos depois passaria para o chefe de edição, só então sendo aprovada deveria ser publicada. Os problemas que custumamos ver e ouvir de algumas 
pessoas processarem um reporter ou o meio de comunicação o qual foi publicado a notícia é justamente por não ter uma fiscalização mais eficaz na notícia.

As vezes um reporter ver ou alguém fala que viu uma celebridade c/ um amigio (a) já motivo para uma noticia falsa, alguns chegam até publicar que aquela celebridade foi vista (o) com o namorado em um determinado lugar.

Para que o trabalho seja qualificado é necessário que esta equipe trabalhe junta todo o tempo até porque podem trocar opiniões, sujestões para à noticia chegar a sociedade com mais clareza e sem mentiras.

\section{ANÁLISE}

O autor não apresenta conhecimento da estrutura dissertativa, uma vez que não reconhece o tema como proposta para o desenvolvimento de seu texto e sim o considera uma simples pergunta, fato que pode ser verificado no primeiro parágrafo.

Não há introdução ao tema. Além disso, as etapas referentes ao desenvolvimento e à conclusão não são realizadas com propriedade.

A linguagem utilizada apresenta desvios à norma culta. $\mathrm{O}$ autor até faz abreviação de uma palavra ("c/" no terceiro parágrafo) o que não está adequado ao contexto de produção em que o texto está inserido, configurando, portanto, um desacordo no quesito situacionalidade.

Ocorrem repetições de vocábulos em vários momentos: "repórter". "notícia", "equipe". Isso evidencia o vocabulário limitado do autor que, de maneira desequilibrada, fez uso da MR1, no que se refere à repetição e não aproveitou a oportunidade para fazer a substituição dos termos.

Em alguns momentos, são perceptíveis falhas referentes às MR2 (progressão) e MR4 (articulação).

No último parágrafo, utilizando "esta equipe", o emissor tenta fazer a retomada do termo "equipe", utilizado nos dois primeiros parágrafos. Entretanto, fica confuso para o leitor, pois através da distância não é possível fazer a referência ao termo. O redator deveria ter deixado explícito, novamente, o referente no último parágrafo. Assim, constata-se o mau uso da MR1 (continuidade).

De uma maneira geral, faltam pontos de vista mais elaborados que se relacionam ao real objetivo do tema. 


\section{9-2}

$\mathrm{Na}$ sociedade atualmente um dos temas mais abordados e sobre os maléficios e benéficios que a tv, rádios etc... trazem para dentro de nossas casas quando os mesmos muitas vezes não respeitam e não questionam cada fato com responsabilidade.

Quando se trata de ter liberdade de informação por meios da comunicação, nós muitas vezes nos censuramos para obter certos tipos de informação, mas sabemos que é muito importante ter a liberdade para nos manter sempre informados do que se passa no mundo atualmente, para enriquecer nossos conhecimentos mesmo sabendo que ás vezes os meios de comunicação não são cautelosos e criativo ao transmitir mensagens através de fatos invioláveis. No jornal a tarde de Salvador do dia 22.08.04, houve um fato onde à imprensa não se intimidou ao falar de uma mulher que levava (um carregador de celular e 50gr de maconha) dentro de seu ânus para seu parceiro em um presídio, é muito constragedor a imprensa expôr um ser humano de tal forma como foi vista.

Apesar de tudo, existem pontos positivos, como programas educativos, revista educativa que dão liberdade de expressão a sociedade, sem ter que ver fatos perversos e também mórbidas, podemos adquirir informações por meios de comunicação procurando saber do que se trata cada fato, para que assim não ocorra posteriormente risco de violação e casos desagradáveis para nossa sociedade.

\section{ANÁLISE}

Com base na leitura da redação acima, é possível afirmar que seu produtor apresenta dificuldades em desenvolver a estrutura de um texto dissertativo, visto que não produz suas etapas com eficiência (introdução, desenvolvimento e conclusão).

Ocorrem repetições de palavras no decorrer do texto: “comunicação/fatos/informação/sociedade", o que evidencia o vocabulário limitado do autor que de maneira desequilibrada fez uso da MR1, no que se refere à repetição, e não aproveitou a oportunidade para fazer a substituição do termo.

A linguagem utilizada apresenta desvios à norma culta e pessoalidade ("nós", “nossos[as]"). O autor faz abreviação de uma palavra ("gr" no terceiro parágrafo), causando inadequação ao contexto de produção em que o texto está inserido, configurando, portanto, um desacordo no quesito situacionalidade. 
Ao fornecer o exemplo retirado de um jornal de Salvador, o produtor demonstrou capacidade de realizar relação entre seu conhecimento de mundo e o tema proposto, tentando realizar conexão entre eles (MR4), o que contribuiria para a argumentatividade do texto e aumentaria sua informatividade. Entretanto, o autor não fornece maiores detalhes ao leitor, o qual não percebe a relevância do exemplo no texto. $\mathrm{O}$ autor escreve: “[...] é muito constragedor a imprensa expôr um ser humano de tal forma como foi vista", mas, que forma foi essa? O leitor não viu a reportagem para saber. Falta o referente para que se possa fazer a retomada dele no texto. Assim, a exemplificação feita não foi eficiente para a argumentatividade da dissertação e ainda infringiu a MR1 (continuidade).

\section{5-4}

\section{Ética e Lei}

Não se pode escrever uma lei contra a liberdade da emprensa. Impor leis ao jornalismo destrói a democracia. Porém antes dos romanos formularem o primeiro código de conduta civil que se têm notícias na humanidade, regia-se um regime de leis que derivava dos costumes, leis que se chamava censuetodinário. Essas leis são os alicerces para a ética; conjunto de regras morais que rege qual quer sociedade.

Calar a vez de um jornalista por ter ideais políticos divergentes a do governo ou da classe da classe da burguesia é querer acabar com a liberdade de expressão. Sem uma imprensa ativa, interagindo na sociedade fica difícil desfrutar de informações importantes sobre a política ou sobre a sociedade. Ao cortar tal direito o país perde o valor democrático e passa a ser um regime ditatorial, por mais que não haja más intenções nas notícias divulgadas.

A única forma de coibir os desmandos de más jornalistas que divulgam reportagens ou editoriais em busca da audiência ou desestabilizar o governo é a ética. Esse conjunto de regras feitas por quem mais conhece da impressa, o jornalista, podem inibir a circulação de falsas notícias e vetar colunistas que ousam usar do seu poder de persoassão para fins de seus próprios interesses.

Não se deve criar leis, mas sim um orgão de ética que julge com rigor qualquer tipo de irregularidade e que esse próprio orgão com autonomia tenha a responsabilidade de punir infratores. E notícias como a do nosso Presidente bebendo em uma festa particular não seja mais veiculada a mídia. 


\section{ANÁLISE}

O que mais chama a atenção nesse texto dissertativo são seus argumentos contraditórios, o que deixa a redação bastante incoerente. Esse fato é corroborado pela nãoconvergência dos trechos: "Calar a vez de um jornalista por ter ideais políticos divergentes a do governo ou da classe da classe da burguesia é querer acabar com a liberdade de expressão"; "A única forma de coibir os desmandos de más jornalistas que divulgam reportagens ou editoriais em busca da audiência ou desestabilizar o governo [...]” e “[...] notícias como a do nosso Presidente bebendo em uma festa particular não seja mais veiculada a mídia."

Com base nisso, contatamos uma infração à MR3 (não-contradição).

Há, também, constante reiteração do termo "ética”. O exagero na repetição de palavras e ideias fere o requisito de progressão (MR2), incorrendo no que Charolles chamou de "circularidade" do discurso.

Na realidade, em todo o texto, a MR1 (continuidade) é mal desenvolvida, visto que há uma excessiva repetição lexical que ocorre com os vocábulos "leis", "sociedade" e “imprensa”. Isso revela o vocabulário limitado do autor, que não consegue utilizar outros recursos de substituição, como os sinônimos, por exemplo.

Há repetição de ideias que denuncia o pouco conhecimento do redator sobre o tema proposto, fato que prejudica toda a argumentatividade do texto, por não possuir poder persuasivo, uma vez que não se mostra capaz de articular argumentos, só de repeti-los:

"Não se pode escrever uma lei contra a liberdade da emprensa."

"Não se deve criar leis.".

"Impor leis ao jornalismo destrói a democracia.".

“Sem uma imprensa ativa [...] o país perde o valor democrático.”.

“Calar a vez de um jornalista [...] é querer acabar com a liberdade de expressão.

Em suma, o texto necessita de adequação no que diz respeito, principalmente, à MR3 (não-contradição) e MR1 (continuidade), visando clareza na exposição de argumentos e persuasão do leitor, o que aumentaria sua aceitabilidade. 


\section{7-0}

\section{Como garantir a liberdade de informação e evitar abusos nos meios de comunicação?}

Hoje em dia com a abundância de meios de comunicações está mas fácil para as pessoas ter acesso as informações, é claro que alguns tem preferências no que vão ler, assistir ou ouvir. Em decorrência disso os redatores ou os jornalistas, não se limitão passar para o público, eles querem audiência, nos casos dos redatores de revistas eles querem vender cada vez mais não importa o tipo de notícia.

No entanto os publicadores das revistas as vezes acabam sendo prejudicados e até processados por passar informacões que nunca ocorreram ou seja falsas informacões. Todos tem a liberdade de se informar de se comunicar agora é claro que tem que haver limites, se não souber se limitar haverá grandes consequências.

Em virtudes dos fatos mencionados à cima caberia a seguinte pergunta, quais são os limites da comunicação.

\section{ANÁLISE}

O redator revela desconhecimento da estrutura dissertativa até pela confusão que fez entre tema e título. A pequena extensão do texto e a superficialidade dos argumentos denunciam o conhecimento limitado do emissor sobre o assunto.

O tema também não foi abordado em sua totalidade, pois o autor focou-se na ganância da mídia e não discorreu sobre como garantir a liberdade de informação, o que mostra a falta de conexão entre a proposta temática e o texto, sendo desrespeitada a MR4 (articulação).

Não há uma continuidade adequada (MR1), uma vez que há repetição lexical (informações, limites, eles). Há, também, trechos redundantes que comprometem a progressão do texto (MR2). No segundo parágrafo, por exemplo, o autor escreve: "No entanto os publicadores das revistas as vezes acabam sendo prejudicados e até processados por passar informacões que nunca ocorreram ou seja falsas informacões". Toda essa reiteração interfere na argumentatividade que não convence o leitor pela falta de embasamento e profundidade dos comentários apresentados.

O último parágrafo, que deveria ser destinado à conclusão do texto, não expõe nenhuma solução para a problemática proposta. Não há posicionamento crítico nem fundamentação. O que se vê é uma pergunta sem resposta, vaga de sentido e incoerente ao 
contexto, o que leva ao total distanciamento do que se exige de um texto dissertativo, no qual é essencial a argumentação e criticidade.

Assim, é possível afirmar que a infração às metarregras postuladas por Charolles repercutem na estruturação deficiente do conteúdo, não possibilitando que o mote da proposta tenha sido desenvolvido com consciência e serenidade.

\section{4-7}

Pode afirmar de que a emprensa não oferese nenhuma privacidade para os assuntos abordados.

A imprensa é muito sencasionatista em materia de escandalos, pois um só comentario é o ponto inicial para uma materia. Os grandes jornalistas que tem uma grande carreira hoje já passaram por muitos inconvenientes na sociedade.

Podemos notar que os jornais não respeitam os seus leitores, porque a maior parte das materias escritas há sempre um pouco de mentira dando ao leitor informações que não correspondem realmente aos fatos.

$\mathrm{Na}$ tv anunciam invasões, mortes, desastres acontecimentos que choquem os telespectadores que estam recedendo estas noticias, mas não espeitam os entrevistados coagendo-os para que eles degam apenas oque o jornalisque pressisa para imprecionar a quem esta acistindo ou tendo que ler estas nodicias.

Com todos estes aspequetos pode-se afirmar que nem todos os meios de enformação de jornais tato escrito quanto, acistido não são conpletamente verdadeira quanto esta sendo escludas.

\footnotetext{
ANÁLISE

De maneira global, percebe-se de imediato que o produtor desse texto não consegue expressar satisfatoriamente sua opinião, formando uma precária articulação e organização de suas ideias (MR4-articulação). Além disso, não há articulação entre o texto e o tema proposto, pois o emissor foca-se nos abusos cometidos pela imprensa e não discorre sobre a liberdade de expressão.

A redação inteira apresenta falta de organização e desprovimento de recursos coesivos (MR4-articulação), fatores que prejudicam sua linearidade e coerência.
} 
A superficialidade dos argumentos denuncia o conhecimento limitado do emissor sobre o assunto. Há inserção de ideias sem fundamentação, as quais podem ser facilmente questionadas pelo leitor, como na afirmação: "Podemos notar que os jornais não respeitam os seus leitores, porque a maior parte das materias escritas há sempre um pouco de mentira dando ao leitor informações que não correspondem realmente aos fatos”. Comentários desse tipo comprometem a aceitabilidade do texto, uma vez que o leitor pode refutar as ideias propostas pelo redator.

Há repetição lexical ("imprensa”, "jornalista”, "leitor", verbo "respeitar"), o que mostra o mau uso da MR1 (continuidade). No caso desse texto, o ideal seria utilizar os recursos de substituição através de sinônimos e pronomes.

De maneira geral, existe falta de progressividade (MR2), revelada principalmente pela carência de organização textual, não havendo, desse modo, equilíbrio entre continuidade temática e progressão semântica. Nesse texto, não é possível reconhecer ordenação de causaconsequência entre os argumentos expostos pelo produtor da redação.

Em alguns momentos, o emissor deixa lacunas textuais, como no fragmento: "Pode afirmar de que a emprensa não oferese nenhuma privacidade para os assuntos abordados”, mas o autor não expõe previamente ao leitor quais são esses assuntos, impossibilitando, assim, a compreensão total da mensagem. Não há referente para o termo em destaque, estando em desacordo com a MR1 (continuidade).

Além disso, há outros trechos que são muito vagos de sentido, tais como:

$\mathrm{Na}$ tv anunciam invasões, mortes, desastres acontecimentos que choquem os telespectadores que estam recedendo estas noticias, mas não espeitam os entrevistados coagendo-os para que eles degam apenas oque o jornalisque pressisa para imprecionar a quem esta acistindo ou tendo que ler estas nodicias.

Argumentos desse tipo não garantem criticidade, nem persuasão ao texto, pois não trazem nada de novo ao leitor, deixando de conferir informatividade à dissertação.

\section{1-7}

Como garantir a liberdade de informação e evitar abusos nos meios de comunicação? 
A imprensa mostra várias notícias que para algumas pessoas é um alerta, para tomar bastante cuidado como assalto, morte, sequestro e outras coisas. Ao longo dos anos a televisão ajudou bastante as pessoas, como procurar deseparecido etc.

O problema é que a imprensa critica o pobre, negro que não tem conhecimento, pois quando não tem um bom estudo ele é chamado de analfabeto, por isso quando um cidadão é preso por matar o vizinho por causa de uma briga chama-o de perigoso, com isso eles hulmilha aquela pessoa, critica e ás vezes até ofende.

A imprensa isagera de mais e com isso quanto mais ela criticar a pessoa de baixa renda o mundo nunca vai mudar.

\section{ANÁLISE}

O autor desconhece a estrutura dissertativa, pois desenvolve a redação sem estruturação, não possuindo delimitação, articulação (MR4), nem continuidade (MR1) entre as partes integrantes: introdução, desenvolvimento e conclusão. $\mathrm{O}$ emissor desconhece, também, a distinção entre o que é título e o que é tema, visto que transcreveu a proposta no lugar destinado ao título da redação.

Percebe-se, em todo o texto, a falta de progressividade (MR2), revelada, principalmente, pela carência de organização textual, não havendo, dessa maneira, equilíbrio entre continuidade temática e progressão semântica, como no trecho:

O problema é que a imprensa critica o pobre, negro que não tem conhecimento, pois quando não tem um bom estudo ele é chamado de analfabeto, por isso quando um cidadão é preso por matar o vizinho por causa de uma briga chama-o de perigoso, com isso eles hulmilha aquela pessoa, critica e ás vezes até ofende.

Assim, não é possível reconhecer ordenação de causa-consequência entre os argumentos expostos pelo produtor da redação. As duas ideias ligadas pelo conector "por isso" não são convergentes, ficando o leitor sem saber qual a relação entre elas.

Ocorrem reiterações de vocábulos em vários momentos, com destaque para a palavra "imprensa", fator que denuncia o restrito vocabulário do emissor e a falta de conhecimento a respeito do tema. O emissor realiza, desse modo, o uso desequilibrado da MR1 (continuidade), no que se refere à repetição, e também não aproveita a oportunidade para fazer a substituição do termo através de sinônimos, por exemplo. 
No pequeno parágrafo destinado à conclusão, a ideia exposta pelo autor não possui qualquer fundamento, mais uma vez corroborando a falta de conhecimento do autor sobre o assunto.

0395725-0

\section{Liberdade de comunicação}

Em São Paulo ou em qualquer outro lugar existem crianças, que cheiram cola de sapateiro fumam maconha etc.

Eu acho que os programas de televisão não deveriam mostrarem essas coisas, quer dizer que não mostrem as crianças e só falem o que elas estão fazendo. Porque incentiva outras crianças a fazerem a mesma coisa, aquelas que tem a mente fraca sabe, eu acho isso um abuso, porque falam das crianças com menos de 13 a 15 anos.

Eles deveriam tomar vergonha e tentar ajudar essas crianças, para que servem as campanhas que os governantes fazem é só para mostrar ibope, conserteza, elas tem é que ter liberdade para mostrar o que fazem em instituições, e não mostrarem o que as crianças estão fumando nas ruas, deveriam tira essas crianças das ruas.

Para que serve a criança esperança, essas são as minhas opiniões.

Capital de São Paulo

\section{ANÁLISE}

A linguagem utilizada, em alguns momentos, mostra influência da oralidade, através do uso de gírias: "Porque incentiva outras crianças a fazerem a mesma coisa, aquelas que tem a mente fraca sabe [...]".

A falta de conhecimento sobre o tema proposto culmina em redundância, havendo exaustiva repetição de palavras, como pode ser notado no decorrer do texto com o uso do verbo “mostrar". Essa reiteração leva a infrações às MR1 (continuidade), MR2 (progressão) e MR4 (articulação).

Constata-se, também, um caráter não-impessoal ao longo de todo o texto. Podemos verificar exemplos disso no segundo e quarto parágrafos: “Eu acho que os programas [...]”; “[...] eu acho isso um abuso [...]” e “[...] essas são as minhas opiniões”. A falta de adequação do texto à situação sociocomunicativa faz com que ele esteja em desequilíbrio com o conceito de situacionalidade. 
De maneira geral, faltam à dissertação recursos coesivos de retomada (MR1continuidade) e conectores que estabeleçam ligação entre as frases e os parágrafos (MR4articulação).

Há fuga parcial ao tema, uma vez que o autor se preocupa apenas em discorrer sobre a má influência da televisão, não englobando, assim, o tema em sua totalidade. Faltam pontos de vista mais elaborados, ideias adequadas ao real objetivo do texto e o desenvolvimento de uma conclusão consciente.

\section{1-1}

A imprensa é um orgão que foi criado para nos manter informado sobre os acontecimentos mundiais, com toda a imparcialidade necessária para que nós possamos formar nossas opiniões.

Durante acontecimentos importantes para a história da humanidade como por exemplo a Segunda Guerra Mundial, a imprensa brasileira mostrou-se imcompetente e manipulada, como hoje ainda permanece em muitos aspectos, com raros casos de competência e criatividade. Alguns programas ditos jornalísticos ganham bons horários nas grades de programação com dicas de moda, beleza e culinária, não bastando no turno da manhã possuir quatro programas exatamente iguais, falando sobre os mesmos assuntos, com apresentadoras que parecem mais clones umas das outras que para terem nossa audiência ficam conversando com papagaios, piriquitos, cachorros e até mesmo aparelhos de rádios.

O Brasil é um país que possui uma cultura tão rica e que a falta de criatividade impera, exibindo todos os dias mais e mais programas de fofocas, programas policias apelativo e sem nenhum respeito ao sofrimento do ser humano. O que precisamos é que ao vermos mediocridade, inútilidade, infantilidade e baixessas, desliguemos a tv e vamos ler um livro.

O único modo de acarbamos com a exploração que a televisão faz com os pobres prncipalmente, é selecionar melhor o que assiste e saber que o controle do controle remoto é nosso.

\section{ANÁLISE}

O autor demonstra conhecimento da estrutura dissertativa, conseguindo construir suas etapas (introdução/ desenvolvimento/ conclusão) com desenvoltura. 
A linguagem utilizada em alguns momentos possui um caráter pessoal, como pode ser observado através dos verbos "acabarmos", "vermos", "precisamos". Assim, a falta de adequação do texto à situação sociocomunicativa faz com que ele esteja em desequilíbrio com o conceito de situacionalidade.

A progressividade do texto, MR2, fica comprometida, principalmente, no segundo parágrafo, pois o leitor não compreende a relação entre os argumentos expostos, não conseguindo estabelecer ligação entre a imprensa brasileira na época da Segunda Guerra Mundial e os programas matutinos que estavam no ar em 2004. Percebe-se, dessa maneira, desequilíbrio entre continuidade temática e progressão semântica.

Além disso, a redação apresenta necessidade de adequação à MR4 (articulação), pois em alguns momentos faltam conectores, os quais deixariam a estrutura textual mais coesa e garantiria articulação entre os argumentos propostos.

Assim sendo, verificamos que o texto tem um padrão de coerência razoável, mas peca por fugir quase que totalmente ao tema, uma vez que se foca na qualidade dos programas de televisão e não fornece medidas que combatam os abusos e garantam a liberdade de informação. Além disso, a produção apresenta desvios às metarregras postuladas por Charolles.

\section{5-1}

\section{Como garantir a liberdade de informação e evitar abusos nos meios de comunicação?}

Hoje em dia os meios de comunicação tem tornado cada vez mais abusivos.

Os programas de rádios e tvs não tem investido para uma informação aos seus telespectadores.

O maior responsável pela falta de informação hoje em dia tem entrado nos lares, nos horários onde crianças ao invés de estarem assistindo algo compátivel com a sua cultura tem tornado cada vez pior pois os programas tem investido dando lugar a prostituição infantil, violencia tem tomado lugar fazendo com que a criança, o adolescente viva a sua idade acelerando o indice de prostituição nos lares.

A causa mais comum disso são os programas de finais de tarde as novelas etc...

E como mudar essa situação? 
A saída para que isso se resolva é pararmos de darmos audiência a essa violência. Orientar aos nossos filhos, parentes que esse tipo de informação não leva a ninguém a lugar algum.

Temos que por um fim nisso tudo dar um basta nessa violencia que tem chegado em nossos lares sem pedir licença, a final cada um de nós temos um livre arbítrio.

\begin{abstract}
ANÁLISE
De maneira global, notamos, de imediato, que o produtor desse texto não consegue expressar satisfatoriamente sua opinião, formando uma precária articulação e organização de suas ideias (MR4-articulação).

O autor aparenta desconhecer a estrutura dissertativa. Os parágrafos são muito curtos e em grande número, sete no total, o que deixa a argumentação comprometida, uma vez que não é possível desenvolvê-la com profundidade e consistência.

A linguagem utilizada, em alguns momentos, possui caráter pessoal, como pode ser observado através dos verbos "temos" e "pararmos" e, também, da utilização do pronome "nossos". Assim, a falta de adequação do texto à situação sociocomunicativa faz com que ele esteja em desequilíbrio com o conceito de situacionalidade.

A redação inteira apresenta falta de organização e desprovimento de recursos coesivos (MR4-articulação), fatores que prejudicam sua linearidade e coerência. A superficialidade dos argumentos denuncia o conhecimento limitado do emissor sobre o assunto.

Há presença de ideias sem fundamentação, as quais podem ser facilmente questionadas pelo leitor, como na afirmação: "os programas tem investido dando lugar a prostituição infantil, violencia tem tomado lugar fazendo com que a criança, o adolescente viva a sua idade acelerando o indice de prostituição nos lares”. Comentários desse tipo comprometem a aceitabilidade do texto, uma vez que o leitor pode refutar as ideias propostas pelo redator.

Há repetição lexical ("violência", "prostituição", "programas", verbo “ter"), o que mostra o mau uso da MR1 (continuidade). No caso desse texto, o ideal seria utilizar os recursos de substituição através de sinônimos e pronomes.

De maneira geral, existe falta de progressividade (MR2), revelada principalmente pela carência de organização textual, não havendo, desse modo, equilíbrio entre continuidade temática e progressão semântica. Nesse texto, não é possível reconhecer ordenação de causaconsequência entre os argumentos expostos pelo produtor da redação.
\end{abstract}


Em alguns momentos, o emissor deixa lacunas textuais, fazendo comentários vazios de sentidos e muito genéricos, como em "[...] esse tipo de informação não leva a ninguém a lugar algum”, impossibilitando a compreensão total da mensagem.

Argumentos iguais a esse não atribuem criticidade nem persuasão ao texto, pois não trazem algo de novo ao leitor, deixando de conferir informatividade à dissertação.

\section{8-3}

\section{Como garantir a liberdade de informação e evitar abusos nos meios de comunicação?}

A privacidade das pessoas vem diminuindo cada vez mais, perante a mídia tendo sua vida exposta para a sociedade sem direito de concondância ao fato.

Esse polêmico assunto vem frustando a população ao sentir sua intimidade invadida. Por não serem punidos muitas da vezes publicam noticias adquiridas sem preocupar se com opinioes de muitos. Eles gravando por livre vontade.

Em maioria dos casos acaba criando problemas por comprometer imagem dos cidadões ali presente, prejudicando, atrapalhando sua vida no dia-dia.

Isso ocorre constantemente e causa insatisfação. Ocorre em função da falta de compreensão da Imprensa que não dão espaço ao livre arbítrio dos mesmo. Fazendo que teja conflito entre as famílias.

\section{ANÁLISE}

O autor desconhece a estrutura dissertativa, pois desenvolve a redação sem organização, não possuindo delimitação, articulação (MR4), nem continuidade (MR1) entre as partes integrantes: introdução, desenvolvimento e conclusão.

Presenciamos repetição de ideias que denuncia o pouco conhecimento do redator sobre o tema proposto, fato que prejudica a argumentatividade do texto, por não permitir poder persuasivo, uma vez que não se mostra capaz de articular argumentos, só de repeti-los. A exemplo, temos as frases: "A privacidade das pessoas vem diminuindo cada vez mais, perante a mídia tendo sua vida exposta [...]"; e "Esse polêmico assunto vem frustando a população ao sentir sua intimidade invadida [...]”.

De maneira geral, existe falta de progressividade (MR2), revelada, principalmente, pela carência de organização textual, não havendo, desse modo, equilíbrio entre continuidade 
temática e progressão semântica. Nesse texto, não é possível reconhecer ordenação de causaconsequência entre os argumentos expostos pelo produtor da redação.

No segundo parágrafo, percebe-se que há a utilização do recurso de retomada textual, através do pronome "eles", sem o autor explicitar a quem está se referindo. É inevitável a pergunta: Eles quem? A pronominalização seria aceitável desde que tivesse sido explicitado quem ou o que "eles" está substituindo. O referente deveria ter sido apresentado ao leitor, para depois, de forma anafórica, ser utilizado o pronome em seu lugar. Verifica-se, desse modo, discordância à MR1 (continuidade) no que diz respeito à substituição gramatical. O mesmo caso acontece nas sequências “[...] sem preocupar se com opinioes de muitos” e "[...] por comprometer imagem dos cidadões ali presente", nas quais o autor não apresenta referente para os termos em destaque.

Falta em todo o texto consistência aos argumentos que são apresentados de maneira superficial. A MR4 (articulação) é utilizada de forma precária. Em alguns momentos, o leitor se vê em uma sequência de frases desconexas, as quais seriam minimizadas se houvesse o uso de conectivos.

\section{4-5}

É importante e necessária a atividade da imprensa na sociedade, pois esta, tem como fundamento transmitir informações ligando a população a diversos lugares. A mídia é o meio de entreteinimento mais utilizado, nela estão ligadas diferentes classes sociais, idades e variadas culturas e idéias.

Já que grande parte da população tem um nível de escolaridade baixo, a imprensa transforma isso em espaço para programas apelativos, sensacionalista, achando-se no direito de participar da vida destas pessoas, e faria dos seus problemas ibopes. Essa ação da imprensa contradiz e desrespeita o artigo X da $5^{\text {a }}$ Constituição Federal de 1998: "São invioláveis a intimidade, a vida privada, a honra e a imagem das pessoas, assegurando o direito de indenização pelo dano material ou moral decorrente da sua violação."

A imprensa é a informante universal da população, se esta, justamente abortasse e esclarecesse os telespectadores dos seus direitos, os programas sensacionalistas e policiais sairiam de cena dando lugar à noticiários respeitaveis. Como consequiência disto, acabaria a apelação realizada pela imprensa para eu as pessoas se interessem em saber das muitas perversas histórias que ocorrem com pessoas (pobres) desconhecidas. É necessária uma 
comunhão entre liberdade de expressão e a inviolação de intimidade das pessoas, trazendo assim, uma imprensa a favor da população e dela própria, procurando assim, adquirir pontos na colaboração para o fim da ignorância.

\section{ANÁLISE}

Com base na leitura da redação anterior, é possível afirmar que seu produtor apresenta dificuldades em desenvolver a estrutura de um texto dissertativo, visto que não produz suas etapas com eficiência (introdução, desenvolvimento e conclusão).

De maneira geral, existe falta de progressividade (MR2), revelada, principalmente, pela carência de organização textual, não havendo, desse modo, equilíbrio entre continuidade temática e progressão semântica. Nesse texto, não é possível reconhecer ordenação de causaconsequência entre os argumentos expostos pelo produtor da redação.

Nos segundo parágrafo, o autor se apropria de trechos da Constituição Federal, tentando efetuar um paralelo entre o que é direito e o que realmente acontece. Percebe-se, nesse momento, que há intertextualidade, um dos sete fatores de textualidade propostos por Beaugrand \& Dressler. No entanto, essa superposição de um texto a outro não é realizada de maneira satisfatória, por executá-la de forma confusa e cometer erros ao fazer referência à Constituição, como o ano de publicação e o número do artigo, dados que estavam em um dos textos-base.

No terceiro parágrafo, constata-se infração à MR3 (não-contradição): “A imprensa é a informante universal da população, se esta, justamente abortasse e esclarecesse os telespectadores dos seus direitos". O argumento é totalmente questionável por não apresentar coerência, não deixando claro o que se deve fazer: tirar direitos ou esclarecê-los ao telespectador? Essa falha reduz a credibilidade do texto, o que influencia em sua aceitabilidade pelo leitor.

Encontramos repetição lexical, com destaque para a palavra "imprensa", que é reiterada várias vezes, por isso, nota-se o mau uso da MR1 (continuidade). No caso desse texto, o ideal seria utilizar os recursos de substituição através de sinônimos e pronomes. Além disso, o texto apresenta carência de conectores, os quais possibilitariam o entrelaçamento entre os parágrafos e argumentos. Notamos, igualmente, uma falta de conexão mais efetiva entre o tema e o texto (MR4 - articulação).

Em alguns momentos, o emissor deixa lacunas textuais, fazendo comentários vazios de sentido e muito genéricos, como em: “A imprensa é a informante universal da população 
[...]”. Argumentos iguais a esse não garantem ao texto criticidade nem persuasão, pois não trazem nada de novo ao leitor, não conferindo, dessa forma, informatividade à dissertação.

\section{9-3}

\section{Como garantir a liberdade de informação e evitar abusos nos meios de comunicação}

Garantimos certas informações através de jornais revistas, televisão, radios que nós oferece completo conforto por intimidação aléia. Temos a nossa imprensa que tem a total responsabilidade de nos oferecer grandes informações de diversos tipos, tanto de críticas, drama e outros.

$\mathrm{Na}$ verdade o meio de comunicação compreende a acompanhar a mídia do Brasil tendo os seus representantes, jornalistas, serviços públicos, que compreende os privilégios dos grandes comunicados eventuais específicos em contrapartidas em responsabilidades sociais e seus deveres.

E de muito desempenho a forma para garantirmos a forma de passarmos uma informação levando em conta o que se trata, se ela é verdadeira ou não tem nenhum proveito.

\section{ANÁLISE}

Primeiramente, é necessário destacar a falta de estruturação do texto, tendo em vista que o autor desconhece a organização dissertativa. Não há delimitação, articulação (MR4), nem continuidade (MR1) entre as partes integrantes: introdução, desenvolvimento e conclusão.

A linguagem utilizada, em alguns momentos, possui um caráter pessoal, característica não aceita pela modalidade escrita dissertativo-argumentativa. A exemplo, temos os verbos "garantimos", "temos" e "passarmos" e o uso do pronome "nossa". Assim, a falta de adequação do texto à situação sociocomunicativa deixa-o em desequilíbrio com o conceito de situacionalidade.

Com relação à MR1, encontramos muitas repetições lexicais ("informação", "forma", "verbo", "compreender"), o que mostra o mau uso desse requisito de coerência, pois o ideal seria utilizar os recursos de substituição através de sinônimos e pronomes.

Macroestruturalmente existe falta de progressividade (MR2), revelada, principalmente, pela carência de organização textual, não havendo, dessa maneira, equilíbrio entre 
continuidade temática e progressão semântica. Nesse texto, não é possível reconhecer ordenação de causa-consequência entre os argumentos expostos pelo produtor da redação.

Os parágrafos que estão mais comprometidos são o segundo e o terceiro, os quais trazem trechos ininteligíveis. A falta de organização dos argumentos e a inadequação à estrutura do código escrito prejudicam a compreensão da mensagem que o emissor deseja transmitir, criando, apenas, sequências sem sentido para o leitor.

Essa redação necessita de reestruturação e reescrita, visando a sua adequação, uma vez que infringiu todas as metarregras propostas por Charolles.

\title{
0395809-4
}

\section{Meius de informar}

Garantir não? Como preserva a informação, respeitando as pessoas que precisam deles para está a par do que está acontecendo no mundo, a midia em geral está aos poucos se autoregularizando.

Em $1^{\circ}$ lugar respeitando a se próprio, depois a sua profisão e em $3^{\circ}$ as pessoas que precisam das informações para o dia-a-dia. A comunicação no Brasil é importante para o desenvolvimento dos Brasileiros. Por que a partir de jornais, revistas, livros e TV podemos regularizar e prostestar a liberdade de informação da mídia em geral e também evitar que a imprensa por irresponsabilidade acabe agredindo verbalmente pessoas que está passando por problemas aqui não citados.

A Responsabilidade das empresas de comunicações como também dos jornalistas é está sempre respeitando e cultivando o drama dos cidadões humildes de baixa renda.

As possibilidades de remeter informações básicas mais culturais está realmente trazendo possibilidades das pessoas ter conhecimentos das importancias que o mundo trás.

\begin{abstract}
ANÁLISE
Notamos, de imediato, que o autor desconhece a estrutura dissertativa, pois desenvolve a redação sem organização, deixando esta de possuir articulação (MR4) e continuidade (MR1) entre as partes integrantes: introdução, desenvolvimento e conclusão.

No segundo parágrafo, percebemos que o emissor utiliza o termo "comunicação" para se referir aos meios de comunicação de massa, como televisão e rádio. Entretanto, nota-se que a tentativa de substituição não foi bem-sucedida, uma vez que a palavra "comunicação" é
\end{abstract}


muito mais abrangente, por abarcar todos os processos comunicativos que utilizam as linguagens verbal e não-verbal. Assim, a tentativa de substituição (MR1-continuidade) não foi realizada de maneira adequada.

É perceptível, em todo texto, a falta de progressividade (MR2), revelada, principalmente, pela carência de organização textual, não havendo, dessa maneira, equilíbrio entre continuidade temática e progressão semântica. Nesse texto, não é possível reconhecer ordenação de causa-consequência entre os argumentos expostos pelo produtor da redação.

No pequeno parágrafo destinado à conclusão, a proposta que o autor faz não possui qualquer fundamento, corroborando a falta de conhecimento do autor sobre o assunto.

Em alguns momentos, o emissor deixa lacunas textuais, fazendo comentários vazios e muito genéricos, como em: "A comunicação no Brasil é importante para o desenvolvimento dos Brasileiros". Argumentos iguais a esse não garantem criticidade nem persuasão ao texto.

Com base na análise, nota-se que o produtor dessa redação falhou ao manifestar sua opinião e ao construir os argumentos, os quais se deram de forma insatisfatória. Tudo isso culminou na desorganização textual e desrespeito à MR4 (articulação).

\section{8-3}

A imprensa tem um grande poder na sociedade, porém tem usado esse poder de forma desonesta, visando somente os seus lucros, esquecendo-se que na divulgação de certa reportagem eles incluem o caráter do cidadão. Com isso quem tem mais sofrido é a classe baixa, que tem a sua privacidade invadida.

Alguns programas em busca de audiência tem defraudado o carater de muitos cidadãos, em alguns casos cidadãos esses honestos que por falta de conhecimento caem na armadilha de muitas imprensa.

Elas chegam como grandes invasores, invadem os seus lares sem pedir licença, como se fossem os donos da verdade, como se de fato conhecessem o que se passa na população carente, sendo que o que eles deveriam mostrar é a real situação de pobreza em que essas pessoas vivem, e levarem para elas situações precissas.

Nada mais justo é a punição para esses invasores de lares, pois a reputação de um cidadão é algo que o dinheiro não compra. 
Com base na leitura realizada, é possível afirmar que o autor da redação desconhece a estrutura e características dissertativas. É notável a fuga parcial ao tema, uma vez que a proposta temática não é contemplada em sua totalidade, fato que revela uma infração à MR4 (articulação). O autor aborda os abusos da mídia e não argumenta absolutamente nada sobre como garantir a liberdade de informação.

A argumentação apresenta-se de maneira desorganizada e superficial, pois falta articulação entre as ideias expostas (MR4), revelada pela carência de recursos coesivos. A argumentatividade fica comprometida, visto que as sequências são desconexas e apresentam comentários que não contribuem para o desenvolvimento de um texto crítico e consciente: “[...] em alguns casos cidadãos esses honestos que por falta de conhecimento caem na armadilha de muitas imprensa.”.

A falta de conhecimento sobre o tema proposto culmina na redundância, havendo exaustiva repetição de ideias (e palavras), como pode ser notado no decorrer do texto: "Com isso quem tem mais sofrido é a classe baixa, que tem a sua privacidade invadida" (no primeiro parágrafo); "Elas chegam como grandes invasores, invadem os seus lares sem pedir licença [...]" (no terceiro parágrafo); e "Nada mais justo é a punição para esses invasores de lares [...]" (no quarto parágrafo).

Com base nisso, podemos observar infrações às MR1 (continuidade), MR2 (progressão) e MR4 (articulação).

O vocabulário reduzido acaba favorecendo o aparecimento de repetições lexicais, como as palavras "poder", "invasores", "imprensa", "cidadão(s)". Fato que mostra inadequação à MR1.

Em alguns momentos, o leitor percebe-se em meio a trechos desconexos, sequências confusas que não contribuem para a argumentatividade, não havendo atitude persuasiva por parte do autor. Tomemos como exemplo um trecho do segundo parágrafo: “[...] em alguns casos cidadãos esses honestos que por falta de conhecimento caem na armadilha de muitas imprensa.".

O que seria essa "armadilha"? O leitor fica sem saber o que o emissor quis dizer. A falta de clareza e de fundamentação não possibilita o entendimento da mensagem. A tentativa de uso da MR2 (progressão) acabou por deixar o texto confuso e com lacunas, as quais o receptor não consegue fazer inferências para preenchê-las. É possível afirmar, também, que há discordância com a MR4 (articulação) por apresentar uma ideia que nada se relaciona com a proposta temática. 
A conclusão apresenta-se em um parágrafo muito curto, no qual não há argumentação. Observa-se apenas generalidade no que o autor sugere para acabar com os abusos da mídia, não havendo criticidade. O emissor apenas reproduz uma ideia vaga de significação. Com base nisso, a informatividade desse texto fica bastante comprometida.

\section{9-9}

\section{Como garantir a liberdade de informação e evitar abusos nos meios de comunicações}

Os inúmeros meios de comunicação existentes, ao longo dos tempos veêm se aproveitando de diversos fatos, sejam eles, bons ou ruins tudo para obter prestigios e ibopes. Todo o ser humano independente de idade, classe etnia e outros têm por direito, a informação; sobretudo, informações que não degrida a moral, a cultura e mais deste indíviduo.

A liberdade de informação construtiva tem que ser garantida pelo governo, mesmo que estás informações sejam cruéis aos olhos do homem, entretanto limitar as palavras a serem usadas e as cenas a serem mostrada pois, nunca se sabe quem está do outro lado; pois, programas informativos veêm exibindo cenas e livros e jornais redatando capítulos que comprometem muitas pessoas e vêm deixando tantas outras estarrecidas.

Há várias maneiras de se evitar esses abusos de informações, a primeira providência a ser tomada é criando leis muito mais rigorosas e a segunda é penalizando os que são incorretos para com a massa que necessita de tais meios de comunicação.

Criando tais leis e pondo-as em prática os empresários iriam evitar os abusos com e para o ser humano e se falhasse para com os mesmos pagariam muito caro; perdendo o cargo, o nome e o prestígio.

\footnotetext{
ANÁLISE

Com base na leitura da redação, é possível afirmar que seu produtor apresenta dificuldades em desenvolver a estrutura de um texto dissertativo, visto que não produz suas etapas com eficiência (introdução, desenvolvimento e conclusão).

Encontramos repetição lexical, com destaque para o vocábulo "informação(ões)", o que mostra o mau uso da MR1 (continuidade), sendo que o ideal teria sido utilizar os recursos de substituição, através de sinônimos e pronomes.
} 
No segundo parágrafo há reiteração do conectivo "pois". Embora tenha sido um recurso coesivo positivo, o autor poderia ter realizado a articulação com outro conector de mesmo efeito, como "porque”, "visto que”, evitando, assim, repetição desnecessária.

De modo geral, existe falta de progressividade (MR2), revelada, principalmente, pela carência de organização textual, não havendo, dessa maneira, equilíbrio entre continuidade temática e progressão semântica. Nesse texto, não é possível reconhecer ordenação de causaconsequência entre os argumentos expostos pelo produtor da redação.

Falta em todo o texto consistência aos argumentos, que são apresentados de maneira superficial. A MR4 (articulação) é utilizada de forma precária. Em alguns momentos, o leitor se vê em uma sequência de frases desconexas, as quais seriam minimizadas se houvesse o uso de conectivos.

\section{6-9}

Através dos meios de comunicação são difundidas informações e notícias pelo mundo todo sendo difícil o controle do que é divulgado. Sabe-se do auto poder de persuasão da mídia na vida das pessoas sendo capaz de formar opiniões e julgamento a cerca de determinado fato.

Com o surgimento dos meios de comunicação, hoje é possível saber o que acontece do outro lado do mundo, falar com uma pessoa em Tóquio, estando no Brasil, comprar pela internet.

Infelismente pessoas mal informadas; pouco instruidas são manipuladas constantemente por quem detêm o poder da imprensa. Mostrando para a população somente o que lhe convém o que é de seu interesse que o povo saiba, formando opiniões a eles favoráveis.

Buscar a realização de um trabalho sério, responsável, competente, faz-se necessário visto que com uma população bem informada possa ser capaz de buscar a realização de seus direitos e o bom cumprimento de seus deveres.

\section{ANÁLISE}

Com base na leitura realizada, é possível afirmar que a presente dissertação apresenta fuga parcial ao tema, uma vez que a proposta temática não é contemplada em sua totalidade, 
fato que revela infração à MR4 (articulação). O autor tece comentários sobre os lados positivo e negativo da mídia, mas não discorre sobre como garantir a liberdade de informação.

Faltaram, no texto, argumentos mais aprofundados e coerentes à proposta temática.

O vocabulário reduzido acaba favorecendo o aparecimento de repetições lexicais, como das palavras "meios de comunicação", "pessoa" e "população". Fato que mostra inadequação à MR1 (continuidade).

Na conclusão, observa-se apenas uma sugestão muito genérica, na qual não há criticidade. $\mathrm{O}$ autor apenas reproduz uma ideia muito vaga de significação. Com base nisso, a informatividade do texto fica bastante comprometida.

\section{5-8}

\section{A cidadania e os meios de comunicação}

A televisão juntamente com jornais e revistas tem como objetivo passar informações, mostrar acontecimentos atuais. Sem dúvida a mídia desempenha um papel muito importante na sociedade. Porém, a mídia, tem seu "lado obscuro", pois ela também é vista como um abuso à sociedade, uma invasora da vida privada.

Esse conflito engloba dois importantes direitos do cidadão: o da liberdade de expressão e o da não violação a vida privada e a imagem das pessoas. Neste caso, a mídia, se vê com direito e acaba violando a intimidade, a imagem das pessoas na sociedade.

Para que nenhum direito seja violado, acredita-se que seja necessário uma fiscalização de alguma entidade governamental em todos os setores da emprensa para que as informações mostradas tanto na televisão quanto em revistas e jornais, não ultrapasse um limite a ponto de ir contra aos direitos de cidadania.

\footnotetext{
ANÁLISE

O autor demonstra conhecimento da estrutura dissertativa, conseguindo construir suas etapas (introdução/ desenvolvimento/ conclusão) com desenvoltura.

A linguagem utilizada é impessoal, sendo adequada à modalidade escrita dissertativoargumentativa. Assim, a adequação à situação sociocomunicativa equilibra o texto ao conceito de situacionalidade que postula Beaugrand \& Dressler.
} 
O texto apresenta boa progressividade (MR2), havendo equilíbrio entre continuidade temática e progressão semântica.

Além disso, a redação apresenta adequação à MR4 (articulação), havendo a presença de conectores, os quais deixam a estrutura textual mais coesa e garantem articulação entre os argumentos propostos.

Entretanto, verificamos repetição lexical inadequada, pois o emissor poderia ter utilizado outros recursos de retomada textual, os quais evitariam as repetições dos vocábulos: "mídia", "sociedade", "pessoas", "vida" e "imagem". Tal fato evidencia a falta de revisão que culminou na reiteração de tais palavras.

Assim sendo, verificamos que o texto tem um bom padrão de coerência, expondo os argumentos com clareza ao leitor, apesar de pecar em algumas retomadas, sendo necessárias algumas adequações à MR1 (repetição.)

\section{8-0}

\section{Os abusos nos meios de comunicação}

Sensacionalistas e ambiciosos. Assim podemos caracterizar os meios de comunicação e os rumos que a imprensa brasileira está tomando. Cabe à mídia entreter e informar, preservando a integridade do que é mostrado. Porém o que parece estar ocorrendo é que a única preocupação dos meios de comunicação está voltada para o aumento nos índices de audiência.

Por um lado a mídia está autorizada pela Constituição Federal a fazer uso da liberdade de informação, contando que preserve a vida privada das pessoas. Por outro lado, a tentação de permear de exageros e mentiras o que é exibido se torna maior do que a manutenção da integridade dos meios de comunicação. Afinal, o que dá mais audiência que desastres fatídicos e sofrimento? Está claro que a imprensa faz uso das mais diversas especulações e informações falsas para criar polêmica. Desta maneira é fácil entreter e hipnotizar o público insaciável e assim manipular a opinião da sociedade.

A mídia possui responsabilidades sociais e tem poder de influencia na mentalidade popular. Por isso é de grande importância a fiscalização do que é exibido como produto jornalístico para que assim se possa garantir que a mídia está cumprindo seu papel na sociedade, como formadora de opinião, meio de informação social e de entretenimento. Esta fiscalização deve ser tratada como algo imprescindível na manutenção da qualidade da mídia, 
com pagamento de indenizações e punições efetivas aos que desrrespeitam a imagem das pessoas.

A auto-regulação também deve ser posta em prática, através da conscientização de jornalistas, emissoras e empresas que devem ter sempre em mente suas responsabilidades para com a sociedade. Através destas medidas, é possível manter a liberdade de expressão da imprensa e ao mesmo tempo evitar a degradação da qualidade dos meios de comunicação.

\begin{abstract}
ANÁLISE
O autor demonstra conhecimento da estrutura dissertativa, conseguindo construir as etapas introdução e desenvolvimento com certa desenvoltura. Entretanto, o emissor peca quando constrói a conclusão que se mostra mal localizada dentro do texto e pouco estruturada, finalizando o texto de maneira simplista.

A linguagem utilizada, na maior parte do texto, é impessoal, sendo adequada à modalidade escrita dissertativo-argumentativa. Assim, a adequação do texto à situação sociocomunicativa faz com que ele esteja em equilíbrio ao conceito de situacionalidade.

O texto apresenta boa progressividade (MR2), havendo equilíbrio entre continuidade temática e progressão semântica.

Além disso, a redação apresenta adequação à MR4 (articulação), pois notamos a presença de conectores, os quais deixam a estrutura textual mais coesa e garantem articulação entre os argumentos propostos.

Entretanto, notamos repetições propriamente ditas no decorrer do texto. $\mathrm{O}$ emissor poderia ter utilizado outros recursos de retomada textual, os quais evitariam as repetições dos termos: "mídia", "meios de comunicação", e "sociedade". Tal fato evidencia a falta de revisão, que culminou na reiteração de tais palavras.

Assim sendo, verificamos que o texto tem um bom padrão de coerência, expondo os argumentos com clareza ao leitor, mas peca em algumas retomadas, sendo necessárias adequações à MR1 (repetição), além de necessitar de reestruturação no parágrafo em que efetua a conclusão do texto.
\end{abstract}

\title{
0395883-3
}

\section{Os programas de sensacionalistas do radio}


Os programas de radios e televisão atualmente revela que os cidadões mais afetados com a violência em toda parte da cidade são aqueles levem humildes cujo não tem como se defender das ivasões em suas humildes casas pelos policiais que vão a procura de marginal.

A população são tratados como se fosse um marginal pelos políciais o pior de tudo isso é que quando são denuciados ninguém e punido.

A Imprensa também invadem as casas mais é o trabalho dela porem eles não agride ningem a imprensa procura informações concretas para depois publicar nos jornais e televisão.

No Brasil entre outras organizações existe outros meios de comunicação pois cada um deles tem seu jeito de trabalhar serviços público, com garantia e privilégios.

A mídia Brasileira tem sua meneira de expressar suas notícias mais elaborada e mais confiantes e ect.

\section{ANÁLISE}

Notamos, inicialmente, a presença de fuga parcial ao tema, uma vez que a proposta temática não é contemplada em sua totalidade, fato que revela infração à MR4 (articulação). $\mathrm{O}$ autor não argumenta absolutamente nada sobre como garantir a liberdade de informação.

O redator possui dificuldade em utilizar a norma culta, apresentando sérias falhas no que compete à estruturação formal do texto. Os desvios são tantos que comprometem a compreensão por parte do leitor, pois, muitas vezes, este se percebe em meios a sequências ininteligíveis, como no trecho do quarto parágrafo: "No Brasil entre outras organizações existe outros meios de comunicação pois cada um deles tem seu jeito de trabalhar serviços público, com garantia e privilégios.".

De forma geral, existe falta de progressividade (MR2), revelada, principalmente, pela carência de organização textual, não havendo, dessa maneira, equilíbrio entre continuidade temática e progressão semântica. Nesse texto, não é possível reconhecer ordenação de causaconsequência entre os argumentos expostos pelo produtor da redação.

A argumentação apresenta-se de maneira desorganizada e superficial, e falta articulação entre as ideias expostas (MR4), revelada pela carência de recursos coesivos. A argumentatividade fica comprometida, visto que as sequências textuais apresentam comentários que não contribuem para o desenvolvimento de um texto crítico e consciente.

A falta de conhecimento sobre o tema proposto culmina em redundância, havendo repetição de palavras como "marginal" e "imprensa", como pode ser notado no decorrer do 
texto. Essa reiteração fere a MR1 (continuidade), pois o emissor poderia ter utilizado outros recursos de retomada textual e evitado a repetição.

No último parágrafo, que deveria expor uma conclusão, não há posicionamento crítico por parte do redator nem tentativa de criar uma solução para o problema, uma vez que não indica quais atitudes deveriam ser colocadas em prática.

\section{5-0}

Mídia é a liberdade de expressar fatos históricos ou acontecimentos dentro dos meios de comunicação. No âmbito social que vivemos, a mídia esta presente nos informando através dos meios de comunicação (rádio, tv, jornais, revistas, etc) tudo que acontece no mundo. Procuram buscar fatos interessantes ou não, para deixar o telespectador sempre informado. Embora alguns fatos que a mídia expõe não sejam agradáveis e construtivos, cabe ao telespectador saber destiguir o que é bom para enriquecer conhecimentos e o que é mal para empobrecer. Alguns fatos expostos são carregados de saber e cultura, outros já são suporte para alienação do ser humano.

\section{ANÁLISE}

O aspecto visual da redação já demonstra a falta de conhecimento do autor pela estrutura dissertativa, visto que não há paragrafação. O que se vê é um bloco contínuo de palavras sem delimitação entre introdução, desenvolvimento e conclusão.

O texto inteiro apresenta falta de organização, possuindo carência de recursos coesivos e comprometimento em sua linearidade e coerência.

Houve fuga parcial ao tema, fato que prejudicou a argumentatividade do texto, uma vez que o redator não contemplou a proposta em sua totalidade, o que nos possibilita afirmar que há discordância com a MR4 (articulação).

Em vários momentos, percebemos que o autor inicia uma ideia e não a conclui antes de iniciar outra informação, o que, mais uma vez, mostra a falta de conectores (MR4articulação) na constituição do texto.

Nota-se, também, que não há uma continuidade adequada (MR1), pois as palavras são repetidas automaticamente e a dissertação fica empobrecida de recursos de retomada textual, tais como: sinônimos, pronomes ou advérbios. Tudo isso mostra o léxico limitado do autor, o 
qual também não possui um conhecimento aprofundado do tema, fato confirmado pela superficialidade dos argumentos apresentados.

É nítida, também, a falta de progressividade (MR2), revelada, principalmente, pela carência de organização textual, não havendo, dessa maneira, equilíbrio entre continuidade temática e progressão semântica. Nesse texto, não é possível reconhecer ordenação de causaconsequência entre os argumentos expostos pelo produtor da redação.

Esse texto chama a atenção pela constante reiteração do termo "mídia", começando por afirmações absolutamente desprovidas de informatividade, como: "Mídia é a liberdade de expressar fatos históricos ou acontecimentos dentro dos meios de comunicação”. O exagero na repetição de palavras e ideias fere o requisito de progressão (MR2), incorrendo no que Charolles chamou de "circularidade" do discurso.

Sobre a informatividade, o autor não expõe nenhuma informação relevante, deixando a desejar nesse quesito, pois apenas reproduz ideias muito genéricas, provenientes do senso comum e, portanto, sem fundamentação.

\section{3-1}

O sensacionalismo é um problema de uma falta de ética tamanha nos meios comunicativos. A exploração de notícias fundamentadas em demasias [denúncias] e mentiras ocasiona danos a sociedade. E mesmo tendo seus direitos constitucionalmente assegurados, tais entidades ferem absurdamente os direitos indivíduais.

Constata-se inumeros casos de falsas notícias, visando a desmoralização e audiência. Esses orgãos adentram de maneira abjeta na vida de pessoas morbidamente curiosas. As quais encontra-se em estado de estagnação cultural, decorrente da falta de informações culturais.

O Brasil passa por um período conturbado de consuras e preceguições, garantindo, posteriormente, o direito de livre expreção. Hoje tal direito implica na demasia dos fatos. E afeta diretamente a honra, a moral e a imagem.

Se for necessário uma política de censura para garantir os direitos humanos e a maior coerência nas instituições.

\section{ANÁLISE}


Embora o autor tenha apresentado pouco conhecimento da estrutura dissertativa, efetua uma delimitação entre introdução, argumentação e conclusão. Entretanto, não realiza essas etapas com muita propriedade.

Percebe-se que há falta de progressividade (MR2), revelada, principalmente, pela carência de organização textual, não havendo, dessa maneira, equilíbrio entre continuidade temática e progressão semântica. Nesse texto, não é possível reconhecer ordenação de causaconsequência entre os argumentos expostos pelo produtor da redação.

No segundo parágrafo, encontramos a afirmação: “Esses orgãos adentram de maneira abjeta na vida de pessoas morbidamente curiosas", cuja falta de clareza faz o leitor questionar-se a quem está relacionado o pronome "esses" se não há referente para ele. Com isso, podemos afirmar que o uso da MR1 (continuidade) por substituição se justificaria se a utilização do pronome demonstrativo "esses" fosse feita anaforicamente, ou seja, após a apresentação do referente.

Em alguns momentos, o emissor deixa lacunas textuais, não explicando, por exemplo, o significado de "morbidamente curiosas", impossibilitando, assim, a compreensão total da mensagem. Além disso, há outros trechos que são muito vagos e genéricos de sentido, tais como, no primeiro parágrafo: "O sensacionalismo é um problema de uma falta de ética tamanha nos meios comunicativos" e no segundo parágrafo: "Constata-se inumeros casos de falsas notícias, visando a desmoralização e audiência”. Argumentos desse tipo contribuem para a perda de criticidade e poder de persuasão do texto.

Em vários momentos, percebe-se que o autor inicia uma ideia e não a conclui, demonstrando infrações à MR2 e MR4 no texto.

Por fim, faltam pontos de vista mais elaborados e ideias adequadas ao real objetivo do texto.

\section{4-4}

Garantir a liberdade de informação e evitar abusos dos meios de comunicação é difícil principalmente para as famílias de baixa renda porque na maioria das vezes são analfabetas não conhecem seus direitos.

Eles não sabem nem que existem leis que proibem a invasão da casa de qualquer cidadão se [sem] que tenha uma ordem. A imprensa contribui muito para esse drama das familia baixa renda, quando a policia invade os morros, favelas, a imprensa está sempre filmando tudo sem se informar da situação pronta para divulgar. Na maioria da vezes 
divulgam que a pessoa e traficante, que é bandido quando na verdade os bandido daí ate que venha provar sua inoscência a vida dele toda desestruturada.

No Brasil quem e considerado bandido e quem rouba coisas mínima pra não dexar que os filhos morram de fome. Voltando a falar da imprensa deveria exitir leis que punisse severamente a imprensa marron. $O$ sensacionalista que publica fatos não confirmado ainda para obter pontos no ibope acabam jogando sujo principalmente com a população de baixa renda não existe nenhuma preocupação em relação a imagem as levam anos para construir, mas contudo isso eu ainda acredito que algum dia teremos uma imprensa honesta que nos mostre os fatos como eles acontecem.

\section{ANÁLISE}

Essa dissertação foge quase que totalmente ao tema proposto e apresenta desvios de estruturação formal.

Nota-se, também, que não há continuidade (MR1), pois as palavras são repetidas e o texto fica empobrecido de recursos de retomada textual, tais como: sinônimos, pronomes ou advérbios. Há repetição de palavras, o que denuncia a limitação de vocabulário do produtor do texto, sendo necessária adequação à MR1 e uso dos recursos de substituição. Os vocábulos "bandido", "imprensa" e "baixa renda" são reiterados várias vezes, demonstrando o uso desequilibrado da MR1 (repetição).

A argumentação apresenta-se de maneira desorganizada, pois falta articulação entre as ideias expostas (MR4), revelada pela carência de recursos coesivos. A argumentatividade fica comprometida, visto que as sequências são desconexas e apresentam comentários que não contribuem para o desenvolvimento de um texto crítico e consciente.

Sobre a linguagem, é possível afirmar que há incorporação de elementos da oralidade, os quais prejudicam a argumentação por revelar um teor de informalidade na escrita, como se observa no trecho do segundo parágrafo: "Na maioria da vezes divulgam que a pessoa e traficante, que é bandido quando na verdade os bandido daí ate que venha provar sua inoscência a vida dele toda desestruturada.”.

Em alguns momentos, o emissor deixa lacunas textuais, não explicando, por exemplo, o significado de "imprensa marrom", o que impossibilita a compreensão total da mensagem. Além disso, há outros trechos muito genéricos de sentido, passíveis de questionamento pelo leitor, como no segundo parágrafo: "A imprensa contribui muito para esse drama das familia 
baixa renda, quando a policia invade os morros, favelas, a imprensa está sempre filmando tudo sem se informar da situação pronta para divulgar.”.

Argumentos desse tipo não trazem nada de novo ao leitor, sendo, dessa maneira, apenas reprodutores do senso comum e, por isso, passíveis de refutação, diminuindo a aceitabilidade do texto.

\section{8-4}

\section{Como garantir a liberdade de informação...}

Os veiculos de comunicação não podem violar a imagem das pessoas. A atividade de comunicação é livre, independente de censura ou licença. Parece um contraste?

É preciso uma auto-regulação da midia, uma fiscalização nos meios de comunicação.

Os programas sensacionalistas invadem casas violam a intimidade, a honra e a imagem das pessoas. São casos lastimaveis; familias são expostas as camêras, pessoas são envergonhadas.

Existem leis e elas foram feitas para serem observadas. No artigo $5^{\circ}$ da constituição federal de 1988, tem uma lei que proibe a violação da intimidade, da vida privada, da honra e da imagem das pessoas, assegurando o direito a idenização pelo dano material ou moral decorrente a sua violação. Tem que ser comprida, assim hávera liberdade de informação com privacidade e respeito.

\section{ANÁLISE}

Mais uma vez, notamos fuga parcial ao tema, uma vez que a proposta temática não é contemplada em sua totalidade, fato que revela infração à MR4 (articulação). O autor aborda os abusos da mídia e não argumenta absolutamente nada sobre como garantir a liberdade de informação. Por isso, não há convergência entre título e o que está desenvolvido no texto.

A argumentação apresenta-se de maneira desorganizada, pois falta articulação entre as ideias expostas (MR4), revelada pela carência de recursos coesivos. A argumentatividade fica comprometida, visto que as sequências são desconexas, desprovidas de argumentatividade e apresentam comentários que não contribuem para o desenvolvimento de um texto crítico e consciente. 
No que diz respeito à MR2, podemos afirmar que falta ao texto progressão, devido à desorganização textual. Não há, pois, equilíbrio entre continuidade temática e progressão semântica. Nessa produção, não é possível reconhecer ordenação de causa-consequência entre argumentos expostos pelo produtor.

Há repetição de palavras propriamente ditas, o que denuncia a limitação de vocabulário do produtor do texto, sendo necessário adequação à MR1 (continuidade) e uso dos recursos de substituição. Os vocábulos são reiterados várias vezes, com destaque para o verbo "violar", que aparece em muitos momentos no texto.

A superficialidade das informações denuncia a falta de conhecimento do autor sobre o assunto e sua incapacidade em articular argumentos. Afirmações como: "Os programas sensacionalistas invadem casas violam a intimidade, a honra e a imagem das pessoas" expõem apenas ideias genéricas que refletem o senso comum, sendo, portanto, passíveis de questionamento pelo leitor, o que compromete a aceitabilidade do texto.

No último parágrafo, o autor se apropria de trechos da Constituição Federal. Embora notemos o recurso da intertextualidade, um dos sete fatores de textualidade propostos por Beaugrand \& Dressler, o autor não a utiliza com propriedade por não conseguir articulá-la ao texto, não mostrando a pertinência da citação.

No parágrafo destinado à conclusão, a proposta que o autor faz não possui qualquer fundamento, mostrando, mais uma vez, o senso comum e corroborando a sua falta de conhecimento de mundo e sobre o assunto abordado.

\section{9-7}

A imprensa é o maior veículo de transmissão de informações do século XXI. Ela se utiliza de diversos meios para obter o maior número de dados possíveis do que esses meios de obtenção de informação estão ficando cada vez mais abusivos.

No Brasil, o fim da censura aplicada, em jornais e revistas, significou um grande momento da história nacional: o fim da ditadura militar inicida em 1964. A partir daí, a repressão à liberdade de expressão daria lugar ao culto à informação e à democracia. E a imprensa ganharia proteção na Constituição de 1988, que permite a liberdade intelectual, artística, dentre outros. E o inciso desiguinado para tal, proporcionou um avanço espetacular na comunicação, pois agora todo o mundo fica sabendo quando um cantor tropeça na areia da praia enquanto não inicia a turnê do novo álbum. 
Porém, esse desenvolvimento dos veículos de comunicação (e do capitalismo) vêm fazendo com que os responsáveis pelas notícias (que circundam o planeta a todo instante) elaborem planos mirabolantes para conseguir a informação desejada. Nesses planos estão incluídos: passar pelo muro de três metros; driblar a segurança; desviar dos cães de guarda; pular a janela do primeiro andar e, finalmente, descobrir que o cantor não gosta de comer jiló com beterraba. E mais: fotografa o cantor saindo do chuveiro. Será que é necessário essa invasão de privacidade? Não, pois o cantor não faria nenhuma objeção em dizer que não gosta de jiló.

Com isso, pode-se apurar que não é preciso invadir a liberdade pessoal de ninguém para se conseguir informações. Mas sim de simplicidade, pois não há quem diga que o sorriso da Monalisa é mais bonito que o pôr-do-sol em uma praia.

\footnotetext{
ANÁLISE

O redator demonstra conhecimento da estrutura dissertativa, conseguindo construir as etapas introdução e desenvolvimento com certa desenvoltura. Entretanto, peca quando desenvolve a conclusão, finalizando o texto de maneira simplista.

A linguagem utilizada na maioria do texto é impessoal, sendo adequada à modalidade escrita dissertativo-argumentativa. Assim, a adequação do texto à situação sociocomunicativa o equilibra ao conceito de situacionalidade.

O texto apresenta boa progressividade (MR2), demonstrando equilíbrio entre continuidade temática e progressão semântica.

No segundo parágrafo, o autor se apropria de trechos da Constituição Federal, configurando a intertextualidade, a qual conferiu mais informatividade à dissertação.

No terceiro parágrafo, encontramos algumas afirmações que não são embasadas, sendo, portanto, passíveis de questionamento pelo leitor, o que compromete a aceitabilidade do texto:

Nesses planos estão incluídos: passar pelo muro de três metros; driblar a segurança; desviar dos cães de guarda; pular a janela do primeiro andar e, finalmente, descobrir que o cantor não gosta de comer jiló com beterraba. E mais: fotografa o cantor saindo do chuveiro. Será que é necessário essa invasão de privacidade? Não, pois o cantor não faria nenhuma objeção em dizer que não gosta de jiló.
} 
A redação apresenta, de modo geral, bom uso da MR4 (articulação), havendo a presença de conectores, que deixam a estrutura textual mais coesa e garantem articulação entre os argumentos propostos. Entretanto, no primeiro parágrafo, o redator falha ao selecionar o conectivo, comprometendo a compreensão do trecho: "Ela se utiliza de diversos meios para obter o maior número de dados possíveis do que esses meios de obtenção de informação estão ficando cada vez mais abusivos.", porque, no lugar de "do que", o uso do "pois" teria sido mais adequado.

A presença de repetição lexical automática evidencia infração à MR1. O emissor poderia ter utilizado outros recursos de retomada textual, os quais evitariam repetições de termos como "informação". Tal fato demonstra falta de revisão, que culminou na reiteração de tais palavras.

Em suma, o texto analisado apresenta um bom padrão de coerência, mas peca no aspecto coesivo por infringir, em alguns momentos, as MR1 e MR4.

\section{3-5}

\section{A sociedade contra a imprensa sensacionalista}

Ao dizer que pretendia vir a me tornar uma jornalista no futuro, fui questionada sobre a imprensa atual, se eu estava satisfeita com os meios de comunicação, me expressei da seguinte forma: “Depende, os senhores precisam me dizer sobre que imprensa estamos discutindo". Então me perguntaram: "Existem quantos tipos de imprensa?" eu respondi: "Refiro-me a duas, a imprensa que procura transmitir à sociedade os fatos reais, sem se preocupar com polêmica ou dinheiro, e a segunda, que diriamos a sensacionalista, que busca simplismente a polêmica e o capital, não se importa com respeito e exagera brutalmente com os fatos ocorridos".

Me responderam: "Pois então, estamos falando dessa segunda". Expus minha opinião: "Não, esse tipo de imprensa foge do ideal do real jornalismo, que é apenas manter a população informada, relatar a verdade, o que realmente acontece, e não explorar fatos de maneira desumana, extraindo das pessoas envolvidas dor e desespero, mostrando a todos a que ponto chega a situação humana. Devemos rejeitar esse tipo de mídia, pois ela não nos acrescenta em nada". A pessoa na minha frente perguntou: "Mas como rejeitar? Se o governo fizer algo para desestruturar essa imprensa, irão atacar com as mesmas palavras que não existe liberdade de expressão no Brasil, que a mídia é reprimida porque fala a verdade e etc.”, 
respondi: "Sim, é verdade, mas não são os governantes que têm que fazer algo contra essa imprensa e sim nós, devemos rejeita-los, pois quando não houver quem a escute, ela irá se extinguir. Porém o ser humano se interessa pelos casos que essa mídia relata, se interessa pela vida alheia, e não se satisfaz apenas com o jornalismo de qualidade, e é por isso que essa mídia continua existindo, as pessoas devem selecionar o que lêem e veêm para assim garantir o respeito e a dignidade dos meios de comunicação, dessa forma a real imprensa irá receber os elogios que merece".

\section{ANÁLISE}

Inicialmente, deve-se dizer que o autor não fez uma dissertação, mas uma narração, contrariando totalmente as instruções da prova. Com base nisso, é possível afirmar que o produtor desse texto desconhece a estrutura e características dissertativas. É presente a fuga ao tema, uma vez que a proposta temática não é contemplada em sua totalidade, fato que revela infração à MR4 (articulação). $\mathrm{O}$ autor aborda os abusos da mídia e não argumenta absolutamente nada sobre como garantir a liberdade de informação. Por isso, não há convergência entre título e o que está desenvolvido no texto.

O texto, de uma forma geral, apresenta boa progressividade (MR2), proporcionando equilíbrio entre continuidade temática e progressão semântica. Possui, também, bom uso da MR4 (articulação), havendo presença de conectores, os quais deixam a estrutura textual mais coesa e garantem articulação entre os argumentos propostos.

A presença das repetições lexicais automáticas mostra falta de vocabulário e de criatividade por parte do autor, culminando na infração à MR1. O emissor poderia ter utilizado outros recursos de retomada textual, os quais evitariam as repetições de termos, como "imprensa" e "mídia". Tal fato evidencia a falta de revisão que gera a reiteração de tais palavras.

Em suma, o texto analisado apresenta um bom padrão de coerência, mas peca no aspecto coesivo por infringir, em alguns momentos, as MR1, MR2 e MR4. Além disso, a falta de conhecimento da macroestrutura deve ser evidenciada, pois o autor não consegue fazer a distinção entre "narração" e "dissertação".

\section{8-6}

Como garantir a liberdade de informação e evitar abusos nos meios de comunicação? 
Respeito, essa é a palavra "chave", para se fazer telejornalismo e qualquer outro programa na TV, sem desrespeitar os diretos e a liberdade de cada um, seja ele branco, negro, pobre ou rico. Mas a cada dia que passa é muito comum vermos a falta de respeito da mídia para com, seus telespectadores, principalmente se o mesmo for preto e pobre, eles vão invadindo, sem pedir licença ou permissão de quem direito.

Quando se tem um fato polêmico ou escandaloso a mídia não quer nem saber o que realmente aconteceu, quem está envolvido, enfim, elas só querem o fato seja ele verídico ou falso.

E sem se importar com as pessoas que estão envolvidas e com seus sentimentos eles vão espalnando a notícia e nas maiorias das vezes aumentando o fato, para que isso lhe renda ibope.

Cabe aos telespectadores denúncia esses fatos jornalistas, repórteres e qualquer outra pessoa que abuse da nossa liberdade, sem ter medo de ameaças ou chantagens. Apesar de tudo, precisamos dessa mídia para ficarmos informados, até porque em todas as profissões existe os bons e os maus profissionais.

\section{ANÁLISE}

O autor desconhece a estrutura dissertativa, pois desenvolve a redação sem organização, não possuindo articulação (MR4) nem continuidade (MR1) entre as partes integrantes: introdução, desenvolvimento e conclusão.

Notamos, em todo o texto, a falta de progressividade (MR2), revelada, principalmente, pela desorganização textual, não havendo, dessa maneira, equilíbrio entre continuidade temática e progressão semântica. Nesse texto, não é possível reconhecer ordenação de causaconsequência entre argumentos expostos pelo produtor da redação.

A repetição de vocábulos denuncia a limitação lexical do produtor do texto, sendo necessária adequação à MR1 (continuidade) e do uso dos recursos de substituição, sinônimos e pronomes, por exemplo. Os termos são reiterados várias vezes, com destaque para o substantivo "respeito" e derivados:

Respeito, essa é a palavra “chave”, para se fazer telejornalismo e qualquer outro programa na TV, sem desrespeitar os diretos e a liberdade de cada um, seja ele branco, negro, pobre ou rico. Mas a cada dia que passa é muito comum vermos a falta de respeito da mídia para com, seus telespectadores [...] 
O exagero na repetição de palavras e ideias fere o requisito de progressão (MR2), incorrendo no que Charolles chamou de "circularidade" do discurso.

A superficialidade das informações denuncia a falta de conhecimento de mundo do autor e sua incapacidade em articular argumentos. Afirmações como: "principalmente se o mesmo for preto e pobre, eles vão invadindo, sem pedir licença ou permissão de quem direito" expõem apenas ideias genéricas, e, por que não, preconceituosas, que refletem o senso comum, sendo passíveis de questionamento pelo leitor, o que compromete a aceitabilidade do texto.

Enfim, faltam pontos de vista mais elaborados e ideias adequadas ao real objetivo do texto. Além disso, é necessária a construção de um parágrafo conclusivo que contemple soluções à problemática proposta.

\section{4-5}

Um dos problemas enfrentados por diferentes classes e raças é a "invasão de privacidade".

Muitas vezes acontecem algo que é de extrema particularidade. "Um filho que virou traficante", uma filha que cometeu um "aborto" e assim sucessivamente. É acontecé-los e a imprensa está la para registrar e ganhar ibope. E a privacidade de tal coisa como fica?

Segundo pesquisas "os meios de comunicações não se importa do que as pessoas venham a pensar e sim garantir a sua audiência.

Isso revela que pra se ter uma informação coerente, tem que contribuir com algo.

Os meios de comunicações não se importa com horários, pois transmitem fatos absurdos que estão sendo acompanhados por crianças, logo é preciso acompanhá-las. E ai? Como fica a privacidade?

Segundo pesquisas o setor político está diretamente ligado a esse tipo de abuso da imprensa pois para obter uma informação é preciso está interagindo com os meios de comunicações.

Acha-se uma falta de respeito de qualquer tipo, meios de comunicações que cometem invasão de "privacidade" com qualquer espécie humana.

\section{ANÁLISE}


De uma maneira global, percebemos, de imediato, que o produtor desse texto não consegue expressar satisfatoriamente sua opinião, formando uma precária articulação e organização de suas ideias (MR4-articulação).

O autor aparenta desconhecer a estrutura dissertativa, pois compôs o texto em um grande número de parágrafos curtos, sete no total, o que deixa a argumentação comprometida, uma vez que não é possível desenvolvê-la com profundidade e consistência.

Sobre a linguagem, é possível afirmar que há incorporação de elementos da oralidade, os quais prejudicam a argumentação por revelar um teor de informalidade na escrita, como se observa no trecho do quinto parágrafo: "E ai? Como fica a privacidade?"

Há trechos muito genéricos, passíveis de questionamento pelo leitor, como no terceiro e sexto parágrafos: "Segundo pesquisas os meios de comunicações não se importa do que as pessoas venham a pensar e sim garantir a sua audiência."; e "Segundo pesquisas o setor político está diretamente ligado a esse tipo de abuso da imprensa [...]”.

O autor não fornece detalhes sobre as pesquisas que menciona, ou quais são os institutos responsáveis pela elaboração delas, em que ano foram feitas. Dessa forma, a informação fica muito vaga para o leitor. Argumentos desse tipo não trazem nada de novo, sendo, dessa maneira, apenas reprodutores do senso comum.

$\mathrm{O}$ uso inadequado do requisito da MR1 pode ser verificado através das palavras "imprensa" e "meios de comunicações", pois o ideal seria utilizar os recursos de substituição através de sinônimos e pronomes. Além disso, o emissor também repete ideias: “Um dos problemas enfrentados por diferentes classes e raças é a invasão de privacidade", no primeiro parágrafo; "E a privacidade de tal coisa como fica?, no segundo parágrafo e "Como fica a privacidade?", no quinto parágrafo.

O exagero na repetição de palavras e ideias fere o requisito de progressão (MR2), incorrendo no que Charolles chamou de "circularidade" do discurso.

De modo geral, existe falta de progressividade (MR2), revelada, principalmente, pela carência de organização textual, não havendo, dessa maneira, equilíbrio entre continuidade temática e progressão semântica. Nesse texto, não é possível reconhecer ordenação de causaconsequência entre os argumentos expostos pelo produtor da redação. 
A competição por uma maior audiência entre os meios de comunicação ocasiona, muitas vezes, um abuso por parte da mídia. Os programas sensasionalistas manipulam a informação e violam a intimidade e a vida privada das pessoas.

A guerra de audiência provoca uma deteriorização da notícia para atingir as camadas menos instruídas no Brasil. Jornais populares sensacionalizam a informação, mostrando fotografias de cadáveres na primeira página diariamente. Apresentadores de programas de televisão que são escolarizados e possuem um nível de cultura elevado, comunicam-se com os telespectadores sem concordância gramatical e falando palavrões.

Os jornalistas violam a lei para conseguir uma reportagem. Invadem barracos, filmam sem pedir dicença, fazem de tudo por uma boa tomada. Pessoas públicas como atores e cantores são também prejudicados. Eles são perseguidos por câmeras e ainda são alvos de fofocas e mentiras.

Como garantir a liberdade de informação e evitar abusos nos meios de comunicação? Paises como Suécia e a Grã-Bretanha incentivam a auto-regulação da mídia, tentando resolver o problema da responsabilidade dos jornalistas. Uma outra questão é o fato da mídia estar aonde o povo quer que ela esteja. Se houvesse um maior investimento em educação e cultura, as pessoas não estariam tão interessadas em ver tanto sensacionalismo na imprensa.

\footnotetext{
ANÁLISE

$\mathrm{O}$ autor demonstra conhecimento da estrutura dissertativa, conseguindo construir as etapas introdução e desenvolvimento com certa desenvoltura. Entretanto, falha ao concluir sua produção, finalizando o texto de maneira simplista e desvirtuando a dissertação do real objetivo do tema.

A linguagem utilizada no texto é impessoal, sendo adequada à modalidade escrita. Assim, a adequação do texto à situação sociocomunicativa faz com que ele esteja em equilíbrio com o conceito de situacionalidade do qual postula Beaugrand \& Dressler.

O texto apresenta certa progressividade (MR2), havendo, desta forma, equilíbrio entre continuidade temática e progressão semântica.

A redação apresenta, de modo geral, o recurso da MR4 (articulação), havendo a presença de conectores, os quais deixam a estrutura textual mais coesa e garante articulação entre os argumentos propostos.
} 
Entretanto, há fuga parcial ao tema, uma vez que o autor se foca nos abusos cometidos pela mídia e não discorre sobre o tema proposto. Apenas no último parágrafo, o qual é destinado à conclusão, é que o redator fornece alguma solução para a problemática.

Em suma, o texto analisado apresenta um bom padrão de coerência, mas peca no aspecto coesivo por infringir, em alguns momentos, a MR4 e por não abordar o tema proposto em sua totalidade.

\title{
1132033-8
}

\section{Jornalistas Irresponsáveis}

Os meios de comunicação procuram ser o mais direto possível para evitar abusos com a sociedade em geral. Mas mesmo assim continuam desrespeitando o nosso povo. Por conta disso, o governo já criou uma lei para acabar com esses abusos.

Eles possuem uma determinada liberdade de expressão, mas as vezes eles acabam passando por cima de leis para consegir seus objetivos.

Assim, se suas liberdades não tiver um certo limite, acabam passando por cima de tudo e de todos e, até de normas culturais de um povo sem defeza.

Deveriam ser tomadas mais providências sobre esse caso e especifico.

\begin{abstract}
ANÁLISE
A redação inteira apresenta desorganização, fator que compromete sua linearidade e coerência, revelando, também, o desconhecimento do autor sobre a estrutura dissertativa. Não há articulação (MR4) nem continuidade (MR1) entre as partes integrantes: introdução, desenvolvimento e conclusão.

A pequena extensão do texto e os pequenos parágrafos conferem superficialidade aos argumentos que denunciam o conhecimento limitado do emissor sobre o assunto. $\mathrm{O}$ tema não foi abordado em sua totalidade, pois o autor focou-se nos abusos da mídia e não discorreu sobre como garantir a liberdade de informação.

Não há uma continuidade adequada (MR1), uma vez que há repetição lexical ("abusos", "povo"), fazendo-se necessária a substituição dos termos através de sinônimos e pronomes.
\end{abstract}


Percebe-se em todo o texto, que há falta de progressividade (MR2), revelada, principalmente, pela desorganização textual, não havendo, dessa maneira, equilíbrio entre continuidade temática e progressão semântica. Nessa dissertação, não é possível reconhecer ordenação de causa-consequência entre argumentos expostos pelo produtor da redação.

O último parágrafo, que deveria ser destinado à conclusão do texto, não expõe nenhuma solução para a problemática proposta, pois não há posicionamento crítico nem fundamentação. $O$ que se vê é uma linha escrita, vaga de sentido, apenas expondo um comentário genérico. Esse fator leva ao distanciamento do que se exige de um texto dissertativo, no qual é essencial a argumentação e criticidade.

\section{9-4}

\section{Liberdade não é abuso}

Irresponsabilidade. Futilização da informação. Sensacionalismo. Esse é o lamentável cenário em que o meio de comunicação mais importante no Brasil está vivendo. Num momento em que esse tão informante e influente meio comunicativo deveria passar valores culturais e educacionais a seus telespectadores, a televisão vem apresentando uma intensa desvalorização do seu conteúdo.

Apesar dos televisores terem sido inventados numa tentativa de transmitir programas para atender à responsabilidades sociais e formar uma identidade nacional, o que mais são vistos são programas de um conteúdo pobre, que ao invés de entreter o telespectador, atropelamentos, assaltos e mortes são exemplos da tentativa de entretenimento barato que passam nos programas policiais. Deve-se haver uma maior fiscalização do conteúdo da televisão pelo Observatório da Imprensa.

Embora esse meio comunicativo tenha também como objetivo o divertimento da população que existe, muitos programas abusam com um exagerado sensacionalismo. Tal fato ocorre devido a concorrência desmedida para ver quem estará na frente do IBOPE. Mães chorando por seus filhos desaparecidos, crianças excepcionais pedindo ajuda, filhos fazendo as pazes com pais são exemplos de possíveis armações para prender a atenção do cidadão no canal. Deve-se diminuir a importância do IBOPE para a televisão, na expectativa dessa desleal concorrência terminar.

Portanto, percebe-se que a programação atual não está atendendo a necessidade social

que deveria ter. É necessário ética para os programas pararem com o sensacionalismo, e é de 
vital importância que uma organização como o observatório da Imprensa fiscalize o conteúdo transmitido, para só assim possa haver uma liberdade de informação sem abusos.

\section{ANÁLISE}

Observemos o primeiro parágrafo:

Irresponsabilidade. Futilização da informação. Sensacionalismo. Esse é o lamentável cenário em que o meio de comunicação mais importante no Brasil está vivendo. Num momento em que esse tão informante e influente meio comunicativo deveria passar valores culturais e educacionais a seus telespectadores, a televisão vem apresentando uma intensa desvalorização do seu conteúdo.

A falta de clareza faz com que o leitor se pergunte a quem ou a que o autor estaria se referindo ao fazer mencionar "meio de comunicação mais importante no Brasil", pois não há referente explícito. Com isso, podemos afirmar que o uso da MR1 (continuidade) por substituição se justificaria se a utilização da expressão fosse feita anaforicamente, ou seja, após a apresentação do referente. Desta forma, o termo "televisão" deveria ter sido exposto primeiramente, para, depois, serem apresentados os outros termos correspondentes, situação que não comprometeria a coerência do trecho.

A redação apresenta, de modo geral, bom uso da MR4 (articulação), havendo presença de conectores, os quais deixam a estrutura textual mais coesa e garante articulação entre os argumentos propostos. O texto apresenta boa progressividade (MR2), havendo equilíbrio entre continuidade temática e progressão semântica.

Entretanto, há fuga parcial ao tema, uma vez que o autor se concentra nos abusos cometidos pela mídia e não discorre sobre o tema proposto. Apenas no último parágrafo, o qual é destinado à conclusão, o redator fornece alguma solução para a problemática, mas de forma superficial.

Em síntese, o texto analisado apresenta um bom padrão de coerência, mas peca no aspecto coesivo por infringir, em alguns momentos, a MR1 e por não abordar o tema proposto em sua totalidade.

\section{4-0}

\section{Liberdade no meio de comunicação}


O abuso na comunicação é desnecessário por falta de liberdade culta. Por não ter informações concretas, faz que aja desta forma.

A falta de conhecimentos, argumentos, diálogo, relacionamento, fazendo que à comunicação-se torne impossível de-se demonstrar o quanto são prejudicados.

Dignidade, respeito adquiriu através de comunicações garantindo liberdade de poder expressar idéias, fatos o seu ponto de vista, confiantes que meios de comunicação depende do esforço de vontade, caráter. Esses meios obstáculos não é difícil de conquistar e sim um meio objetivo de adquirir essa meta, que é orgulhosamente mero abuso no meio de comunicação não existe e sim liberdade. É conciderada sim um espetáculo de convivência na comunidade.

\section{ANÁLISE}

O autor possui dificuldade em utilizar a norma culta, apresentando sérias falhas no que compete à estruturação formal do texto, tais como: ortografia, concordância verbal/nominal, acentuação, pontuação. Os desvios são tantos que comprometem a compreensão do texto, pois, muitas vezes, o leitor percebe-se em meio à sequências ininteligíveis, o que pode ser observado no trecho: “[...] O abuso na comunicação é desnecessário por falta de liberdade culta. Por não ter informações concretas, faz que aja desta forma.”.

O redator não apresenta as ideias de maneira clara e erra pela falta de recursos coesivos. O texto é muito carente de estruturação, necessitando de adequações à MR4 (articulação).

Notamos em todo o texto a falta de progressividade (MR2), revelada, principalmente, pela desorganização textual, não havendo, dessa forma, equilíbrio entre continuidade temática e progressão semântica. Nesse texto, não é possível reconhecer ordenação de causaconsequência entre argumentos expostos pelo produtor da redação.

No último parágrafo, onde o autor deveria expor uma conclusão, ele não apresenta ideias, não se posiciona criticamente nem faz a tentativa de criar uma solução para o problema, uma vez que não indica quais atitudes deveriam ser colocadas em prática.

Assim, com base na análise realizada, percebemos a necessidade de reestruturação do texto e adequação a todas as metarregras propostas por Charolles. 


\title{
1132074-5
}

\section{Como garantir a liberdade de informações}

Devemos saber o tipo de informação que transmitimos à alguém, as vezes nos deixamos levar pela influência e não nos preocupamos com o que falamos.

Destacar sempre opiniões com outras pessoas sobre o que fazemos é importante para se ter um desempenho melhor com a vivência no mundo.

Porque a liberdade na hora de se comunicar? Temos que ser livre, usar palavras firme seja pelo telefone, ou falando diretamente.

Para termos um mundo melhor um Brasil com dignidade e um estado para todos que sabem comunicar-se bem.

\begin{abstract}
ANÁLISE
Globalmente, a redação apresenta falta de organização, fator que compromete sua linearidade e coerência, revelando, também, o desconhecimento da estrutura dissertativa pelo autor. Não há articulação (MR4) nem continuidade (MR1) entre as partes integrantes: introdução, desenvolvimento e conclusão.

A pequena extensão do texto e os pequenos parágrafos conferem superficialidade aos argumentos, que denunciam o conhecimento limitado do emissor sobre o assunto. $\mathrm{O}$ tema não foi abordado corretamente, visto que o autor fugiu totalmente da proposta temática.

A superficialidade das informações aponta, novamente, a falta de conhecimento do autor sobre o assunto e sua incapacidade em articular argumentos. Afirmações como: "Para termos um mundo melhor um Brasil com dignidade e um estado para todos que sabem comunicar-se bem." expõem apenas ideias genéricas que refletem o senso comum, sendo, portanto, passíveis de questionamento pelo leitor, o que compromete a aceitabilidade do texto.

A falta de progressão textual é nítida (MR2), o que revela desorganização textual, não havendo, dessa maneira, equilíbrio entre continuidade temática e progressão semântica.

O último parágrafo, que deveria ser destinado à conclusão do texto, não expõe solução para a problemática proposta, pois não há posicionamento crítico nem fundamentação. O que se vê é um parágrafo vago de sentido, que apenas expõe um comentário genérico. Esse fator leva ao total distanciamento do que se exige em um texto dissertativo, no qual é essencial a argumentação e criticidade.
\end{abstract}




\section{7-5}

Liberdade de informação não significa apenas mostrar a desgraça das vidas de certos cidadãos, e as situações humilhantes vividas por eles, mas a população no lugar de programas educativos de jornais, algumas emissoras de televisão e de rádio estão passando programas sensacionalistas, em que o entrevistado tem sua intimidade desrespeitada e não sabe reagir a tal situação. A mídia se utiliza desses recursos em busca de audiência, esquecendo-se do seu real papel, que seria de informar e educar a população.

A solução para esses abusos, é substituir informações supérfluas e sem fundamento, por questões educativas, relacionadas à política, meio ambiente ou saúde.

\section{ANÁLISE}

Toda a redação apresenta falta de organização, fator que compromete sua linearidade e coerência, revelando, também, o desconhecimento do autor pela estrutura dissertativa. Não há delimitação, articulação (MR4), nem continuidade (MR1) entre as partes integrantes: introdução, desenvolvimento e conclusão.

A pequena extensão do texto e sua distribuição em apenas dois parágrafos conferem superficialidade aos argumentos, que denunciam o conhecimento limitado do emissor sobre o assunto. O tema não foi abordado em sua totalidade, pois o autor focou-se nos abusos da mídia e não discorreu sobre como garantir a liberdade de informação.

Não há uma continuidade adequada (MR1), uma vez que há repetição lexical automática de vocábulos: "população", "programas”. Faz-se necessária a substituição dos termos através de sinônimos e pronomes.

Notamos, em todo o texto, que há falta de progressividade (MR2) revelada, mormente, pela desorganização textual, não havendo, dessa forma, equilíbrio entre continuidade temática e progressão semântica. Dificilmente, reconhecemos ordenação de causa-consequência entre os argumentos expostos pelo produtor da redação.

O último parágrafo não expõe solução para a problemática proposta. Desta forma, percebemos que falta ao aluno conhecimento de mundo necessário para a produção de um texto argumentativo de qualidade. 


\section{4-8}

\section{Privacidade versus Liberdade de Expressão}

A liberdade de expressão vêm sendo adquirida ao longo de muitos anos. Atualmente encontra-se no seu auge porém nem sempre é considerada como um aspecto positivo.

Isso deve-se ao fato de que noticiários, jornais e revistas usufruem dessa liberdade desrespeitando a privacidade das pessoas. E nesse contexto, a população mais humilde não questiona essa violação porque não tem informação nem argumentos suficientes para saber de fato o que está acontecendo.

Por esse motivo, o governo que zela pela segurança do povo é obrigado a tomar medidas que por essas informações. Essas restrições caracterizam-se tenção na vida privada alheia.

Em contrapartida vivemos em um país no qualquer forma de expressão artística, científica, de comunicação e intelectual sem censura é um direito de todos. E é através desses tipos de manifestações que chegamos ao desenvolvimento pleno de nossa cultura, economia, educação e integração social.

Na sociedade moderna contemporânea da qual fazemos parte, tanto o governo quanto a imprensa de expressão e privacidade populacional sejam igualmente respeitadas. Sendo assim, teremos cada vez mais progresso e desenvolvimento.

\section{ANÁLISE}

O autor foge parcialmente ao tema proposto por não abordá-lo em sua plenitude, uma vez que discorre sobre os abusos cometidos pela mídia e não se atém ao real objetivo do texto, que é o de propor soluções de como evitar os abusos e garantir a liberdade de expressão.

O redator demonstra conhecimento da estrutura dissertativa, conseguindo construir suas etapas (introdução/ desenvolvimento/ conclusão) com desenvoltura.

De um modo geral, a redação é apresentada de maneira satisfatória e com progressividade. O redator faz bom uso do requisito da MR4 (articulação), utilizando conectores como: "porém", "por esse motivo" e "em contrapartida".

A linguagem utilizada, em alguns momentos, apresenta caráter pessoal. A exemplo, temos os verbos: "vivemos", "chegamos" e "fazemos", os quais possibilitam o desvio à norma culta, que é requisito argumentativo para o desenvolvimento de um texto dissertativo. 
A falta de adequação do texto à situação sociocomunicativa faz com que ele esteja em desequilíbrio com o conceito de situacionalidade.

Assim sendo, verifica-se que o texto tem um padrão de coerência razoável, mas é malsucedido por fugir ao tema, uma vez que enfatiza a qualidade dos programas de televisão e não fornece medidas que combatam os abusos e garantam a liberdade de informação.

\section{9-9}

\section{Manipulação televisiva}

A baixa qualidade dos programas televisivos está vinculada à interesses de grandes empresas que querem vender produtos e manipular a opinião pública. Os telespectadores não têm muita escolha de assistir a bons canais e acabam assistindo a qualquer programa por falta de opção.

Ao invés de colocarem programas educativos, culturais, as emissoras transmitem, em sua maioria, novelas que não acrescentam em nada, ou programas de fofocas, relacionados de baixa renda, que não tem condições financeiras para ir à um cinema ou teatro, é que assiste televisão televisão juntamente com sua família e seus filhos, tornando-os alienados.

A televisão controla o que a população deve assistir, como as pessoas devem agir, suas índoles, como elas devem ser e primordialmente, suas vidas. Invade sua casa, sua vida, sua intimidade. Incita a todos quererem ser famosos e aparecerem, nem que seja por pouco tempo, como são os casos dos "Reality Shows". O prazer de ser famoso e a vontade é muito maior doque a preservação da imagem e da privacidade. É sinônimo de status perante a sociedade, que é hipócrita.

A população não quer saber da miséria do Norte, nem da seca do Nordeste, muito menos do "plano x" que está sendo aprovada em Brasília. É muito melhor assistir a vida e os deslizes dos artistas, a final de contas, o povo não tem defeitos[...] Enquanto houver cervejinha e carnaval, a vida é uma maravilha, porque o resto não é problema.

Falta para o povo esperteza para ver que é manipulado por uma classe alta, dona da maior parte dos meios de comunicação. A população tem que saber escolher o que assiste e impedir o abuso da invasão de privacidade e impor respeito. Impor seus direitos e não se deixar alienar com as informações incompletas e manipuladas. Reivindicar por melhor cultura e programas descentes. 


\begin{abstract}
ANÁLISE
O autor foge parcialmente ao tema proposto por não abordá-lo em sua plenitude, uma vez que discorre sobre a qualidade dos programas televisivos e não se foca no real objetivo do texto, que é propor soluções de como evitar os abusos da mídia e garantir a liberdade de expressão.

$\mathrm{O}$ redator demonstra conhecimento da estrutura dissertativa, conseguindo construir suas etapas (introdução/desenvolvimento/conclusão) com desenvoltura.

A produção textual inicia-se de maneira satisfatória e com progressividade. De um modo geral, o redator faz bom uso da MR4 (articulação), utilizando conectores como: "ao invés de" e "enquanto".

A linguagem utilizada possui, em alguns momentos, influência da oralidade, como podemos verificar no trecho: "Enquanto houver cervejinha e carnaval, a vida é uma maravilha". A falta de adequação do texto à situação sociocomunicativa faz com que ele esteja em desequilíbrio ao conceito de situacionalidade.

Assim sendo, notamos que o texto tem um padrão de coerência razoável, mas falha por fugir ao tema, uma vez que se preocupa com a qualidade dos programas de televisão e não fornece medidas que combatam os abusos e garantam a liberdade de informação.
\end{abstract}

\title{
1132124-5
}

\section{Dignidade do Cidadão ferida pela falta de Ética da Mídia}

Informação, indiscrição, monopolização - atualmente a globalização torna mais essencial em nosso cotidiano, a presença da comunicação. Essa, porém, vem corrompendo todo um ideal de privacidade e principalmente de respeito à vida de cada ser humano, que após um longo período de ditadura militar no Brasil, tem o regresso de ações extintas, pertencentes ao passado.

A necessidade da monopolização da mídia para determinados e limitados grupos de pessoas nos recorda o DIP (Departamento de Imprensa e Propaganda) utilizada por Vargas durante o Estado Novo, para controlar toda a imprensa e, assim, gerenciar as cabeças e as decisões de cada cidadão brasileiro, retirando a liberdade, tanto de expressão quanto de disseminação de opiniões diferentes da época. Mas como garantir a mudança dessa situação? 
De fato há países onde o legislativo já está pondo em pauta e o executivo em prática regulamentações e limites dos passos da mídia e da imprensa, porém só isso não basta. O bom senso e o respeito ao próximo devem estar na cabeça daqueles que tem por missão transmitir informações e não violar "barracões".

Apesar de uma constituição contraditória a respeito do assunto, garantindo total liberdade à imprensa e ao mesmo tempo privacidade à vida de toda a população, não podemos deixar que opiniões independentes sejam formadas a partir de informações obtidas através da invasão de privacidade e, assim, quebra de liberdade de diversos seres humanos, devemos exigir mais das autoridades em relação às rédias sobre a imprensa.

A falta de ética da mídia ao violar a privacidade alheia, fere a dignidade de cada cidadão confiante na democracia e na legislação assim como nas autoridades, cabendo a estes cidadãos lutar pelo direito de liberdade e pelo respeito da imprensa.

\section{ANÁLISE}

O texto apresenta adequação no que se refere à MR1 (continuidade). Apesar de haver repetição lexical, no decorrer da redação, a reiteração não prejudica a argumentação exposta, tendo em vista que os vocábulos garantem a manutenção temática.

O autor foge parcialmente ao tema proposto por não abordá-lo em sua totalidade, uma vez que discorre sobre a qualidade dos programas televisivos e não foca no real objetivo do texto, que é propor soluções de como evitar os abusos da mídia e garantir a liberdade de expressão.

O redator demonstra conhecimento da estrutura dissertativa, conseguindo construir suas etapas (introdução/desenvolvimento/conclusão) com desenvoltura.

A produção textual inicia-se de maneira satisfatória e com progressividade. De um modo geral, o redator faz bom uso da MR4 (articulação), inserindo conectores como: "de fato", "apesar de", "assim como". O texto progride, demonstrando equilíbrio entre continuidade temática e progressão semântica.

Assim sendo, verifica-se que o texto tem um padrão de coerência razoável, mas erra por fugir ao tema e propor uma solução ineficaz.

\section{8-5}

\section{A Liberdade de Informação}


A liberdade de informação na TV tem como objetivo informar aos telespectadores de vários fatos de notícias da vida cotidiana, que mostra o drama desses cidadões na situação em que se vivem.

Mostrando pessoas humildes que aparecem em delegacias como suspeito de algum delito pequeno que se tenha cometido na sua vida familiar ou particular, e deixando a mídia participar desse momento de glória para os seus jornalistas de plantão.

Tentando retira alguma notícia mesmo sendo boa ou ruim que seja do agrado particular do sistema da mídia.

Logo, tentando não evitar algum tipo de abuso na comunicação sem se refletir na vida dos cidadões.

\begin{abstract}
ANÁLISE
A redação inteira apresenta falta de organização, fator que compromete sua linearidade e coerência, revelando, também, o desconhecimento do autor pela estrutura dissertativa. Não há articulação (MR4) nem continuidade (MR1) entre as partes integrantes: introdução, desenvolvimento e conclusão.

Notamos em todo o texto a falta de progressividade (MR2), revelada, mormente, pela desorganização textual. Não há, dessa maneira, equilíbrio entre continuidade temática e progressão semântica.

A pequena extensão do texto não permite que se aprofundem os argumentos, o que denuncia o conhecimento limitado do emissor sobre o assunto.

A superficialidade das informações denuncia, também, a falta de conhecimento de mundo do autor e sua incapacidade em articular argumentos. Afirmações como: "A liberdade de informação na TV tem como objetivo informar aos telespectadores de vários fatos de notícias da vida cotidiana" expõem apenas ideias genéricas, as quais não contribuem em nada, sendo, desta forma, passíveis de questionamento pelo leitor, o que compromete a aceitabilidade do texto.

O último parágrafo, que deveria ser destinado à conclusão do texto, não expõe solução para a problemática proposta, pois não há posicionamento crítico nem fundamentação. O que se vê é um parágrafo vago de sentido, que apenas expõe um comentário genérico. Esse fator leva ao total distanciamento do que se exige em um texto dissertativo, no qual é essencial a argumentação e criticidade.
\end{abstract}




\section{2-0}

\section{Como garantir a liberdade de informação e evitar abusos nos meios de comunicação?}

Os meios de comunicação, são importantes fontes de informações, mas muitas vezes com informações desnecessárias, subjetivas, moralistas, mas uma "moral" que certos jornalistas não possuem, tornando aquela que era para ser uma informação completa, boa em imoral e suja.

A liberdade de informação tem que ter um certo limite, para não atravessar barreiras existentes, como é o caso dos famosos que tem suas privacidade invadida por esses meios de comunicação. Pessoas que querem vender informações a custo de qualquer preço mesmo que esse esteja altamente ilegal, por conta de ultrapassar limites impostos por cada um.

A melhor forma de não se cometer abusos e garantir liberdade nos meios de comunicação é ter uma equipe profissional de qualidade, que impõe respeito no que está relacionado a profissão. Com bons profissionais as notícias fluem melhores.

\section{ANÁLISE}

Com base na leitura da redação acima, é possível afirmar que seu produtor apresenta dificuldades em desenvolver a estrutura de um texto dissertativo, visto que não produz suas etapas com eficiência (introdução, desenvolvimento e conclusão).

Há repetição lexical, com destaque para o vocábulo "informação(ões)”, o que mostra o mau uso da MR1 (continuidade): "Os meios de comunicação, são importantes fontes de informações, mas muitas vezes com informações desnecessárias, subjetivas, moralistas, mas uma "moral" que certos jornalistas não possuem, tornando aquela que era para ser uma informação completa, boa em imoral e suja." No caso desse texto, o ideal seria utilizar os recursos de substituição através de sinônimos e pronomes.

De modo geral, existe falta de progressividade (MR2), revelada, principalmente, pela carência de organização textual, não havendo, dessa maneira, equilíbrio entre continuidade temática e progressão semântica. Nesse texto, não é possível reconhecer ordenação de causaconsequência entre os argumentos expostos pelo produtor da redação.

Falta em todo o texto consistência aos argumentos, os quais são apresentados de maneira superficial. A MR4 (articulação) é utilizada de forma precária. No primeiro parágrafo, por exemplo, há repetição da conjunção “mas”, que poderia ter sido substituída por 
outros conectivos de mesma equivalência semântica, como "no entanto", "entretanto", “contudo", conferindo ao texto um aspecto mais coeso.

\section{3-6}

Atualmente, as pessoas não possuem liberdade nem em sua própria casa, podem está assistindo TV e derepente um policial entra vascunhando toda a casa e você sem saber o porque. hoje é díficil principalmente para artistas, a garantia de liberdade de informação, pois ele vivem fugindo da mídia e a todo o caso acabam sofrendo abusos dos meios de comunicação como jornais, revistas, TV e rádio.

Esse quadro poder ser mudado, pois os seres humanos teêm direitos de liberdade de informação e ao mesmo tempo de não sofrerem abusos, a Constituição Federal criou uma lei aonde todos os seres humanos são livres e tem o direito de expressão de qualquer atividade intelectual e de comunicação.

há pessoas que acham que se isolar seria o melhor solução dos seus problemas mais hoje não é, o melhor que se pode fazer é enfrentar, sem ter medo.

\section{ANÁLISE}

O redator não apresenta as ideias de maneira clara e falha pela falta de uso de recursos coesivos. O texto é muito carente de estruturação, necessitando de adequações à MR4 (articulação).

Notamos a falta de progressividade (MR2), revelada, principalmente, pela desorganização textual, não havendo, dessa maneira, equilíbrio entre continuidade temática e progressão semântica. Nesse texto, não é possível reconhecer ordenação de causaconsequência entre argumentos expostos pelo produtor da redação.

No primeiro parágrafo notamos o uso da expressão clicherizada "no mundo de hoje", o que denuncia a falta de criatividade do autor ao iniciar sua redação.

De um modo geral, não há continuidade adequada (MR1), uma vez que há repetição lexical automática: "liberdade", “informação", "comunicação", "casa”. Faz-se, pois, necessária a substituição dos termos através de sinônimos e pronomes. 
No último parágrafo, que deveria expor uma conclusão, o autor não apresenta ideias, não se posiciona criticamente, nem faz a tentativa de criar uma solução efetiva para o problema.

\section{6-8}

\section{Como garantir a liberdade de informação e evitar abusos nos meios de comunicação?}

hoje em dia a nossa liberdade de se espressar está em baixa, pois quando queremos falar ou fazer algo verdadeiro que possa mudar o mundo, somos barrados onde estamos. Se quisermos ter voz para que nos ouça temos que lutar com unhas e dentes, com força de vontade.

Nossos meios de comunicação estão uma vergonha, pois, não se faz uma coisa cultural ou Educacional, parece que não querem gente interessada em coisas interessantes como, jornais, documentarios e artes tudo isso faz bem para mente e o corpo.

O que nós devemos fazer e lutar por nossa liberdade de expressão nos jornais ou oral pois temos esse direito de ajudar quem está com a gente e não ficar vendo as coisas mesquinhas e tolas que se veêm e houvem no meio de comunicação.

\footnotetext{
ANÁLISE

O autor desconhece a estrutura dissertativa, pois desenvolve a redação sem seguir uma estrutura predeterminada, deixando de apresentar articulação (MR4) e continuidade (MR1) entre as ideias do texto.

Percebemos, em todo o texto, que há falta de progressividade (MR2), revelada, principalmente, pela desorganização textual, não havendo, dessa maneira, equilíbrio entre continuidade temática e progressão semântica. Nesse texto, não é possível reconhecer ordenação de causa-consequência entre argumentos expostos pelo produtor da redação.

A superficialidade das informações denuncia a falta de conhecimento do autor sobre o assunto e sua incapacidade de articular argumentos. No trecho: “O que nós devemos fazer e lutar por nossa liberdade de expressão nos jornais ou oral pois temos esse direito de ajudar quem está com a gente e não ficar vendo as coisas mesquinhas e tolas que se veêm e houvem no meio de comunicação”, o que o emissor fez foi apenas apresentar ideias genéricas e vagas,
} 
que refletem o senso comum, sendo, portanto, passíveis de questionamento pelo leitor, o que compromete a aceitabilidade do texto.

Sobre a linguagem, é possível afirmar que há incorporação de elementos da oralidade, os quais prejudicam a argumentação por revelarem um teor de informalidade na escrita: "Se quisermos ter voz para que nos ouça temos que lutar com unhas e dentes [...]”. A falta de adequação do texto à situação sociocomunicativa o deixa em desequilíbrio com o conceito de situacionalidade que postula.

Por fim, faltam pontos de vista mais elaborados e ideias adequadas ao real objetivo do texto. Além disso, é necessária a construção de um parágrafo conclusivo que contemple soluções à problemática proposta.

\section{8-1}

\section{Como garantir a liberdade de informação e evitar abusos nos meios de comunicação}

É do conhecimento mundial, que a liberdade de informação é um direito do cidadão e a imprensa deixa as pessoas informadas sobre os fatos mundiais, não obstante os abusos dos meios de comunicação são inevitáveis.

Ao examinarmos as causas, percebemos que a informação é necessária para podermos nos enlançar no mundo globalizado, porém a informação transmitida ao telespectador é moldada, pois os meios de comunicação abusam desta liberdade, conturbando a mente do cidadão, onde só exibem o que lhe é conviniente.

Em conseqüência disso, vemos que a mídia cresce com notícias que possam mexer com o sentimento humano, por conseguinte enclausura o telespectador com temáticas do diaa-dia gerando o âmbito de curiosidade. Ex: Numa tarde de domingo, a família está reunida, a programação da televisão é voltada para os artistas do momento mostrando a vida familiar de cada um deles.

Diante dos argumentos citados acima, o tema em epígrafe alerta a sociedade para a situação da liberdade de informação e como os meios de comunicação devem manipulá-la. Deveríamos ter políticas adequadas com leis rígidas que fiscalizassem esta "liberdade" de informação, desta forma garantiria um excelente desempenho da mídia e sua censura que em contrapartida agradará ao telespectador promovendo uma reflexão sobre a informação transmitida. 


\begin{abstract}
ANÁLISE
O autor demonstra conhecimento da estrutura dissertativa, já que consegue construir as etapas "introdução, desenvolvimento e conclusão" com certa desenvoltura. Entretanto, confundiu o tema com o título, apenas transcrevendo a proposta temática no lugar destinado ao título da redação.

A linguagem utilizada no texto é de caráter pessoal, e pode ser observada pelo uso dos verbos "examinarmos", "podermos" e "vemos", não sendo adequada à modalidade escrita dissertativo-argumentativa. Assim, há um desequilíbrio ao conceito de situacionalidade, devido à inadequação do texto à situação sociocomunicativa.

O texto apresenta boa progressividade (MR2), havendo equilíbrio entre continuidade temática e progressão semântica.

A redação apresenta, globalmente, articulação (MR4), havendo a presença de conectores, os quais deixam a estrutura textual mais coesa e garantem articulação entre os argumentos propostos.

Em suma, o texto analisado apresenta um bom padrão de coerência, mas falha no aspecto coesivo por infringir, em alguns momentos, as MR2 e MR4, como também, por não abordar o tema proposto em sua totalidade.
\end{abstract}

\title{
1132229-9
}

\section{Quem fiscaliza (a imprensa)?}

Hoje em dia todos tem algum complexo com o jornalismo.

Os artistas, atletas, e até pessoas comuns temem disso.

Temos exemplos quando vemos na televisão, às vezes o jornalista exagera um pouco. É fofoca, fuxico etc...

Coisas que pessoas que vivem no mundo de celebridade, tem medo.

Ninguém merece; apesar de quem fica fora desse mundo gosta desse tipo de fuxico, mexerico, mas também existe pessoas que não precisa ser jornalista de grande estilo para exercer essa profissão. É só vigiar de conta própria que já sai um jornalista.

Mais voltando o tema é a profissão dos jornalistas que deixam, assim, tipo descriminado, às vezes eles são um pouco arrogantes e sem escrúpulos. 
Por outro lado é bom, precisamos saber noticias do mundo e de pessoas, geografia, econômica, pra isso eles servem para dar conhecimento para a população.

E assim todos teêm um pouquinho de instrução, da vida; porque na verdade eles exageram na fofoca mais acertam em termos de notícia de informação global.

\begin{abstract}
ANÁLISE
De uma maneira global, percebe-se, de imediato, que o produtor desse texto não consegue expressar satisfatoriamente sua opinião, formando uma precária articulação e organização de suas ideias (MR4-articulação).

$\mathrm{O}$ autor aparenta desconhecer a estrutura dissertativa, pois escreve em um grande número de curtos parágrafos, seis no total, o que deixa a argumentação comprometida, uma vez que não é possível desenvolvê-la com profundidade e consistência.

Sobre a linguagem, é possível afirmar que há incorporação de elementos da oralidade, os quais prejudicam a argumentação por revelar um teor de informalidade à escrita. Observam-se os termos: "fofoca", "fuxico", "mexerico" e o comentário: "E assim todos teêm um pouquinho de instrução, da vida”. Assim, é possível verificar que esse tipo de linguagem não está de acordo com o que permite a linguagem argumentativo-dissertativa.

Há trechos que são muitos genéricos de sentido, passíveis de questionamento pelo leitor, como no primeiro e segundo parágrafos: "Hoje em dia todos tem algum complexo com o jornalismo."; "Os artistas, atletas, e até pessoas comuns temem disso".

Argumentos desse tipo não trazem nada de novo, sendo, dessa maneira, apenas reprodutores do senso comum.

Há repetição lexical do termo "jornalista”, o que mostra o uso inadequado da MR1 (continuidade). No caso desse texto, o ideal seria utilizar os recursos de substituição através de sinônimos e pronomes.

De maneira geral, falta progressividade (MR2) ao texto, o que revela carência de organização textual, não havendo, desse modo, equilíbrio entre continuidade temática e progressão semântica. Nesse texto, não é possível reconhecer ordenação de causaconsequência entre os argumentos expostos pelo produtor da redação.
\end{abstract}

\title{
1132237-3
}

Como garantir a liberdade de informação e evitar abusos nos meios de comunicação? 
Todos nós temos direitos a informação, desde que essa informação, seja transmitida de forma correta, e sem abusos.

Garantiríamos essa liberdade de informação, através de informações limpas, isto é sem inventá-las.

Abusos nos meios comunicações seriam evitados apartir do momento em que todos passem a cobrar mais dos meios de comunicações. É autoridades responsáveis passem a fiscaliza-los e puni-los com multas pesadas e se possível tira-los do ar.

Isso serviria de exemplo para que possíveis abusos antes de serem praticados sejam pensados; evitando assim que muitas famílias passem por situações constrangedoras.

Lembrando sempre que é livre a liberdade de expressão, porém sem abusos.

\begin{abstract}
ANÁLISE
$\mathrm{O}$ autor desconhece a estrutura dissertativa, pois desenvolve a redação sem organização, isentando o texto de articulação (MR4) e de continuidade (MR1) entre as partes integrantes: introdução, desenvolvimento e conclusão.

Notamos, em todo o texto, a falta de progressividade (MR2), revelada, mormente, pela desorganização textual. É nítida, pois, a falta de equilíbrio entre continuidade temática e progressão semântica. Nesse texto, não é possível reconhecer ordenação de causaconsequência entre argumentos expostos pelo produtor da redação.

A superficialidade das informações denuncia a falta de conhecimento do autor sobre o assunto e sua incapacidade em articular argumentos. Observemos os seguintes trechos: "Todos nós temos direitos a informação, desde que essa informação, seja transmitida de forma correta, e sem abusos.”; e "Garantiríamos essa liberdade de informação, através de informações limpas, isto é sem inventá-las.". O que o emissor fez foi apenas apresentar ideias genéricas que refletem o senso comum, sendo, portanto, passíveis de questionamento pelo leitor, o que compromete a aceitabilidade do texto.

Afirmações vagas de sentido, como as apresentadas, não contribuem em nada para a informatividade do texto.

Sobre a linguagem, é possível afirmar que o caráter pessoal pode ser identificado no fragmento: "Todos nós temos direitos a informação". A falta de adequação do texto à situação sociocomunicativa faz com que ele esteja em desequilíbrio ao conceito de situacionalidade.
\end{abstract}


Por fim, faltam pontos de vista mais elaborados e ideias adequadas ao real objetivo do texto. Além disso, é necessária a construção de um parágrafo conclusivo que contemple soluções para a problemática exposta, mostrando o posicionamento crítico do redator.

\section{2-7}

\section{A Imprensa}

A população sofre por não ter liberdade de informação, sem que sofram os abusos nos meios de comunicação. Pois deveria obter uma lei mais rígidas para a imprensa.

Devido a forma em que a imprensa age muitas das vezes o cidadão acaba se sentindo inútil, por não conseguir ao menos ter sua própria liberdade, pois tudo que acontecem de errado principalmente com o povo da periferia a imprensa vai em cima sem perder permissão, invade suas residências tirando fotos e anunciado para todo o mundo um assunto que só dizia respeito a família.

De acordo com o assunto mencionado os governantes têm que obter leis onde a imprensa antes de conseguir sua reportagem ou outros fatores como fatos e etc, teria que ter em mãos um papel com a assinatura do entrevistado.

\section{ANÁLISE}

A extrema dificuldade do autor em utilizar de maneira adequada a modalidade escrita da língua portuguesa é aparente. Além disso, o restrito conhecimento de mundo culmina na elaboração de ideias baseadas no senso comum.

Percebe-se em todo o texto que há falta de progressividade (MR2), sendo esta revelada, principalmente, pela desorganização textual, não havendo, dessa maneira, equilíbrio entre continuidade temática e progressão semântica.

A superficialidade das informações denuncia a falta de conhecimento do autor sobre o assunto, evidenciada, também, pela generalidade do título, e sua incapacidade de articular argumentos. Observemos o seguinte trecho: "De acordo com o assunto mencionado os governantes têm que obter leis onde a imprensa antes de conseguir sua reportagem ou outros fatores como fatos e etc, teria que ter em mãos um papel com a assinatura do entrevistado.". 
A última frase desse trecho apresenta lacunas textuais, pois não é informado ao leitor que papel seria esse, se seria um documento ou outra coisa. A falta de esclarecimentos prejudica a compreensão da mensagem.

O que o emissor fez foi apenas apresentar ideias genéricas, sendo, portanto, passíveis de questionamentos.

O emprego inadequado do recurso da MR1, quando há repetição automática do vocábulo "imprensa", acaba por empobrecer o texto.

Em síntese, faltam pontos de vista mais elaborados e ideias adequadas ao real objetivo do texto. Além disso, é necessária a construção de um parágrafo conclusivo que contemple soluções à problemática exposta, mostrando o posicionamento crítico do redator, além de enquadramento às metarregras propostas por Charolles.

\section{8-3}

\section{A mídia em sua casa}

A mídia hoje em dia usa de tudo para chamar a atenção.

Quando ligamos nossa televisão, ao longo do dia, podemos observar a transmissão de programas sensacionalistas afim de mexer com a emoção do telespectador. Programas policiais que exibem por exemplo a vida pessoal, de uma família com a renda miserável ou também a morte de bandidos em combate com policiais.

O drama na vida das pessoas não deve ser alvo de aumento no ibope, pois isso gera uma verdadeira humilhação às famílias necessitadas. A mídia pode e deve ajudar essas pessoas mas não precisa levar ao ar para que o Brasil inteira tome conhecimento. Devemos fazer as coisas sem interesse, sem esperar retorno.

\footnotetext{
ANÁLISE

De maneira global, podemos afirmar, de imediato, que o produtor desse texto não consegue expressar satisfatoriamente sua opinião, formando uma precária articulação e organização de suas ideias (MR4-articulação).

O autor aparenta desconhecer a estrutura dissertativa, pois produziu uma redação enxuta, o que deixa a argumentação comprometida, uma vez que não é possível desenvolvê-la com profundidade e consistência.
} 
A linguagem apresentada não é impessoal, o que pode ser observado através dos verbos "ligamos" e "devemos". Esse tipo de linguagem não está de acordo com o que permite a linguagem argumentativo-dissertativa

No primeiro parágrafo, encontramos o uso da expressão clicherizada “hoje em dia”, o que denuncia a falta de criatividade do autor ao iniciar sua redação.

De um modo geral, não há uma continuidade adequada (MR1), uma vez que há repetição lexical (mídia, programas, policiais), fazendo-se necessária a substituição dos termos através de sinônimos e pronomes.

No último parágrafo, que deveria expor uma conclusão, o autor não apresenta ideias consistentes, não se posiciona criticamente nem faz a tentativa de criar uma solução efetiva ao problema.

\section{3-4}

A informação, é um dos meios de comunicação mais eficaz de alguém saber alguma coisa. A informação nos traz conhecimento, aprendizagem como noticiários, piadas, esportes, etc. Hoje o palco, das informações é na internet, onde as pessoas ficam sabendo de qualquer coisa que queira saber sobre o mundo.

As vezes ela ultrapassa um pouco os limites, invadindo casas, as vezes tirando a "imagem" da pessoa, desestruturando a pessoa moralmente.

Eu acho, que a informação tem que ser "livre" desde que ela respeite, desde que ela se responsabilize por aquilo que estará dizendo.

Hoje em dia os meios de comunicação, assim como jornalistas, certas empresas, tem sido "exploradas". O abuso é muito grande, ninguém respeita ninguém, sim saem atropelando os outros, sem querer saber de nada. Eu acho que se uns respeitam os outros, não acontecem abusos no meio de comunicação.

\section{ANÁLISE}

Nota-se que o autor desconhece a estrutura dissertativa, pois desenvolve a redação sem organização, não possuindo articulação (MR4) nem continuidade (MR1) entre as partes integrantes: introdução, desenvolvimento e conclusão. 
Identificamos, em todo o texto, a falta de progressividade (MR2), revelada, principalmente, pela desorganização textual, não havendo, dessa maneira, equilíbrio entre continuidade temática e progressão semântica. Nesse texto, não é possível reconhecer ordenação de causa-consequência entre argumentos expostos pelo produtor da redação.

A superficialidade das informações denuncia o conhecimento limitado do autor sobre o assunto e sua falta de competência em articular argumentos. Observemos o seguinte trecho: "Hoje em dia os meios de comunicação, assim como jornalistas, certas empresas, tem sido “exploradas”. O abuso é muito grande, ninguém respeita ninguém, sim saem atropelando os outros, sem querer saber de nada”.

O que o emissor fez foi apenas apresentar ideias genéricas, sendo, portanto, passíveis de questionamentos pelo leitor, o que compromete a aceitabilidade do texto. Afirmações vagas de sentido, como as apresentadas, não contribuem em nada para a informatividade do texto.

Sobre a linguagem, identificamos um caráter pessoal nos seguintes fragmentos: "Eu acho, que a informação tem que ser "livre'”, "Eu acho que se uns respeitam os outros [...]".

A falta de adequação do texto à situação sociocomunicativa causa desequilíbrio com o conceito de situacionalidade.

Por fim, faltam pontos de vista mais elaborados e ideias adequadas ao real objetivo do texto. Além disso, é necessária a construção de um parágrafo conclusivo que contemple soluções à problemática exposta, mostrando o posicionamento crítico do redator.

\section{2-7}

No periodo atual, não existe aquela palavra igualdade social. Nas ruas principalmente. Quando uma pessoa de cor negra, uma pessoa mal arrumada, chega ao lado de uma pessoa com boa aparência.

Essa pessoa já fica com ma olha para essa pessoa com aparencia diferente. É então que entra o caso da vida social na mioria das repôrtagens e mecionado os casos da vida social de tráficos etc. E é dado sair casos das regiões de classe alta e é mais divulgado os fatos das favelas dos bairros mais humilde.

Quando aparece uma morte nesses bairros de classe alta eles já tem autoridade condições de evitar repórteres jornais e revistas, mas já nas favelas, é logo comunicado os jornais, radios, revistas, etc. 
Então mas já que tvs jornais, rádios e revistas são um meio de comunicação, tem que ter direito como todos aqueles que mencionão este fato. Tem que ter qualidade, humildade, no próprio coraçao tentando passar aquilo que você tem para quem não tem.

\begin{abstract}
ANÁLISE
$\mathrm{O}$ autor foge quase que totalmente ao tema. Além disso, possui dificuldade em utilizar a norma culta da língua portuguesa, apresentando sérias falhas no que compete à estruturação formal do texto. Os desvios são tantos que comprometem sua compreensão, pois, muitas vezes, o leitor percebe-se em meio a sequências ininteligíveis, como no segundo parágrafo:

Essa pessoa já fica com ma olha para essa pessoa com aparencia diferente. É então que entra o caso da vida social na mioria das repôrtagens e mecionado os casos da vida social de tráficos etc. E é dado sair casos das regiões de classe alta e é mais divulgado os fatos das favelas dos bairros mais humilde.
\end{abstract}

Há repetição lexical no decorrer do texto, com destaque para a palavra "pessoa", que é reiterada várias vezes. Pode-se afirmar que o mau uso da MR1 (continuidade-repetição) acentuou ainda mais a limitação lexical do emissor, prejudicando, também, a progressão do texto (MR2). Além disso, a carência de conectores (MR4) comprometeu a articulação entre frases e ideias, constituindo danos à argumentação do texto.

O último parágrafo mostra-se desconexo, não apresentando embasamento concreto. De mais a mais, o desfecho é, praticamente, incompreensível: "Então mas já que tvs jornais, rádios e revistas são um meio de comunicação, tem que ter direito como todos aqueles que mencionão este fato. Tem que ter qualidade, humildade, no próprio coraçao tentando passar aquilo que você tem para quem não tem.".

\title{
1132309-4
}

\section{Como garantir a liberdade de informação e evitar abusos nos meios de comunicação?}

Tanto nos rádios como nas tvs a liberdade de informação está passando dos limites limites esses estabelecidos por lei, os jornalistas estão literalmente invadindo a vida das pessoas com o propósito de torná-la pública por acontecimentos ocorridos com pessoas 
ligadas a sua vida, no entanto os jornalistas não medem as conseqüências dos seus atos que se tornam criminosos ao ponto da pessoa que tem a vida invadida não concorde com a atitude.

Os jornalistas tem total liberdade de se expressar para passar a informação, mas ele acaba tornando pública a vida de pessoas envolvidas. Isso ocorre muitas vezes no dia-a-dia de pessoas que tem parentes, amigos ou até mesmo vizinhos de alguma trajédia.

Os jornalistas que não respeitam a vida particular das pessoas podem sofrer consequências de processos chegando a acabar na prisão.

Para que isso não ocorra mais teriamos de ter mais participação ativa de órgãos que proíbam a reportagem de ser exibida em rede com relatos de vida privada da pessoa.

\section{ANÁLISE}

A redação inteira apresenta desestruturação, fator que compromete sua linearidade e coerência. Do mesmo modo, não há articulação (MR4) nem continuidade (MR1) entre as partes integrantes: introdução, desenvolvimento e conclusão.

O texto constrói com superficialidade os argumentos, os quais denunciam o conhecimento limitado do emissor sobre o assunto. O tema não é abordado corretamente, visto que o autor foge parcialmente à proposta temática.

Percebe-se, em todo o texto, que há falta de progressividade (MR2), revelada, principalmente, pela desorganização textual, não havendo, dessa maneira, equilíbrio entre continuidade temática e progressão semântica. Nesse texto, não é possível reconhecer ordenação de causa-consequência entre argumentos expostos pelo produtor da redação.

Há repetição lexical no decorrer do texto, com destaque para a palavra "jornalistas", que é reiterada várias vezes. Pode-se afirmar que o uso indevido do requisito de coerência da MR1 (continuidade-repetição) acentuou ainda mais a limitação lexical do emissor, prejudicando, também, a progressão do texto (MR2). Além disso, a carência de conectores (MR4-articulação) comprometeu a conexão entre as frases e ideias, constituindo danos à argumentação do texto.

Além da repetição lexical, encontramos repetições de ideias:

“[...] os jornalistas estão literalmente invadindo a vida das pessoas com o propósito de torná-la pública” - primeiro parágrafo.

“[...] ele acaba tornando pública a vida de pessoas envolvidas" - segundo parágrafo.

"[...] Os jornalistas que não respeitam a vida particular das pessoas"- terceiro parágrafo. 
O exagero na repetição de palavras e ideias fere o requisito de progressão (MR2), incorrendo no que Charolles chamou de "circularidade" do discurso.

O último parágrafo, que deveria ser destinado à conclusão do texto, não expõe solução para a problemática proposta, pois não há posicionamento crítico nem fundamentação. O que se vê é um parágrafo vago de sentido, que apenas expõe um comentário genérico. Esse fator leva ao total distanciamento do que se exige de um texto dissertativo, no qual são essenciais a argumentação e criticidade.

\section{7-5}

Temos direitos a nos manter informados, hoje em dia a maioria das pessoas tem acesso a jornal, televisão, revista etc, são meios que no dia-a-dia nos faz deparar com uma noticia nova.

A mídia informa fatos que da audiência, a guerra dos Eua contra o Iraque, a criminalidade no Brasil, a fome no Nordeste, nos arrecadamos as idéias que ela nos passa.

Os jogadores de futebol, atores são frequentementes alvos da midia. Os famosos alegam que há invasão de privacidades, calunias nas informações que sai na manchete a respeito deles e isto já está se transformando em normal acontecerem.

A imprensa já foi alvos de varios processos por arbitrarem dos meios de comunicação que a possui.

Há leis regulamentadas ao direito do cidadão a ter sua privacidade.

Em outros aspctos o cidadão é lesado por falta de informações, por não terem conhecimentos dos seus direitos. Como falta de exclarecimento de lojas ao cliente etc.

Por pais que não comentam os perigos e o plazer da vida.

As pessoas precisam se concientizar que temos a liberdade e o direito de ter conhecimento dos fatos é principalmente do que é necessário transmitir, pôs muitas vezes somos prejudicados por não possuir a informação.

\section{ANÁLISE}

A falta de conhecimento da estrutura dissertativa é evidente. Isso prejudica toda a articulação do texto (MR4), no que se relaciona, principalmente, à coerência. Sem a 
organização de seus argumentos, fica complicado para o emissor fazer a conexão entre causa, condição e consequência.

O texto não progride e os parágrafos são muito curtos e em grande número, oito no total, o que deixa a argumentação comprometida, uma vez que não é possível desenvolvê-la com profundidade e consistência.

Há trechos que são muitos genéricos de sentido e vazios de conteúdo semântico: "Há leis regulamentadas ao direito do cidadão a ter sua privacidade."

Por serem muito amplos, argumentos desse tipo não trazem nada de novo ao texto, por isso diminuem o grau de informatividade.

$\mathrm{Na}$ conclusão, o autor não expõe seu posicionamento crítico, nem sugere soluções plausíveis ao tema proposto. O que se vê é uma proposta sem fundamentação, vinda, basicamente, do senso comum.

\section{0-2}

\section{Até onde são capazes de chegar?}

Liberdade de informação, é a liberdade de se imformar ou de ser imformar ou de ser imformado, atraves dos meios de comunicações que publicam coisas que não deviam ser publicadas, como invadindo privacidas de algumas pessoas.

Todos querem ficar imformados de tudo que está acontecendo em nossa volta por essa veêm jornais, leêm revista e outros meios de se imformar, por isso que os meios de comunicações estão ligadas a liberdade de imformação.

Os meios de comunicações tem auxiliado bastante no mundo moderno que nós vivemos, levando imformação a quase todo mundo, mas ainda há muita gente carente dessa informação. Mas às vezes esses meios de comunicações que muitas das auxiliam, acabam prejudicando outras pessoas. A imprensa, critíca, elojia as vezes até invadem a privacidade das pessoas, dizendo coisas que não poderiam ser dita, mentem, vasculham repassado.

Enfim elas são capazes de auxiliar e prejudicar, para vender mais ou dar mais ibope, mas falam o que todas querem ouvir, ou saber.

\section{ANÁLISE}


O que mais chama atenção nesse texto é a repetição constante da palavra "informação" e do verbo "informar". Além de esse fator prejudicar a progressão do texto, demonstra, de maneira clara, a limitação vocabular do aluno. Fora a repetição lexical, encontramos, também, repetição de ideias.

O autor utiliza alguns conectores como "enfim”, "mas”, “às vezes”. Entretanto, ainda podemos perceber carência no requisito de articulação, visto que há comprometimento na conexão entre as frases e ideias, constituindo danos à argumentação do texto.

Há trechos que são muitos genéricos de sentido e vazios de conteúdo semântico: “ $O s$ meios de comunicações tem auxiliado bastante no mundo moderno que nós vivemos, levando imformação a quase todo mundo, mas ainda há muita gente carente dessa informação."

Argumentos desse tipo não trazem nada de novo ao texto, por serem muito amplos, diminuindo, assim, o grau de informatividade.

$\mathrm{Na}$ conclusão, o autor não expõe seu posicionamento crítico, nem sugere soluções plausíveis ao tema proposto. O que se vê são comentários praticamente ininteligíveis.

\section{6-1}

\section{Educando para mudar o final do filme}

Meios de comunicação, trata-se das diversas maneiras que o homem utiliza para trocar informações. Na aldeia global que é o século XXI os meios de comunicações são postos em evidência, à medida que a expansão de mercados e a ideia de mundo globalizado fez crescer a necessidade de utilização dos veículos informacionais. Não é diferente no Brasil onde a televisão torna-se o protagonista dessa trama trabalhando em um grande filme nacional chamado "Abuso do poder moderno".

No Brasil a liberdade de expressão artística e o fim da censura, resultados de muita luta contra um governo ditatorial e bárbaro, são direitos protegidos por lei. Presentes na constituição de 1988, esses direitos vem sendo utilizados como uma importante arma pela imprensa, que além de apresentar todo um lado positivo informacional de total necessidade para o país, aproveita desse benefício para também mostrar conteúdos maliciosos, para um povo ainda subdesenvolvido de educação precária com objetivo de alienar cada vez mais um povo já alienado.

Em décadas passadas, o Brasil passou por um modelo de governo muito cruel, a Ditadura. Nesses tempos o Estado tinha total controle sobre a imprensa e os meios de 
comunicação e o direito ao Hábeas Corpus fora suspendido, esse dentre outros fatores tornou o período alvo de inúmeros conflitos. Naquela época a população encontrava-se em sua maior parte engajada e totalmente a par da situação. Diferentemente de hoje em que a nossa nação passa por sérios problemas e a mídia ao invés de honrar a árdua vitória do fim da censura, acaba sendo a grande responsável pela alienação do povo, passando programas totalmente "industrializados" com pouca ou sem nenhum fim social.

Portanto, enquanto muitos criticam um dos atuais projetos de nosso excelentíssimo presidente Lula que pretende de uma forma geral censurar um pouco mais a mídia, deveríamos pensar que mesmo não sento tão positiva e progressista o projeto pode se tratar mesmo que de forma infeliz de uma primeira tentativa de amenizar o abuso de poder dos meios de comunicação. De forma alguma o direito a liberdade de informação deve se atingido, o principal problema aliás a base de todos os problemas de nosso povo está na educação. Só educando a população e dando condições dignas para sua criação a sociedade brasileira irá aprender a filtrar o necessário das informações recebidas, só educando a população poderemos por um fim bem interessante para o "abuso de poder moderno" em que o protagonista perca toda sua força para o seu "vilão" o povo.

\section{ANÁLISE}

O texto apresenta adequações no que se refere à MR1 (continuidade). Apesar de haver repetição lexical no decorrer da redação, a reiteração não prejudica a argumentação exposta.

O autor foge parcialmente ao tema proposto por não abordá-lo em sua plenitude, uma vez que discorre sobre a época da ditadura e sobre a qualidade dos programas televisivos atuais e não enfatiza o real objetivo do texto, que é propor soluções de como evitar os abusos da mídia e garantir a liberdade de informação.

$\mathrm{O}$ redator demonstra conhecimento da estrutura dissertativa, conseguindo construir suas etapas (introdução/ desenvolvimento/ conclusão) com desenvoltura e eficiência.

A produção textual inicia-se de maneira satisfatória e com progressividade. De um modo geral, o redator faz bom uso da MR4 (articulação), utilizando conectores que entrelaçam os argumentos. O texto apresenta boa progressividade (MR2), havendo equilíbrio entre continuidade temática e progressão semântica.

No segundo parágrafo, o autor faz referência à Constituição Federal. Assim, podemos perceber o recurso da intertextualidade, um dos sete fatores de textualidade propostos por Beaugrand \& Dressler. O redator discorre de maneira clara, conseguindo fazer relações 
coerentes que só aumentam a qualidade de seus argumentos e, por consequência, seu poder de persuasão.

Assim sendo, verifica-se que o texto tem um bom padrão de coerência estando de acordo com as metarregras propostas por Charolles.

\section{3-1}

\section{A prostituição dos meios de comunicação}

De acordo com a Constituição Federal, todas as pessoas têm direito à liberdade de expressão e à privacidade no que diz respeito à sua imagem e à sua vida íntima. Contudo, freqüentemente, presenciamos a violação da vida privada de pessoas públicas, ou não, nos meios de comunicação mais utilizados como a televisão.

As empresas de comunicação possuem responsabilidades sociais, e têm como principais objetivos atender às populações quanto à educação, informação e lazer. Ao contrário disso, essas empresas vêm, cada vez mais, abrindo espaço para programas que dão ênfase à vida íntima de alguma pessoa famosa, ou mesmo anônima, desrespeitando e invadindo sua privacidade. Isso acontece porque "é o que vende", ou seja, é o tipo de programa que dá mais audiência, logo é o que acaba gerando mais lucro para representantes e acionistas das empresas de comunicação.

Uma parte da população defende a idéia de que é necessário a implementação de órgãos que controlem ou fiscalizem a imprensa. Os defensores dessa teoria estão, em certa parte, certos, afinal não se pode permitir que empresas e jornalistas atuem desrespeitando pessoas sem serem responsabilizados por seus atos. Entretanto, tais atitudes poderiam ser encaradas como forma de repressão e censura, estando contra a liberdade de expressão e deixando de lado a democracia.

Algumas pessoas são incapazes de se sensibilizar ao ver imagens de cidadãos humildes passando por situações de agressão física ou moral. Outras, além disso, ainda concordam com esse tipo de ação. É esse o tipo de pessoa que nutre a imprensa sensacionalista. O desrespeito ao ser humano está tão presente nas nossas vidas, seja nas ruas, nas escolas, nos clubes ou na televisão, que estamos nos acostumando com ele e, o que é pior, aceitando-o.

É indiscutível o direito das pessoas à privacidade e à liberdade de expressão. Porém, o que não se pode admitir é que o direito de expressão de uma pessoa invada a privacidade de outra, expondo sua vida para toda a população. Para que esse tipo de reportagem, que já está 
se tornando comum, não tome conta dos meios de comunicação definitivamente, é imprescindível o pagamento de indenizações e, além disso, é importante que as pessoas se tornem mais sensíveis e vejam este tipo de acontecimento não mais como entretenimento, mas como motivo de reflexão. Só assim conseguiremos acabar com a prostituição dos meios de comunicação.

\begin{abstract}
ANÁLISE
Mais uma vez, o texto apresenta adequações no que se refere à MR1 (continuidade). Apesar de haver repetição lexical no decorrer da redação, a reiteração não prejudica a argumentação exposta.

A estrutura dissertativa é seguida e, de um modo geral, o redator faz bom uso da MR4 (articulação), utilizando conectores que entrelaçam os argumentos. O texto apresenta boa progressividade (MR2), demonstrando equilíbrio entre continuidade temática e progressão semântica.

Um fator de textualidade também pode ser notado quando o emissor faz referência à Constituição Federal, configurando a intertextualidade.

Embora o texto apresente um bom padrão de coerência, acabou infringindo, no primeiro parágrafo, a terceira metarregra de Charolles. Isso ocorreu devido ao fato de o autor utilizar a expressão “ou não”, após um argumento que acabou de apresentar.
\end{abstract}

\title{
1132362-0
}

\section{Liberdade de expressão}

"Liberdade de expressão", é notável a grande freqüência em que essa frase é ouvida no mundo atual. Obviamente, é correto que qualquer cidadão seja apto de se expressar, de expor suas idéias e pensamentos, porém muitas pessoas exageram na hora de desfrutar dessa liberdade.

Estamos vivenciando um período onde a mídia tem invadido cada vez com maior intensidade a vida das pessoas. Essa falta de ética ocorre com pessoas de boa condição econômica até com as pessoas de um nível econômico mais baixo do que o das outras. 
A livre expressão de uma atividade artística ou de comunicação, deve ser usada de maneira agradável, sem se tornar algo monótono, mas também é cabível que essa autonomia expressiva, não viole o íntimo do cidadão.

Não é preciso que seja divulgado o hábito de uma certa pessoa, não é necessário saber aonde aquele artista famoso vai jantar, nem mesma interessa saber algo que alguém cometeu de errado no passado, por isso serve apenas para prejudicar a pessoa em foco, e a nós, esse tipo de notícia, popularmente conhecida como fofoca, nada é acrescentada.

Todos têm o direito de falar suas opiniões, mas nunca devemos esquecer a maneira correta de usufruir desse presente, que é a liberdade de expressão, porque se houver um uso excessivo dessa liberdade, muitas pessoas serão prejudicadas, pois nada em excesso é bom.

\section{ANÁLISE}

Esta produção textual inicia-se de maneira satisfatória e com progressividade, estando coerente ao que postula a MR2. Percebemos, assim, equilíbrio entre continuidade temática e progressão semântica.

De um modo geral, o redator faz um bom uso da MR4 (articulação), utilizando conectores como "porém”, "mas”, "também”, “pois".

A coerência das informações aponta o conhecimento do autor sobre o assunto e sua capacidade em articular argumentos, fatores que só ampliam a aceitabilidade do texto pelo leitor.

Entretanto, há repetição de algumas palavras que poderiam ter sido substituídas ao longo da dissertação e o autor deixou de fazê-lo. Podemos destacar o vocábulo "pessoas", que é reiterado, principalmente, no terceiro parágrafo, situação que fere a MR1.

Em síntese, mesmo com os desvios à MR1, através da análise, percebe-se que o produtor dessa redação conseguiu manifestar sua opinião e construir argumentos consistentes, fazendo as conexões necessárias com eficiência. Tudo isso culminou em uma boa organização textual e no respeito à MR4 (articulação).

\section{7-6}

\section{Garantia de liberdade sem abusos}


Como garantir a liberdade de informação e evitar abusos nos meios de comunicação? Com a conscientização da mídia quanto ao limite da liberdade, a criação de um órgão público que fiscalize a imprensa, além da ajuda da população para moderar o nível de qualidade dos meios de comunicação.

A mídia, em geral, deve ter sempre em mente o seu limite e nunca ultrapassá-lo. E fazer o seu trabalho sem que haja sensacionalismo.

E também a criação de um órgão público que se destine à fiscalização da imprensa, e que seja imparcial e justo.

E ainda a população poderia ajudar nesse controle de qualidade, já que é ela que sustenta o meio de comunicação. Aquela recusando-se a assistir o lado negro desta conseguiria aumentar o nível do que é apresentado.

Enfim, garantir a liberdade de informação e evitar abusos nos meios de comunicação, depende das atitudes e ações de toda a sociedade. Através de nossa força de vontade e decisões é que conseguiremos solucionar os problemas que vivemos em nosso dia-a-dia.

\section{ANÁLISE}

De maneira geral, podemos dizer que há falta de progressividade (MR2) ao texto, o que revela, também, carência de organização textual. Não há, desta maneira, equilíbrio entre continuidade temática e progressão semântica. Nesse texto, não é possível reconhecer ordenação de causa-consequência entre os argumentos expostos pelo produtor da redação.

A progressão do texto é prejudicada pela falta de conectores (MR4-articulação), os quais estabeleceriam ligação entre os parágrafos e entrelaçariam os argumentos.

Notamos a repetição do conectivo "e”, o que recai numa infração à MR4 (articulação), uma vez que o autor poderia ter substituído o termo utilizando outros conectores.

Há repetição lexical dos termos "liberdade", "comunicação", "imprensa", "mídia”, o que denuncia o uso inadequado do requisito da MR1 (continuidade). No caso desse texto, o ideal seria utilizar os recursos de substituição através de sinônimos e pronomes.

Através da análise, podemos mensurar que o produtor dessa redação falhou ao manifestar sua opinião e ao construir os argumentos, os quais se deram de forma insatisfatória. Tudo isso culminou na falta de organização textual e de respeito à MR4 (articulação).

Falta em todo o texto consistência aos argumentos, os quais são apresentados de maneira superficial. A MR4 (articulação) é utilizada de forma precária. Em alguns momentos, 
o leitor se vê em uma sequência de frases desconexas, as quais seriam minimizadas se houvesse o uso de conectivos.

A conclusão é isenta de argumentação. Observa-se, apenas, generalidade no que o autor sugere para acabar com os abusos da mídia, não havendo criticidade. O autor não se posiciona na defesa de sua opinião, apenas reproduz uma ideia vaga de significação. Com base nisso, a informatividade desse texto fica bastante comprometida pela falta de ideias novas e por fazer o fechamento do texto de forma simplista e genérica demais.

\section{6-5}

\section{Para uma boa informação é preciso concientização}

Os meios de comunicação formam opinião a partir de seus interesses. O público acaba sedo vítima da manipulação, e por isso cada vez mais vem sendo questionado como evitar essa alienação. Talvez diminuindo a liberdade seria melhor. Mas conseqüentemente traria outros problemas. Então como resolver esta questão e ter boa informação sem censurá-la?

Não é uma tarefa fácil, mas tem solução. Uma delas seria através da educação. Se as escolas formam alunos pensantes que questionam sempre, ao invés de que aceita tudo, geraria um novo mercado de consumo de informação. Com isso os veículos teriam que suprir o interesse do público com informação de qualidade e não de acionistas e outros.

Mas para que isso aconteça tem que haver, indiscultivelmente, a intervenção do Estado. Ele tem que ser o primeiro a tomar a iniciativa. Através de campanhas, como uma propaganda que veinculou durante um tempo para incentivar a leitura. E utilização de verbas públicas para melhoria na qualidade de ensino.

Logo, a possibilidade de que a qualidade de imprensa melhore está totalmente ligado na melhoria da educação se a sociedade tiver seres pensantes com certeza a informação passará a ser muito melhor.

\section{ANÁLISE}

Essa produção textual inicia-se de maneira satisfatória e com progressividade e há coerência com o que postula a MR2, sendo possível perceber equilíbrio entre continuidade temática e progressão semântica. 
De um modo geral, o redator faz bom uso da MR4 (articulação), utilizando conectores como "mas", "logo", "então". Entretanto, ao utilizar o advérbio "talvez", denota dúvida e falta de certeza, o que não é condizente com o que se pede em um texto dissertativo. Além disso, verificamos repetições de algumas palavras que poderiam ter sido substituídas ao longo da dissertação e o autor deixou de fazê-lo. Destacamos o vocábulo "informação", que aparece várias vezes no decorrer do texto, situação que fere a MR1.

Em alguns momentos, há trechos obscuros, os quais necessitam de reescrita, como: “[...] a possibilidade de que a qualidade de imprensa melhore está totalmente ligado na melhoria da educação se a sociedade tiver seres pensantes com certeza a informação passará a ser muito melhor." Nesse momento, o leitor se pergunta se as informações melhorarão porque as pessoas são mais pensantes, ou se melhorará a forma como será abordada a informação em si, uma vez que a imprensa não tem como dar apenas notícias boas, ela expõe informações positivas e negativas.

Em síntese, mesmo com os desvios da MR1, através da análise podemos perceber que o produtor conseguiu manifestar sua opinião, mas faltou clareza em alguns momentos, sendo necessária reestruturação das sequências confusas.

\section{2-3}

A cada dia que passa, os nossos meios de comunicação se tornam mais fantásticos, hoje nós já podemos assistir a cores e a tempo real, o que está acontecendo do outro lado do mundo.

Mas o que era para ser usado a nosso favor, está sendo usado para denegrir imagem de famosos, invadir a sua privacidade. Sem contar que a mídia também é utilizada para influenciar a cabeça de seus telespectadores os levando a contrariar seus próprios princípios.

Difícil seria mudar tudo isso, afinal a informação é de grande importância para todos nós. As pessoas podiam se conscientizar mais, respeitando também uma lei já existente, sendo determinavelmente proibido a invasão de privacidade. Assim haveria a liberdade de informação para o bem, sem abusos dos meios de comunicação.

Será que teria sido melhor se nada disso tivesse acontecido? Se ao invés da informação, nós vivêssemos isolados, sem ao menos saber o que está acontecendo no país em que vivemos? Realmente é difícil de responder, já que todos nós estamos alienados nesse mundo com tecnologia de ponta. 
Morreríamos sem saber, afinal ninguém está disposto a trocar a informação pela privacidade e pela paz.

\begin{abstract}
ANÁLISE
O autor não demonstra conhecimento da estrutura dissertativa, pois não desenvolve o esquema "introdução-desenvolvimento-conclusão" com eficiência, prejudicando toda a articulação do texto (MR4).

Há trechos muitos genéricos e vazios de conteúdo semântico, como nos mostra o parágrafo introdutório: “A cada dia que passa, os nossos meios de comunicação se tornam mais fantásticos [...]”.

Comentários desse tipo não trazem nada de novo ao texto, por serem muito amplos. Não se sabe o que o autor quis dizer com a palavra "fantásticos". Não há explicação no texto para que o leitor possa fazer alguma relação. Tudo isso diminui o grau de informatividade dessa redação.

Alguns argumentos expostos pelo emissor geram polêmica, uma vez que são passíveis de contestação pelo receptor, sendo motivos de contestação, como no trecho: “[...] todos nós estamos alienados nesse mundo com tecnologia de ponta [...]”.

$\mathrm{Na}$ breve conclusão, o autor não expõe seu posicionamento crítico, nem sugere soluções plausíveis ao tema proposto. O que se vê é uma proposta sem fundamentação, proveniente do senso comum.
\end{abstract}

\title{
1132413-9
}

\section{Vamos botar Limites na imprensa}

Simplesmente fazer com que criem uma lei, que faça esses programas e rádios passam noticias interesantes.

Criar sim a liberdade de informação, pois assim todos teriam oportunidade de se defender.

Os jornalistas e a imprensa poderiam criar, algo com que os telespectadores possam se entereçar no assunto. É claro que em pedir lisença ficaria imposível, pois invasão a domicilio e crime. 
Deveria respeitar mais os cidadãos. A imprensa e muito sem limites pois se olvese algo que impedise de invadir a privacidade das pessoas.

Isso sim acabaria com o abuso nos meios de comunicação.

\begin{abstract}
ANÁLISE
Após a leitura do texto, percebemos a total falta de conhecimento do autor sobre a estrutura dissertativa. Este também não reconhece o tema como proposta para $o$ desenvolvimento de seu texto e sim, como uma simples pergunta, à qual faz a tentativa de responder.

Houve fuga parcial à proposta temática, fato que prejudica a argumentatividade, uma vez que o redator não contempla a proposta em sua totalidade, nos possibilitando afirmar que há discordância com a MR4 (articulação).

Em vários momentos, notamos que o autor inicia uma ideia e não a conclui antes de iniciar outra informação, o que, mais uma vez, mostra a falta de conectores (MR4-articulação) na constituição do texto.

A argumentação apresenta-se de maneira desorganizada, pois falta articulação entre as ideias expostas (MR4), revelada pela carência de recursos coesivos. A argumentatividade fica comprometida, visto que as sequências são desconexas e apresentam comentários que não contribuem para o desenvolvimento de um texto crítico e consciente.

Nota-se, também, que não há uma continuidade adequada (MR1), pois as palavras são repetidas e a dissertação fica empobrecida de recursos de retomada textual, tais como: sinônimos, pronomes ou advérbios. Tudo isso demonstra a limitação do léxico do autor, o qual também não possui um conhecimento aprofundado do tema, fato confirmado pela superficialidade dos argumentos apresentados.

No que diz respeito à informatividade, o autor não expõe nenhuma informação relevante, deixando a desejar nesse quesito. Apenas reproduz ideias genéricas, provenientes do senso comum, portanto, sem fundamentação.

A conclusão apresenta-se em um parágrafo muito curto, no qual não há argumentação. Observa-se apenas generalidade no que o autor sugere para acabar com aos abusos da mídia, não havendo criticidade.
\end{abstract}




\section{5-2}

\section{Os abusos cometidos pela mídia}

Os meios de comunicação são os principais influenciadores, na política, na vida social e na economia Mundial. No Brasil e em muitas nações, a imprensa já foi alvo de grandes opressões, principalmente militares, que tiraram a liberdade de muitos jornalistas, que foram obrigados a ficar escondidos e até mesmo irem para outros paises exercer sua profissão. Essa grande importancia da imprensa faz com que ela se sinta capaz de realizar o que quiser esquecendo de leis que não estão sendo executadas pela justiça.

Enquanto a dignidade de muitas pessoas são colocadas para a análise pública pela mídia, está só quer saber de se aproveitar mesmo causando injustiças e desrespeitos absurdos. Além de matérias sensacionalistas, matérias educacionais são publicadas e transmitidas para a população. Porém o sensacionalismo está tornando-se assustador, mostrando casos onde famílias sofrem perversas humilhações. Sem piedade, nem medo a mídia ataca, sabendo que dificilmente será punida pelos órgãos públicos que parecem fechar olhos para a realidade.

Como as empresas responsáveis pela imprensa são privadas escapam de muitas leis que provocariam uma menor mobilidade a elas. Mesmo pertencendo a grandes grupos empresariais a mídia, tem limites que não estão sendo respeitados, e mesmo assim nada está sendo feito porque seus donos são poderosos, e movimentam um amplo mercado por trás de tudo, por isso são "intocáveis".

Portanto deveria ter uma grande revisão das leis que falam da mídia, porém sem haver qualquer tipo de perda da liberdade da imprensa. A conscientização de jornalista e dos profissionais ligados à mídia também é um caminho para que acabe esses abusos. Pois esse segmento chamado imprensa é uma das profissões. Com mais formas de se chegar ao ápice, ao reconhecimento e com certeza isso pode ser alcançado de forma limpa e transparente sem machucar ou humilhar alguém.

\section{ANÁLISE}

O texto apresenta bom uso do requisito de coerência da MR1 (continuidade). Apesar de haver repetição lexical no decorrer da redação, a reiteração não prejudica a argumentação exposta.

O redator demonstra conhecimento da estrutura dissertativa, conseguindo construir suas etapas (introdução/ desenvolvimento/ conclusão) com certa desenvoltura. 
De um modo geral, o emissor utiliza adequadamente a MR4 (articulação), empregando conectores que entrelaçam os argumentos, tais como: "portanto", "porém", "além de".

O texto apresenta boa progressividade (MR2), o que denota equilíbrio entre continuidade temática e progressão semântica

Assim sendo, verifica-se que o texto tem um bom padrão de coerência, estando de acordo com as metarregras propostas por Charolles.

\section{0-9}

\section{Informação e Comunicação: nos ajudam ou prejudicam?}

É provável que são informações simples que são passadas através da mídia, são elas que mais mechem com a cabeça do telespectador. A mídia quer nos transmitir coisas do fruto dela não se importando com o que cada um vai receber da informação passada.

Informações do tipo que envolve tráfico de drogas, assassinatos e até mesmo nas novelas muitas vezes são transmitidas tais matérias que envolve quem vê.

A comunicação também é um grande fator para sertos problemas, porque nem sempre pessoas concordam com o que escutam, e por isso ao invés de resolver tudo em um diálogo já querem resolver em conflitos, discussões.

Continuando, a mídia gosta de aproveitar situações que o público participa, chama mais atenção. Pessoas gostam disso. Gostam

\section{ANÁLISE}

A redação inteira apresenta falta de organização, fator que compromete sua linearidade e coerência. O redator revela desconhecimento da estrutura dissertativa, comprovado pela pequena extensão do texto.

A superficialidade dos argumentos denuncia o conhecimento limitado do emissor sobre o assunto. O tema não foi abordado em sua totalidade, pois o autor limitou-se aos abusos da mídia e não discorreu sobre como garantir a liberdade de informação.

Não há continuidade adequada (MR1), uma vez que há repetição lexical automática ("informações", "mídia”, "pessoas”). Verificamos, também, trechos confusos que comprometem a progressão do texto (MR2). Esses fatores interferem na argumentatividade, 
que não convence o leitor pela falta de embasamento e profundidade dos comentários apresentados.

A argumentação apresenta-se de maneira desorganizada, pois falta articulação entre as ideias expostas (MR4), revelada pela carência de recursos coesivos. A argumentatividade fica comprometida, visto que as sequências são sem nexo e apresentam comentários que não contribuem para o desenvolvimento de um texto crítico e adequado.

Em alguns momentos, surgem períodos incompreensíveis, totalmente desconexos, como no quarto parágrafo: “[...] a mídia gosta de aproveitar situações que o público participa, chama mais atenção. Pessoas gostam disso. Gostam”.

$\mathrm{O}$ último parágrafo, que deveria ser destinado à conclusão do texto, não expõe nenhuma solução para a problemática proposta. Não há posicionamento crítico nem fundamentação das ideias. O que se vê é um comentário vago de sentido e incoerente ao contexto, o que leva ao total distanciamento do que se exige em um texto dissertativo.

\section{3-5}

A emprensa pode divulgar somente o necessário, sem violar a privacidade das pessoas, fazendo com que as notícias cheguem sem abusos da liberdade de expressão.

A emprensa em nosso país se tornou prejudicial, pois eles não respeitam mais ninguém eles só querem saber de vender e denegrir a imagem das pessoa, fazendo com que as pessoas tomem raíva e critiquem o seu trabalho.

Mais também tem seu lado positivo, porque se a emprensa não divulgar os fatos ocorridos o nosso país não vai para frente.

O direito de comunicação e nosso, mais precisamos rever o que é bom e o que é ruim, fazendo com que tenhamos uma ótima emprensa.

\footnotetext{
ANÁLISE

O que mais chama atenção nesse texto é a repetição constante da palavra "emprensa" (imprensa). Pode-se afirmar que o uso inadequado da MR1 (continuidade-repetição) acentuou ainda mais a limitação lexical do emissor, prejudicando, também, a progressão do texto (MR2).
} 
Além da repetição lexical, há reiteração de ideias. O exagero na reprodução de palavras e pensamentos fere o requisito de progressão (MR2), incorrendo no que Charolles chamou de "circularidade" do discurso.

O autor utiliza alguns conectivos como "pois" e "mais" (mas). Entretanto, ainda percebe-se a carência de uso dos conectores (MR4-articulação) devido ao comprometimento da conexão entre frases e ideias, constituindo danos à argumentação do texto.

Há trechos que são muitos genéricos, vazios de conteúdo semântico: "O direito de comunicação e nosso, mais precisamos rever o que é bom e o que é ruim, fazendo com que tenhamos uma ótima emprensa.". Comentários desse tipo não trazem informatividade ao texto.

No segundo parágrafo, notamos a utilização do recurso de retomada textual, através do uso do pronome "eles", sem que o autor explicite a quem está se referindo. Desta forma, é inevitável a pergunta: Eles quem?

A pronominalização seria aceitável desde que tivesse sido explicitado a quem "eles" está substituindo, pois o referente deveria ter sido apresentado ao leitor, para depois, de forma anafórica, ser utilizado o pronome em seu lugar. Verifica-se, desse modo, discordância com a MR1 (continuidade), no que diz respeito à substituição gramatical.

$\mathrm{Na}$ conclusão, o autor não expõe seu posicionamento crítico, nem sugere soluções plausíveis ao tema proposto. O que se vê são comentários sem fundamentação em um parágrafo extremamente pequeno, no qual é impossível realizar uma boa finalização de um texto essencialmente argumentativo.

\section{6-0}

\section{Liberdde de Expressão}

Os abusos nos meios de comunicação em nada tem haver com a liberdade de informação, mas sim com a livre expressão.

Os meios de comunicação abusam de sua liberdade de expressão para transmitir para o povo idéias que gostariam que fossem seguidas, como o consumismo.

Já o povo não pode perder a sua liberdade de informação, pois precisa saber o que ocorre no mundo e mesmo conhece-lo.

Os meios de comunicação deveriam ser punidos a cada informação falsa e expectativa que transmitem com as quais ganham cada vez mais dinheiro. 
A liberdade de expressão é ótima em quanto, não temtam ganhar dinheiro em cima dela e não utilizam-na para colocar em evidência a ignorância do povo que ouve utilizar da informação para ter cada vez mais conhecimento e não elevar sua ignorância.

\section{ANÁLISE}

Primeiramente, devemos dizer que o autor desconhece a estrutura dissertativa, pois desenvolve a redação sem organização, haja vista que a produção não possui articulação (MR4) nem continuidade (MR1) entre as partes integrantes: introdução, desenvolvimento e conclusão.

Notamos, em todo o texto, falta de progressividade (MR2), a qual é revelada, mormente, pela desorganização textual. Não há, pois, equilíbrio, tão mencionado por Charolles, entre continuidade temática e progressão semântica. Nesse texto não é possível reconhecer ordenação de causa-consequência entre argumentos expostos pelo produtor da redação.

Há repetição lexical dos termos: "informação", "liberdade”, "expressão", “comunicação", o que mostra, novamente, a inadequação do recurso da MR1 (continuidade).

A superficialidade das informações denuncia a falta de conhecimento do autor sobre o assunto e sua incapacidade em articular argumentos, apresentando apenas ideias genéricas que refletem o senso comum, sendo, portanto, passíveis de questionamentos pelo leitor, o que compromete a aceitabilidade do texto: "Já o povo não pode perder a sua liberdade de informação, pois precisa saber o que ocorre no mundo e mesmo conhece-lo."

Afirmações vagas de sentido, como a apresentada, não contribuem em nada para a informatividade do texto.

Em suma, faltam pontos de vista mais elaborados e ideias adequadas ao real objetivo do texto. Além disso, é necessária a construção de um parágrafo conclusivo que contemple soluções à problemática exposta, mostrando o posicionamento crítico do redator.

\section{4-5}

\section{Abuso alienado}

Nem tudo que assistimos na televisão é verdade, existe uma rede de manipulação que controla todos os dados de informações que visa passar o que eles querem. 
O povo brasileiro é muito subordinado o que passa na TV, não buscam outras alternativas de informações para obter uma visão crítica das coisas.

Sabendo disso, a imprensa abusa mostrando tudo o que eles querem, independente da informação apresentada sendo verdadeira ou não.

Podemos concluir que devemos estar atentos das informações apresentadas em qualquer meio de comunicação porque existe uma conspiração atras disso e reendificarmos uma lei contra esse abuso alienado.

\section{ANÁLISE}

Com base na leitura da redação acima, é possível afirmar que seu produtor apresenta dificuldades em desenvolver a estrutura de um texto dissertativo, visto que não produz suas etapas com eficiência (introdução, desenvolvimento e conclusão).

Ocorrências de repetição lexical são aparentes, com destaque para o vocábulo "informações". A reiteração automática de dada palavra empobrece o texto, pois o ideal seria utilizar os recursos de substituição através de sinônimos e pronomes.

Falta, em todo o texto, consistência aos argumentos que são apresentados de maneira superficial e frágil, o que diminui sua aceitabilidade pelo leitor.

A MR4 também é utilizada de forma precária, não sendo empregados recursos que confeririam ao texto um aspecto mais coeso, possibilitando o entrelaçar dos parágrafos e ideias expostas.

No primeiro parágrafo, notamos ineficácia na utilização do recurso de retomada textual através do pronome "eles", pois o autor não explicita a quem está se referindo. Assim, é inevitável a pergunta: Eles quem?

A pronominalização seria aceitável desde que tivesse sido explicitado quem "eles" está substituindo. O referente deveria ter sido apresentado ao leitor, para depois, de forma anafórica, ser utilizado o pronome em seu lugar. Verifica-se, desse modo, discordância com a MR1 (continuidade) no que diz respeito à substituição gramatical.

Por fim, faltam pontos de vista mais elaborados e ideias adequadas ao real objetivo do texto. Além disso, é necessária a construção de um parágrafo conclusivo que contemple soluções à problemática exposta, mostrando o posicionamento crítico do redator. 


\section{7-0}

\section{Constituição sem medo}

Quando se fala em controle de conteúdos na mídia fica evidente o temor brasileiro em relação ao assunto devido ao passado da censura no país. Entretanto é inadimissível ignorar os abusos contra os direitos individuais por parte de certos setores da imprensa.

A liberdade de expressão foi muito comemorada porém pouco discutida. O que gerou um ambiente sem regras no que diz respeito a essa área. $\mathrm{O}$ avanço das redes de informação, juntamente com a corrida do capital e o crescimento dos impérios empresariais atropelou o indivíduo. Relegado a segundo plano a transmissão do fato, que é seu fim.

Pertencente aos grandes conglomerados economicos a mídia por vezes esquece seu fim e passa a atender interesses particulares. Tal conduta põe em risco a credibilidade da notícia e por vezes o direito básico do indivíduo a condição moral e dignidade. Tal comportamento pode ser visto dos programas de TV apelativos à revistas sensacionalistas.

O trauma nacional em relação ao AI 5 deve ser superado para que tais abusos sejam impedidos. A solução encontra-se na própria Constituição: se a expressão é um direito e reprimi-la é um crime, mais criminoso é usar desse direito para ferir o outro. É papel do governo fazer com que isto se cumpra.

\section{ANÁLISE}

Esse texto apresenta adequação quanto ao requisito da MR1 (continuidade). Apesar de haver repetição lexical no decorrer da redação, a reiteração não prejudica a argumentação exposta.

O autor foge, parcialmente, ao tema proposto por não abordá-lo em sua plenitude, uma vez que discorre sobre a época da ditadura e sobre a qualidade dos programas televisivos atuais, e não enfatiza o real objetivo do texto, que é o de propor soluções de como evitar os abusos da mídia e garantir a liberdade de expressão.

O redator demonstra conhecimento da estrutura dissertativa, conseguindo construir suas etapas (introdução/ desenvolvimento/ conclusão) com desenvoltura e eficiência.

A produção textual configura-se de maneira satisfatória e com progressividade. De modo geral, o redator faz uso satisfatório da MR4 (articulação), utilizando conectores que entrelaçam os argumentos. O texto contém progressividade (MR2), demonstrando equilíbrio entre continuidade temática e progressão semântica. 
Nos quarto parágrafo, o autor faz referência à Constituição Federal, dando intertextualidade ao texto, um dos sete fatores de textualidade propostos por Beaugrand \& Dressler. O redator discorre de maneira clara, conseguindo fazer relações coerentes que só aumentam a qualidade de seus argumentos e, por consequência, seu poder de persuasão.

Entretanto, a solução proposta não traz novidade à problemática inserida pelo tema. $\mathrm{O}$ autor fica preso ao senso comum ao transferir, apenas ao governo, a responsabilidade de garantir a liberdade de informação e evitar os abusos dos meios de comunicação.

Assim sendo, verifica-se que o texto tem um bom padrão de coerência, estando de acordo com as metarregras propostas por Charolles, mas necessita de uma conclusão mais elaborada e serena.

\section{4-3}

\section{A influência que a mídia faz sobre a vida}

A TV tem como seu principal objetivo levar informações e interagir a população com os acontecimentos ocorridos no mundo, mas nem sempre é isso que acontece, acabam fazendo mais do que é realmente preciso.

O principal alvo de tudo que está acontecendo no país, é a população, pois por parte de políticos desonestos, reflete uma sociedade sem cultura, personalidade e opinião própria para selecionar frutos bons e ruins.

Com mais de $70 \%$ da população desinformada é fácil a mídia entrar na casa das pessoas e fazer uma "lavagem cerebral", pois tudo que "esses" podem fazer é se questionarem sem possuir uma resposta precisa para isso.

Grandes empresários que encontram-se por traz de empresas privadas, eles sim possuem um grande objetivo: manipular a cabeça dos cidadãos que não adiquirem capacidade de se expressar perante certas situações e ganhar muito dinheiro atravez desses atos.

Infelizmente, nem todas as pessoas do mundo terão possibilidade de saber e conhecer a "liberdade de informação", de se colocar a par de tudo e, ter uma opinião própria sabendo que seja qual decisão for , será por si só, com seus próprios princípios sem que ninguém precise fazê-lo chegar a uma conclusão, que mesmo que não seja a mais correta, partiu de seu próprio conhecimento cultural, social e mundial. 
Com base na leitura da redação acima, é possível afirmar que seu produtor apresenta dificuldades em desenvolver a estrutura de um texto dissertativo, visto que não produz suas etapas com eficiência (introdução, desenvolvimento e conclusão).

O terceiro parágrafo tem início com a afirmação “Com mais de $70 \%$ da população desinformada é fácil a mídia entrar na casa das pessoas [...]”. Entretanto, o autor não expõe com base em qual fonte fez essa afirmação; não fornecendo nenhuma fundamentação. Sendo assim, esse trecho configura um comentário genérico que reflete o senso comum, passível de questionamento pelo leitor, comprometendo, dessa forma, a aceitabilidade do texto.

De uma maneira geral, faltam à dissertação recursos coesivos de retomada (MR1continuidade) e conectores que estabeleçam ligação entre as frases e os parágrafos (MR4articulação).

O parágrafo destinado à conclusão do texto é totalmente confuso, sendo quase ininteligível. Há, pois, necessidade de reestruturação do parágrafo todo.

Notamos que na construção desse texto há fuga parcial ao tema, uma vez que o autor se preocupa apenas em discorrer sobre a má influência da mídia, não englobando, assim, o tema em sua totalidade.

\section{8-3}

\section{Liberdade Racional}

Sabe-se que a palavra liberdade está em destaque desde os tempos da Revolução Francesa. Todos a desejam, inclusive os meios de comunicação, que a utilizam como principal instrumento de trabalho. Difícil saber quando limitá-la, para não desrespeitar os princípios da moral e da ética.

O mundo globalizado tem estimulado a diversidade de equipamentos cada vez mais sofisticados nos meios de comunicação. Essa variedade intensifica a circulação de informações e de programas que atingem todas as nações e setores da população. Assim, o cuidado com a qualidade dos conteúdos a serem divulgados é essencial para que interfiram positivamente na formação do ser humano.

Os meios interativos são livres para transmitir a programação que desejam, porém tendo a consciência de sua responsabilidade social, devem desenvolver mecanismos para 
eliminar qualquer transgressão de valores. Desse modo, estarão contribuindo para a estruturação de uma sociedade mais humanitária.

Ademais, a quantidade de programas sensacionalistas e de reportagens que exibem cenas com alto teor de violência, aumentam progressivamente, uma vez que elevam a taxa de ibope das emissoras. Estes, podem causar alterações psicológicas e de caráter em muitas pessoas. Isso ocorre porque são influenciadas pela mídia, que impõe conceitos, padronifica pensamentos, o que faz com que muitos passem a agir de acordo com os seus preceitos.

Como se vê, o direito à liberdade é essencial nos meios de comunicação, portanto, como qualquer excesso é prejudicado, ela deve ser dosada. Tal medida será efetivada diante de uma conscientização de que temos que formar verdadeiros cidadãos e não homens medíocres, limitados de atitudes e ideais.

\footnotetext{
ANÁLISE

O autor foge, parcialmente, ao tema proposto por não abordá-lo em sua plenitude, não se focando no real objetivo do texto, que é propor soluções de como evitar os abusos da mídia e garantir a liberdade de informação.

$\mathrm{O}$ redator demonstra conhecimento da estrutura dissertativa, conseguindo construir suas etapas (introdução/ desenvolvimento/ conclusão) com desenvoltura e eficiência.

A produção textual inicia-se de maneira satisfatória e com progressividade. Globalmente, o redator faz bom uso da MR4 (articulação), utilizando conectores que entrelaçam os argumentos, e dessa forma dá ao texto um equilíbrio entre continuidade temática e progressão semântica.

A linguagem utilizada é impessoal, sendo adequada à modalidade escrita dissertativoargumentativa. Assim, a adequação do texto à situação sociocomunicativa faz com que ele esteja em equilíbrio ao conceito de situacionalidade.

No primeiro parágrafo, o autor faz referência à Revolução Francesa, configurando, claramente, a intertextualidade. O redator discorre de maneira clara, conseguindo fazer relações coerentes que só aumentam a qualidade de seus argumentos e, por consequência, seu poder de persuasão.

Assim sendo, verifica-se que o texto tem um bom padrão de coerência, estando de acordo com as metarregras propostas por Charolles.
} 
1132542-9

\section{Informação X Privacidade}

Sabe-se que a mídia quer chamar a atenção do mundo através da televisão, internet, jornais, revistas etc, para os problemas que este, por sua vez vem sofrendo ao longo dos anos, fazendo com que todos venham se conscientizar e buscar a fórmula certa para a solução de um mundo sem terrorismo, sem drogas, sem corrupção etc.

É importante notar que a mídia ao mesmo tempo que busca através de seus serviços, soluções para os problemas do mundo, enfoca por outro lado, a vida das pessoas, sejam ricas ou pobres. Notamos essas situações em revistas que mostram: o "vestido" que certa artista está usando para ir à um determinado lugar, ou na mostra da casa de outro que aparece na reportagem com a roupa que costuma dormir ou até mesmo sem quere aparecer, uma “celebridade", que é pega de surpresa pela imprensa saindo do cinema com o seu novo amor. Que falta de privacidade! Mas não são só os artistas têm o privilégio de serem vigiados pela mídia não. Vemos também em reportagens de cunho policial, pessoas que não aparecem na televisão com o papel principal de uma novela não, mas sim como protagonista de um grande assalto ou até mesmo assassinato, a ilutada família da vítima chorando pedindo justiça.

Conclui-se que a mídia desempenha um papel de registradora de todos os tipos de acontecimentos, sejam eles agradáveis ou não intensionais ou privativos, mas o que podemos mesmo fazer, para que esta venha ser utilizada de maneira que informações úteis sejam passadas para o mundo sem a invasão de privacidade, e com o estabelecimento de novas leis que venham realmente garantir a liberdade de todos, sejam famosos ou não, e o cumprimento de penas para aqueles que forem contra essas leis.

\section{ANÁLISE}

Com base na leitura da redação, é possível afirmar que o produtor apresenta dificuldades em desenvolver a estrutura de um texto dissertativo, visto que não produz suas etapas com eficiência. Além disso, os parágrafos são longos demais, o que deixa o texto cansativo para o leitor.

$\mathrm{O}$ autor foge, parcialmente, ao tema proposto por não abordá-lo em sua totalidade e por discorrer demais sobre os exageros cometidos pela mídia. Não há, pois, focalização no real objetivo do texto, que é o de propor soluções de como evitar os abusos da mídia e garantir a liberdade de expressão. 
Essa produção textual tem início satisfatório e contém certa progressividade, estando coerente ao que postula a MR2. Assim, fica fácil perceber equilíbrio entre continuidade temática e progressão semântica.

De um modo geral, o redator faz bom uso da MR4 (articulação), utilizando conectores como "mas", "por sua vez", "até mesmo".

Constata-se o caráter não-impessoal do texto no uso dos verbos "temos", "vemos" e "podemos"; e em comentários, como: “[...] 'celebridade', que é pega de surpresa pela imprensa saindo do cinema com o seu novo amor. Que falta de privacidade!'. O texto apresenta falta de adequação à situação sociocomunicativa, estando em desequilíbrio ao conceito de situacionalidade.

\section{4-7}

Niterói, 29 de agosto de 2004 "Como garantir a Liberdade de informação e evitar abusos nos meios de comunicações"

Creiamos que todos nos temos e devemos ter toda a liberdade do mundo, e para que isso possa acontecer, atravez de uma informação e um bom estudo, consegue chegar ao seu determinado obstaculo, pois com isso ele vai buscando o seu desenvolvimento e aprendendo que na vida tudo pode acontecer, nas melhores e piores situação de sua vida. Na verdade cabe a cada uma das pessoas escolher o seu próprio destino, o que querem e o que não querem fazer de suas vidas, pois se cada uma dessas pessoas conseguir chegar ao seu próprio destino como deve, muitas delas estavam evitando os abusos nos meios de tantas comunicações, pois é atravéz de má comunicação que muitas das pessoas são violentadas e estranguladas, sem saber onde foi parar o paradeiro dessas pessoas que na verdade estariam se achando espertas, mas no fundo de esperteza elas não tem nada, e nem procuram evitar para que nada disso o acontecesse, para que pudesse ter suas vidas em liberdades sem abusos.

\section{ANÁLISE}

O aspecto visual da redação já demonstra a total falta de conhecimento da estrutura dissertativa do autor, visto que não há paragrafação. O que se vê é um bloco contínuo de palavras. 
O produtor não reconhece o tema como proposta para o desenvolvimento de seu texto, pois o tratou como uma simples pergunta, à qual faz a tentativa de responder.

A falta de pontuação, além de outros fatores, prejudica o entendimento do que o emissor tenta dizer. A ausência de pausas na leitura, provenientes do uso da vírgula e ponto final, cria períodos muito longos, quase incompreensíveis. O texto inteiro apresenta falta de organização, possuindo carência de recursos coesivos e comprometimento em sua linearidade e coerência.

É preciso enfatizar que houve confusão por parte do emissor sobre o que é tema e o que é título, uma vez que repete-se a proposta no campo para o qual destina-se o título da redação.

Houve fuga parcial à proposta temática, fato que prejudica a argumentatividade, uma vez que o redator não contempla a proposta em sua totalidade. Assim, notamos uma discordância com a MR4 (articulação).

Em vários momentos, notamos que o autor não conclui a ideia que inicia e passa para outra informação, o que, mais uma vez, mostra a falta de conectores (MR4-articulação) na constituição do texto.

Nota-se, também, que não há uma continuidade adequada (MR1), pois as palavras são repetidas e a dissertação fica empobrecida de recursos de retomada textual, tais como: sinônimos, pronomes ou advérbios. Tudo isso mostra o léxico limitado do autor, o qual também não possui conhecimento aprofundado do tema, fato confirmado pela superficialidade dos argumentos apresentados.

O autor não expõe nenhuma informação relevante, deixando a desejar no quesito informatividade, pois reproduz apenas ideias genéricas, provenientes do senso comum e, portanto, sem fundamentação.

Essa redação é problemática no que diz respeito à coesão e à coerência, necessitando de reestruturação e reescrita. Assim, podemos afirmar que foram infringidas todas as metarregras postuladas por Charolles.

\section{5-0}

\section{O Poder do Público e a Auto-regulação}

Assegurar o poder de liberdade de expressão é fundamental a qualquer democracia. Porém delinear a tênue divisa entre o direito adquirido e o seu abuso pode se tornar um grande 
desafio para a sociedade. Então buscar alternativas apostando na auto-regulação dos meios de comunição e investindo em um público mais seletivo, pode nos ajudar a solucionar esse dilema.

A grande chave para o desenvolvimento de uma sociedade é a educação. Um povo educado é dotado de objetivos e expressão. Em última instância, poder de decisão. A escolha instintiva de todo ser humano é o que pensa ser melhor para si. A educação abre então o horizonte de possibilidades e escolhas do indivíduo, tornando a sociedade dona de sua própria evolução, reguladora de seu destino, optante política, econômica e socialmente.

Isolando nesse contexto o estudo da regulamentação da mídia, vemos que essa audiência que a sociedade representa é o grande triunfo de regulamentação natural dos meios de comunicação. Predominantemente controlados pela iniciativa privada, nossos meios de comunicação tem por premissa básica o lucro, atravéz da venda de espaços promocionais e publicitários na programação. Portanto programas de rádio e televisão, jornais e revistas tem sua existência continuada no livro. Então uma sociedade que existe, pode naturalmente selecionar as publicações e exibições mais adequadas, fadando às demais ao ostracismo.

Aliado a essa modificação social, um conselho de ética é fundamental. Para estabelecer diretrizes e organizar fórum permanente. Sobre os assuntos ligados à mídia. Essa instituição não-governamental formada pelos próprios profissionais das classes jornalística e publicitária pode ser eficiente controlador, sem esbarrar em censuras e mantendo-se sempre dinâmicos na sua função. Entre suas funções estaria de criar, implantar, atualizar e fazer cumprir um rigoroso código de ética; apurar e denunciar abusos; orientar nas diretrizes de formação de novos profissionais; investir obrigatoriamente na educão da sociedade atravez de projetos que utilizam de forma positiva o poder de comunicação em massa.

Unindo-se as forças destas duas polaridades, a que consome e a que produz mídia, educando uma e auto-regulando a outra, pode-se chegar a uma solução positiva para o dilema de evitar abusos e manter a liberdade, tornando os veículos de comunicação importantes ferramentas para o desenvolvimento social.

\section{ANÁLISE}

O redator demonstra conhecimento da estrutura dissertativa, conseguindo construir suas etapas (introdução/ desenvolvimento/ conclusão) com desenvoltura e eficiência. 
A produção textual apresenta-se de maneira satisfatória e com progressividade. $\mathrm{O}$ redator faz bom uso da MR4 (articulação), utilizando conectores que entrelaçam os argumentos, tais como: "portanto", “então", e "porém".

O texto também apresenta boa progressividade (MR2), havendo equilíbrio entre continuidade temática e progressão semântica.

A linguagem utilizada é impessoal, sendo adequada à modalidade escrita dissertativoargumentativa. Assim, a adequação do texto à situação sociocomunicativa faz com que ele esteja em equilíbrio ao conceito de situacionalidade. $\mathrm{O}$ redator discorre de maneira clara, conseguindo fazer relações coerentes que só aumentam a qualidade de seus argumentos e, por consequência, seu poder de persuasão.

Assim sendo, verifica-se que o texto tem um bom padrão de coerência, estando de acordo com as metarregras propostas por Charolles.

\section{7-6}

\section{A mídia: orienta ou questiona o ser humano?}

A comunicação brasileira está em vias de ascensão, baseando-se em fatos, acontecimentos trágicos de emotivos e até mesmo a vida pessoal que podem ser discutidos e analisados através das aparições reveladas pela mídia que ao menor sinal de novidade, seja qual for sua originalidade, aparece para que a mesma possa ser relatada.

Trata-se de uma medida de mundialização das informações que torna mais visível o processo de globalização mundial no entanto é favorável que haja essa liberdade de transmissão de informações desde que não interfira nas relações pessoais e privacidade alheia.

Contudo, é necessário que determinadas informações de cunho histórico, político, cultural, socioeconômico se prolifere pelo mundo, porém não englobadas a assuntos promíscuos e absolutamente desnecessários a uma sociedade culta e atualizada.

\section{ANÁLISE}

A redação inteira apresenta falta de organização, fator que compromete sua linearidade e coerência. $\mathrm{O}$ redator revela desconhecimento da estrutura dissertativa, comprovado pela pequena extensão do texto. 
A superficialidade dos argumentos denuncia o conhecimento limitado do emissor sobre o assunto. $\mathrm{O}$ tema não foi abordado em sua totalidade, pois o autor não discorreu sobre como garantir a liberdade de informação.

Não há continuidade adequada (MR1), uma vez que há repetição lexical automática, com destaque para o termo "informações", que é reiterado algumas vezes.

Há, também, trechos confusos que comprometem a progressão do texto (MR2), como o primeiro parágrafo, que é totalmente desconexo. Esses fatores interferem na argumentatividade, que não convence o leitor pela falta de embasamento e profundidade dos comentários apresentados.

A repetição de ideias também é bastante presente:

"Trata-se de uma medida de mundialização das informações que torna mais visível o processo de globalização mundial [...]”.

“Contudo, é necessário que determinadas informações de cunho histórico, político, cultural, socioeconômico se prolifere pelo mundo, porém não englobadas a assuntos promíscuos $[\ldots] ”$...

O exagero na repetição de ideias fere o requisito de progressão (MR2), incorrendo no que Charolles chamou de "circularidade" do discurso.

A argumentação apresenta-se desorganizada, pois falta articulação entre as ideias expostas (MR4), revelada pela carência de recursos coesivos. A argumentatividade fica comprometida, visto que as sequências não têm nexo e apresentam comentários que não contribuem para o desenvolvimento de um texto crítico.

O último parágrafo, o qual deveria fazer o fechamento das ideias expostas no texto, não apresenta nenhuma conclusão; inicia-se com a conjunção adversativa "contudo", e logo em seguida o autor faz uso de outra conjunção adversativa "porém", situação que deixa o texto confuso e contraditório, ferindo, dessa maneira, a MR3 (não-contradição).

\section{8-5}

O Brasil foi um país que num período de sua história sofreu a ditadura militar, em que direitos como a liberdade foram retirados. Com a queda do Muro de Berlim, e vitória definitiva do capitalismo, a imprensa é livre para informar. Mas a televisão e outros meios de comunicação hoje, vem abusando e invadindo a moralidade de pessoas. A falta da ética 
profissional, as leis que não são de conhecimento de todos e não cumprida e também a falta de fiscalização, colaboram com o descontrole da mídia.

Emissoras de televisão em busca da maior audiência, fazem jornalistas pecarem com a ética profissional, ignorando os direitos de um cidadão e desrespeitando a Constituição Brasileira.

No artigo quinto a Constituição de 1988, é livre a expressão intelectual, artística, mas é inviolável a invasão da imagem e da honra. Pela ignorância de muitos, pela falta de conhecimento dos direitos, os brasileiros nada fazem quando são desrespeitados pela mídia. É preciso de um orgão fiscalizador para alertar e exigir indenização ao indivíduo lesado, e já impedir a exibição de programas que desrespeitam a moral de um cidadão.

A liberdade de comunicação na verdade, é garantida, o que é preciso é evitar os abusos desta liberdade. Criando uma organização fiscalizadora de caráter democrático, empregando jornalistas críticos e éticos, conscientizar o cidadão de seus direitos, e por último explicar a todos o que significa a palavra liberdade.

\section{ANÁLISE}

Com base na leitura do texto em questão, é possível afirmar que o produtor apresenta dificuldades em desenvolver a estrutura de um texto dissertativo, visto que não produz suas etapas com eficiência (introdução, desenvolvimento e conclusão).

O parágrafo introdutório é extenso demais, se comparado aos outros que constituem o texto. Faltam conectores (MR4) que possam realizar a articulação entre os argumentos expostos. Em um primeiro momento, o autor discorre sobre a ditadura militar no Brasil e, sem explicar, passa a escrever sobre o Muro de Berlim, não estabelecendo qualquer relação entre um elemento e outro.

Os argumentos apresentados são duvidosos, o que compromete a aceitabilidade do texto, visto que o leitor pode questionar e refutar as ideias contidas na argumentação.

No terceiro parágrafo, o autor se apropria de trechos da Constituição Federal para dar mais credibilidade à argumentação desenvolvida. Percebe-se, nesse momento, que há intertextualidade, um dos sete fatores de textualidade propostos por Beaugrand \& Dressler.

Somente na conclusão o redator apresenta uma proposta para solução da problemática e, ainda assim, não tece comentários persuasivos. 


\section{6-6}

\section{Como garantir a liberdade de informação e evitar abusos nos meios de comunicação}

Hoje, no mundo da comunicação, as coisas estão fugindo do controle. Os programas de comunicação estão confundindo curiosidade com a comunicação.

Os programas de TV, a cada instante entra na vida das de baixa renda, mostrando suas misérias e dificuldade, à busca da tão desejada audiência.

Atualmente isso vem acontecendo no meios de programas de informação, no qual aproveitam para mostrar o sofrimento das pessoas através da fome e do preconceito, e sem ter idéia do que é viver esses problemas na pele.

O número de patrocinadores de programas de fofoca está crescendo muito ultimamente, fazendo com que os telespectadores não tenha a opição de ver um programa educativo e recreativo.

O pior é que a humanidade está se deixando levar por esse lado de mentiras e intimidações.

A falta de liberdade que a imprensa tem para com o cidadão é um tema muito discutido ultimamente, porque acaba afetando a responsabilidade de muitos jornalistas.

O que devemos fazer é correr atrás de nossos direitos e garantir a liberdade de informação que é direito de todos.

\section{ANÁLISE}

De uma maneira global, percebemos, de imediato, que o produtor desse texto não consegue expressar satisfatoriamente sua opinião, formando uma precária articulação e organização de suas ideias (MR4).

$\mathrm{O}$ autor aparenta desconhecer a estrutura dissertativa. Ao discorrer em sete parágrafos muito curtos, deixa a argumentação comprometida, uma vez que não é possível desenvolvê-la com profundidade e consistência.

Há trechos que são muito vazios de sentido, passíveis de questionamento pelo leitor, como: "Hoje, no mundo da comunicação, as coisas estão fugindo do controle. Os programas de comunicação estão confundindo curiosidade com a comunicação."

Argumentos desse tipo não trazem nada de novo, sendo, dessa maneira, apenas reprodutores do senso comum. 
Ocorrências de repetição lexical são aparentes, com destaque para os vocábulos "programas" e "comunicação". A reiteração automática das palavras empobrece o texto, pois o ideal seria utilizar os recursos de substituição através de sinônimos e pronomes.

O exagero na repetição de palavras e ideias fere o requisito de progressão (MR2), incorrendo no que Charolles chamou de "circularidade" do discurso, o que pode ser notado no trecho: "Hoje, no mundo da comunicação, as coisas estão fugindo do controle. Os programas de comunicação estão confundindo curiosidade com a comunicação.”.

De modo geral, existe falta de progressividade (MR2), revelada, principalmente, pela carência de organização textual, não havendo, dessa maneira, equilíbrio entre continuidade temática e progressão semântica. Nesse texto, não é possível reconhecer ordenação de causaconsequência entre os argumentos expostos pelo produtor da redação.

\section{$1132635-2$}

A imprensa é um poder de estudos sociais intensificadamente visto em qualquer local do mundo.

As possibiliddes da hegemonia jornalística trabalhadas em cima do povo, são e sempre foram realmente inéditas.

Está para renascer o dia que imprensa controlava a censura. Portanto a garantia da liberdade de informações e abusos nos meios de comunições seria a mesma que evitar a ciência humana, ignorar suas virtudes e afinidades para com ela, e os secundários em sua volta.

Em relação a essas situações de censuras mal implícitas se negar a realidade que é exposta atualmente, a sociedade estaria vivendo uma vida de metafísica. Entretanto não haveria como concretizar esse tema que aborda principalmente a classe inferior pois o assunto desse texto é similar a imprensa.

Ao meu ponto de vista o que mostra a realidade, o que mostra defesa, fome, crimes. Genocídios como estes é a pedra no caminho social. Mas a imprensa que é a verdadeira política e polícia em proteção humana.

\section{ANÁLISE}


$\mathrm{O}$ autor desconhece a estrutura dissertativa, pois desenvolve a redação sem se ater à estrutura. Desta forma, o texto não possui delimitação, articulação (MR4), nem continuidade (MR1) entre as partes integrantes: introdução, desenvolvimento e conclusão.

A linguagem utilizada, em alguns momentos, possui caráter pessoal, como no trecho: "Ao meu ponto de vista o que mostra a realidade [...]". Assim, a falta de adequação do texto à situação sociocomunicativa faz com que ele esteja em desequilíbrio ao conceito de situacionalidade.

A oralidade também está presente, quando o autor afirma que "Está para renascer o dia que a imprensa controlava a censura”, utilizando expressão típica da fala e não da escrita, conferindo ao texto um caráter informal, o que não deveria acontecer.

Não existe progressividade (MR2) no texto. Dessa maneira, o equilíbrio entre continuidade temática e progressão semântica não é atingido. Nesse texto, não é possível reconhecer ordenação de causa-consequência entre os argumentos expostos pelo produtor da redação.

Falta em todo o texto consistência aos argumentos. A MR4 (articulação) é utilizada de forma precária. Em alguns momentos, o leitor se vê em uma sequência de frases desconexas, as quais seriam minimizadas se houvesse o uso de conectivos.

\section{1-4}

\section{Saber informar, sem abusar}

É comum ver os meios de comunicação abusando da privacidade de muitas pessoas. Eles correm atrás de notícia. Tudo bem, é um direito deles! Fazem isso, pois é o trabalho deles, ganham a vida desse jeito. Mas será que é justo, jornais e revistas publicarem notícias de cunho íntimo sobre artistas ou qualquer cidadão brasileiro sem ao menos pedir permissão?

São vacilos como esse que fazem com que a mídia seja muito contestada não só no Brasil, mas também no mundo inteiro. Decretar a censura seria voltar a um passado não muito distante mais especificamente a Ditadura Militar. Porém, como vivemos num país democrático melhor nem pensar nisso.

Uma solução viável para tais transtornos entre comunicação e população seria criar leis que punissem severamente àqueles veículos de comunicação que por ventura violasse a intimidade, a vida privada, a honra ou a imagem da pessoa exposta na publicação. Essas 
atingiriam diretamente o bolso dos "infratores" e por isso ficariam mais precavidos ao publicarem suas notícias.

Ou então, uma medida bem menos drástica que a citada anteriormente que teria o intuito de beneficiar ambas as partes. Para evitar processos judiciais por tal foto ou artigo publicado os meios de comunicação, antes de mais nada pediriam permissão a pessoa que pretendem colocar em sua revista ou jornal, para então fazer a publicação.

Enfim, seja através de leis ou mesmo de uma simples conversa, um entendimento entre ambos é possível respeitar a liberdade de informação (os que publicam) e evitar o constrangimento e até a raiva dos "publicados".

\section{ANÁLISE}

Verificamos nessa redação uma tentativa do autor em estruturar o texto de acordo com o gênero requerido, apesar das falhas e do fraco conteúdo.

A linguagem informal não é adequada, pois não é aceita pela modalidade escrita dissertativo-argumentativa: "Eles correm atrás de notícia. Tudo bem, é um direito deles!". Assim, a falta de adequação do texto à situação sociocomunicativa faz com que ele esteja em desequilíbrio ao conceito de situacionalidade.

A oralidade é bastante presente através de gírias, como no trecho: "São vacilos como esse [...]”. Tal vocabulário é típico da fala e não da escrita, conferindo ao texto um caráter informal, o que não deveria acontecer.

De modo geral, o produtor faz bom uso da MR4 (articulação), possibilitando a conexão entre os parágrafos e argumentos. Percebe-se que no decorrer da redação são utilizados conectores, como: "enfim”, "então", "porém” e "mas".

Em alguns momentos, o emissor poderia ter efetuado a retomada de alguns termos de outra forma que não fosse a de repetição. Através do uso de pronominalização e sinônimos, por exemplo, seria possível evitar a reiteração desnecessária, como no caso do vocabulário "comunicação".

Em síntese, o texto analisado não possui grandes desvios às metarregras propostas por Charolles, mas necessita de adequação na linguagem, visando conferir mais formalidade e credibilidade aos argumentos apresentados. 


\section{$1132665-4$}

\section{Televisão sem controle}

Um dos grandes problemas da sociedade brasileira nesses últimos anos vem sendo a falta de fiscalização no meios de comunicação do nosso país. Chegou o momento de refletir e pensar numa maneira de garantir a liberdade de informação evitando os abusos nos meios de comunicação.

Uma comprovação dessa falha na fiscalização são os programas de TV que são desestruturados e não possuem nenhum fundo ético, nem moral, ou seja, são programas que só tem um único objetivo que é prender a atenção do telespectador para ganhar audiencia. Tudo o que precisamos é de fiscalização para que seja proibido a utilização desses programas na televisão brasileira.

O grande problema, principalmente da telecomunicação brasileira, são os representantes e acionistas dessas empresas privadas que se acham no direito de manipular as notícias para obter lucros. A vitrine dessa ação dos poderosos da televisão é a sociedade brasileira que possui uma elite rica, uma classe média desempregada e uma terceira classe vivendo na miséria.

Para acabar com esses abusos na comunicação e continuar garantindo a liberdade de informação na sociedade do nosso país é preciso que haja fiscalização nos meios de comunicação. E essa fiscalização não pode ser feita por uma entidade civil, ela tem que ser feita por um órgão governamental, ou seja, cabe aos políticos do nosso país resolver esse problema e limpar a televisão brasileira.

\section{ANÁLISE}

O autor demonstra conhecer a estrutura de um texto dissertativo, pois desenvolve a redação com certa organização, apresentando linearidade nas partes integrantes: introdução, desenvolvimento e conclusão.

Em alguns momentos, o autor poderia ter efetuado a retomada de alguns termos de outra forma que não fosse a repetição (MR1). Através do uso de pronominalização e sinônimos, por exemplo, seria possível evitar a reiteração desnecessária, como no caso do vocábulo "fiscalização".

Além da reiteração de palavras, encontramos repetições de ideias, o que mostra o vocabulário restrito do emissor e a falta de conhecimento a respeito do tema. Essa repetição 
fere o requisito de progressão (MR2), incorrendo no que Charolles chamou de "circularidade" do discurso:

"Um dos grandes problemas da sociedade brasileira nesses últimos anos vem sendo a falta de fiscalização [...]”.

"Uma comprovação dessa falha na fiscalização [...]”

“Tudo o que precisamos é de fiscalização [...]”.

“[...] é preciso que haja fiscalização nos meios de comunicação.”.

Em síntese, o texto analisado possui desvios às metarregras propostas por Charolles, necessitando de adequação às MR1 e MR2.

\section{1-6}

\section{Os jornalista}

Alguns jornalista não tem nenhum respeito eles só querem arancar materias, e muitas das vezes eles em venta fatos que não tem nada a ver com oque aconteceu muitos jornalista são mortos e ninguém sabe porque.

Em vista que foi falado os jornalista devem tomar muito cuidado, porque no mundo de hoje esta muito perigoso. Alguns jornalista arisca muito sua vida para fazer uma materia, muitas das vezes elas não são nem uteis.

Muitos jornalis morreram em morros e favelas pirigosas no Rio de Janeiro; isso deve servir de exemplo para todos que trabalham nossa area todos nós sintimos por muito que já foram para o céu por causa de fato importante no morro e favelas.

\section{ANÁLISE}

O produtor desse texto possui dificuldade em utilizar a norma culta, apresentando sérias falhas no que compete à estruturação formal do texto, tais como: ortografia, concordância verbal/nominal, acentuação, pontuação. Os desvios são tantos que comprometem a compreensão do texto.

Com base na leitura realizada, é possível afirmar que o escritor da redação desconhece a estrutura e características dissertativas. É presente a fuga parcial do tema, uma vez que a proposta temática não é contemplada em sua totalidade. O redator não apresenta as ideias de 
maneira clara e peca pela falta de uso de recursos coesivos. O texto é muito carente de estruturação, necessitando de adequações à MR4 (articulação).

Os argumentos apresentados são desconexos e redundantes. Isso demonstra a falta de conhecimento do autor sobre a temática. Assim, o emissor não contribui com acréscimos semânticos, não soma novas ideias e não faz inferências ao que já foi informado.

Essa análise mostra que o texto distancia-se do que consta na MR2 (progressão) e do conceito de informatividade postulado por Beaugrand \& Dressler.

Outro fato que chama atenção é a constante reiteração do termo "jornalista". O exagero na repetição de palavras e ideias fere o requisito de progressão (MR2), incorrendo ao que Charolles chamou de "circularidade" no discurso. Notamos, também, que as afirmações são absolutamente desprovidas de informatividade.

Na realidade, em todo o texto a MR1 (continuidade) é mal desenvolvida, visto que há excessiva repetição lexical que ocorre com os vocábulos "morros", "favelas" e "matérias", revelando o vocabulário limitado do autor, que não consegue utilizar outros recursos de substituição, como os sinônimos, por exemplo.

No último parágrafo, o qual deveria expor uma conclusão, o autor não apresenta ideias próprias, não há posicionamento crítico por parte do redator, nem tentativa de criar uma solução para o problema, uma vez que não indica sugestões concretas para resolver a situação. Assim, não foi realizada a conclusão, pois o que se tem, no último parágrafo, é um comentário que não demonstra posicionamento crítico do autor e que termina em linhas desprovidas de fundamentação e lógica.

Em suma, há necessidade de reestruturação do texto e de adequação às metarregras postuladas por Charolles.

\section{0-6}

\section{Na capa do jornal... o próprio jornal}

Como já se sabe, as manchetes de jornais ou de revistas que producem maior lucro, são quase que necessariamente, aquelas que chocam as pessoas de maneira negativa, geralmente denegrindo a imagem de uma outra pessoa.

O que talvez não saibamos, é do que a imprensa é capaz para poder estampar tais manchetes na capa de seus jornais. 
É claro que não podemos generalizar pois felizmente, mesmo que ainda em extinção, há aqueles que não deixam faltar caráter e dignidade em seu trabalho.

Talvez o que muitos tenham vontade de sugerir, esteja fora de cogitação, mas vale a pena ao menos ser dito.

Quem sabe, se a manchete que estampasse a capa de um jornal hoje, nada mais fosse do que a estampa da própria incompetência de quem lhe escreveu? Toda sua falta de caráter, moral e dignidade.

É... venderia como água.

Mas acredita-se que não seria concebível.

Será que é porque olhamos de maneira diferente quando é a nossa integridade que está em jogo?

\begin{abstract}
ANÁLISE
Após a leitura do texto em questão, constata-se que a linguagem é repleta de pessoalidade, conforme os trechos: "O que talvez não saibamos [...]”; "É claro que não podemos generalizar [...]"; "Será que é porque olhamos de maneira diferente [...]".

Há, também, traços de oralidade e expressões de cunho popular, os quais deixam o texto com aspecto informal: "Quem sabe, se a manchete que estampasse a capa de um jornal hoje, nada mais fosse do que a estampa da própria incompetência de quem lhe escreveu? [...] É... venderia como água.”.

Parágrafos muito curtos, oito no total, e em grande número deixam a argumentação comprometida, uma vez que a quantidade de linhas não possibilita o desenvolvimento de argumentos com profundidade e plausibilidade.

Os argumentos apresentados são desconexos e totalmente questionáveis, o que compromete a aceitabilidade do texto, visto que o leitor pode protestar e refutar as ideias contidas na argumentação.

Argumentos desse tipo não contribuem para a criticidade nem para a persuasão do texto. Não trazem nada de novo ao leitor, não conferindo, dessa forma, informatividade à dissertação.

Com base na leitura realizada, é possível afirmar que o produtor dessa redação desconhece a estrutura e características dissertativas. É presente a fuga parcial ao tema, pois a proposta temática foi contemplada superficialmente. O redator não apresenta as ideias de
\end{abstract}


maneira clara e peca pela falta de uso de recursos coesivos. O texto é muito carente de estrutura, necessitando de adequações à MR4 (articulação).

O último parágrafo, que deveria ser destinado à conclusão do texto, não expõe nenhuma solução para a problemática proposta, pois não há posicionamento crítico nem fundamentação. O que se vê é uma pergunta retórica, vaga de sentido e incoerente ao contexto, o que leva ao total distanciamento do que se exige de um texto dissertativo, no qual são primordiais a argumentação e a criticidade.

\section{9-7}

Hoje em dia, ao passar do tempo, não temos mais liberdade sobre as informações, e as que chegam, assustam e por abusos nos meios de comunicações estamos vivendo num mundo violento onde rádios e tvs, só mostram mortes, de pessoas inocentes, mostram também as autoridades: policiais, comandantes etc. pessoas em que nós podíamos confiar e que são eles que saem todos os dias nas capas de jornais como assassinos, ladrões, policiais que ficam extorquindo dinheiro dos cidadões humildes, pois com certeza se eles fossem extorquir um cidadão de classe alta ele estaria perdido ou expulso a muito tempo, mais como eles não são bobos, só cometem violência com pessoas de classe baixa, que moram em ruas e favelas.

O mundo está perdido pois apesar de bandidos corruptos temos também policiais e autoridades corrupitas.

Os meios de comunicações sofrem também muitos abusos tanto pela sociedade, ou melhor pelo mundo todo.

Só conseguiremos realmente liberdade as informações quando realmente o mundo melhorar com essa violência, pois só assim iremos evitar o abuso nos meios de comunicações, onde também sofrem muito os jornalistas, a imprensa por falta de liberdade de informações, abusos no meio das comunicações, abusos nos meios das comunicações, e também por falta de segurança.

\section{ANÁLISE}

Primeiramente, devemos dizer que o autor desconhece a estrutura dissertativa, pois desenvolve a redação sem estruturá-la. Assim, a produção não apresenta articulação (MR4), nem continuidade (MR1) entre as partes integrantes: introdução, desenvolvimento e 
conclusão. Além disso, a diferença de tamanho dos parágrafos é gritante. O que seria a introdução do texto é o parágrafo mais longo, seguido de dois parágrafos com apenas duas linhas.

Notamos falta de progressividade (MR2) em todo o texto, revelada, principalmente, pela desorganização textual. Não há, pois, equilíbrio entre continuidade temática e progressão semântica, sendo impossível reconhecer ordenação de causa-consequência entre argumentos expostos pelo produtor da redação.

O emprego de repetição lexical pode ser verificado através dos termos: "informação", "comunicação", "abusos" e "liberdade", o que mostra, novamente, o uso inadequado da MR1 (continuidade).

A superficialidade das informações denuncia a falta de conhecimento de mundo do autor e sua incapacidade em articular argumentos, pois o texto apresenta apenas ideias genéricas, como pode ser observado nos trechos:

"Os meios de comunicações sofrem também muitos abusos tanto pela sociedade, ou melhor pelo mundo todo".

"Só conseguiremos realmente liberdade as informações quando realmente o mundo melhorar com essa violência [...]”.

Tais comentários são passíveis de questionamento, o que compromete a aceitabilidade do texto, como também seu grau de informatividade, visto que são vazios de sentido.

Em suma, faltam pontos de vista mais elaborados e ideias adequadas ao real objetivo do texto.

\section{9-1}

\section{Mídia: o problema da comunicação}

Cada vez mais, cidadãos do mundo todo têm sua privacidade comprometida devido a escândalo causado pela mídia e pelos programas sensacionlaistas de TV. Populações humildes são invadidas e desreispeitadas, empresas de comunicação lucram devido os privilégios e, por causa disso, a mídia continua com seu péssimo desempenho.

Sabe-se que, hoje em dia, é muito comum ligar a televisão e deparar-se com uma família humilde que, desconhecendo qualquer lei que possa poupá-lo de uma vergonha, encontra-se invadido por câmeras, jornalistas e policiais, que tentam sugar toda e qualquer informação que possa atrair o público e envergonhar o entrevistado, que é tomado como vilão. 
É incontestável que, grandes empresas de comunicação desreispeitam as leis e ainda assim conseguem se beneficiar. Lucram devido ordens de seu representante, que está livre de qualquer processo, e que manda prosseguir, de qualquer maneira, para que assim possa enriquecer devido a ignorância não só das camadas baixas como de qualquer cidadão que desconhece seus direitos.

Nota-se que pequenos crimes são divulgados diariamente, enquanto os que são relevantes, são expostos de outra maneira para a população. Sem uma fiscalização eficiente, a mídia segue manipulando o povo, colocando uns contra os outros, enquanto ela usufriu de sua liberdade e ri das pessoas que são "contaminadas".

Então, conclui-se que a partir do momento que as pessoas não forem manipuladas, deixarão de ser desreispeitadas e julgadas pela mídia, que passará a ser significante para a sociedade, que só receberá a verdade acima de qualquer privilégio ou abuso, e usará desta como um modo para enriquecer seus conhecimentos e obter idéias e expressões próprias.

\section{ANÁLISE}

A produção textual inicia-se de maneira satisfatória e com progressividade (MR2), pois os recursos das MR1 (continuidade) e MR4 (articulação) são bem utilizados. No entanto, em alguns momentos, o leitor ainda sente a falta de conectores entre as frases.

O redator foge parcialmente ao tema proposto por não abordá-lo em sua plenitude, não focando o real objetivo do texto que é propor soluções de como evitar os abusos da mídia e garantir a liberdade de informação.

A linguagem utilizada é impessoal, sendo adequada à modalidade escrita dissertativoargumentativa. Assim, o texto está em equilíbrio ao conceito de situacionalidade por adaptarse à situação sociocomunicativa.

Assim sendo, verifica-se que o texto tem um bom padrão de coerência, mas peca, em determinados momentos, pela falta de conectivos, sendo necessária a adequação à MR4.

\section{4-5}

Para garantir a liberdade de informação e evitar abusos nos meios de comunicação, é preciso estabelecer limites. A mídia não pode invadir a privacidade das pessoas, e nem explorá-las. 
A imprensa não deve chegar nas casas das pessoas, com suas câmeras, filmando o que querem, sem ao menos pedir licença. Exploram essa gente, expondo suas vidas. Exibem essas informações que conseguiram nos jornais, nos programas de televisão, em rádios, e na maioria das vezes são fatos trágicos; filho que matou o pai, mãe que espancou o filho, garoto foi preso por envolvimento no tráfico e muitos outros.

Então, é preciso que haja limites. Informar sim, mas abusar das pessoas não. A imagem tem que ser preservada e a intimidade não pode ser violada.

Também é necessário que se crie leis, estabelecendo o direito das pessoas de terem sua honra preservada, sua moral não violada.

Concluindo, todos têm direitos: a imprensa, de informar, e as pessoas, de terem suas vidas preservadas.

\section{ANÁLISE}

Com base na leitura dessa redação é possível afirmar que o produtor apresenta dificuldades em desenvolver a estrutura de um texto dissertativo, visto que não produz suas etapas com eficiência (introdução, desenvolvimento e conclusão).

Há repetição da palavra "pessoas", o que denuncia a limitação de vocabulário do produtor do texto, sendo necessária adequação à MR1 (continuidade) e uso dos recursos de substituição, sinônimos e pronomes, por exemplo.

Além da repetição de palavras, há reiteração de ideias, o que fere o requisito de progressão (MR2), incorrendo no que Charolles chamou de "circularidade" do discurso:

"[...] A mídia não pode invadir a privacidade das pessoas [...]".

“A imprensa não deve chegar nas casas das pessoas [...] sem ao menos pedir licença $[\ldots] "$.

"a intimidade não pode ser violada [...]".

“Concluindo, todos têm direitos: a imprensa, de informar, e as pessoas, de terem suas vidas preservadas.".

A superficialidade das informações denuncia a falta de conhecimento do autor sobre o assunto e sua incapacidade em articular argumentos. Afirmações como: "Então, é preciso que haja limites. Informar sim, mas abusar das pessoas não. A imagem tem que ser preservada e a intimidade não pode ser violada", expõem apenas ideias genéricas e o redator não fornece sugestões, ao longo do texto, que exemplifiquem os tipos de limites. O autor repete que é necessário se estabelecer limites, mas não soluciona o problema em questão. 
De modo geral, falta em todo o texto consistência aos argumentos que são apresentados. Há, pois, necessidade de mais conectores (MR4), os quais estabeleceriam ligação entre as ideias expostas. Além disso, é preciso que se adapte a redação às MR1 e MR2.

Por fim, faltam pontos de vista mais elaborados e ideias adequadas ao real objetivo do texto. Além disso, é necessária a construção de um parágrafo conclusivo que contemple soluções à problemática exposta, mostrando o posicionamento crítico do redator.

\section{0-7}

A liberdade de imprensa e os abusos ocasionados pelo meio de comunicação são inseparáveis. Na verdade, um só existe a partir da existência do outro.

O direito de liberdade de informação da mídia é respeitado, ao contrário do direito de privacidade de todos os cidadãos.

Criar um órgão de controle à imprensa seria a atitude mais sensata a ser tomada, respeitando a sua liberdade, porém limitando a quando se exceder. Assim o abuso se tornaria escasso, mas, por outro lado, essa liberdade exgerada que é empregada a imprensa se limitaria, pois seria publicado apenas o que não desperta interesse nos leitores ou expectadores, tirando a maior característica da imprensa que é atender aos interesses desses que se saciam com a invasão de privacidade, enfim, com utilidades.

A empresa se controlada, certamente reivindicará por seus direitos e com o poder que possui seria difícil não retomar os seus abusos. Contudo, é melhor aceitar, conviver com esse desrespeito e torcer para que a próxima estampa, notícia não seja nem a sua família ou você.

\section{ANÁLISE}

Com base na leitura dessa redação, é possível afirmar que o produtor apresenta dificuldades em desenvolver a estrutura de um texto dissertativo, visto que não produz suas etapas com eficiência (introdução, desenvolvimento e conclusão).

Em todo o texto há argumentos sem fundamentação, os quais podem ser facilmente questionados pelo leitor, tais como: "A liberdade de imprensa e os abusos ocasionados pelo meio de comunicação são inseparáveis. Na verdade, um só existe a partir da existência do outro", do primeiro parágrafo e "Contudo, é melhor aceitar, conviver com esse desrespeito e 
torcer para que a próxima estampa, notícia não seja nem a sua família ou vocể, do quarto parágrafo. Esses comentários comprometem a aceitabilidade do texto, uma vez que o leitor pode refutar essas opiniões.

$\mathrm{O}$ autor não se posiciona criticamente sobre o tema. A superficialidade dos argumentos denuncia o seu conhecimento limitado sobre o assunto. O redator não é claro em sua argumentação, o que pode ser corroborado através da leitura do terceiro parágrafo, que é totalmente confuso e incoerente, infringindo a MR3 (não-contradição). Nesse momento, a credibilidade dos argumentos fica comprometida, pois o próprio emissor afirma algo que, mais a frente, refuta.

Por fim, a conclusão traz comentários sem fundamentação. Além disso, o autor não se posiciona criticamente nem fornece sugestões concretas para a resolução dos problemas, situação que destoa totalmente do que exige um texto dissertativo-argumentativo.

\section{0-1}

\section{Lucro, lucro e mais lucro}

A mídia é usada de forma abusiva, atende apenas, aos interesses de quem a comanda. A imprensa não precisa pedir "licença" para relatar os fatos, pois o poder que possui faz com o mundo se submeta a ela.

Aproveitando essa situação, este meio de comunicação, só divulga o que julga ser de desígnio de seus comandantes. Ouve-se falar, mas nunca se vê, o esforço por parte do jornalismo de transmitir, por exemplo, a morte de uma pessoa qualquer, porque não os traz lucro. Porém, se um bandido procurado é morto ou preso, todos os meios de transmissão divulgam a notícia, que consequentemente, trará dinheiro.

Pouco se vê sobre a fome, a miséria, o desemprego. Só em estatísticas. A vida das pessoas que sofrem com isso não é relatada. Pois é de maior interesse mostrar o que está ocorrendo de bom do que o que está acontecendo de ruim.

Portanto, ao invés da mídia ser usada como produto para atuar em prol de um serviço público, é utilizada apenas para atender aos lucros de uma poderosa maioria que a comanda.

\section{ANÁLISE}

Com base na leitura realizada, é possível afirmar que o autor da redação desconhece a estrutura e características dissertativas. É presente a fuga parcial ao tema, uma vez que a 
proposta temática não é contemplada em sua totalidade, fato que revela infração à MR4 (articulação). O autor aborda os abusos da mídia e não argumenta absolutamente nada sobre como garantir a liberdade de informação.

Os argumentos mostrados ao leitor são questionáveis, por não serem passíveis de comprovação. Esses comentários são mais influenciados pelo senso comum do que pela constatação do fato. Como pode ser observado no trecho a seguir: "Pouco se vê sobre a fome, a miséria, o desemprego. Só em estatísticas. A vida das pessoas que sofrem com isso não é relatada. Pois é de maior interesse mostrar o que está ocorrendo de bom do que o que está acontecendo de ruim.".

De modo geral, verificamos bom uso dos articuladores textuais "porém", "portanto", "pois", "porque" (MR4), o que confere ao texto um aspecto mais coeso. Além disso, a redação apresenta boa progressividade (MR2) e boa continuidade (MR1), mas os argumentos são superficiais e sem consistência.

A conclusão apresenta-se em um parágrafo muito curto, no qual não há argumentação. Observa-se apenas generalidade no que o autor sugere para acabar com os abusos da mídia, não havendo uma real criticidade. Com base nisso, a informatividade desse texto fica comprometida pela apresentação de argumentos que não expõem nenhuma informação nova ao leitor.

\section{5-3}

\section{Como garantir a liberdade de informação e evitar abusos nos meios de comunicação}

Hoje em dia nos não temos a liberdade que tinhamos, pois o mundo esta cada vez pior, é pai estrupando filhas, sequestros, roubos etc, em fim agente sai de casa sem saber se vai voltar.

Tem muitas pessoas disinformadas, mais com tanta violência agente não precisa nem de vêr jornais, televisão, ouvir rádios, ver revistas etc, que agente ver com nossos proprios olhos o que se passa no mundo.

Nos temos que fazer mais campanhas, palestras para evitar com essas barbaridades, vamos lutar contra isso para ter o mundo melhor, para gente e pros nossos filhos, não é esse mundo que nos queremos e sim um mundo de páz com muita segurança.

Vamos usar mais as televisões, os rádios e outras coisas para falar mais o que se passa no mundo, para tentarmos de uma forma ou de outra melhora o mundo em que nós vivemos. 


\begin{abstract}
ANÁLISE
O redator não apresenta as ideias de maneira clara e peca pelo falta de uso de recursos coesivos. O texto é muito carente de estrutura, necessitando de adequações à MR4 (articulação).

Notamos, em todo texto, a falta de progressividade (MR2), revelada, principalmente, pela carência de organização textual. Não há, pois, equilíbrio entre continuidade temática e progressão semântica, sendo impossível reconhecer ordenação de causa-consequência entre os argumentos expostos pelo produtor da redação.

A falta de articulação (MR4) e continuidade (MR1) entre as partes integrantes do texto é visível.

É nítida a dificuldade que o redator possui em utilizar, aceitavelmente, o código escrito, corroborada pelos desvios de estruturação formal da língua: ortografia, acentuação, pontuação, concordância verbal.

A linguagem utilizada é repleta de caráter pessoal, conforme os trechos:

"Hoje em dia nos não temos a liberdade que tinhamos [...] agente sai de casa sem saber se vai voltar."

“[...] agente não precisa nem de vêr jornais [...] que agente ver com nossos proprios olhos o que se passa no mundo”.

"Nos temos que fazer mais campanhas [...] vamos lutar contra isso [...] para gente e pros nossos filhos, não é esse mundo que nos queremos [...]”.

"Vamos usar mais as televisõe [...] para tentarmos de uma forma ou de outra melhora o mundo em que nós vivemos.".

No primeiro parágrafo, verificamos o emprego da expressão clicherizada "hoje em dia", o que denuncia falta de criatividade do autor ao iniciar sua redação.

A argumentação apresenta-se de maneira desorganizada, pois falta articulação entre as ideias expostas (MR4), revelada pela carência de recursos coesivos. A argumentatividade fica comprometida, visto que as sequências são desconexas e apresentam comentários que não contribuem para o desenvolvimento de um texto crítico e consciente.

Nota-se, também, que não há continuidade adequada (MR1), pois palavras são repetidas (“a gente”, por exemplo) e a dissertação fica empobrecida de recursos de retomada textual, tais como: sinônimos, pronomes ou advérbios. Tudo isso mostra o léxico limitado do
\end{abstract}


autor, o qual também não possui um conhecimento aprofundado do tema, fato confirmado pela superficialidade dos argumentos apresentados.

O autor não expõe nenhuma informação relevante, deixando a desejar no quesito informatividade. Ele apenas reproduz ideias muito genéricas, provenientes do senso comum, portanto, sem fundamentação.

Não foi realizada a conclusão, pois o que se tem no último parágrafo é um comentário que não demonstra posicionamento crítico do autor nem qualquer tipo de fundamentação lógica.

\section{3-1}

\section{O nível tem que subir}

A questão da mídia vem sendo muito discutida nos últimos anos, não há mais dúvidas sobre o grande poder pertencente a ela, a sua extrema capacidade de formar opiniões. A mídia é muito importante, por isso deve ser mais bem aproveitada, devem ser bem selecionados seus programas, não simplesmente jogar ao ar as notícias de acidentes, ou de pessoas famosas, isso não passa de uma apelação por audiência,

Certos canais costumavam usar e abusar de ploblemas sociais ou de até mesmo acidentes com mortes isso não chegaria a ser problema se o fato fosse mostrado de uma forma menos apelativa, sem sangue, sem imagens chocantes em horarios muito pouco apropriados. Leis deveriam ser criadas em uma tentativa de colocar aos jornalistas e responsáveis o peso de sua responsabilidade devido a sua importancia visando melhorar a qualidade do que é mandado para dentro das casas para toda a família.

É uma pena que muitas pessoas ainda gostem de simplesmente saber fofocar de famosos, ou ver mortes, isso deve-se a muitos anos de programas sem a menor qualidade sendo despejadas dentro das casas, de todas decidirem que isso tem que melhorar, com certeza irá acontecer, mas caso contrário o nível só continuará caindo, cada vez menos critérios.

\section{ANÁLISE}

Após a leitura do texto, é possível afirmar que o autor não expõe nenhuma informação relevante, afastando, destarte, o leitor, pois não traz informatividade ao texto. O produtor 
apenas reproduz ideias genéricas, provenientes do senso comum, portanto, sem fundamentação.

É presente a fuga parcial ao tema, uma vez que a proposta temática não é contemplada em sua totalidade, fato que revela infração à MR4 (articulação). O autor aborda os abusos da mídia e não constrói argumentos concretos sobre como garantir a liberdade de informação.

Os argumentos mostrados ao leitor são questionáveis, pois são comentários mais influenciados pelo senso comum do que pela constatação do fato. Isso pode ser observado no trecho a seguir: "É uma pena que muitas pessoas ainda gostem de simplesmente saber fofocar de famosos, ou ver mortes [...]". Comentários como esse tiram a credibilidade do texto, interferindo em sua aceitabilidade.

A conclusão, fornecida ao final do texto, é muito simplista, não fornecendo uma solução concreta para a problemática da proposta.

\section{6-3}

No intuito de encontrar um encaminhamento para resolver seus problemas, muitos buscam ajuda em emissoras de TV e RÁDIO. Algumas vezes encontram o que buscavam, outras vezes além de não solucionar seus problemas ainda são ridicularizados e sendo ainda motivo de risos.

Tem os casos em que jornalistas vão buscar em comunidades carentes quem é o pai do seu filho, ou até uma simples briga em boteco entre dois amigos que beberam de mais. Problemas que facilmente seriam resolvidos são transformados em espetáculo para trazer audiência à seus programas.

$\mathrm{Na}$ minha opinião esse e outros tipos de abuso seriam evitados, se a população soubesse de seus direitos e deveres. Se assim fosse a população saberia resolver seus problemas sem expor sua intimidade de tal maneira e os jornalistas não invadiriam a privacidade dessas pessoas.

\section{ANÁLISE}

Com base no texto lido, constata-se o emprego de repetição lexical, configurando infração à MR1. O emissor poderia ter utilizado outros recursos de retomada textual, os quais 
evitariam as repetições de termos, como "problemas" e "população". Tal fato evidencia falta de revisão, que causou a reiteração de tais palavras.

No segundo parágrafo não há clareza argumentativa, o que dificulta a compreensão da mensagem: "Tem os casos em que jornalistas vão buscar em comunidades carentes quem é o pai do seu filho [...]”.

Ao ler esse trecho, o leitor não compreende o motivo de os jornalistas irem às comunidades carentes para saber quem são os pais de seus filhos. Essa sequência ficou incoerente, prejudicando a progressividade do texto (MR2), necessitando, dessa maneira, de reformulação.

No terceiro parágrafo, notamos que a linguagem é utilizada com pessoalidade, como pode ser observado no trecho: "Na minha opinião esse e outros tipos de abuso seriam evitado [...]”.

Nota-se que, nesse momento, há desvio ao aspecto formal, requisito para o desenvolvimento de um texto dissertativo. A falta de adequação do texto à situação sociocomunicativa faz com que ele esteja em desequilíbrio com o conceito de situacionalidade.

A superficialidade das informações denuncia, também, o desconhecimento do autor sobre o assunto, porque ele expõe apenas ideias genéricas, as quais não contribuem em nada para a argumentatividade e são, desta forma, passíveis de questionamentos, o que compromete a aceitabilidade do texto.

O último parágrafo não expõe nenhuma solução concreta para a problemática da proposta, pois não há posicionamento crítico, nem fundamentação. O que se vê é um parágrafo vago de sentido, simplista, que apenas apresenta um comentário genérico. Esse fator leva ao total distanciamento do que se exige em um texto dissertativo.

\section{5-0}

O problema da mídia hoje em dia não é só no Brasil e sim no mundo todo. Ela invade nossas casas como quem não quer nada e somos incapazes de perceber.

A mídia só coloca no ar o que eles acham o que vai ser escândalo ou assunto no outro dia, como a guerra entre traficantes em favelas do rio, onde quem sai morto são os inocentes, mulheres siliconadas completamente nuas, políticos que roubam milhões e não são presos, pessoas que roubam $1 \mathrm{~kg}$ de arroz para alimentar a família e está sendo humilhado na cadeia. 
No mínimo eles teriam que ter consciência e saber quais os efeitos que essas imagens traz para nossas crianças. A televisão é muito carregada de programas banais, como esses de baixaria ao invés de mostrar coisas sadias como por exemplo a cultura de nosso país, coisas sobre o meio ambiente.

É isso que nossos olhos precisam ver, coisas alegre e não baixaria.

\section{ANÁLISE}

Essa redação apresenta inadequação vocabular, pois a linguagem com a qual o texto foi produzido não é condizente ao contexto de produção que exige uma variedade formal. Estão presentes, no texto, termos que não são coerentes à modalidade escrita dissertativoargumentativa, como: "baixaria" e "siliconadas".

A linguagem utilizada apresenta falta de formalidade. $\mathrm{O}$ autor faz abreviação de uma palavra ("kg", no segundo parágrafo), o que não está adequado ao contexto de produção em que o texto está inserido, configurando, portanto, um desacordo no quesito situacionalidade.

Ocorrem repetições de vocábulos em alguns momentos, como: "mídia" e "baixaria", evidenciando o vocabulário limitado do autor que, de maneira desequilibrada, fez uso da MR1, no que se refere à repetição, e não aproveitou a oportunidade para fazer a substituição do termo.

Além disso, a superficialidade das informações denuncia, também, a falta de conhecimento do autor sobre o assunto, pois o texto expõe apenas ideias genéricas, as quais não contribuem em nada. A exemplo, temos o trecho: "O problema da mídia hoje em dia não é só no Brasil e sim no mundo todo. Ela invade nossas casas como quem não quer nada e somos incapazes de perceber.".

Ao final do texto, constata-se que não é realizada a conclusão de maneira consistente, pois faltam ideias concretas, propostas conscientes que tentem fornecer uma resposta à temática em questão.

\section{3-0}

\section{Combate ao sensacionalismo}

A televisão tem como função transmitir aos telespectadores informações, entretenimento, entre outras finalidades, mas um tipo de programa que tem bastante audiência 
são esses que abusam e mostram os dramas da vida de vários brasileiros que passam dificuldades e esses pedem ajuda para as emissoras quem em troca entram e mostram para todo o país a vida dessas pessoas.

Em função disso é que se baseia muitos programas na televisão, apoiando para o pior e mostrando a desgraça da vida cotidiana das pessoas, tornando-os sem conteúdo. E ainda deixam de assistir jornais que trazem informações sobre o que está acontecendo no país só para assistir esse dramas pessoais.

Os programas sensacionalistas vem invadindo a televisão e ganhando cada vez mais espaço e para melhorar o conteúdo dos meios de comunicação e teriam que proibir esses tipos de programas mas isso seria uma censura à imprensa e correria o risco de haver uma proibição maior e prejudicar os meios informativos, podendo deixar muitos alienados sobre o que está acontecendo no mundo.

E ainda ganharia a insatisfação de muitos porque esses assistem esses programas se identificando com eles pois mostram problemas pessoais, dificuldades financeiras, etc. E isso ocorre bastante na vida de vários cidadãos brasileiros.

Portanto a maneira de fazer com que esses abusos não estejam mais presentes na mídia é organizando grupos que tenham como objetivos transmitir para todo o que o meio de comunicação tem de bom, como os jornais informativos e ainda muitos programas que em vez de serem apelativos e que abusam da vida das pessoas, transmitem e acrescentam cultura para nossa vida, e dessa maneira diminuiria o sensacionalismo e ainda não prejudicaria a liberdade de informação.

\section{ANÁLISE}

Verificamos, nessa redação, uma tentativa do autor em estruturar o texto de acordo com o gênero requerido, apesar das falhas e do conteúdo fraco.

Entretanto, notamos uma fuga parcial ao tema proposto, pois o autor não o aborda em sua plenitude, uma vez que discorre sobre os abusos cometidos pela mídia e não se atém ao real objetivo do texto, que é o de propor soluções para como evitar tais exageros e garantir a liberdade de expressão.

Após a leitura do texto, é possível afirmar que o redator faz uso eficiente de alguns conectores, como: "portanto" e "mas". No entanto, comete falhas com o uso desmedido da conjunção "e", comprovando-se, assim, infrações às metarregras 1 (continuidade) e 4 (articulação), como pode ser observado no terceiro parágrafo: 
Os programas sensacionalistas vem invadindo a televisão $\boldsymbol{e}$ ganhando cada vez mais espaço e para melhorar o conteúdo dos meios de comunicação e teriam que proibir esses tipos de programas mas isso seria uma censura à imprensa e correria o risco de haver uma proibição maior e prejudicar os meios informativos, podendo deixar muitos alienados sobre o que está acontecendo no mundo.

Desta forma, o texto precisa de convergência entre a MR1 e a MR4, de pontos de vista mais elaborados e de ideias adequadas ao real objetivo do texto. Além disso, é necessária a construção de um parágrafo conclusivo que contemple soluções à problemática exposta, mostrando o posicionamento crítico do redator.

\section{7-8}

\section{Fiscalização sem autoritarismo}

A imprensa tem um valor informativo inquestionável. Porém, atualmente, o abuso da liberdade de expressão vem gerando controvérsias e polêmicas.

Durante a ditadura militar brasileira, a censura chegou ao seu ápice. Jornalistas, artistas e até mesmo a população não possuíam direitos de reinvindicar ou manifestar-se contra medidas governamentais. Esse era um período de alienação, quando para se ter um governo forte era necessário o distanciamento entre governantes e governados.

Já hoje, vivemos numa democracia. A Constituição Federal evidencia a autonomia das empresas de comunicação desde que essas agissem de acordo com a ética, ou seja; sem intimidar ou violar a imagem das pessoas. Porém, esses deveres não vêm sendo cumpridos.

Por isso, organizações civis ou governamentais são bem vindas, somente se tiverem por objetivo a conscientização, fiscalizando os jornalistas, quanto ao enfoque de suas matérias, de acordo com os direitos civis. Além disso, deve haver a proteção e auxílio aos que tiveram sua vida privada e honra corrompidas. Recentemente, o governo Lula vem implementando uma agência reguladora do jornalismo, que ao primeiro instante é uma solução, porém excede o caráter regulador, podendo intervir na livre expressão da imprensa.

Conciliar ética no trabalho e liberdade de comunicação é um desafio. Por tudo isso, é necessário a atuação de todos, não só do governo, mas também dos cidadãos exigindo e fazendo valer seus direitos. 
O texto apresenta bom uso do requisito da MR1 (continuidade). Além disso, o redator demonstra ter conhecimento da estrutura dissertativa, conseguindo construir suas etapas (introdução/ desenvolvimento/ conclusão) com desenvoltura e eficiência.

A produção textual vai sendo apresentada de maneira satisfatória. A adequação ao recurso da MR4 (articulação) pode ser notada, quando o produtor faz uso de conectores que entrelaçam os argumentos, tais como: "por isso", "além disso", "recentemente" e "porém". O texto apresenta, também, boa progressividade (MR2), havendo equilíbrio entre continuidade temática e progressão semântica.

No terceiro parágrafo, o autor faz referência à Constituição Federal, o que configura o recurso da intertextualidade, aumentando, destarte, o teor informativo do texto. O redator discorre de maneira clara, conseguindo fazer relações coerentes que só aumentam a qualidade de seus argumentos e, por consequência, seu poder de persuasão.

Assim sendo, verifica-se que o texto tem um bom padrão de coerência, estando de acordo com as metarregras propostas por Charolles.

\section{3-2}

\section{Liberdade jogada no lixo}

Ao longo dos anos, é visível a decadência dos meios de comunicação nacionais. Atualmente, a qualidade de documentários, jornais e programas em geral é lamentável. E com certeza a mídia é o ramo da comunicação que mais tem deixado a desejar. Programas sem conteúdo, que só mostram desgraças ou que fazem fofoca sobre a vida de alguém são os únicos assuntos abordados por esse meio.

Não sendo isso o suficiente, é espantoso como o respeito também diminuiu nesse tempo, jornalistas invadem propriedades restritas, incremetam histórias a fim de torná-las mais interessantes... Mas, o que está ficando desapercebido, é que atitudes assim apenas desqualificam seus trabalhos.

O que deveria ser sério, está banal, o que deveria ter cunho moralizante ou reflexivo, se apresenta de forma sensacionalista e ridícula! Então, o que fazer para que a liberdade de informação seja garantida sem que ocorram abusos por parte daqueles que informam? 
É simples, basta que apresentem a verdade, despida de excessos e mentiras. A verdade, certamente acarretará sucesso, reconhecimento, mas a cima de tudo a qualidade de um trabalho.

Com isso, fica fácil perceber que a seriedade no qual fazemos um trabalho e o respeito que é dado à ele, é que garantem seu sucesso. Para dar uma boa informação, basta retratar a verdade!!!

\section{ANÁLISE}

A argumentatividade fica comprometida, visto que as sequências textuais apresentam comentários que não contribuem para o desenvolvimento de um texto crítico e consciente, tais como: "Programas sem conteúdo, que só mostram desgraças ou que fazem fofoca sobre a vida de alguém são os únicos assuntos abordados por esse meio”.

O argumento é totalmente questionável, o que reduz a credibilidade do texto, diminuindo, também, sua aceitabilidade pelo leitor.

Há repetição de palavras de maneira automática, o que denuncia a limitação de vocabulário do produtor do texto. Os vocábulos "verdade", "comunicação", "sucesso" e "trabalho" são reiterados, algumas vezes, demonstrando o uso desequilibrado da MR1 (continuidade), ao passo que a substituição lexical seria mais coerente.

A linguagem, em várias passagens, não apresenta formalidade, requisito básico para o desenvolvimento de um texto dissertativo. A exemplo, temos os termos: "ridícula" e "fofoca". A falta de adequação do texto à situação sociocomunicativa faz com que ele esteja em desequilíbrio ao conceito de situacionalidade.

$\mathrm{Na}$ conclusão, a proposta feita é simplista, apenas refletindo o senso comum. O redator não traz nenhuma sugestão concreta que possa servir de solução para o problema proposto pelo tema.

\section{9-0}

\section{Liberdade sem abusos}

Nesse tempo contemporâneo, a censura é quase imperceptível, inabitável. Onde estão os bons programas de televisão? No lugar destes, estão aqueles de baixo escalão, onde ao invés de um decente desfile de modas, aparecem mulheres exibindo seus "peitos e bundas", 
que ao contrário de educar, ensinam como funciona o tráfico ou como manipular uma arma. A busca de ibope, de lucratividade, faz com que os programas assumem um valor pejorativo, diminuindo o nível cultural da população como um todo, pois os meios comunicativos são os formadores de opinião.

De fato dá-se liberdade em demasia para os meios comunicativos. Um modo de retrair essa expansão descontrolada, pode ser feita através de incentivos à produções educativas e instrutivas, com a abertura das vias comunicativas a todo país e reduzindo o custo das produções. A chegada desses programas a todos os cantos do país ampliará o potêncial de cultura do povo, gerará ibope e com isso lucratividade aos produtores.

Em 1994, o [poder do povo] conseguiu derrubar o presidente da República. Em pleno século vinte e um, esse mesmo povo tem sua força aumentada através das leis e direitos da Constituição Federal. Pelo conhecimento dessas leis a população juntamente com o Estado podem derrubar programas que estejam ferindo a ética e a moral. Assim, por meios legais é possível evitar os abusos dos meios comunicativos.

Apesar da censura não ser devidamente respeitada, pode se observar esse fato por meio dos programas apelativos transmitidos na televisão brasileira, existem além de por leis, formas que vão de incentivos estatais ao bom censo para se ter uma liberdade sem abusos nos meios comunicativos.

\section{ANÁLISE}

O produtor dessa redação demonstra conhecimento da estrutura dissertativa, conseguindo construir e delimitar suas etapas (introdução/ desenvolvimento/ conclusão) de maneira coerente.

Em alguns momentos, o texto apresenta inadequação vocabular, pois a linguagem não é condizente ao contexto de produção, o qual exige uma variedade formal. Termos pejorativos como "peitos" e "bundas" são utilizados, dando um aspecto informal à redação, fato que a deixa em desacordo com o quesito situacionalidade.

Há repetição lexical dos termos "meios comunicativos" e "programas", o que mostra o uso inadequado da MR1 (continuidade). No caso dessa dissertação, o ideal seria utilizar os recursos de substituição, através de sinônimos e pronomes.

Em suma, verificamos que o texto tem um padrão de coerência razoável, mas falha por fugir quase que totalmente ao tema, uma vez que foca a qualidade dos programas de televisão e não fornece medidas efetivas que combatam os abusos e garantam a liberdade de 
informação. Além disso, apresenta uma linguagem desapropriada, diminuindo a credibilidade do argumento.

1132922-0

\section{O poder de invasão}

Uma notícia, um anúncio, uma reportagem, uma entrevista, são atos de comunicação, onde você tem como objetivo informar um receptor. Procura atingir as classes e religiões das mais variadas. A comunicação não tem limites de imagens, privacidade e crítica.

A mídia, como maior fonte de comunicação, tem o poder de persuadir as pessoas essas não obterem muitos conhecimentos em relação as camadas mais favorecidas. Com isso, muitos desses desinformados acabam se alienando por programações fúteis e não instrutivas. Essa é a realidade da maior parte da população mundial.

A televisão, por exemplo, consegue penetrar na vida íntima das pessoas e revelar o que, na verdade, não interessa a ninguém. O único objetivo é ganhar dinheiro com a audiência.

Porque a mídia não usa essa fonte para educar, mostrar um caminho bom para se viver? Enfim, mudar. Devia ser criado um orgão governamental, ou não, onde regras de censurar serão impostas.

\footnotetext{
ANÁLISE

Nesse texto, presenciamos argumentos sem fundamentação, os quais podem ser facilmente questionados pelo leitor: "Com isso, muitos desses desinformados acabam se alienando por programações fúteis e não instrutivas. Essa é a realidade da maior parte da população mundial.". O receptor do texto fica sem saber de onde o emissor retirou tal informação e esse tipo de comentário, refletor do senso comum, compromete demasiadamente a aceitabilidade do texto, visto que o leitor pode refutar essas ideias.

A respeito da MR1, pode-se dizer que não há uma continuidade adequada (MR1), tendo em vista a não existência da repetição lexical.

Há, também, trechos confusos, os quais comprometem a coerência do texto (MR3), como pode ser observado no terceiro parágrafo: "A televisão, por exemplo, consegue penetrar
} 
na vida íntima das pessoas e revelar o que, na verdade, não interessa a ninguém. O único objetivo é ganhar dinheiro com a audiência.".

O fragmento apresentado é incoerente, pois se a televisão expõe algo que não interessa a ninguém, como um programa desse tipo conseguiria audiência? São ideias contraditórias.

Ainda sobre a infração à MR3 (não-contradição), observa-se um desequilíbrio no parágrafo destinado à conclusão, quando o autor utiliza o conectivo "ou não", haja vista que o termo torna o período confuso: "Porque a mídia não usa essa fonte para educar, mostrar um caminho bom para se viver? Enfim, mudar. Devia ser criado um orgão governamental, ou não, onde regras de censurar serão impostas.".

Todos esses fatores interferem na argumentatividade, a qual não convence o leitor devido à falta de embasamento e profundidade dos comentários apresentados.

\section{9-1}

\section{Morais Comuns}

Sabe-se que a constituição afirma a liberdade de imprensa e a privacidade do cidadão. O problema a ser combatido é: como associar estas leis sem que haja prejuízo para qualquer dos lados.

O que mais se vê na televisão de canais abertos, principalmente, são programas que fazem de suas vidas jornalísticas perseguidores da vida íntima de pessoas que mostrem algum interesse para a população. Essas pessoas, mais conhecidas como "celebridades", precisam andar nas ruas disfarçadas e em constante fuga dos "paparazzi”.

Portanto, como é possível relacionar estes dois tipos de vida, que vivem conflitando, e até atropelando uns aos outros? Os programas de fofoca, não se sustentam sem as fofocas, e as "celebridades" vêem suas vidas atribuladas por conta da falta de privacidade que esses "paparazzi” lhes proporcionam. Os "paparazzi” não vivem sem as "celebridades", e essas só vivem sem eles. O que fazer?

$\mathrm{Na}$ visão daqueles que possuem um pouco mais de instruição cultural, os programas de fofoca são o que há de pior na TV aberta. O comportamento desses programas seria considerado imoral se fosse levado ao convívio social. É aí que se bate de frente com a liberdade de imprensa e até com o bom senso. Como pode uma emissora se sustentar se ela não alcança o interesse do seu telespectador, que por sua vez, por problemas econômicosociais só possui nível intelectual para assistir programas de fofoca. Ou será que os programas 
de fofoca mecanismos para desviar a mente do telespectador dos reais problemas do seu cotidiano?

Até aqui, pode-se ver uma lista de prós e contras, a privacidade contra a liberdade de imprensa. Vê-se também que a batalha foi perdida pelos "paparazzi”. A melhor maneira é mesmo a moralidade em prol da privacidade. Que a imprensa encontre meios que não prejudique os outros, que não invada as suas privacidades pois quem mais perde, é ele mesmo!

\section{ANÁLISE}

Essa dissertação foge quase que totalmente ao tema proposto, uma vez que o autor atém-se ao universo das pessoas famosas e não fornece soluções para evitar os exageros da mídia e garantir a liberdade de informação.

Ocorrem repetições de vocábulos em vários momentos, com destaque para “celebridades", "fofoca" e "paparazzi”, termos utilizados várias vezes no texto. Isso evidencia o vocabulário limitado do autor que, de maneira desequilibrada, faz uso da MR1 (continuidade), não aproveitando a oportunidade para fazer a substituição dos termos.

Em vários momentos, encontramos lacunas textuais que interferem na compreensão da mensagem que se deseja transmitir. Essas lacunas também estão relacionadas à MR1 (continuidade), nos momentos em que são utilizados recursos de retomada textual, mas não são expostos os referentes, impossibilitando o leitor de fazer recuperação destes. Isso acontece no último parágrafo:

“A melhor maneira é mesmo a moralidade em prol da privacidade. Que a imprensa encontre meios que não prejudique os outros, que não invada as suas privacidades pois quem mais perde, é ele mesmo".

O autor não deixa explícito a quem se refere ao usar o pronome "ele", não possibilitando ao leitor fazer a compreensão real da mensagem.

A superficialidade das informações denuncia a falta de conhecimento do autor sobre o assunto e sua incapacidade em articular argumentos. Afirmações como: "Na visão daqueles que possuem um pouco mais de instruição cultural, os programas de fofoca são o que há de pior na TV aberta." expõem apenas ideias genéricas que refletem o senso comum, sendo, portanto, passíveis de questionamento pelo leitor.

Por fim, a conclusão é desenvolvida de maneira simplista, não mostrando argumentação nem criticidade por parte do produtor do texto. 


\section{0-5}

\section{Como garantir a liberdade de informação e evitar os abusos nos meios de comunicação?}

A varias formas de garantir a liberdade de informação e evitar os abusos nos meios de comunicação. Dentre eles estão esses:

Lendo jornais e revistas, vendo programas que nos mostram o dia-a-dia e a convivência com os parentes e vizinhos.

Quando você lê os jornais consegue ficar sabendo do que está acontecendo no seu país e até no mundo, porque o jornal nos traz informações juntamente com as revistas e os noticiarios da TV é também o meio mais fácil conversar com o vizinho que vai dizer o que aconteceu quando você não estava nomento é poderá aconselha-la.

Dessa forma conseguiremos evitar os abusos em meio a informação pois se nos garantirmos e previnirmos não sofreremos abusos por partes do meio da comunicação principalmente o que se estabelece as atitudes e atos de amigos, desconhecidos primos e irmãos.

Comunicação um grande passo para uma nova geração para um povo esforçado a procura de melhorar para nossas vidas nesse e em um novo governo brasileiro.

\footnotetext{
ANÁLISE

O autor não apresenta conhecimento de estrutura dissertativa, uma vez que não reconhece o tema como proposta para o desenvolvimento de seu texto, tratando-o como uma simples pergunta, o que pode ser verificado no primeiro parágrafo: "A varias formas de garantir a liberdade de informação e evitar os abusos nos meios de comunicação. Dentre eles estão esses:".

É preciso enfatizar que houve confusão por parte do emissor entre tema e título, uma vez que se repete a proposta no campo para o qual se destina o título da redação.

Além disso, o texto apresenta necessidade de adequação à MR4 (articulação), pois, em alguns momentos, faltam conectores, os quais deixariam a estrutura textual mais coesa e garantiria articulação entre os argumentos propostos.
} 
A progressividade do texto, MR2, fica comprometida, principalmente no segundo parágrafo, pois o leitor não compreende a relação entre os argumentos expostos. Percebe-se, dessa maneira, desequilíbrio entre continuidade temática e progressão semântica.

A superficialidade das informações denuncia a falta de conhecimento do autor sobre o assunto e sua incapacidade em articular argumentos plausíveis, fato que prejudica toda a argumentatividade do texto, por não possuir poder persuasivo. Observemos o seguinte trecho:

"Quando você lê os jornais consegue ficar sabendo do que está acontecendo no seu país e até no mundo."

O que o emissor fez nesse excerto foi apenas apresentar uma concepção genérica, a qual reflete o senso comum, sendo, portanto, passível de questionamento. Afirmações vagas de sentido, como as apresentadas, não contribuem em nada para a informatividade do texto.

No último parágrafo, notamos que o emissor utiliza o termo "comunicação" para se referir aos meios de comunicação de massa, como televisão e rádio. Entretanto, nota-se que a tentativa de substituição não foi bem-sucedida, uma vez que a palavra "comunicação" é muito mais abrangente por abarcar todos os processos comunicativos que utilizam as linguagens verbal e não-verbal. Assim, a tentativa de substituição (MR1-continuidade) não foi realizada de maneira adequada.

Em suma, faltam pontos de vista mais elaborados e ideias adequadas ao real objetivo do texto. Além disso, é necessária a construção de um parágrafo conclusivo que contemple soluções à problemática exposta, mostrando o posicionamento crítico do redator.

\section{3-7}

\section{A liberdade e os abusos dos meios de comunicação}

Durante a ditadura militar, os meios de comunicação foram censurados, e durante muito tempo a população não teve conhecimento do que acontecia realmente no país. Com o fim da ditadura, a censura foi superada e hoje as leis que garantem a liberdade de imprensa são rigidamente seguidas. Porém, é cada vez mais comum a exibição de programas sensacionalistas, que mostram problemas familiares e escândalos, ferindo a moral dessas pessoas e a constituição. Até que ponto essa liberdade é positiva? Como regular a imprensa sem censurar?

Há muitos processos de danos morais por parte da imprensa em andamento e a maioria demora anos até um desfecho. Cabe ao governo formar órgãos especiais para cuidar desses 
casos, acelerando o processo e intimidando emissoras a ter mais cuidado com o que exibem compete também ao estado fiscalizar, para impedir que as emissoras transmitam programas de conteúdo apelativo em horário inadequado. Mas não apenas o governo deve atuar, os meios de comunicação têm a maior carga de responsabilidade:

Deve-se formar uma comissão ética, que inclua todos os grupos televisivos, visando estipular parâmetros para a programação, e horários limites para a mesma. Desse modo, programas sensacionalistas e jornalísticos sórdidos poderiam até existir, mas com o aval dos envolvidos e em horário adequado.

A partir do momento em que houver órgãos de fiscalização e as emissoras tiverem responsabilidade social, os abusos dos meios de comunicação irão diminuir e sem ferir a liberdade de imprensa, que é fundamental.

\begin{abstract}
ANÁLISE
O autor demonstra conhecimento da estrutura dissertativa, conseguindo construir suas etapas (introdução/ desenvolvimento/ conclusão) com desenvoltura e eficiência.

A linguagem utilizada é impessoal, sendo adequada à modalidade escrita dissertativoargumentativa. Assim, a adequação do texto à situação sociocomunicativa o deixa em equilíbrio com o conceito de situacionalidade.

O texto apresenta, também, boa progressividade (MR2), havendo, pois, equilíbrio entre continuidade temática e progressão semântica.

Além disso, a redação apresenta, positivamente, o recurso da MR1 (continuidade). Apesar de haver repetição lexical no decorrer da redação, a reiteração não prejudica a argumentação exposta.

A produção apresenta, também, adequação à MR4 (articulação), havendo presença dos conectores "porém", "mas", "desse modo", os quais deixam a estrutura textual mais coesa e garantem articulação entre os argumentos propostos.

Assim sendo, verificamos que o texto tem bom padrão de coerência, expondo os argumentos com clareza ao leitor, conseguindo, portanto, discorrer sobre o tema proposto com serenidade e consciência.
\end{abstract}

1132979-3

\title{
Manipulação da informação
}


A mídia nacional tem extrapolado em seus comentários e imagens, ocasionando constrangimento para muitas pessoas públicas. Os meios de comunicação estão perdendo a sua função primordial de transmitir informação verdadeira e vital para a população. No entanto, a interferência brutal do governo na mídia, seria uma forma de manipulação dos ideais da liderança política de um determinado mandato.

O governo atual vem tentando uma regulação da mídia, através de modificações de leis e criação de novas entidades que controlem melhor os meios de comunicação, como a proposta da Ancinav que fiscalizaria a parte de áudio-visual. Porém a Ancinav foi vista por muitos como forma de opressão e censura, sendo muito criticada por profissionais da área de comunicação.

A liberdade de expressão é um dos direitos nacionais mais recente, devido ao grande período de ditadura militar (1964-1985). Essa liberdade foi muito sofrida e custosa, então restringi-la ou deposita-la nas mãos de uma entidade é angustiante.

As indenizações que são pagas pela mídia quando há intervensões na vida privada, honra e imagem das pessoas, já agem como meio retardatário de programas ou reportagens de má índole, apesar de serem insuficientes para a solução do problema.

Portanto, é necessário que haja liberdade parcial, onde não apareça formas de repressão, mas ao mesmo tempo desistimule os meios de comunicação de publicarem reportagens mentirosas, através de multas aplicadas a essas entidades.

\footnotetext{
ANÁLISE

Com a leitura da redação, é possível afirmar que o produtor demonstra conhecimento da estrutura do texto dissertativo, conseguindo construir suas etapas (introdução/ desenvolvimento/ conclusão) com serenidade.

A linguagem utilizada é impessoal, sendo adequada à modalidade escrita dissertativoargumentativa. Assim, a adequação do texto à situação sociocomunicativa o equilibra ao conceito de situacionalidade que postula Beaugrand \& Dressler (fatores de textualidade).

O texto apresenta boa progressividade (MR2), havendo equilíbrio entre continuidade temática e progressão semântica. Além disso, apresenta bom uso da MR1 (continuidade). Apesar de haver repetição lexical no decorrer da redação, a reiteração não prejudica a argumentação exposta.
} 
Essa dissertação apresenta, também, adequação à MR4 (articulação), havendo a presença de conectivos, os quais deixam a estrutura textual mais coesa e garante articulação entre os argumentos propostos.

No terceiro parágrafo, o autor faz referência ao período da ditadura militar, configurando o recurso da intertextualidade. $\mathrm{O}$ redator discorre de maneira clara, conseguindo fazer relações coerentes que só aumentam a qualidade de seus argumentos e, por consequência, seu poder de persuasão.

Assim sendo, verificamos que o texto tem bom padrão de coerência, já que expõe os argumentos com lucidez, conseguindo, portanto, discorrer sobre o tema proposto com consciência.

\section{5-5}

\section{Manipulação}

Chega a ser cômico a maneira com a qual a mídia lida com o jeito de pensar das pessoas, ela entra e faz da cabeça da população o que bem entende, sem pedir licença ou permissão. Por que será que ela tem este dom? ou melhor, porque as pessoas se deixam levar tão fácil?

A sociedade tenta se manter informada, só que de maneiras bem distintas. Uma parte procura se manter informada do que esta acontecendo no mundo, o país, na sociedade como um todo, mas existe também aquela outra parcela que se preocupa com a sociedade sim, mas com casos bem específicos, como: quem matou, quem morreu, quem casou, quem se divorciou melhor dizendo fofocas.

Todavia a imprensa tenta atender a todos, sem uma gotícula apenas de discriminação, ela manterá informado quem deseja se informar. Só que às vezes por tentar ser tão eficaz ela acaba passando por cima dos abordados, sem nenhuma piedade, mostrando a sociedade a que ela quer.

Portanto a mídia tem como todos seus prós e contras, mantém a todos muito bem informados do que esta acontecendo no mundo, no país ou na esquina, mas também informa a todo mundo o que esta acontecendo aí, bem na sua casa. Então devemos sim, ler o que a imprensa nos transmite, porém não acreditar em tudo. Porque ela mostra a notícia de um modo que venda mais. 


\begin{abstract}
ANÁLISE
O autor conhece a estrutura de um texto dissertativo, pois desenvolve a redação com certa organização, apresentando linearidade nas partes integrantes: introdução, desenvolvimento e conclusão.

No entanto, a linguagem utilizada é inadequada por não possuir formalidade, característica básica do texto argumentativo:

“Chega a ser cômico a maneira com a qual a mídia [...]”.

"[...] mas com casos bem específicos, como: quem matou, quem morreu, quem casou, quem se divorciou melhor dizendo fofocas.".

Assim, a falta de adequação do texto à situação sociocomunicativa faz com que ele esteja em desequilíbrio ao conceito de situacionalidade.

A oralidade está, também, presente através do uso de gírias, como no trecho: “[...] ela entra e faz da cabeça da população [...]”.

Tal variedade é típica da fala e não da escrita, conferindo ao texto um caráter informal, o que não deveria acontecer.

De modo geral, o produtor faz bom uso da MR4 (articulação), possibilitando a conexão entre os parágrafos e argumentos. Percebe-se que no decorrer da redação são utilizados conectores, como: “então", "mas" e "portanto".

Em alguns momentos, o emissor poderia ter efetuado a retomada de alguns termos de outra forma que não fosse a repetição (MR1). Através do uso de pronominalização e sinônimos, por exemplo, seria possível evitar a reiteração desnecessária, como no caso do pronome "ela".

Em síntese, o texto analisado possui bom padrão de coerência, no entanto, necessita de adequação na linguagem, visando conferir mais formalidade e credibilidade aos argumentos apresentados, além de reestruturação no que compete à MR1 (continuação).
\end{abstract}

\title{
1132999-8
}

\section{Brasil, um país de todos?}

Nosso país é muito injusto. Todos os interesses giram em mãos de poucos, que saciam suas necessidades tirando o que há de mais triste nos cidadãos humildes. Esses, com poucas 
instruções, na maioria das vêzes, não sabem direito o que se passa, e por conseqüência disso, ficam muito expostos as críticas do povo.

Os meios de comunicação de massa, estão em contato com uma enorme parcela da população, que na verdade atendem apenas a um número restrito de acionistas e representantes. Mas, por esse e outros motivos, a mídia continua atuando de forma ilegal e injusta.

Esse problema deveria ser solucionado o mais rápido possível, para que acabe logo com essa grande injustiça com os menos favorecidos. Por início, as empresas deveriam ser mais cuidadosas com seu povo, não os expondo a grandes humilhações. São pessoas inocentes que não sabem que estão sendo filmadas. Os jornalistas podem ter mais responsabilidades também, enviando invasão de privacidade.

Os países de primeiro mundo como a Grã-Bretanha e a Suécia, vem há anos tentando solucionar o problema da regulação da mídia em seus países. Isso serve de exemplo para o Brasil fazer o mesmo. Mas, aqui existe o Observatório da Imprensa, que visa regular o desempenho da mídia brasileira. Como que com todas essas organizações contra o abuso do poder da mídia, o Brasil ainda comete injustiça com suas propagandas?

A resposta é simples, muitos com pouco e poucos com muito, ou seja, a pequena parte que têm muito dinheiro, tem o controle sobre os meios de comunicação de massa, cujas decisões estão de acordo com seus interesses e assim excluindo grande parte da população.

\section{ANÁLISE}

Esta produção textual inicia-se de maneira satisfatória e com progressividade.

Analisada globalmente, podemos dizer que a redação apresenta, coerentemente, o recurso da MR4 (articulação), pois o autor utiliza conectores como "mas", "ou seja", "assim" e "por conseqüência disso".

Percebemos que a dissertação não possui grandes problemas em relação à MR1 (continuidade), entretanto, o produtor poderia ter utilizado essa metarregra de uma forma mais eficiente, fazendo a retomada de termos através de sinônimos, pronomes etc, evitando, desse modo, a repetição lexical. Isso acontece, por exemplo, com o vocábulo "mídia”.

Além disso, há outros trechos que são muitos genéricos de sentido, passíveis de questionamento, como pode ser observado no excerto:

"Nosso país é muito injusto. Todos os interesses giram em mãos de poucos que saciam suas necessidades tirando o que há de mais triste nos cidadãos humildes.”. 
Argumentos desse tipo não trazem nada de novo ao leitor, sendo, dessa maneira, apenas reprodutores do senso comum.

O emissor apresenta argumentos superficiais que denunciam o seu conhecimento limitado sobre o assunto. $\mathrm{O}$ autor se prende muito aos exageros cometidos pela mídia e não discorre a respeito da liberdade de informação, que também deve ser abordada no desenvolvimento do texto. Por isso, o produtor foge parcialmente ao tema ao não contemplálo em sua totalidade.

A linguagem utilizada é impessoal, sendo adequada à modalidade de escrita dissertativo-argumentativa. Assim, a adequação do texto à situação sociocomunicativa faz com que ele esteja em equilíbrio ao conceito de situacionalidade.

Em suma, o último parágrafo não expõe nenhuma solução para a problemática proposta, pois não há posicionamento crítico do autor. Na realidade, não existe um parágrafo que faça o fechamento da ideias, o que dá a sensação de o texto estar incompleto.

\section{6-1}

\section{Educando para mudar o final do filme}

Meios de comunicação, trata-se das diversas maneiras que o homem utiliza para trocar informações. Na aldeia global que é o século XXI os meios de comunicações são postos em evidência, à medida que a expansão de mercados e a idéia de mundo globalizado fez crescer a necessidade de utilização dos veículos informacionais. Não é diferente no Brasil onde a televisão torna-se o protagonista dessa trama trabalhando em um grande filme nacional chamado "Abuso do poder moderno".

No Brasil a liberdade de expressão artística e o fim da censura, resultados de muita luta contra um governo ditatorial e bárbaro, são direitos protegidos por lei. Presentes na constituição de 1988, esses direitos vem sendo utilizados como uma importante arma pela imprensa, que além de apresentar todo um lado positivo informacional de total necessidade para o país, aproveita desse benefício para também mostrar conteúdos maliciosos, para um povo ainda subdesenvolvido de educação precária com objetivo de alienar cada vez mais um povo já alienado.

Em décadas passadas, o Brasil passou por um modelo de governo muito cruel, a Ditadura. Nesses tempos o Estado tinha total controle sobre a imprensa e os meios de comunicação e o direito ao Hábeas Corpus fora suspendido, esse dentre outros fatores tornou o período alvo de inúmeros conflitos. Naquela época a população encontrava-se em sua maior 
parte engajada e totalmente a par da situação. Diferentemente de hoje em que a nossa nação passa por sérios problemas e a mídia ao invés de honrar a árdua vitória do fim da censura, acaba sendo a grande responsável pela alienação do povo, passando programas totalmente "industrializados" com pouca ou sem nenhum fim social.

Portanto, enquanto muitos criticam um dos atuais projetos de nosso excelentíssimo presidente Lula que pretende de uma forma geral censurar um pouco mais a mídia, deveríamos pensar que mesmo não sento tão positiva e progressista o projeto pode se tratar mesmo que de forma infeliz de uma primeira tentativa de amenizar o abuso de poder dos meios de comunicação. De forma alguma o direito a liberdade de informação deve se atingido, o principal problema aliás a base de todos os problemas de nosso povo está na educação. Só educando a população e dando condições dignas para sua criação a sociedade brasileira irá aprender a filtrar o necessário das informações recebidas, só educando a população poderemos por um fim bem interessante para o "abuso de poder moderno" em que o protagonista perca toda sua força para o seu "vilão" o povo.

\section{ANÁLISE}

Esta produção textual inicia-se com erros de concordância, mas de maneira satisfatória e com progressividade, por ter sido criado um contexto para a discussão das ideias que serão apresentadas. Embora a ênfase para a discussão acerca do papel dos meios de comunicação na sociedade recaia sobre a televisão, essa delimitação é justificada pelo fato de ser considerado meio mais significativo na sociedade.

O texto anterior é um exemplo do uso correto, na maior parte do tempo, dos requisitos de coerência, pois entendemos o posicionamento do autor, isto é, quase não há problemas com relação à decodificação textual.

A boa estruturação é resultado da articulação das ideias e partes do texto (MR4). No segundo parágrafo, verificamos que há um objetivo determinado pelo aluno: falar sobre a liberdade de expressão e dos abusos promovidos por alguns meios de comunicação. O terceiro parágrafo faz uso de referências históricas para justificar a importância que a liberdade de expressão tem em nosso país, mas também aponta a falta de compromisso político que a imprensa demonstra hoje diante dos problemas sociais vigentes. Isso servirá de justificativa para a defesa que vem a seguir: pelo projeto de lei governamental seria possível controlar algumas informações que não estivessem a serviço da sociedade como um todo. 
A metarregra de repetição (MR1) é usada para caracterizar a manutenção temática. Termos e expressões que fazem parte do desenvolvimento do assunto naturalmente se repetem, sem prejuízo ao texto.

A progressão (MR2) encontra-se bem trabalhada, pois as ideias são apresentadas, justificadas e retomadas para estar vinculadas às ideias seguintes. O segundo parágrafo, por exemplo, inicia informando que "No Brasil a liberdade de expressão artística e o fim da censura, resultados de muita luta contra um governo ditatorial e bárbaro, são direitos protegidos por lei.", na sequência, o assunto é retomado adequadamente por meio de pronomes e nomes: "Presentes na constituição de 1988, esses direitos vem sendo utilizados como uma importante arma pela imprensa [...]". Esse procedimento também ocorre no terceiro parágrafo pelas expressões "nesses tempos" e "naquela época".

Temos, pois, no que diz respeito à coerência, um texto bem construído. É evidente que não se trata de uma produção perfeita, mas revela um considerável poder de articulação lógica do pensamento e de uso dos conteúdos estudados nas aulas de História. 